\title{
Never Versus Ever Feeding Human Milk and Food Allergies, Allergic Rhinitis, Atopic Dermatitis, and Asthma: A Systematic Review
}

The Pregnancy and Birth to 24 Months Project

Published date: April 15, 2019

Nutrition Evidence Systematic Review

Center for Nutrition Policy and Promotion

Food and Nutrition Service

U.S. Department of Agriculture

3101 Park Center Drive

Alexandria, Virginia 
This systematic review was conducted for the Pregnancy and Birth to 24 Months Project (P/B-24 Project) by the Nutrition Evidence Systematic Review (NESR) team at the Center for Nutrition Policy and Promotion, Food and Nutrition Service, USDA. All systematic reviews from the P/B-24 Project are available on the NESR website: https://nesr.usda.gov.

Conclusion statements drawn as part of this systematic review describe the state of science related to the specific question examined. Conclusion statements do not draw implications, and should not be interpreted as dietary guidance.

The contents of this document may be used and reprinted without permission. Endorsements by NESR, the Center for Nutrition Policy and Promotion, the Food and Nutrition Service, or the U.S. Department of Agriculture (USDA) of derivative products developed from this work may not be stated or implied.

In accordance with Federal civil rights law and USDA civil rights regulations and policies, the USDA, its Agencies, offices, and employees, and institutions participating in or administering USDA programs are prohibited from discriminating based on race, color, national origin, religion, sex, gender identity (including gender expression), sexual orientation, disability, age, marital status, family/parental status, income derived from a public assistance program, political beliefs, or reprisal or retaliation for prior civil rights activity, in any program or activity conducted or funded by USDA (not all bases apply to all programs). Remedies and complaint filing deadlines vary by program or incident.

Persons with disabilities who require alternative means of communication for program information (e.g., Braille, large print, audiotape, American Sign Language, etc.) should contact the responsible Agency or USDA's TARGET Center at (202) 720-2600 (voice and TTY) or contact USDA through the Federal Relay Service at (800) 877-8339. Additionally, program information may be made available in languages other than English.

To file a program discrimination complaint, complete the USDA Program Discrimination Complaint Form, AD-3027, found

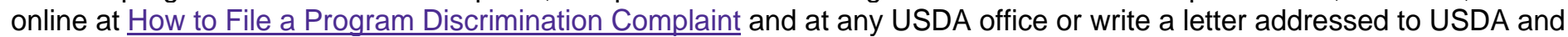
provide in the letter all of the information requested in the form. To request a copy of the complaint form, call (866) 6329992. Submit your completed form or letter to USDA by: (1) mail: U.S. Department of Agriculture, Office of the Assistant Secretary for Civil Rights, 1400 Independence Avenue, SW, Washington, D.C. 20250-9410; (2) fax: (202) 690-7442; or (3) email: program.intake@usda.gov.

USDA is an equal opportunity provider, employer, and lender.

\section{Suggested citation for this systematic review:}

Nutrition Evidence Systematic Review Team and Infant Milk-Feeding Practices Technical Expert Collaborative. Never Versus Ever Feeding Human Milk and Food Allergies, Allergic Rhinitis, Atopic Dermatitis, and Asthma: A Systematic Review. Pregnancy and Birth to 24 Months Project. Alexandria, VA: U.S. Department of Agriculture, Food and Nutrition Service, Center for Nutrition Policy and Promotion, April 2019. Available at: https://nesr.usda.gov/project-specificoverview-pb-24-0

This systematic review has also been published in the American Journal of Clinical Nutrition: Güngör D, Nadaud P, LaPergola CC, Dreibelbis C, Wong YP, Terry N, et al. Infant milk-feeding practices and food allergies, allergic rhinitis, atopic dermatitis, and asthma throughout the life span: a systematic review. Am J Clin Nutr. 2019;109(7):772S-99S. doi: 10.1093/ajcn/nqy283.

\section{Related citations are published in the American Journal of Clinical Nutrition:}

- P/B-24 Project overview:

Stoody EE, Spahn JM, Casavale KO. The Pregnancy and Birth to 24 Months Project: a series of systematic reviews on diet and health. Am J Clin Nutr. 2019;109(7):685S-97S. doi: 10.1093/ajcn/nqy372.

- P/B-24 systematic review methodology:

Obbagy JE, Spahn JM, Wong YP, Psota TL, Spill MK, Dreibelbis C, et al. Systematic review methodology used in the Pregnancy and Birth to 24 Months Project. Am J Clin Nutr. 2019;109(7):698S-704S. doi: 10.1093/ajcn/nqy226. 
Infant milk-feeding practices Technical Expert Collaborative (TEC):

- Steve A. Abrams, MD, Dell Medical School at the University of Texas at Austin

- Sue Anderson, PhD, US Food and Drug Administration (06/2015-12/2015)

- Leila Beker, PhD, RD, contractor for US Food and Drug Administration

- Kirsi M Järvinen, MD, PhD, University of Rochester Medical Center

- Laurie A. Nommsen-Rivers, PhD, RD, IBCLC, University of Cincinnati College of Allied Health Sciences (starting 09/2015)

- Kimberly O. O'Brien, PhD, Division of Nutritional Sciences, Cornell University

- Emily Oken, MD, MPH, Division of Chronic Disease Research Across the Lifecourse, Department of Population Medicine, Harvard Medical School and Harvard Pilgrim Health Care Institute, Department of Nutrition, Harvard School of Public Health

- Rafael Pérez-Escamilla, PhD, Department of Social and Behavioral Sciences, Yale School of Public Health

- Ekhard E. Ziegler, MD, Department of Pediatrics, The University of lowa

\section{Nutrition Evidence Systematic Review (NESR) team:}

- Darcy Güngör ${ }^{1}, \mathrm{MS}$, Panum Group, Lead analyst

- Perrine Nadaud, PhD, Panum Group, Analyst

- Carol Dreibelbis ${ }^{1}$, MPH, Panum Group, Analyst (starting 01/2016)

- Concetta LaPergola ${ }^{1}$, MS, Panum Group, Analyst (starting 11/2016)

- Nancy Terry, MLS, NIH, Librarian

- Yat Ping Wong, MLS, MPH, USDA, Librarian

\section{Project lead:}

- Joanne Spahn, MS, USDA

\section{Federal Expert Group (FEG)-Technical Expert Collaborative (TEC) liaisons:}

- Leila Beker, PhD, RD, US Food and Drug Administration (6/2015-4/2016)

- Tova Jacobovits, MS, RD, US Food and Drug Administration (starting 4/2016)

SAA, SA, LB, KMJ, LAN-R, KOO'B, EO, RP-E, EEZ, DG, PN, and JS participated in establishing the research questions, analytic framework, and study inclusion and exclusion criteria. YPW and NT developed the literature search strategy and conducted the literature search. PN, CD, and DG screened search results and identified studies for inclusion. DG, PN, and CL extracted data and assessed risk of bias for included studies. SAA, LB, TJ, KMJ, LAN-R, KOO'B, EO, RP-E, and EEZ reviewed and provided substantive feedback on all systematic review materials, including the synthesis of the body of evidence, conclusion statement, and grade of the strength of the evidence. DG and PN prepared this report and JMS provided oversight. All authors critically reviewed and approved the final report. The authors declare no conflicts of interest.

We thank Katherine Kortsmit and Kelly Mannherz for their assistance with extracting data and assessing risk of bias for included studies.

Funding source: United States Department of Agriculture, Food and Nutrition Service, Center for Nutrition Policy and Promotion, Alexandria, VA

\footnotetext{
${ }^{1}$ Under contract with the Food and Nutrition Service, United States Department of Agriculture.
} 


\section{TABLE OF CONTENTS}

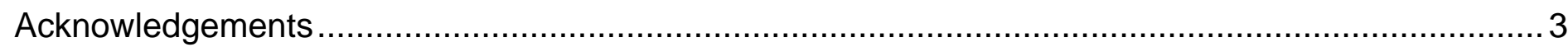

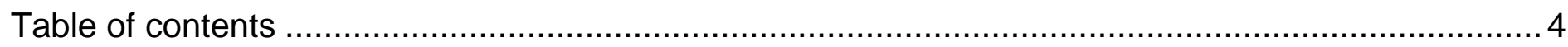

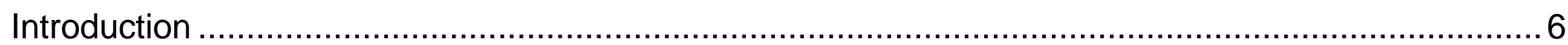

What is the relationship between never versus ever feeding human milk and food allergies, allergic

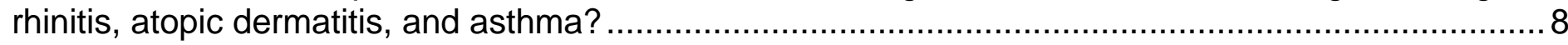

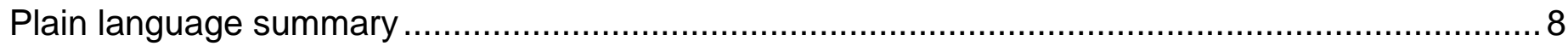

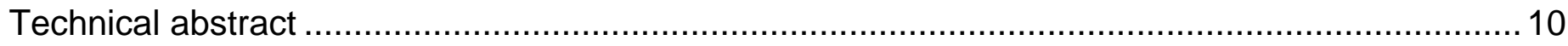

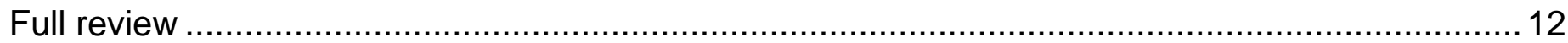

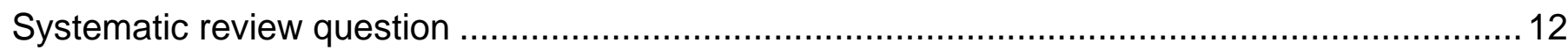

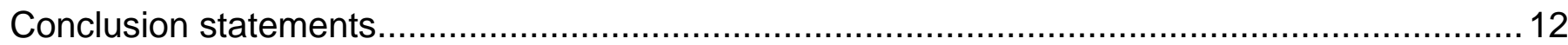

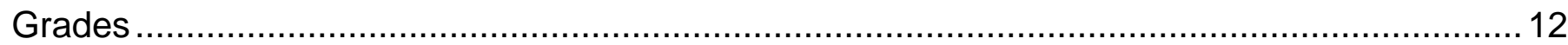

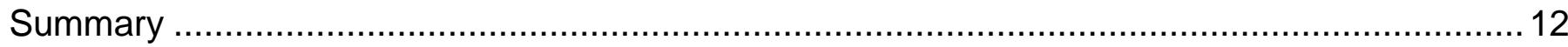

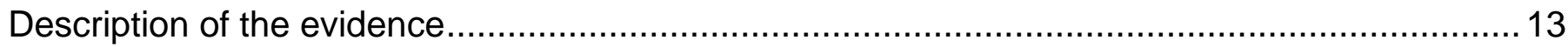

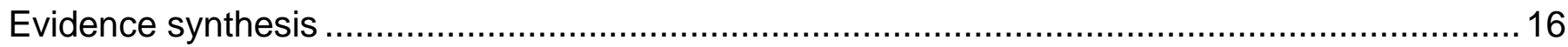

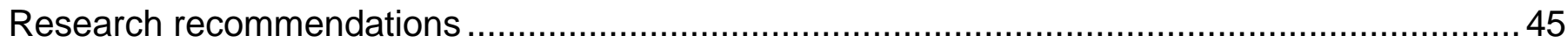

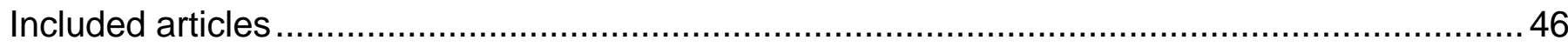

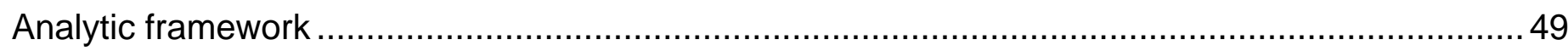

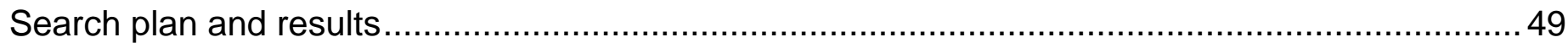

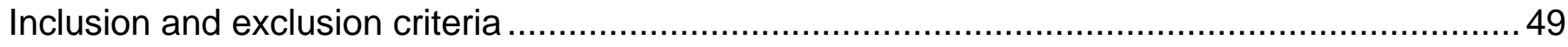

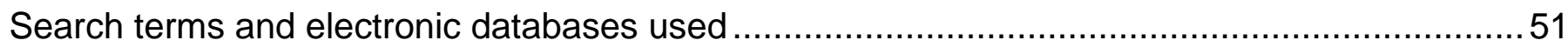

Table 1. Evidence examining the relationship between never versus ever feeding human milk and food allergies from birth to 24 months ..................................................................................... 16

Table 2. Evidence examining the relationship between never versus ever feeding human milk and food allergies in childhood ${ }^{1}$

Table 3. Evidence examining the relationship between never versus ever feeding human milk and allergic rhinitis in childhood.....

Table 4. Evidence examining the relationship between never versus ever feeding human milk and atopic dermatitis from birth to 24 months

Table 5. Evidence examining the relationship between never versus ever feeding human milk and atopic dermatitis in childhood ${ }^{1}$

Table 6. Evidence examining the relationship between never versus ever feeding human milk and asthma in childhood

Table 7. Evidence examining the relationship between never versus ever feeding human milk and asthma in childhood and adolescence together ${ }^{1}$

Table 8. Evidence examining the relationship between never versus ever feeding human milk and asthma in adolescence ${ }^{1}$

Table 9. Inclusion and exclusion criteria

Table 10. Excluded articles 


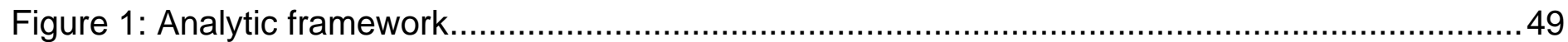

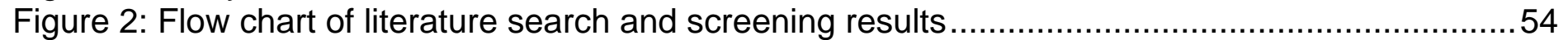


This document describes a systematic review conducted to answer the following question: What is the relationship between never versus ever feeding human milk and food allergies, allergic rhinitis, atopic dermatitis, and asthma? This systematic review was conducted as part of the Pregnancy and Birth to 24 Months (P/B-24) Project by USDA's Nutrition Evidence Systematic Review (NESR) team.

The purpose of the P/B-24 Project was to conduct a series of systematic reviews on diet and health for women who are pregnant and for infants and toddlers from birth to 24 months of age. This project was a joint initiative led by USDA and HHS, and NESR carried out all of the systematic reviews. A Federal Expert Group (FEG), a broadly representative group of Federal researchers and program leaders, also provided input throughout the P/B-24 Project. More information about the P/B-24 Project has been published ${ }^{2}$ and is available on the NESR website: https://nesr.usda.gov/project-specificoverview-pb-24-0.

NESR, formerly known as the Nutrition Evidence Library (NEL), specializes in conducting food- and nutrition-related systematic reviews using a rigorous, protocol-driven methodology. To conduct each P/B-24 systematic review, NESR's staff worked with a Technical Expert Collaborative (TEC), which is a group of 7-8 leading subject matter experts.

NESR's systematic review methodology involves developing and prioritizing systematic review questions, searching for and selecting studies, extracting and assessing the risk of bias of data from each included study, synthesizing the evidence, developing a conclusion statement, grading the evidence underlying the conclusion statement, and recommending future research. A detailed description of the methodology used in conducting systematic reviews for the P/B-24 Project has been published ${ }^{3}$ and is available on the NESR website: https://nesr.usda.gov/pb-24-projectmethodology-0. In addition, starting on page 49, this document includes details about the methodology as it was applied to the systematic review described herein. An analytic framework that illustrates the overall scope of the question, including the population, the interventions and/or exposures, comparators, and outcomes of interest, is found on page 49. In addition, the literature search plan that was used to identify studies included in this systematic review is found on page 49 .

${ }^{2}$ Stoody EE, Spahn JM, Casavale KO. The Pregnancy and Birth to 24 Months Project: a series of systematic reviews on diet and health. Am J Clin Nutr. 2019;109(7):685S-97S. doi: 10.1093/ajcn/nqy372.

${ }^{3}$ Obbagy JE, Spahn JM, Wong YP, Psota TL, Spill MK, Dreibelbis C, et al. Systematic review methodology used in the Pregnancy and Birth to 24 Months Project. Am J Clin Nutr. 2019;109(7):698S-704S. doi: 10.1093/ajcn/nqy226. 


\section{List of abbreviations}

\begin{tabular}{ll}
\hline Abbreviation & Full name \\
\hline IgE & Immunoglobulin E \\
\hline ISAAC & International Study of Asthma and Allergy in Childhood \\
\hline KOALA & Child, Parent and Health: Lifestyle and Genetic Constitution \\
\hline NESR & Nutrition Evidence Systematic Review \\
\hline TEC & Technical Expert Collaborative \\
\hline
\end{tabular}




\section{WHAT IS THE RELATIONSHIP BETWEEN NEVER VERSUS EVER FEEDING HUMAN MILK AND FOOD ALLERGIES, ALLERGIC RHINITIS, ATOPIC DERMATITIS, AND ASTHMA?}

\section{PLAIN LANGUAGE SUMMARY}

\section{What is the question?}

- The question is: What is the relationship between never versus ever feeding human milk and food allergies, allergic rhinitis, atopic dermatitis, and asthma?

What is the answer to the question?

- Moderate evidence suggests that never, in comparison to ever, being fed human milk is associated with higher risk of childhood asthma.

Limited evidence does not suggest a relationship between never versus ever being fed human milk and atopic dermatitis in childhood.

Evidence about the relationship between never versus ever being fed human milk and atopic dermatitis from birth to 24 months is inconclusive, and there is insufficient evidence to determine the relationship of never versus ever being fed human milk with food allergies throughout the lifespan, allergic rhinitis throughout the lifespan, asthma in adolescence or in adulthood, and atopic dermatitis in adolescence or in adulthood.

\section{Why was this question asked?}

- This important public health question was identified and prioritized as part of the U.S. Department of Agriculture and Department of Health and Human Services Pregnancy and Birth to 24 Months Project.

\section{How was this question answered?}

- A team of Nutrition Evidence Systematic Review staff conducted a systematic review in collaboration with a group of experts called a Technical Expert Collaborative.

What is the population of interest?

- The population of interest was generally healthy infants and toddlers (ages 0-24 months) who were in studies examining food allergies, allergic rhinitis, and atopic dermatitis throughout the lifespan and asthma from childhood through adulthood (ages 2 years and up).

\section{What evidence was found?}

- This review includes 44 articles.

- These articles compared infants who were never fed human milk with infants who were ever fed human milk (i.e., any amount of human milk).

- These articles examined available evidence related to food allergies, allergic rhinitis, atopic dermatitis, and asthma.

- Most of the evidence examined asthma and atopic dermatitis through childhood.

o Children who were never fed human milk may have higher risk of asthma than children who were ever fed human milk.

o Children who were never fed human milk and children who were ever fed human 
milk do not seem to have different risk of atopic dermatitis, but evidence from birth to 24 months was inconclusive.

- There are limitations in the evidence as follows:

o There was not a lot of evidence about food allergies or allergic rhinitis.

o There was not a lot of evidence in adolescents or adults.

o Some studies did not use strong methods to collect infant feeding data or measure outcomes.

o It is possible for factors other than infant feeding to impact the observed outcomes, and these factors were addressed differently by different studies.

o Some of the articles studied groups of children that may have been too small to detect whether there is a relationship between never versus ever feeding human milk and the outcomes.

\section{How up-to-date is this review?}

- This review includes literature from 01/1980 to 03/2016. 


\section{TECHNICAL ABSTRACT}

\section{Background}

- This systematic review was conducted as part of the U.S. Department of Agriculture and Department of Health and Human Services Pregnancy and Birth to 24 Months Project.

- The goal of this systematic review was to examine the following question: What is the relationship between never versus ever feeding human milk and food allergies, allergic rhinitis, atopic dermatitis, and asthma?

- This systematic review examines comparisons of infants who were never fed human milk with infants who were ever fed human milk (i.e., any amount of human milk feeding). Human milk feeding was defined as feeding human milk alone or in combination with infant formula and/or complementary foods or beverages such as cow's milk. Human milk was defined as mother's own milk provided at the breast (i.e., nursing) or expressed and fed fresh or after refrigeration or freezing. Donor milk (e.g., banked milk) was not examined in this review. Infant formula was defined as commercially-prepared infant formula meeting FDA and/or Codex Alimentarius international food standards.

- This systematic review examines available evidence related to food allergies, allergic rhinitis, and atopic dermatitis from birth through adulthood and asthma from childhood through adulthood (outcomes prior to childhood may represent transient recurrent wheeze ${ }^{4}$ ).

\section{Conclusion statement and grades}

- Moderate evidence suggests that never, in comparison to ever, being fed human milk is associated with higher risk of childhood asthma.

Limited evidence does not suggest a relationship between never versus ever being fed human milk and atopic dermatitis in childhood.

Evidence about the relationship between never versus ever being fed human milk and atopic dermatitis from birth to 24 months is inconclusive, and there is insufficient evidence to determine the relationship of never versus ever being fed human milk with food allergies throughout the lifespan, allergic rhinitis throughout the lifespan, asthma in adolescence or in adulthood, and atopic dermatitis in adolescence or in adulthood.

Grade: Moderate - asthma in childhood; Limited - atopic dermatitis in childhood; Grade Not Assignable - food allergies, allergic rhinitis, atopic dermatitis outside of childhood, asthma in adolescence and adulthood

\section{Methods}

- The systematic review was conducted by a team of staff from the Nutrition Evidence Systematic Review in collaboration with a Technical Expert Collaborative.

- A single literature search was conducted to identify literature for several related systematic

\footnotetext{
${ }^{4}$ Stein RT, Holberg CJ, Morgan WJ, Wright AL, Lombardi E, Taussig L, Martinez FD. Peak flow variability, methacholine responsiveness and atopy as markers for detecting different wheezing phenotypes in childhood. Thorax 1997;52(11):946-52.
} 
reviews that examined infant milk-feeding practices and different outcomes. The search was conducted in CINAHL, Cochrane, Embase, and PubMed, and used a search date range of January 1980 to March 2016. A manual search was done to identify articles that may not have been included in the electronic databases searched.

- Articles were screened independently by 2 NESR analysts to determine which articles met predetermined criteria for inclusion.

- Data from each included article were extracted, risks of bias were assessed, and both were checked for accuracy.

- The body of evidence was qualitatively synthesized, a conclusion statement was developed, and the strength of the evidence (grade) was assessed using pre-established criteria including evaluation of the internal validity/risk of bias, adequacy, consistency, impact, and generalizability of available evidence.

\section{Summary of evidence}

- Forty-four articles met the inclusion criteria for this systematic review, including 5 with evidence about food allergies, 2 with evidence about allergic rhinitis, 24 with evidence about atopic dermatitis, and 22 with evidence about asthma. Almost all of the evidence was from observational studies.

- Evidence about the association between never versus ever feeding human milk and higher childhood asthma risk was moderate. Across the 17 independent studies (19 articles) that examined asthma in children, 9 found statistically significant associations, and all of them showed that never being fed human milk was associated with higher risk. The majority of nonsignificant associations were also consistent in suggesting higher risk of childhood asthma with never versus ever feeding human milk, and some of the inconsistency in statistical significance may be explained by insufficient statistical power. The ability to draw stronger conclusions was primarily limited by the limited statistical power in some studies and concerns about internal validity such as the potential for confounding in a body of evidence primarily made up of observational studies.

- Evidence about the lack of an association between never versus ever feeding human milk and atopic dermatitis in childhood was limited. Across the 9 studies that examined atopic dermatitis in children, the only significant association was from a study that used a sample in which about half of the participants were born small for gestational age (i.e., there was a concern about generalizability). The ability to draw stronger conclusions was limited by the small number of studies, limited statistical power in some studies, concerns with generalizability of the samples to diverse U.S. populations, and concern about the potential for reverse causality and confounding.

- Evidence about atopic dermatitis from birth to 24 months was inconclusive. Across 14 independent studies (16 articles), the associations were inconsistent in direction. There was also concern about the specificity of diagnosing atopic dermatitis in this age group.

- Evidence related to food allergies and allergic rhinitis throughout the lifespan and atopic dermatitis and asthma beyond childhood was scant. 


\section{FULL REVIEW}

\section{Systematic review question}

What is the relationship between never versus ever feeding human milk and food allergies, allergic rhinitis, atopic dermatitis, and asthma?

\section{Conclusion statements}

Moderate evidence suggests that never, in comparison to ever, being fed human milk is associated with higher risk of childhood asthma.

Limited evidence does not suggest a relationship between never versus ever being fed human milk and atopic dermatitis in childhood.

Evidence about the relationship between never versus ever being fed human milk and atopic dermatitis from birth to 24 months is inconclusive, and there is insufficient evidence to determine the relationship of never versus ever being fed human milk with food allergies throughout the lifespan, allergic rhinitis throughout the lifespan, asthma in adolescence or in adulthood, and atopic dermatitis in adolescence or in adulthood.

\section{Grades}

Moderate: asthma in childhood

Limited: atopic dermatitis in childhood

Grade Not Assignable: food allergies, allergic rhinitis, atopic dermatitis outside of childhood, asthma in adolescence and adulthood

\section{Summary}

- This systematic review examines comparisons of infants who were never fed human milk with infants who were ever fed human milk (i.e., any amount of human milk feeding).

Human milk feeding was defined as feeding human milk alone or in combination with infant formula and/or complementary foods or beverages such as cow's milk. Human milk was defined as mother's own milk provided at the breast (i.e., nursing) or expressed and fed fresh or after refrigeration or freezing. Donor milk (e.g., banked milk) was not examined in this review. Infant formula was defined as commercially-prepared infant formula meeting FDA and/or Codex Alimentarius international food standards.

- This systematic review examines available evidence related to food allergies, allergic rhinitis, and atopic dermatitis from birth through adulthood and asthma from childhood through adulthood (outcomes prior to childhood may represent transient recurrent wheeze ${ }^{5}$ ).

- Forty-four articles met the inclusion criteria for this systematic review, including 5 with evidence about food allergies, 2 with evidence about allergic rhinitis, 24 with evidence about atopic dermatitis, and 22 with evidence about asthma. Almost all of the evidence was from observational studies.

- Evidence about the association between never versus ever feeding human milk and higher

\footnotetext{
${ }^{5}$ Stein RT, Holberg CJ, Morgan WJ, Wright AL, Lombardi E, Taussig L, Martinez FD. Peak flow variability, methacholine responsiveness and atopy as markers for detecting different wheezing phenotypes in childhood. Thorax 1997;52(11):946-52.
} 
childhood asthma risk was moderate. Across the 17 independent studies (19 articles) that examined asthma in children, 9 found statistically significant associations, and all of them showed that never being fed human milk was associated with higher risk. The majority of nonsignificant associations were also consistent in suggesting higher risk of childhood asthma with never versus ever feeding human milk, and some of the inconsistency in statistical significance may be explained by insufficient statistical power. The ability to draw stronger conclusions was primarily limited by the limited statistical power in some studies and concerns about internal validity such as the potential for confounding in a body of evidence primarily made up of observational studies.

- Evidence about the lack of an association between never versus ever feeding human milk and atopic dermatitis in childhood was limited. Across the 9 studies that examined atopic dermatitis in children, the only significant association was from a study that used a sample in which about half of the participants were born small for gestational age (i.e., there was a concern about generalizability). The ability to draw stronger conclusions was limited by the small number of studies, limited statistical power in some studies, concerns with generalizability of the samples to diverse U.S. populations, and concern about the potential for reverse causality and confounding.

- Evidence about atopic dermatitis from birth to 24 months was inconclusive. Across 14 independent studies (16 articles), the associations were inconsistent in direction. There was also concern about the specificity of diagnosing atopic dermatitis in this age group.

- Evidence related to food allergies and allergic rhinitis throughout the lifespan and atopic dermatitis and asthma beyond childhood was scant.

\section{Description of the evidence}

Forty-four articles met the inclusion criteria for this systematic review question (1-44). Of these, 5 presented evidence related to food allergies (1-5), 2 presented evidence related to allergic rhinitis $(6,7), 24$ presented evidence related to atopic dermatitis $(1,6,7,17,19,20,27-44)$, and 22 presented evidence related to asthma (5-26) (some articles presented evidence for more than 1 outcome).

\section{Food allergies}

Five articles presented evidence about the relationship between never versus ever feeding human milk and food allergies. One non-randomized controlled trial (1), 1 nested case-control study (2), and 1 prospective cohort study (3) presented outcomes from birth to 24 months (Table 1), 2 prospective cohort studies examined outcomes in childhood $(4,5)$ (Table 2), and no studies examined outcomes in adolescence or adulthood.

The studies were from the U.S. (4, 5), Ukraine (1), UK (2), and Denmark (3). Participants were newborn at baseline. The U.S. studies included some racial and ethnic diversity, but the remaining studies did not report race/ethnicity. Data about infant milk feeding were collected prospectively, generally from parent report, and in one case from health visitor and newborn nursery records (3). The "never" exposure included infants who did not initiate breastfeeding (2), infants categorized as never breastfed during their first month of life (3), infants who were categorized as never breastfed $(4,5)$, and infants whose mothers decided not to breastfeed and who were randomized to a group fed standard infant formula (1). The "ever" comparison included infants who initiated breastfeeding (2), infants categorized as partially breastfed/mainly cow's milk 
formula fed during their first month of life (3), and infants categorized as ever breastfed $(4,5)$ and infants breastfed for $\geq 2$ months (1). The outcomes were heterogeneous, including food allergy $(1,2,5)$, cow's milk allergy $(1,3)$ and allergy to milk, egg, or peanut $(4)$. Only one study included adjustments for confounding variables (4).

\section{Allergic rhinitis}

Two prospective cohort studies presented evidence about the relationship between never versus ever feeding human milk and allergic rhinitis in childhood $(6,7)$ (Table 3 ), and no studies examined outcomes from birth to 24 months, in adolescence, or in adulthood.

The studies were from Sweden (6) and the UK (7). The samples included high-risk participants (based on family history of allergic disease) who were newborn at baseline (7), and non-high-risk participants who were 1 to 4 years old at baseline (6). Infant-feeding data were collected by parent questionnaire (6) or by unreported methods (7). The "never" exposure for both studies was infants who were never breastfed. The "ever" comparison included infants who were ever breastfed, for any length of time (7) and infants breastfed for $>6$ months (6). In both studies the outcome was based on physician diagnosis, which was reported by parents using the validated International Study of Asthma and Allergies in Childhood (ISAAC) questionnaire in one study (6). The analyses were unadjusted.

\section{Atopic dermatitis}

Twenty-four articles presented evidence about the relationship between never versus ever being fed human milk and atopic dermatitis. Sixteen articles presented evidence from birth to 24 months $(1,20,27-40)$ (Table 4), 9 articles presented evidence in childhood $(6,7,17,19,20,41-44)$ (Table 5), and no articles presented outcomes in adolescence or adulthood.

\section{Birth to 24 months}

The 16 articles that examined never versus ever feeding human milk and atopic dermatitis from birth to 24 months presented evidence from 12 independent prospective cohort studies from the UK (27, 29, 30, 32), Netherlands (37-39), Belgium (36), Spain (33), Taiwan (28), France (31), Italy (34), and Germany (35), and there was a multinational cohort from Finland, France, Germany, and Switzerland (20). Multiple articles were included from the Child, Parent and Health: Lifestyle and Genetic Constitution (KOALA) birth cohort study from the Netherlands (37-39) because they assessed the outcome at different ages and with different outcome assessment methods. The non-randomized controlled trial was from Ukraine (1). The case-control study was from Italy (40).

All of the studies except for the case-control study recruited participants who were newborn at baseline. The case-control study recruited participants who were between 3 and 24 months, with a median of 5 months, at the time of the study (40). Race/ethnicity was unreported for all but the German sample (35) which was $90 \%$ German, $2.4 \%$ Turkish, and $7.6 \%$ other. Three studies recruited at-risk samples (based on family history of allergic disease) $(27,31,32)$.

Data about infant milk-feeding practices was collected by parent report. The "never" exposure included infants who were never breastfed (20, 27-29, 32-40), breastfed zero months (34), categorized as formula fed (31) or bottle fed when "bottle fed" was defined as an infant milkfeeding practice distinct from breastfeeding (30), and randomized to a group fed standard infant formula (1).The "ever" exposure included infants who were breastfed $(27,29,31,32,34,36,38$, 
40), categorized as breastfed for heterogeneous ranges of duration $(1,20,28,30,33-39)$, breastfed only (34), and breastfed only for specific durations (34).

Outcomes included atopic dermatitis from birth to 13 weeks (30), birth to 3 months (38), birth to 6 months (33), birth to 12 months $(27,32,34,36,38)$, birth to 14 months (33), birth to 18 months (1), birth to 2 years $(20,29,35,37,39), 14$ to 26 weeks (30), 4 to 12 months (38), 7 to 14 months (33), 27 to 39 weeks (30), 40 to 52 weeks (30), and 6 to 18 months (28) at 3 to 24 months (40), 7 to 14 months (33), and at 2 years $(31,37,39)$. One study measured atopic dermatitis that recurred in the birth to 6 month period and the 7 to 14 month period (33), and another measured severity at 2 years (31). The outcome measure was based on medical exam (1, 27, 29-32, 35, 37, $39,40)$, parent report of medical diagnosis or morbidity $(20,28,33,36-39)$, and mothers' opinion (29).

\section{Childhood}

Eight prospective cohort studies $(6,7,17,19,20,41,42,44)$ and 1 nested case-control study (43) examined the relationship between never versus ever being fed human milk and atopic dermatitis in childhood. The studies were from the UK $(7,19,44)$, Belgium (43), Germany (41), Sweden (6), Australia (17), and New Zealand (42), and there was a multinational study from Finland, France, Germany, and Switzerland (20).

Only one study did not follow participants from birth; in the study by Larsson et al. (6) participants were 1 to 4 years of age at baseline. Only 1 study reported race or ethnicity; all participants in the study from New Zealand were of European descent (42). A few studies recruited high-risk or "risk-enriched" samples based on family history of allergic disease or IgE levels $(7,17,41)$, and one study had a large proportion of participants (approximately half) who were born small for gestational age (42).

Data about infant milk-feeding practices were collected by parent report via diary, questionnaire, and interview. Infants never fed human milk were compared to infants categorized as ever fed human milk $(7,17,19,36,41,44)$ or fed human milk for heterogeneous ranges of duration $(6,19$, 20, 42).

Atopic dermatitis was defined based on parent responses to items from the ISAAC questionnaire $(6,19,43)$, parent report of a physician's diagnosis $(17,20,44)$, a positive Scoring Atopic Dermatitis score (20), or physical examination plus parent-reported case history $(7,17,41,42)$. Bergman et al. (41), Burr et al. (7) Mihrshahi et al. (17) examined atopic dermatitis in at risk or "risk enriched" samples based on family history or IgE levels. The comparisons of interest by Sariachvili et al. (43), Larsson et al. (6) and Burr et al. (7) were unadjusted, whereas the remaining studies considered a range of confounders.

\section{Asthma}

Twenty-two identified articles examined never versus ever feeding human milk and asthma. Almost all of them presented evidence on asthma in children (5-7, 9-24) or children and adolescents together $(25,26)$. One article examined outcomes in adolescents only (8). No articles examined outcomes in adults.

Nineteen articles examined asthma in children only (5-7, 9-24). These articles presented evidence from 14 prospective cohort studies $(6,7,9,10,13,14,16,17,19-24), 1$ additional cohort with prospective and retrospective analyses in separate articles $(5,18), 1$ nested casecontrol study (15), and 1 case-control study with unique evidence across 2 articles $(11,12)$ (i.e., 
there were 17 independent studies in total). These studies were from the U.S. $(5,10,18,26)$, Canada (11, 12, 15, 16), UK (7, 9, 19, 24), Netherlands (14, 21, 23), Australia (17), Sweden (6), Hong Kong (13), and Spain (22), and there was a multinational study from Finland, France, Germany, and Switzerland (20). A prospective cohort study (25) and a case-control study (26), both from the U.S., examined asthma in children and adolescents together. A single prospective cohort study from Australia examined asthma in adolescents only (8).

With 2 exceptions $(6,16)$, participants in the prospective cohort studies were enrolled as newborns, and in the case-control studies participants were 3 to $4(11,12)$ and 6 to 14 years of age (26). Most studies did not report race or ethnicity; the U.S.-based samples, however, included some racial and ethnic diversity $(5,10,18,25,26)$. The studies by Burr et al. (7) and Martel et al. (15) specifically recruited individuals with family history of allergic disease to assemble high-risk samples.

Data about infant milk-feeding practices were collected from parent report by questionnaire, interview, or diary, and studies compared infants who never consumed human milk with infants ever fed human milk $(5,7,9-13,17-19,22,24,25)$, fed human milk for heterogeneous ranges of duration $(6,8,14-16,19-21,23,26)$, and fed human milk exclusively $\geq 3$ months (13) or until weaning (24). Asthma outcomes were based on medical record $(11-13,15,18)$, clinical assessment $(7,14,17)$, parent report of a diagnosis or symptoms $(5-7,10,16-18,20-25)$, and parent report via the validated instrument from the International Study of Asthma and Allergy in Childhood $(6,19)$. Although the analyses of interest in some of the studies were unadjusted $(5,7$, $9,18,23)$, the majority included important adjustment variables that varied between studies.

\section{Evidence synthesis}

\section{Food allergies}

The available evidence was insufficient to determine the relationship between never versus ever feeding human milk and food allergies throughout the lifespan. There were only three studies of outcomes from birth to 24 months (1-3) (Table 1), two studies of outcomes in childhood $(4,5)$ (Table 2), and no studies of outcomes in adolescence or adulthood. This small number of studies examined heterogeneous outcomes, including food allergy, cow's milk allergy, and allergy to milk, egg, or peanut. The studies also had limited methodological rigor; for example, only one study controlled for confounding variables (4).

\section{Table 1. Evidence examining the relationship between never versus ever feeding human milk and food allergies from birth to 24 months $^{1}$}

Article

Study design

(study name when

applicable)

Country
Notable sample characteristics
Never versus ever feeding human milk exposure $^{2}$
Significant associations with food allergies
Nonsignificant associations with food allergies

\begin{tabular}{|c|c|c|c|c|}
\hline Grimshaw 2013 (2) & $\mathrm{N}=41$ cases, 82 controls & BF initiated vs not & None & Proportion of cases with \\
\hline Nested case control & Baseline: Birth & & & food allergy by 2 y vs \\
\hline UK & Race/ethnicity NR & & & $\begin{array}{l}\text { BF: } 92.7 \% \text { vs } 96.3 \% \text {, } \\
p=0.210\end{array}$ \\
\hline
\end{tabular}


Article

Study design (study name when applicable)

Notable sample characteristics

\section{Country}

\begin{tabular}{|c|c|c|c|c|}
\hline $\begin{array}{l}\text { Host } 1991(3) \\
\text { Prospective cohort } \\
\text { Denmark }\end{array}$ & $\begin{array}{l}\mathrm{N}=1,749 \\
\text { Baseline: Birth } \\
\text { Sex NR } \\
\text { Race/ethnicity NR }\end{array}$ & $\begin{array}{l}\text { Never BF vs Partially } \\
\text { BF/mainly cow's milk FF } \\
\text { during the 1st mo }\end{array}$ & $\begin{array}{l}\text { Proportion of cohort } \\
\text { who never BF vs } \\
\text { partially BF/mainly } \\
\text { cow's milk FF during the } \\
1 \text { st mo with cow's milk } \\
\text { allergy at } 1 \text { y: } 1.4 \% \text { vs } \\
0 \%, p<0.01\end{array}$ & None \\
\hline $\begin{array}{l}\text { Ivakhnenko } 2013 \text { (1) } \\
\text { Non-randomized } \\
\text { controlled trial }^{3} \text { (PIFA) } \\
\text { Ukraine }\end{array}$ & $\begin{array}{l}\mathrm{N}=104 \text { for the } \\
\text { comparison of interest } \\
\text { Baseline: Birth } \\
\text { Sex NR } \\
\text { Race/ethnicity NR }\end{array}$ & BF vs Standard FF & $\begin{array}{l}\text { Proportion infants who } \\
\text { were BF vs Standard } \\
\text { FF with allergic } \\
\text { reactions to food by } 18 \\
\text { mo: } 3.92 \% \text { vs } 16.98 \% \text {, } \\
\text { p<0.05 } \\
\text { Proportion of infants } \\
\text { who were BF vs } \\
\text { Standard FF with } \\
\text { allergic reactions to } \\
\text { cow's milk protein by } 18 \\
\text { mo: } 1.96 \% \text { vs } 15.09 \% \text {, } \\
\text { p<0.01 }\end{array}$ & None \\
\hline
\end{tabular}

Never versus ever feeding human milk exposure $^{2}$
Significant associations with food allergies
Nonsignificant associations with food allergies 
Table 2. Evidence examining the relationship between never versus ever feeding human milk and food allergies in childhood ${ }^{1}$

Article

Study design

(cohort name when applicable)

Country

\begin{tabular}{|c|c|c|c|c|}
\hline McGowan 2015 (4) & $N=501$ & Ever BF vs Never BF & \multirow{3}{*}{$\begin{array}{l}\text { Proportion of } \\
\text { participants with vs } \\
\text { without food allergy by } 5 \\
\text { y who ever BF: } 68.8 \% \\
\text { vs } 52.9 \%, p=0.05\end{array}$} & \multirow[t]{3}{*}{ None } \\
\hline \multirow{2}{*}{$\begin{array}{l}\text { Prospective cohort } \\
\text { (URECA) } \\
\text { US }\end{array}$} & Baseline: Birth & & & \\
\hline & $\begin{array}{l}\text { Race/ethnicity: } \\
20.5 \% \text { Hispanic } \\
69.5 \% \text { Black alone } \\
1.1 \% \text { White alone } \\
6.6 \%>1 \text { race } \\
1.1 \% \text { other } \\
1.1 \% \text { NR }\end{array}$ & & & \\
\hline Milner 2004 (5) & $N=8,073$ & \multirow[t]{3}{*}{ Ever BF vs Never BF } & \multirow{3}{*}{$\begin{array}{l}\text { Food allergies by } 3 \mathrm{y} \text { : } \\
\text { OR } 1.39 \text { ( } 95 \% \mathrm{Cl}: 1.13 \text {, } \\
1.71)\end{array}$} & \multirow[t]{3}{*}{ None } \\
\hline Prospective cohort & Baseline: Birth & & & \\
\hline US & $\begin{array}{l}\text { Race/ethnicity: } \\
\text { 51\% Black } \\
\text { 46\% White } \\
\text { 3\% Other }\end{array}$ & & & \\
\hline
\end{tabular}

1 Abbreviations: BF - breastfed/breastfeeding, Cl - confidence interval, FF - formula fed/formula feeding, mo - months, NMIHS/LF - 1988 National Maternal and Infant Health Survey and 1991 Longitudinal Follow-up, NR - not reported, OR - odds ratio, PIFA - Prevalence Of Infant Food Allergy, URECA - Urban Environment And Childhood Asthma, y- years

2 Exposures, as defined by the authors of the studies included in the body of evidence, which address never versus ever feeding human milk or vice versa

3 Study was an RCT however the data of interest for this SR used a non-randomized comparison group 


\section{Allergic rhinitis}

The available evidence was insufficient to determine the relationship between never versus ever feeding human milk and allergic rhinitis throughout the lifespan. There were only two studies of outcomes in childhood $(6,7)$ (Table 3), and no studies of outcomes from birth to 24 months, in adolescence, or in adulthood. This small number of studies used limited methodological rigor. For example, neither study controlled for confounding variables.

Table 3. Evidence examining the relationship between never versus ever feeding human milk and allergic rhinitis in childhood ${ }^{1}$

Article

Study design (study/cohort name when applicable)

Country

\begin{tabular}{|c|c|c|c|c|}
\hline $\begin{array}{l}\text { Burr } 1993(7) \\
\text { Prospective cohort }^{3} \\
\text { UK }\end{array}$ & $\begin{array}{l}\mathrm{N}=453 \\
\text { Baseline: Birth } \\
\text { Race/ethnicity NR } \\
\text { Risk: } 100 \% \text { family } \\
\text { history (parent or sibling) }\end{array}$ & Ever BF vs Never BF & None & $\begin{array}{l}\text { Proportion of infants who } \\
\text { ever BF vs never BF } \\
\text { with allergic rhinitis at } \\
\text { age } 7 y: 26 \% \text { vs } 27 \% \text {, NS }\end{array}$ \\
\hline $\begin{array}{l}\text { Larsson } 2008 \text { (6) } \\
\text { Prospective cohort } \\
\text { (DBH) } \\
\text { Sweden }\end{array}$ & $\begin{array}{l}\mathrm{N}=4,779 \\
\text { Baseline: 1-4 y } \\
\text { Race/ethnicity NR }\end{array}$ & No $B F$ vs $B F>6$ mo & None & $\begin{array}{l}\text { Incidence of rhinitis } \\
\text { during the 5-y } \\
\text { observation period (from } \\
\text { participant age 1-4 y to } \\
6-9 \text { y): OR } 1.11 \text { ( } 95 \% \mathrm{Cl} \text { : } \\
0.53,2.30 \text { ) } \\
\text { Incidence of any rhinitis } \\
\text { symptoms during the } 5-\mathrm{y} \\
\text { observation period (from } \\
\text { participant age } 1-4 \mathrm{y} \text { to } \\
6-9 \text { y): OR } 1.12 \text { ( } 95 \% \mathrm{Cl} \text { : } \\
0.69,1.83 \text { ) }\end{array}$ \\
\hline
\end{tabular}

\begin{tabular}{|c|c|c|}
\hline $\begin{array}{l}\text { Never versus ever } \\
\text { feeding human milk } \\
\text { exposure }^{2}\end{array}$ & $\begin{array}{l}\text { Significant } \\
\text { associations with } \\
\text { allergic rhinitis }\end{array}$ & $\begin{array}{l}\text { Nonsignificant } \\
\text { associations with } \\
\text { allergic rhinitis }\end{array}$ \\
\hline
\end{tabular}

Notable sample characteristics allergic rhinitis associations with allergic rhinitis $0.69,1.83)$

1 Abbreviations: BF - breastfed/breastfeeding, Cl - confidence interval, DBH - Dampness in Buildings and Health, mo - months, NR - not reported, NS nonsignificant, OR - odds ratio, y- years

2 Exposures, as defined by the authors of the studies included in the body of evidence, which address never versus ever feeding human milk or vice versa

3 The cohort was sampled from an RCT however the data of interest for this SR are unrelated to randomization 


\section{Atopic dermatitis}

The available evidence was insufficient to draw conclusions about the relationship between never versus ever feeding human milk and atopic dermatitis in age groups other than childhood. The evidence from birth to 24 months was inconclusive, as described below, and no articles presented outcomes in adolescence or adulthood.

\section{Birth to 24 months}

The evidence for never versus ever feeding human milk and atopic dermatitis from birth to 24 months (Table 4) was inconclusive. Across the 16 articles, the small number of significant associations was inconsistent in direction. Ivakhnenko et al. (1) found that a larger proportion of infants fed infant formula than fed human milk had atopic dermatitis by 18 months of age $(16.98 \%$ versus $3.92 \%, p<0.05)$, whereas Chuang et al. (28) found that being fed human milk for durations of $\leq 1, \leq 2, \leq 6, \leq 12$, and $>12$ months (in comparison to not being fed human milk) were associated with higher odds of atopic dermatitis between 6 and 18 months of age (ORs between 1.25 and 1.49). In a third study, Snijders et al. (37) found that being fed human milk $>9$ months (in comparison to never being fed human milk) was associated with lower odds of eczema by 2 years of age in a subsample of children whose mothers had no allergies or asthma (OR: 0.51; 95\% Cl: 0.29, 0.89). However, the significant association was limited to 1 (37) of the 3 articles by Snijders et al. (37-39) about the KOALA birth cohort study, and to 1 of the 12 relevant analyses in the article. The nonsignificant associations were also inconsistent in direction, with no discernable trend in the direction of the point estimates $(20,27,29-36,40)$. In addition to the mixed evidence, there were concerns about the specificity of the diagnosis of atopic dermatitis from birth to 24 months.

\section{Childhood}

The available evidence does not suggest a relationship between never versus ever feeding human milk and atopic dermatitis in childhood (Table 5). Most of the associations between never versus ever feeding human milk and atopic dermatitis in childhood were nonsignificant. The only study with statistically significant associations was by Purvis et al. (42). However, the associations from this study may not be generalizable because the study was originally intended to examine differences between babies born small and appropriate for gestational age, and recruited a sample in which about half of the participants were born small for gestational age (although the study authors noted that this was accounted for in the statistical analysis). In the remaining studies, the nonsignificant associations were inconsistent in direction.

There are limitations to the adequacy, generalizability, and internal validity of the evidence. With regard to adequacy, there were only 9 studies and the samples in 3 of the studies $(17,20,41)$ may have been too small to have sufficient statistical power to examine the comparisons of interest for this systematic review, as they had wide confidence intervals around their nonsignificant associations. As noted above, there were limitations to the generalizability of the evidence presented by Purvis et al. (42). In addition, although all of the studies were conducted in countries listed as high or very high on the 2014 Human Development Index ${ }^{6}$, according to the inclusion criteria, there were no studies from the U.S. and no studies reported having racially or ethnically diverse samples. A few studies included high-risk samples (based on family history or IgE levels) $(7,17,41)$; this may present a source of reverse causation because atopic disease in parents or older siblings may influence parents' feeding decisions as they try to prevent atopic

\footnotetext{
${ }^{6}$ United Nations Development Programme. Human Development Report 2014. Sustaining Human Progress: Reducing Vulnerabilities and Building Resilience. New York, 2014
} 
disease in their infants. Confounding can arise because differences between feeding groups were not mitigated by randomization (due to ethical issues around allocating infants to be fed no human milk) and infant-feeding decisions can be strongly socially patterned; 3 of the studies did not control for confounding variables $(6,7,43)$.

\section{Table 4. Evidence examining the relationship between never versus ever feeding human milk} and atopic dermatitis from birth to 24 months $^{1}$

Article

Study design (study/cohort name when applicable)

Country

\begin{tabular}{ll}
\hline $\begin{array}{l}\text { Burr } 1989 \text { (27) } \\
\text { Prospective cohort }\end{array}$ & $\mathrm{N}=483$ \\
UK & Baseline: Birth \\
& Race/ethnicity NR \\
& $\begin{array}{l}\text { Risk: } 100 \% \text { family } \\
\text { history (parent or sib }\end{array}$ \\
& $\mathrm{N}=20,172$ \\
$\begin{array}{l}\text { Chuang 2011 (28) } \\
\text { (TBCS) }\end{array}$ & Baseline: Birth \\
Taiwan & Race/ethnicity NR \\
& $\begin{array}{l}\text { Risk: 0\% with atopic } \\
\text { dermatitis by } 6 \text { mo } \\
\text { (exclusion criterion) }\end{array}$
\end{tabular}

\begin{tabular}{|c|c|c|}
\hline $\begin{array}{l}\text { Never versus ever } \\
\text { feeding human milk } \\
\text { exposure }^{2}\end{array}$ & $\begin{array}{l}\text { Significant } \\
\text { associations with } \\
\text { atopic dermatitis }\end{array}$ & $\begin{array}{l}\text { Nonsignificant } \\
\text { associations with } \\
\text { atopic dermatitis }\end{array}$ \\
\hline
\end{tabular}

BF at some time vs None Never BF

Proportion of infants BF at some time vs Never BF with eczema symptoms by $12 \mathrm{mo}$ : $35 \%$ vs $40 \%$, NS

BF $\leq 1$ mo vs No BF Atopic dermatitis None
between 6-18 mo: OR 1.25 (95\% Cl: 1.00, 1.56), $p=0.049$

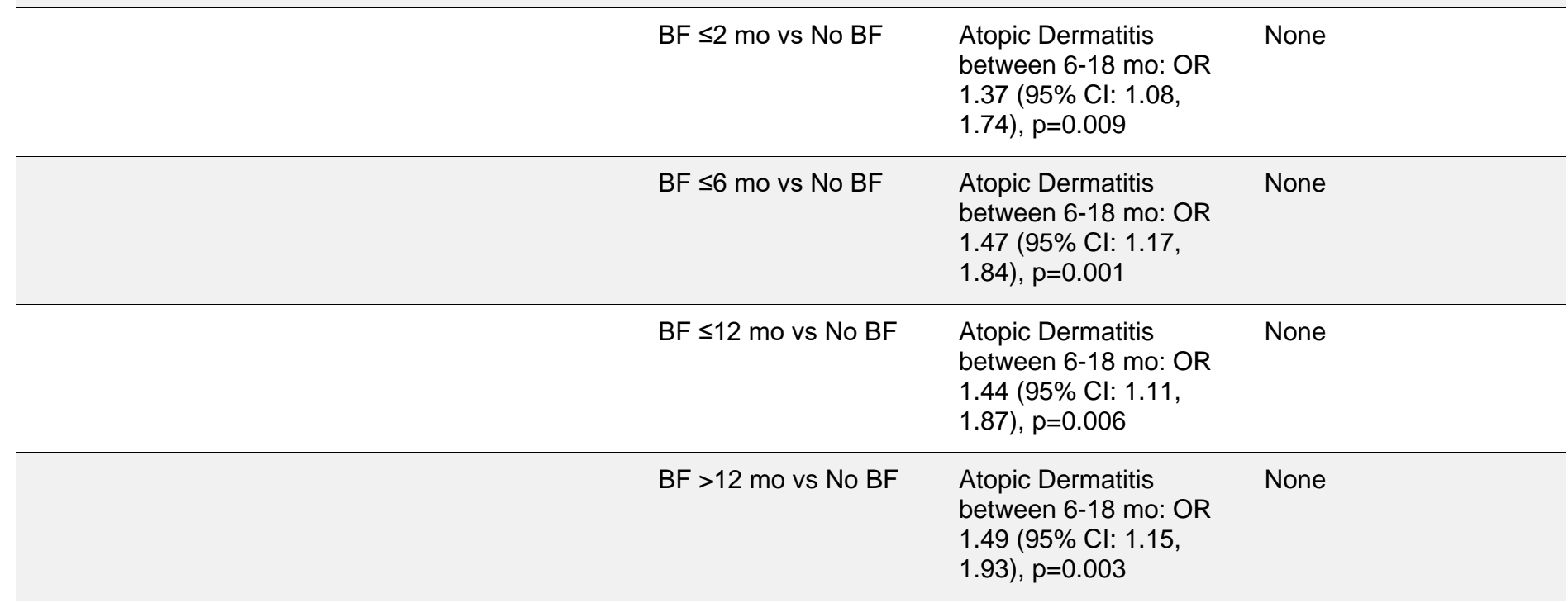


Article

\section{Study design} (study/cohort name when applicable)

\section{Country}

\begin{tabular}{|c|c|c|c|c|}
\hline \multirow[t]{3}{*}{$\begin{array}{l}\text { Harris } 2001(29) \\
\text { Prospective cohort } \\
\text { UK }\end{array}$} & $\begin{array}{l}\mathrm{N}=624 \\
\text { Baseline: Birth } \\
\text { Race/ethnicity NR }\end{array}$ & \multirow[t]{3}{*}{ Ever BF vs Never BF } & \multirow[t]{3}{*}{ None } & $\begin{array}{l}\text { Doctor-diagnosed } \\
\text { eczema by } 2 \text { y: OR } 0.97 \\
(95 \% \mathrm{Cl}: 0.64,1.47), \\
p=0.89\end{array}$ \\
\hline & & & & $\begin{array}{l}\text { Visible dermatitis by } 2 \text { y: } \\
\text { OR } 1.25(95 \% \mathrm{Cl}: 0.67 \text {, } \\
2.35), p=0.47\end{array}$ \\
\hline & & & & $\begin{array}{l}\text { Maternally reported } \\
\text { eczema by } 2 \text { y: OR } 0.93 \\
(95 \% \mathrm{Cl}: 0.63,1.36), \\
p=0.71\end{array}$ \\
\hline \multirow{10}{*}{$\begin{array}{l}\text { Howie } 1990(30) \\
\text { Prospective cohort } \\
\text { UK }\end{array}$} & $\mathrm{N}=617$ & \multirow{6}{*}{$\begin{array}{l}\text { Bottle feeders (FF) vs } \\
\text { early weaners (BF }<13 \\
\text { wk) }\end{array}$} & \multirow[t]{6}{*}{ None } & \multirow{2}{*}{$\begin{array}{l}\text { Eczema from birth to } 13 \\
\text { wk: X2 } 2.36(95 \% \mathrm{Cl} \text { : } \\
\text { NR), NS }\end{array}$} \\
\hline & \multirow{5}{*}{$\begin{array}{l}\text { Baseline: Birth } \\
\text { Sex NR } \\
\text { Race/ethnicity NR }\end{array}$} & & & \\
\hline & & & & \multirow{2}{*}{$\begin{array}{l}\text { Eczema from } 14-26 \text { wk: } \\
\text { X2 } 1.52(95 \% \mathrm{Cl} \text { : NR), } \\
\text { NS }\end{array}$} \\
\hline & & & & \\
\hline & & & & $\begin{array}{l}\text { Eczema from 27-39 wk: } \\
\text { x2 } 0.02(95 \% \mathrm{Cl}: \mathrm{NR}) \\
\text { NS }\end{array}$ \\
\hline & & & & $\begin{array}{l}\text { Eczema from } 40-52 \text { wk: } \\
\text { X2 } 0.15(95 \% \mathrm{Cl}: \mathrm{NR}) \\
\text { NS }\end{array}$ \\
\hline & & \multirow[t]{4}{*}{$\begin{array}{l}\text { Bottle feeders (FF) vs } \\
\text { breast feeders (BF } \geq 13 \\
\text { wk) }\end{array}$} & \multirow[t]{4}{*}{ None } & $\begin{array}{l}\text { Eczema from birth to } 13 \\
\text { wk: x2 } 0.77(95 \% \mathrm{Cl}:- \\
3.2,2.4)\end{array}$ \\
\hline & & & & $\begin{array}{l}\text { Eczema from 14-26 wk: } \\
\text { x2 } 0.89 \text { (95\% Cl: }-1.3 \\
6.6)\end{array}$ \\
\hline & & & & $\begin{array}{l}\text { Eczema from } 27-39 \text { wk: } \\
\text { x2 } 0.58 \text { (95\% Cl: }-3.6 \\
3.6)\end{array}$ \\
\hline & & & & $\begin{array}{l}\text { Eczema from } 40-52 \text { wk: } \\
\text { x2 } 0.12(95 \% \mathrm{Cl}:-3.5 \\
4.6)\end{array}$ \\
\hline Ivakhnenko 2013 (1) & $N=104$ & \multirow[t]{4}{*}{ BF vs Standard FF } & \multirow{4}{*}{$\begin{array}{l}\text { Proportion of infants BF } \\
\text { vs Standard FF with } \\
\text { atopic dermatitis during } \\
\text { the first } 18 \text { mo: } 3.92 \% \\
\text { vs } 16.98 \%, p<0.05\end{array}$} & \multirow[t]{4}{*}{ None } \\
\hline \multirow{2}{*}{$\begin{array}{l}\text { Non-randomized } \\
\text { controlled trial }{ }^{4}\end{array}$} & Baseline: Birth & & & \\
\hline & Sex NR & & & \\
\hline Ukraine & Race/ethnicity NR & & & \\
\hline
\end{tabular}

Never versus ever feeding human milk exposure $^{2}$
Significant associations with atopic dermatitis
Nonsignificant associations with atopic dermatitis
Notable sample characteristics 
Article

Study design (study/cohort name when applicable)

\section{Country}

\begin{tabular}{|c|c|c|c|c|}
\hline Mallet 1992 (31) & $\mathrm{N}=139$ & \multirow[t]{5}{*}{ FF alone vs FF with BF } & \multirow[t]{5}{*}{ None } & \multirow[t]{5}{*}{$\begin{array}{l}\text { Eczema at } 2 \text { y: NS (data } \\
\text { NR) }\end{array}$} \\
\hline Prospective cohort ${ }^{3}$ & Baseline: Birth & & & \\
\hline \multirow[t]{3}{*}{ France } & Sex NR & & & \\
\hline & Race/ethnicity NR & & & \\
\hline & $\begin{array}{l}\text { Risk: } 100 \% \text { family } \\
\text { history ( } \geq 1 \text { parent or } \\
\text { sibling) }\end{array}$ & & & \\
\hline Miskelly 1988 (32) & $N=487$ & \multirow[t]{4}{*}{ Ever BF vs Never BF } & \multirow[t]{4}{*}{ None } & \multirow{4}{*}{$\begin{array}{l}\text { Eczema in the first year } \\
\text { of life: } 35 \% \text { vs } 40 \% \text {, NS }\end{array}$} \\
\hline Prospective cohort ${ }^{3}$ & Baseline: Birth & & & \\
\hline \multirow[t]{2}{*}{ UK } & Race/ethnicity NR & & & \\
\hline & $\begin{array}{l}\text { Risk: } 100 \% \text { family } \\
\text { history ( } \geq 1 \text { parent or } \\
\text { sibling) }\end{array}$ & & & \\
\hline Morales 2012 (33) & $N=580$ & \multirow{6}{*}{$\begin{array}{l}\text { Predominant BF }<2 \text { mo } \\
\text { vs Never BF }\end{array}$} & \multirow[t]{6}{*}{ None } & \multirow{2}{*}{$\begin{array}{l}\text { Atopic eczema from } \\
\text { birth-6 mo: OR } \sim 0.7 \\
(95 \% \mathrm{Cl}: \sim 0.3, \sim 1.5)\end{array}$} \\
\hline $\begin{array}{l}\text { Prospective cohort } \\
\text { (INMA Project) }\end{array}$ & Baseline: Birth & & & \\
\hline \multirow[t]{4}{*}{ Spain } & \multirow{4}{*}{ Race/ethnicity NR } & & & $\begin{array}{l}\text { Atopic eczema from 7- } \\
14 \text { mo: OR } \sim 0.6(95 \% \\
\mathrm{Cl}: \sim 0.3, \sim 1.3)\end{array}$ \\
\hline & & & & $\begin{array}{l}\text { Recurrent atopic } \\
\text { eczema from birth- } 6 \text { mo } \\
\text { to } 7-14 \text { mo: OR } \sim 0.4 \\
(95 \% \mathrm{Cl}: \sim 0.0, \sim 1.3)\end{array}$ \\
\hline & & & & $\begin{array}{l}\text { Atopic eczema from 0- } \\
14 \text { mo: OR } 0.67(95 \% \\
\text { Cl: } 0.33,1.36)\end{array}$ \\
\hline & & & & $\begin{array}{l}\text { Atopic eczema from } 7 \text { - } \\
14 \text { mo in subsample of } \\
\text { infants with onset } \geq 7 \\
\text { mo: OR } 0.75(95 \% \mathrm{Cl} \text { : } \\
0.27,2.08)\end{array}$ \\
\hline
\end{tabular}

Never versus ever feeding human milk exposure $^{2}$

Significant associations with atopic dermatitis
Nonsignificant associations with atopic dermatitis
Notable sample

characteristics 
Article
Notable sample characteristics
Never versus ever feeding human milk exposure $^{2}$
Significant associations with atopic dermatitis
Nonsignificant associations with atopic dermatitis

\section{Country}

Predominant BF 2-4

mo vs Never BF
None 
Article

\section{Study design (study/cohort name when applicable)}

\section{Country} Notable sample
characteristics
Never versus ever feeding human milk exposure $^{2}$
Significant associations with atopic dermatitis
Nonsignificant associations with atopic dermatitis
Predominant BF $>6$ mo None vs Never BF
Atopic eczema from 714 mo: OR $\sim 0.6(95 \%$

$\mathrm{Cl}: 0.2, \sim 1.4$ )

Recurrent atopic eczema from birth- 6 mo to 7-14 mo: OR $\sim 0.7$ (95\% Cl: $\sim 0.2, \sim 2.0)$

Atopic eczema from 0 14 mo: OR 0.64 (95\% Cl: $0.28,1.44)$

Atopic eczema from 7 14 mo in subsample of infants with onset $\geq 7$ mo: OR 0.42 (95\% Cl: $0.11,1.57)$

\section{Orivuori 2014 (20) (PASTURE)}

$N=853$

Never $\mathrm{BF}$ vs $\mathrm{BF}>6 \mathrm{mo}$

None

Baseline: Birth

Race/ethnicity NR
Atopic dermatitis up to 2 y: OR $0.84(95 \% \mathrm{Cl}$ : $0.40,1.76$ )

Finland, France,

Germany, Switzerland

\begin{tabular}{|c|c|c|c|c|}
\hline $\begin{array}{l}\text { Parazzini } 2014 \text { (34) } \\
\text { Prospective cohort } \\
\text { Italy }\end{array}$ & $\begin{array}{l}\mathrm{N}=796 \\
\text { Baseline: Birth } \\
\text { Race/ethnicity NR }\end{array}$ & BF only vs No BF & None & $\begin{array}{l}\text { 12-month incidence of } \\
\text { atopic dermatitis at } 12 \\
\text { mo: RR } 1.34(95 \% \mathrm{Cl} \text { : } \\
0.90,2.02)\end{array}$ \\
\hline & & $\begin{array}{l}\text { BF/other milks vs No } \\
\text { BF }\end{array}$ & None & $\begin{array}{l}\text { 12-month incidence of } \\
\text { atopic dermatitis at } 12 \\
\text { mo: RR } 1.13(95 \% \mathrm{Cl} \text { : } \\
0.71,1.80)\end{array}$ \\
\hline & & $\begin{array}{l}\text { BF only 1-4 mo vs BF } \\
0 \text { mo }\end{array}$ & None & $\begin{array}{l}\text { 12-month incidence of } \\
\text { atopic dermatitis at } 12 \\
\text { mo: RR } 1.28(95 \% \mathrm{Cl} \text { : } \\
0.70,2.35)\end{array}$ \\
\hline & & $\begin{array}{l}\text { BF only } \geq 5 \text { mo vs BF } 0 \\
\text { mo }\end{array}$ & None & $\begin{array}{l}\text { 12-month incidence of } \\
\text { atopic dermatitis at } 12 \\
\text { mo: RR } 1.46(95 \% \mathrm{Cl} \text { : } \\
0.95,2.25)\end{array}$ \\
\hline & & $\begin{array}{l}\text { BF/other milks 1-4 mo } \\
\text { vs BF } 0 \text { mo }\end{array}$ & None & $\begin{array}{l}\text { 12-month incidence of } \\
\text { atopic dermatitis at } 12 \\
\text { mo: RR } 1.15(95 \% \mathrm{Cl} \text { : } \\
0.72,1.84)\end{array}$ \\
\hline & & $\begin{array}{l}\text { BF/other milks } \geq 5 \mathrm{mo} \\
\text { vs BF } 0 \mathrm{mo}\end{array}$ & None & $\begin{array}{l}\text { 12-month incidence of } \\
\text { atopic dermatitis at } 12 \\
\text { mo: RR } 1.39(95 \% \mathrm{Cl} \text { : } \\
0.91,2.12)\end{array}$ \\
\hline
\end{tabular}


Article

\section{Study design (study/cohort name when applicable)}

\section{Country}

\begin{tabular}{|c|c|c|c|c|}
\hline \multirow[t]{4}{*}{$\begin{array}{l}\text { Rothenbacher } 2005 \\
\text { (35) } \\
\text { Prospective cohort } \\
\text { Germany }\end{array}$} & $\begin{array}{l}\mathrm{N}=803 \\
\text { Baseline: Birth } \\
\text { Race/ethnicity: NR, } \\
\text { nationality: } 90.0 \% \\
\text { German, } 2.4 \% \text { Turkish, } \\
\text { 7.6\% other }\end{array}$ & BF $<3$ mo vs Never BF & None & $\begin{array}{l}\text { Cumulative incidence of } \\
\text { atopic dermatitis at } 2 \text { y: } \\
27.5 \% \text { vs } 13.2 \% \text {, NS }\end{array}$ \\
\hline & & $\begin{array}{l}\text { BF } 3 \text { to }<6 \text { mo vs } \\
\text { Never BF }\end{array}$ & None & $\begin{array}{l}\text { Cumulative incidence of } \\
\text { atopic dermatitis at } 2 \text { y: } \\
22.1 \% \text { vs } 13.2 \% \text {, NS }\end{array}$ \\
\hline & & $\begin{array}{l}\text { BF } 6 \text { to }<9 \text { mo vs } \\
\text { Never BF }\end{array}$ & None & $\begin{array}{l}\text { Cumulative incidence of } \\
\text { atopic dermatitis at } 2 \text { y: } \\
17.9 \% \text { vs } 13.2 \% \text {, NS }\end{array}$ \\
\hline & & $\mathrm{BF} \geq 9 \mathrm{mo}$ vs Never BF & None & $\begin{array}{l}\text { Cumulative incidence of } \\
\text { atopic dermatitis at } 2 \mathrm{y} \text { : } \\
21.3 \% \text { vs } 13.2 \% \text {, NS }\end{array}$ \\
\hline $\begin{array}{l}\text { Sariachvili } 2007 \text { (36) } \\
\text { Prospective cohort } \\
\text { (PIPO Project) } \\
\text { Reloium }\end{array}$ & $\begin{array}{l}\mathrm{N}=976 \\
\text { Baseline: Birth } \\
\text { Race/ethnicity NR }\end{array}$ & Ever BF vs Never BF & None & $\begin{array}{l}\text { Eczema during the } 1 \text { st } \\
\text { year: OR } 1.3(95 \% \mathrm{Cl} \text { : } \\
0.9,1.8)\end{array}$ \\
\hline \multirow{3}{*}{ Belgium } & & $\begin{array}{l}\text { BF 1-6 mo vs Never } \\
\text { BF }\end{array}$ & None & $\begin{array}{l}\text { Eczema during the } 1 \text { st } \\
\text { year: OR } 0.8(95 \% \mathrm{Cl} \text { : } \\
0.4,1.3)\end{array}$ \\
\hline & & $\begin{array}{l}\text { BF 7-12 mo vs Never } \\
\text { BF }\end{array}$ & None & $\begin{array}{l}\text { Eczema during the } 1 \text { st } \\
\text { year: OR } 0.8(95 \% \mathrm{Cl} \text { : } \\
0.5,1.3)\end{array}$ \\
\hline & & $\begin{array}{l}\mathrm{BF} \geq 13 \text { mo vs Never } \\
\mathrm{BF}\end{array}$ & None & $\begin{array}{l}\text { Eczema during the 1st } \\
\text { year: OR } 1.0(95 \% \mathrm{Cl} \text { : } \\
0.6,1.5)\end{array}$ \\
\hline $\begin{array}{l}\text { Snijders } 2007 \text { (37) } \\
\text { Prospective cohort } \\
\text { (KOALA Birth Cohort) }\end{array}$ & \multirow{2}{*}{$\begin{array}{l}\mathrm{N}=2,516,1,538 \text { in the } \\
\text { subsample with mothers } \\
\text { with no allergy/no } \\
\text { asthma, } 652 \text { in the } \\
\text { subsample with mothers } \\
\text { with allergy/no asthma, } \\
217 \text { in the subsample } \\
\text { with mothers with } \\
\text { asthma }\end{array}$} & \multirow[t]{3}{*}{$\begin{array}{l}\text { BF 0-3 mo vs Never } \\
\text { BF }\end{array}$} & \multirow[t]{3}{*}{ None } & $\begin{array}{l}\text { Eczema in the first } 2 \text { y in } \\
\text { subsample with mothers } \\
\text { with no allergy, no } \\
\text { asthma: OR } 0.90(95 \% \\
\text { Cl: } 0.61,1.31)\end{array}$ \\
\hline Netherlands & & & & $\begin{array}{l}\text { Eczema in the first } 2 \text { y in } \\
\text { subsample with mothers } \\
\text { with allergy, no asthma: } \\
\text { OR } 0.90 \text { (95\% Cl: } 0.52 \text {, } \\
1.57)\end{array}$ \\
\hline & Race/ethnicity NR & & & $\begin{array}{l}\text { Eczema in the first } 2 \text { y in } \\
\text { subsample with mothers } \\
\text { with asthma: OR } 1.39 \\
(95 \% \mathrm{Cl}: 0.51,3.78)\end{array}$ \\
\hline
\end{tabular}

Never versus ever feeding human milk exposure $^{2}$
Significant associations with atopic dermatitis
Nonsignificant associations with atopic dermatitis
Notable sample
characteristics 


\section{Study design (study/cohort name when applicable)}

\section{Country}

\section{Notable sample characteristics}

Never versus ever feeding human milk exposure $^{2}$
Significant associations with atopic dermatitis
Nonsignificant associations with atopic dermatitis
BF 4-6 mo vs Never None BF
Eczema in the first $2 \mathrm{y}$ in subsample with mothers with no allergy, no asthma: OR 0.71 (95\% $\mathrm{Cl}: 0.42,1.20)$

Eczema in the first $2 \mathrm{y}$ in subsample with mothers with allergy, no asthma: OR 0.86 (95\% Cl: 0.43 , 1.71)

Eczema in the first $2 \mathrm{y}$ in subsample with mothers with asthma: OR 1.40 (95\% Cl: 0.44, 4.42)

BF 7-9 mo vs Never None BF

Eczema in the first $2 \mathrm{y}$ in subsample with mothers with no allergy, no asthma: OR 0.69 (95\% Cl: $0.40,1.19)$

Eczema in the first $2 \mathrm{y}$ in subsample with mothers with allergy, no asthma: OR 0.68 (95\% Cl: 0.34, 1.38)

Eczema in the first $2 \mathrm{y}$ in subsample with mothers with asthma: OR 0.70 (95\% Cl: $0.22,2.27)$

BF $>9$ mo vs Never BF Eczema in the first $2 y$ in subsample with mothers with no allergy, no asthma: OR 0.51 (95\% Cl: 0.29, 0.89)
Eczema in the first $2 \mathrm{y}$ in subsample with mothers with allergy, no asthma: OR 0.63 (95\% Cl: 0.31, 1.29)

Eczema in the first $2 \mathrm{y}$ in subsample with mothers with asthma: OR 1.67 (95\% Cl: 0.53, 5.21)

\begin{tabular}{|c|c|c|c|c|}
\hline \multirow[t]{2}{*}{$\begin{array}{l}\text { Snijders } 2007 \text { (38) } \\
\text { Prospective cohort } \\
\text { (KOALA Birth Cohort) }\end{array}$} & \multirow{2}{*}{\multicolumn{3}{|c|}{$\begin{array}{l}\text { Baseline: Birth } \\
\text { Race/ethnicity NR }\end{array}$}} & \multirow[t]{2}{*}{$\begin{array}{l}\text { Early development of } \\
\text { eczema (0-3 mo): OR } \\
1.30(95 \% \mathrm{Cl}: 0.96, \\
1.77)\end{array}$} \\
\hline & & & & \\
\hline & & \multirow[t]{2}{*}{$\begin{array}{l}\text { BF 0-3 mo vs Never } \\
\text { BF }\end{array}$} & \multirow[t]{2}{*}{ None } & $\begin{array}{l}\text { Eczema during 1st y of } \\
\text { life: OR } 0.98(95 \% \mathrm{Cl} \text { : } \\
0.71,1.34)\end{array}$ \\
\hline & & & & $\begin{array}{l}\text { Eczema between } 4 \text { and } \\
12 \text { mo: OR } 0.98(95 \% \\
\mathrm{Cl}: 0.66,1.46)\end{array}$ \\
\hline
\end{tabular}


Article

\section{Study design (study/cohort name when applicable)}

Country
Notable sample characteristics
Never versus ever feeding human milk exposure $^{2}$
Significant associations with atopic dermatitis
Nonsignificant associations with atopic dermatitis

\begin{tabular}{|c|c|c|c|c|}
\hline & & $\begin{array}{l}\text { BF 4-6 mo vs Never } \\
\text { BF }\end{array}$ & None & $\begin{array}{l}\text { Eczema during 1st y of } \\
\text { life: OR } 0.94(95 \% \mathrm{Cl} \text { : } \\
0.66,1.34)\end{array}$ \\
\hline & & BF $\geq 7$ mo vs Never BF & None & $\begin{array}{l}\text { Eczema during } 1 \text { st y of } \\
\text { life: OR } 0.80(95 \% \mathrm{Cl} \text { : } \\
0.57,1.12)\end{array}$ \\
\hline & & BF $\geq 4$ mo vs Never BF & None & $\begin{array}{l}\text { Eczema between } 4 \text { and } \\
12 \text { mo: OR } 0.77(95 \% \\
\mathrm{Cl}: 0.52,1.15)\end{array}$ \\
\hline \multirow{9}{*}{$\begin{array}{l}\text { Snijders } 2008 \text { (39) } \\
\text { Prospective cohort } \\
\text { (KOALA Birth Cohort) } \\
\text { Netherlands }\end{array}$} & $\mathrm{N}=2,434$ & \multirow{3}{*}{$\begin{array}{l}\text { BF 0-3 mo vs Never } \\
\text { BF }\end{array}$} & \multirow[t]{3}{*}{ None } & \multirow{2}{*}{$\begin{array}{l}\text { Eczema (parent report) } \\
\text { by } 2 \text { y: OR } 1.00(95 \% \mathrm{Cl} \\
: 0.75,1.33)\end{array}$} \\
\hline & \multirow{2}{*}{$\begin{array}{l}\text { Baseline: Birth } \\
\text { Race/ethnicity NR }\end{array}$} & & & \\
\hline & & & & $\begin{array}{l}\text { Atopic dermatitis } \\
\text { (assessed) at } 2 \text { y: OR } \\
1.11(95 \% \mathrm{Cl}: 0.51 \text {, } \\
2.41)\end{array}$ \\
\hline & & \multirow[t]{2}{*}{$\begin{array}{l}\text { BF 4-6 mo vs Never } \\
\text { BF }\end{array}$} & \multirow[t]{2}{*}{ None } & $\begin{array}{l}\text { Eczema (parent report) } \\
\text { by } 2 \text { y: OR } 0.87(95 \% \\
\mathrm{Cl}: 0.55,1.35)\end{array}$ \\
\hline & & & & $\begin{array}{l}\text { Atopic dermatitis } \\
\text { (assessed) at } 2 \text { y: OR } \\
2.58(95 \% \mathrm{Cl}: 0.77, \\
8.67)\end{array}$ \\
\hline & & \multirow[t]{2}{*}{$\begin{array}{l}\text { BF 7-9 mo vs Never } \\
\text { BF }\end{array}$} & \multirow[t]{2}{*}{ None } & $\begin{array}{l}\text { Eczema (parent report) } \\
\text { by } 2 \text { y: OR } 0.74(95 \% \\
\text { Cl: } 0.46,1.20)\end{array}$ \\
\hline & & & & $\begin{array}{l}\text { Atopic dermatitis } \\
\text { (assessed) at } 2 \text { y: OR } \\
1.58(95 \% \mathrm{Cl}: 0.44, \\
5.66)\end{array}$ \\
\hline & & \multirow[t]{2}{*}{ BF $>9$ mo vs Never BF } & \multirow[t]{2}{*}{ None } & $\begin{array}{l}\text { Eczema (parent report) } \\
\text { by } 2 \text { y: OR } 0.66(95 \% \\
\mathrm{Cl}: 0.40,1.09)\end{array}$ \\
\hline & & & & $\begin{array}{l}\text { Atopic dermatitis } \\
\text { (assessed) at } 2 \text { y: OR } \\
1.30 \text { (95\% Cl: } 0.34, \\
4.95)\end{array}$ \\
\hline \multirow{5}{*}{$\begin{array}{l}\text { Turati } 2016(40) \\
\text { Case control } \\
\text { Italy }\end{array}$} & $\mathrm{N}=451$ cases, 451 & \multirow[t]{5}{*}{ Never BF vs Ever BF } & \multirow[t]{5}{*}{ None } & \multirow{5}{*}{$\begin{array}{l}\text { Atopic dermatitis at } \\
\text { study inclusion (age } 3 \text { to } \\
24 \text { mo): OR } 0.68(95 \% \\
\mathrm{Cl}: 0.38,1.24)\end{array}$} \\
\hline & controls & & & \\
\hline & $\begin{array}{l}\text { Baseline: Median } 5 \text { mo } \\
\text { (Range 3-24) }\end{array}$ & & & \\
\hline & Sex: $67 \%$ male & & & \\
\hline & Race/ethnicity NR & & & \\
\hline
\end{tabular}


Table 5. Evidence examining the relationship between never versus ever feeding human milk and atopic dermatitis in childhood ${ }^{1}$

\section{Article}

\section{Study design} (study/cohort name when applicable)

\section{Country}

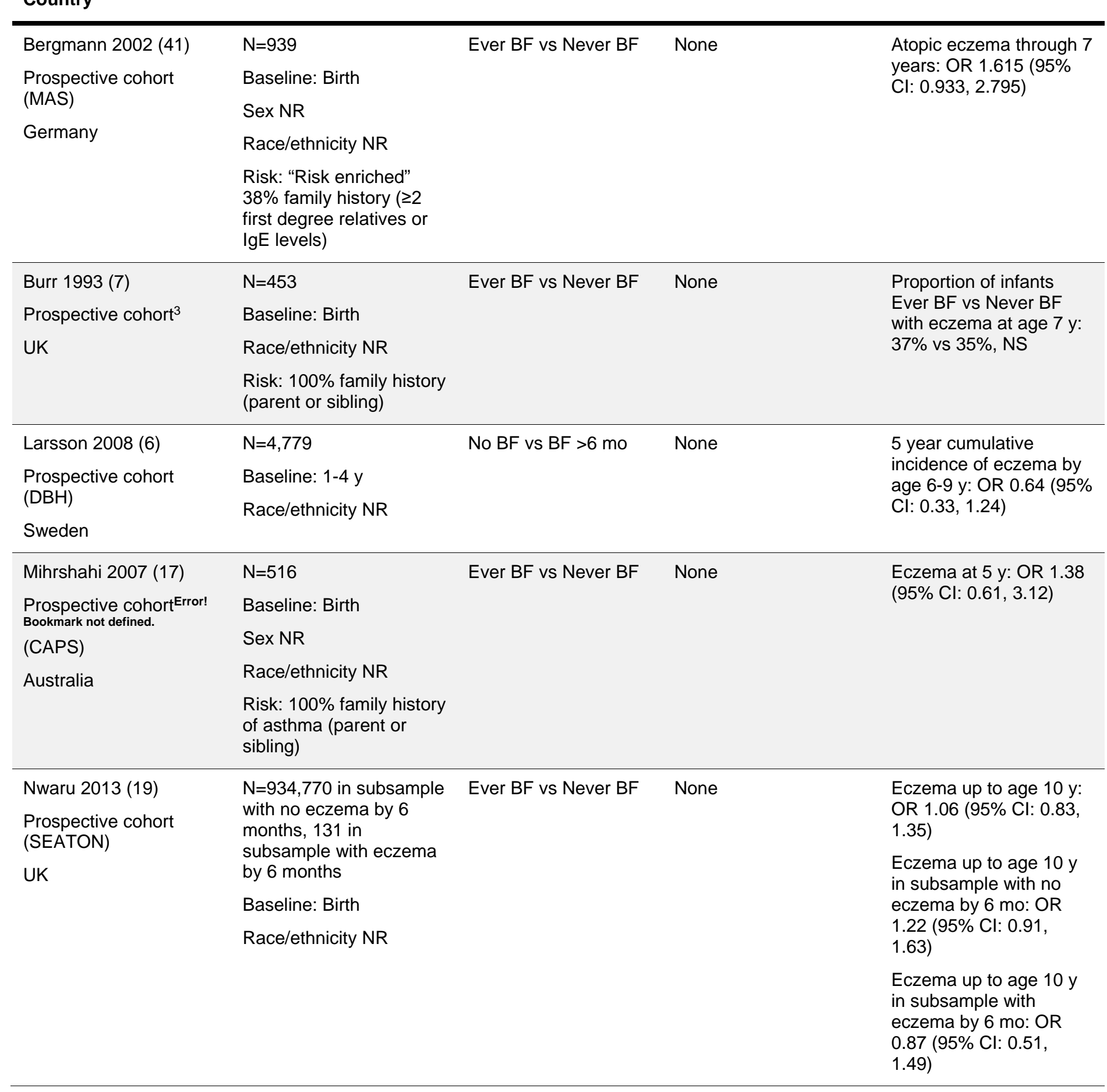

\section{Never versus ever feeding human milk \\ exposure $^{2}$ \\ Significant associations with atopic dermatitis \\ Nonsignificant associations with atopic dermatitis}

Notable sample
characteristics 
Article

\section{Study design (study/cohort name when applicable)}

\section{Country}

\section{Notable sample characteristics}

Never versus ever feeding human milk exposure $^{2}$
Significant associations with atopic dermatitis
Nonsignificant associations with atopic dermatitis

\begin{tabular}{|c|c|c|c|c|}
\hline & & $\begin{array}{l}\text { BF }<2.25 \text { mo vs Never } \\
\text { BF }\end{array}$ & None & $\begin{array}{l}\text { Eczema up to age } 10 \text { y: } \\
\text { OR } 1.12 \text { ( } 95 \% \mathrm{Cl}: 0.84 \text {, } \\
1.51) \\
\text { Eczema up to age } 10 \text { y } \\
\text { in subsample with no } \\
\text { eczema by } 6 \text { mo: OR } \\
1.25 \text { (95\% Cl: } 0.87 \text {, } \\
1.79) \\
\text { Eczema up to age } 10 \text { y } \\
\text { in subsample with } \\
\text { eczema by } 6 \text { mo: OR } \\
0.95 \text { (95\% Cl: } 0.50 \text {, } \\
1.81)\end{array}$ \\
\hline & & $\begin{array}{l}\mathrm{BF} \geq 2.25 \text { mo vs Never } \\
\mathrm{BF}\end{array}$ & None & $\begin{array}{l}\text { Eczema up to age } 10 \text { y: } \\
\text { OR } 1.04 \text { ( } 95 \% \mathrm{Cl}: 0.81 \text {, } \\
1.35) \\
\text { Eczema up to age } 10 \text { y } \\
\text { in subsample with no } \\
\text { eczema by } 6 \text { mo: OR } \\
1.23 \text { ( } 95 \% \mathrm{Cl}: 0.90 \text {, } \\
1.68) \\
\text { Eczema up to age } 10 \text { y } \\
\text { in subsample with } \\
\text { eczema by } 6 \text { mo: OR } \\
0.83 \text { ( } 95 \% \mathrm{Cl}: 0.46 \text {, } \\
1.50)\end{array}$ \\
\hline $\begin{array}{l}\text { Orivuori } 2014 \text { (20) } \\
\text { Prospective cohort } \\
\text { (PASTURE) } \\
\text { Finland, France, } \\
\text { Germany, Switzerland }\end{array}$ & $\begin{array}{l}\mathrm{N}=853 \\
\text { Baseline: Birth } \\
\text { Race/ethnicity NR }\end{array}$ & $\begin{array}{l}\text { Never BF vs BF >6 } \\
\text { mo }\end{array}$ & None & $\begin{array}{l}\text { Atopic dermatitis up to } 4 \\
\text { y: OR } 0.83(95 \% \mathrm{Cl} \text { : } \\
0.40,1.69)\end{array}$ \\
\hline $\begin{array}{l}\text { Purvis } 2005 \text { (42) } \\
\text { Prospective cohort }{ }^{5} \\
\text { (ABC Study) } \\
\text { New Zealand }\end{array}$ & $\begin{array}{l}\mathrm{N}=550 \\
\text { Baseline: Birth } \\
\text { Race/ethnicity: NR; } \\
\text { 100\% New Zealanders } \\
\text { of European descent } \\
\text { Risk: } 50 \% \text { born SGA }\end{array}$ & $\begin{array}{l}\mathrm{BF}<6 \text { mo vs Never } \\
\mathrm{BF}\end{array}$ & $\begin{array}{l}\text { Atopic dermatitis at } 3.5 \\
\text { y: OR } 6.12(95 \% \mathrm{Cl} \text { : } \\
1.22,30.7)\end{array}$ & None \\
\hline & & $\mathrm{BF} \geq 6 \mathrm{mo}$ vs Never BF & $\begin{array}{l}\text { Atopic dermatitis at } 3.5 \\
\text { y: OR } 12.0(95 \% \mathrm{Cl} \text { : } \\
2.62,54.8)\end{array}$ & None \\
\hline $\begin{array}{l}\text { Sariachvili } 2010 \text { (43) } \\
\text { Nested case control } \\
\text { (PIPO Project) }\end{array}$ & $\begin{array}{l}\mathrm{N}=252 \text { cases, } 305 \\
\text { controls } \\
\text { Baseline: Birth }\end{array}$ & Ever BF vs Never BF & None & $\begin{array}{l}\text { Eczema up to age } 4 \text { y: } \\
\text { OR } 0.77 \text { (95\% Cl: } 0.50 \text {, } \\
1.18)\end{array}$ \\
\hline Belgium & Race/ethnicity NR & & & \\
\hline
\end{tabular}


Article

\begin{tabular}{lllll}
$\begin{array}{l}\text { Study design } \\
\text { (study/cohort name } \\
\text { when applicable) }\end{array}$ & $\begin{array}{l}\text { Notable sample } \\
\text { characteristics }\end{array}$ & $\begin{array}{l}\text { Never versus ever } \\
\text { feeding human milk } \\
\text { exposure }\end{array}$ & $\begin{array}{l}\text { Significant } \\
\text { associations with } \\
\text { atopic dermatitis }\end{array}$ & $\begin{array}{l}\text { Nonsignificant } \\
\text { associations with } \\
\text { atopic dermatitis }\end{array}$ \\
\hline $\begin{array}{l}\text { Zutavern } 2004(44) \\
\text { Prospective cohort }\end{array}$ & $\mathrm{N}=604$ & Ever BF vs Never BF & None & Eczema by age 5.5y: OR \\
UK & Baseline: Birth & & & 0.71 (95\% Cl: 0.47, 1.1) \\
\hline
\end{tabular}

\footnotetext{
${ }^{1}$ Abbreviations: ABC Study - Auckland Birthweight Collaborative, BF - breastfed/breastfeeding, CAPS - Childhood Asthma Prevention Study, CI confidence interval, DBH-Dampness in Buildings and Health, FF - formula fed/formula feeding, INMA Project - INfancia y Medio Ambiente, KOALA Birth Cohort - Child, Parent and Health: Lifestyle and Genetic Constitution, MAS - Multicentre Allergy Study, mo - months, NR - not reported, NS not significant, OR - odds ratio, PASTURE - Protection Against Allergy Study in Rural Environments, PIPO Project - Prospective study on the Influence of Perinatal factors on the Occurrence of asthma and allergies, RR - relative risk, SGA - small for gestational age, SEATON - Study of Eczema and Asthma To Observe the influence of Nutrition, TBCS - Taiwan Birth Cohort Study, UK - United Kingdom, wk - weeks, y - years

${ }^{2}$ Exposures, as defined by the authors of the studies included in the body of evidence, which address never versus ever feeding human milk or vice versa

${ }^{3}$ The cohort was sampled from an RCT however the data of interest for this SR are unrelated to randomization

${ }^{4}$ Study was an RCT however the data of interest for this SR used a non-randomized comparison group

${ }^{5}$ The cohort was sampled from a case-control study however the data of interest for this SR are unrelated to case/control status
} 


\section{Asthma}

The available evidence was insufficient to draw conclusions about the relationship between never versus ever feeding human milk and asthma in age groups other than childhood. There was scant evidence on outcomes in adolescents alone (8) and mixed evidence from studies that examined adolescents and children together $(25,26)$. There were no studies of outcomes in adulthood.

Across the 21 articles that presented evidence about never versus ever being fed human milk and asthma in childhood (5-7, 9-26), the evidence differed between the studies that included children only $(5-7,9-24)$ and the studies that included children as well as adolescents $(25,26)$.

\section{Evidence in children only}

Statistically significant associations were reported by 9 studies across 11 articles $(5,6,11,12$, $14-16,18,21,22,24)$. The studies provided consistent evidence of an association between never versus ever being fed human milk and higher asthma risk, and suggested that the predominant difference between the statistically significant and nonsignificant associations was statistical power.

Seven of the studies that found significant associations were prospective cohort studies.

Specifically, Larsson et al. (6) compared children never fed human milk with children fed human milk $>6$ months and found higher odds of asthma during the 5-year observation period in the full sample of children with no asthma at baseline [1 to 4 years of age (OR: $2.64 ; 95 \% \mathrm{Cl}: 1.28$, 5.46)], and in subsamples of children who did and did not have wheezing at baseline (OR: 4.08; 95\% Cl: 1.21, 13.72 and OR: 2.64; 95\% Cl: 1.18, 5.93, respectively).

Maas et al. (14) found lower odds of allergic asthma at 6 years of age when being fed human milk 12 to 25 weeks was compared to not being fed human milk (OR: $0.247 ; 95 \% \mathrm{Cl}$ : 0.093, 0.655), and when the exposure was being fed human milk 1 to 11 weeks the upper limit of the confidence interval was 1.003. A comparison of being fed human milk $\geq 26$ weeks with not being fed human milk had a nonsignificant association in the same direction with a wide confidence interval indicative of suboptimal statistical power.

Midodzi et al. (16) reported a lower hazard ratio for asthma at 2 to 5 years of age when children fed human milk >3 months were compared to those never fed human milk (HR: 0.82; $95 \% \mathrm{Cl}$ : $0.69,0.97)$. Further, when the exposure was being fed human milk 0 to 3 months, the upper limit of the confidence interval around the nonsignificant association was 1.00.

Miller et al. (18) and Milner et al. (5) examined the same cohort. In prospective analyses, ever being fed human milk was associated with lower odds of asthma by maternal report at (5) and by (18) 3 years of age (OR: 0.61; 95\% Cl: 0.52, 0.71 and OR: 0.68; 95\% Cl: 0.49, 0.97, respectively). When Miller et al. (18) used physician reports from a retrospective medical chart review to determine whether children had been diagnosed with asthma by 3 years of age, the association was in the same direction but was not statistically significant (OR: 0.94; $95 \% \mathrm{Cl}$ : 0.70 , 1.26). The authors described several plausible reasons for the discrepancy between maternal report and medical records, including response rate (i.e., the presence of maternal report when medical providers did not respond), health care utilization (i.e., the presence of maternal report when a medical record did not exist due to socioeconomic factors), and medical coding (e.g., for ease, providers may have coded reactive airway disease as asthma in medical charts); however, an additional explanation is that the analyses in both articles were unadjusted and may have been prone to confounding.

Scholtens et al. (21) examined asthma in the full sample and subsamples of children with allergic and non-allergic mothers. The full sample analyses found lower odds of asthma in 3-, 5-, 6-, 7-, 
and 8-year-olds (ORs between 0.50 and 0.65 ) and lower odds of chronic asthma by 8 years of age (OR: $0.65 ; 95 \% \mathrm{Cl}: 0.44,0.96$ ) in children fed human milk $>16$ weeks than in those not fed human milk, and the association at 4 years of age was in the same direction but not statistically significant. The subsample analyses of children with non-allergic mothers were very similar, although chronic asthma by 8 years of age was not assessed. In the subsample analyses of children with allergic mothers, the associations were in the same direction but not statistically significant, with the exception of a lower odds of asthma at 3 years of age.

Sunyer et al. (22) found that children fed human milk had lower odds of asthma at 6.5 years of age than children never fed human milk (OR: 0.33; 95\% Cl: 0.08, 0.87).

Wilson et al. (24) reported that the percentage probability of asthma by 7 years of age was higher in children never fed human milk (18.6\%; 95\% Cl: 17.2, 20.0) than in children who were exclusively fed human milk (12.1\%; $95 \% \mathrm{Cl}$ : 10.9, 13.4). However, a comparison of never versus partial feeding of human milk was not statistically significant.

In a nested case-control study, Martel et al. (15) examined a sample in which about $85 \%$ of both cases and controls had mothers with a history of asthma and found lower odds of childhood asthma up to 10 years of age when being fed human milk $<6$ months was compared to never being fed human milk (OR: $0.70 ; 95 \% \mathrm{Cl}: 0.53,0.92$ ). When being fed human milk $\geq 6$ months was compared to never being fed human milk, the upper limit of the confidence interval was 1.03.

Finally, in a case-control study, Infante-Rivard et al. (11) compared never to ever being fed human milk and reported higher odds of asthma at 3 to 4 years of age (OR: $1.47 ; 95 \% \mathrm{Cl}: 1.02$, 2.13). When the study examined asthma that persisted from 3 to 4 years of age to 9 to 11 years of age, and transient asthma that was present at 3 to 4 years of age but not at 9 to 11 years of age (12), the associations were in the same direction but had wider confidence intervals indicative of suboptimal statistical power (OR: 1.30; 95\% Cl: 0.85, 2.01 and OR: 1.17; 95\% Cl: $0.60,2.28$, respectively).

The majority of nonsignificant associations were consistent in direction with the significant associations $(10,12,14-19,21,23)$, suggesting that never being fed human milk was associated with a higher risk of childhood asthma, and some of the nonsignificance was explainable due to inadequate power. The minority of nonsignificant associations were discrepant $(7,13,20)$ or did not report point estimates so direction could not be assessed (9). Some of the nonsignificant associations were from unadjusted analyses $(7,9,23)$ and may have been prone to confounding.

The evidence related to never versus ever being fed human milk and asthma in childhood was graded moderate after considering the adequacy, consistency, impact, generalizability, and internal validity of the evidence. Seventeen independent studies examined never versus ever being fed human milk and asthma in children and the statistically significant associations all showed that never being fed human milk was associated with higher risk of asthma $(5,6,11,14$ $16,18,21,22,24)$. The majority of nonsignificant associations were also consistent in suggesting higher risk with never versus ever feeding human milk, and some of the inconsistency in statistical significance may be explained by insufficient statistical power resulting in wide confidence intervals. Evidence was consistent despite heterogeneous independent variables resulting from not defining ever for the systematic review, and instead including all relevant comparisons.

In the NESR grading rubric, the impact of the evidence takes into consideration the directness with which the study designs examined the link between the exposure and outcome of interest in the systematic review question, and the clinical significance of the evidence. Although some 
studies' original objectives were not explicitly stated, most studies described objectives related to examining the link between feeding human milk and asthma; 4 studies were indirect $(6,7,14$, 17). Regarding clinical significance, asthma affects the quality of life for millions of children in the U.S. and can be life-threatening; therefore, even small decreases in the risk for asthma have the potential to be of public health importance.

The generalizability of the evidence to U.S. populations had a few limitations, but was sound overall. There were 5 North American studies with evidence about never versus ever feeding human milk and childhood asthma, and the 2 U.S. studies used racially and ethnically diverse samples. The samples were from countries that were high or very high on the 2014 Human Development Index ${ }^{7}$ and therefore had a level of human development likely generalizable to the U.S.

There were some concerns about internal validity. Infant milk-feeding research can be prone to detection bias because infant milk-feeding data are often collected using parent reporting methods that may not be valid and reliable; however, most studies collected these data prospectively, which reduces recall bias. Confounding can arise because differences between feeding groups are rarely mitigated by randomization (due to ethical issues around allocating infants to be fed no human milk) and infant-feeding decisions can be strongly socially patterned. However, most studies adjusted for confounding variables deemed important and feasible to control, although the specific adjustment variables varied between studies. Reverse causation can be a major concern because asthma in parents or older siblings may influence parents' feeding decisions as they try to prevent asthma in their infants. However, the majority of studies found no baseline differences in family history of atopic disease between groups or included family history of atopic disease as an adjustment variable (6, 10-13, 15-17, 20-22, 24). Attrition bias, due to high attrition, differential attrition, or both, may have existed among some of the studies in the body of evidence $(6,8,10,15,18,19,21,24,25)$; however, these studies were not more concentrated among the studies with significant versus nonsignificant associations.

\section{Evidence from studies including both children and adolescents together}

The prospective cohort study (25) and case-control study (26) that examined asthma in children and adolescents together both reported statistically significant associations, but the evidence was inconclusive. Colen et al. (25) found a significant association between ever versus never being fed human milk and higher risk of asthma from 4 to14 years in the full sample $(\beta$ : 0.261 ; SE: $0.106 ; p<0.05)$, and also among the subsample of children who were siblings ( $\beta$ : 0.237 ; SE: $0.117 ; p<0.05)$. Of note, they also conducted a within-family analysis of siblings with discordant exposures (i.e., 1 sibling was fed human milk and the other was not), and this analysis found no difference in the proportion of siblings fed human milk vs not with asthma from 4 to 14 years, suggesting that residual confounding explained the significant difference observed in the between-family analyses. The case-control study by Rosas-Salazar et al. (26) reported conflicting results. When compared with children and adolescents never fed human milk, the children and adolescents fed human milk <6 months had lower odds of asthma (OR: 0.7; 95\% Cl: 0.5, 1.0; $p=0.04)$. On the other hand, there was a nonsignificant association between being fed human milk $\geq 6$ months and higher odds of asthma that had a wide confidence interval with a lower limit of 1.0 .

It was difficult to determine whether or not the heterogeneous associations found in these two

\footnotetext{
7 United Nations Development Programme. Human Development Report 2014. Sustaining Human Progress: Reducing Vulnerabilities and Building Resilience. New York, 2014
} 
studies was due to the inclusion of adolescents in the samples because evidence in adolescents alone was scant, as described below.

\section{Evidence in adolescents only}

The only study of asthma in adolescents, alone, found nonsignificant associations between being fed human milk 3 weeks to 3 months and $\geq 4$ months vs never and a slightly higher odds of asthma by age 14 years (8).

Table 6. Evidence examining the relationship between never versus ever feeding human milk and asthma in childhood ${ }^{1}$

Article

Study design (study/cohort name when applicable)

Country

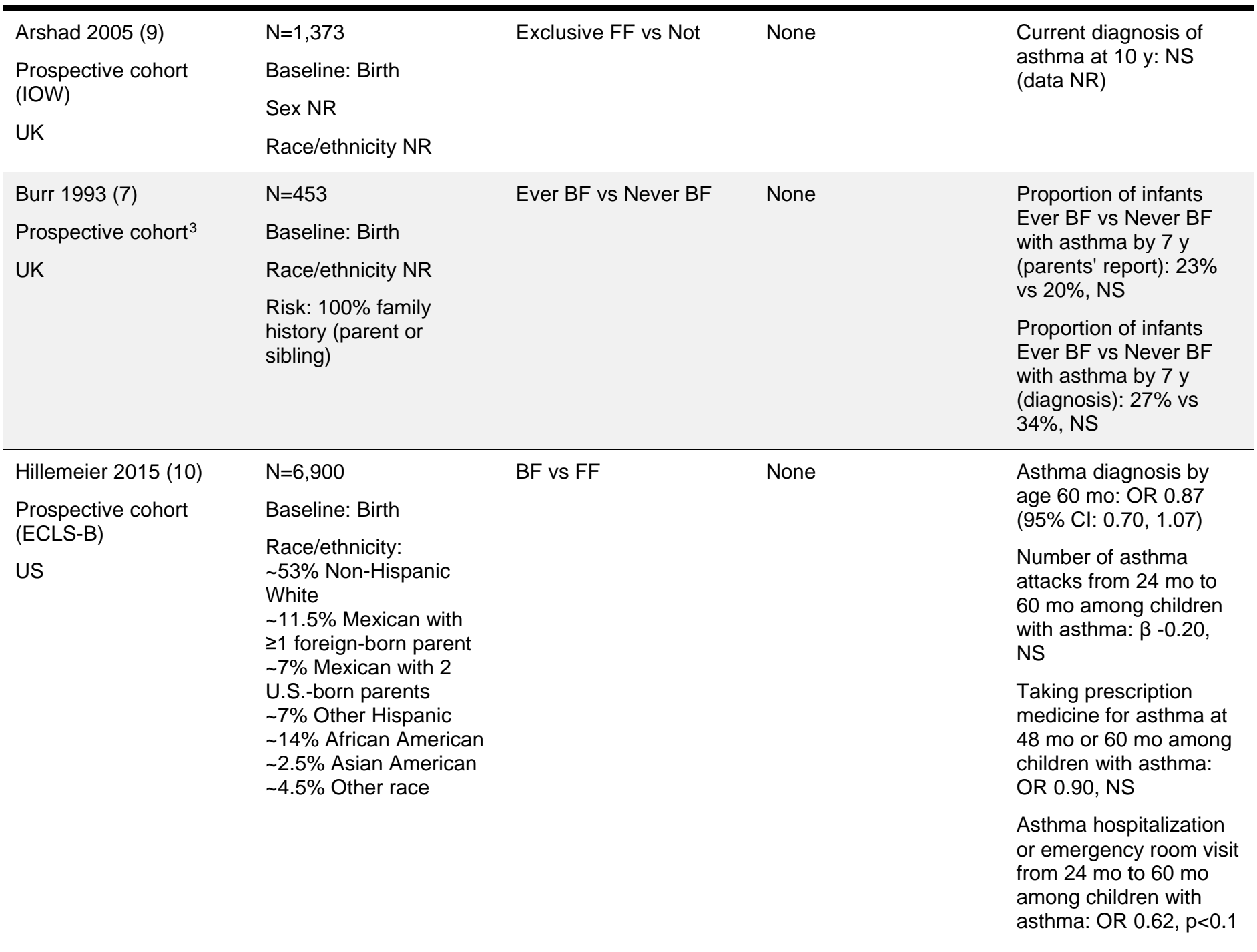

\begin{tabular}{|c|c|c|}
\hline $\begin{array}{l}\text { lever versus ever } \\
\text { eeding human milk } \\
\text { xposure }^{2}\end{array}$ & $\begin{array}{l}\text { Significant } \\
\text { associations with } \\
\text { asthma }\end{array}$ & $\begin{array}{l}\text { Nonsignificant } \\
\text { associations with } \\
\text { asthma }\end{array}$ \\
\hline
\end{tabular}

Notable sample characteristics

$$
\text { exposure }^{2}
$$

\section{asthma} associations with asthma
Current diagnosis of asthma at $10 \mathrm{y}$ : NS (data NR)
Proportion of infants Ever BF vs Never BF (parents' report): 23\%

Proportion of infants Ever BF vs Never BF (diagnosis): $27 \%$ vs Asthma diagnosis by age 60 mo: OR 0.87 (95\% Cl: 0.70, 1.07)

Number of asthma with asthma: $\beta-0.20$

Taking prescription medicine for asthma at

Asthma hospitalization rom 24 mo to 60 mo among children with asthma: OR 0.62, p<0.1 
Article

Study design (study/cohort name when applicable)

\section{Country}

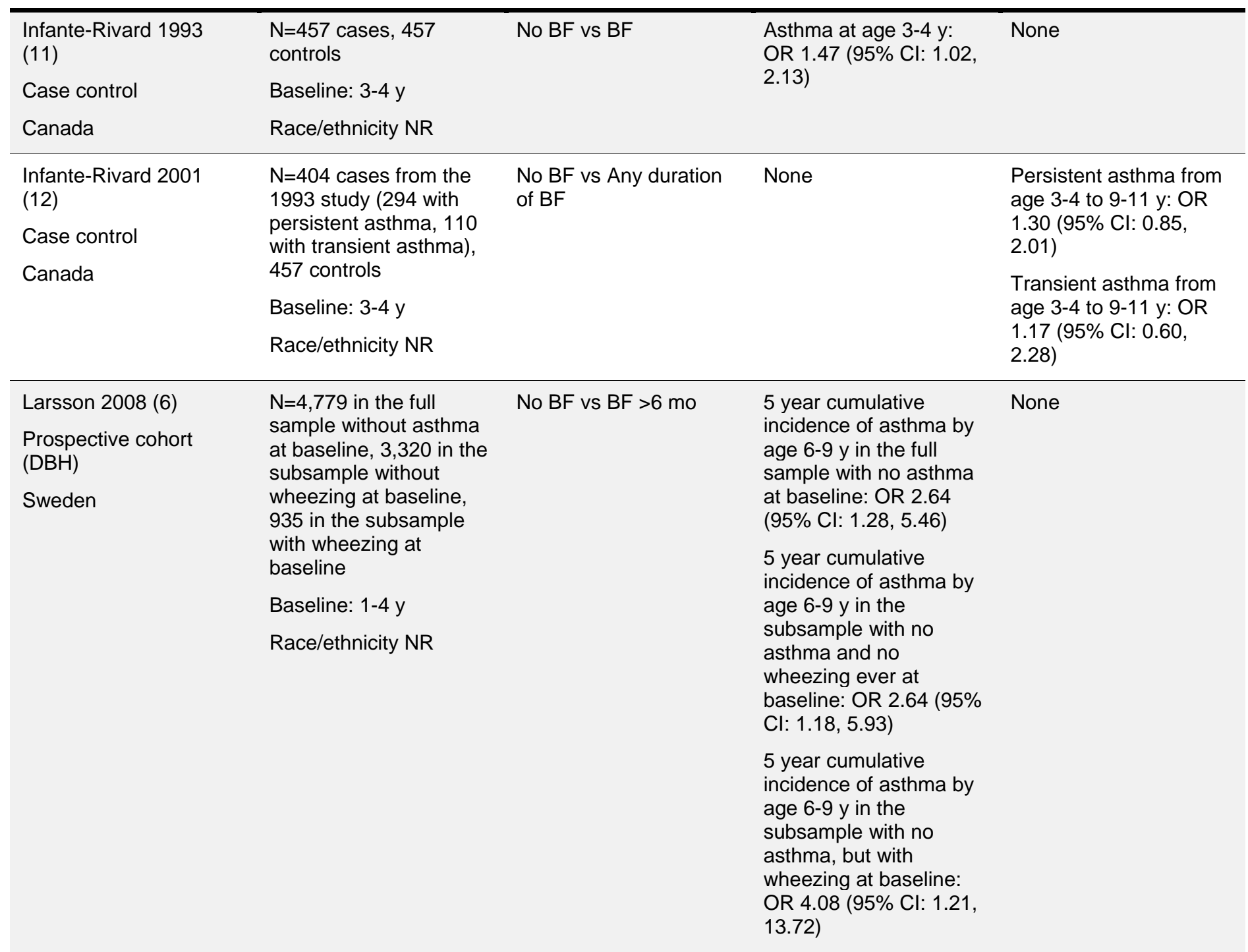

Never versus ever feeding human milk exposure $^{2}$

\section{Significant associations with asthma}

Nonsignificant associations with asthma
Notable sample characteristics 
Article

\section{Study design (study/cohort name when applicable)}

\section{Country}

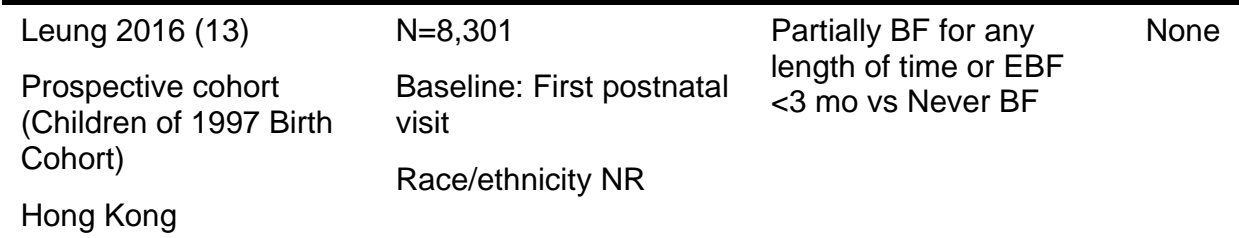

Never versus ever exposure $^{2}$

Notable sample characteristics feeding human milk

\section{Race/ethnicity NR}

\section{Significant associations with asthma}

Nonsignificant associations with asthma
Public hospital admissions for asthma from >3 mo to $12 \mathrm{y}$ : HR 1.12 (95\% Cl: 0.87 . 1.43)

Public hospital admissions for asthma from >3 mo to $2 \mathrm{y}$ : HR 0.63 (95\% Cl: 0.32, 1.25)

Public hospital admissions for asthma from $>2$ y to $6 \mathrm{y}$ : HR 1.14 (95\% Cl: 0.85, 1.53)

Public hospital admissions for asthma from $>3$ mo to $6 \mathrm{y}$ : HR 1.03 (95\% Cl: 0.79, 1.35)

Public hospital admissions for asthma from $>6$ y to $12 \mathrm{y}$ : HR 0.87 (95\% Cl: 0.41, 1.83)

Public hospital admissions for asthma from >3 mo to $12 \mathrm{y}$ : HR 1.27 (95\% Cl: 0.82, 1.98)

Public hospital admissions for asthma from >3 mo to $2 \mathrm{y}$ : HR 1.69 (95\% Cl: 0.64, 4.50)

Public hospital admissions for asthma from $>2$ y to $6 \mathrm{y}$ : HR 1.11 (95\% Cl: 0.64, 1.90)

Public hospital admissions for asthma from $>3$ mo to $6 \mathrm{y}$ : HR 1.19 (95\% Cl: 0.74, 1.92)

Public hospital admissions for asthma from $>6$ y to $12 \mathrm{y}$ : HR 1.05 (95\% Cl: 0.35, 3.19) 
Article

Study design (study/cohort name when applicable)

Country
Notable sample characteristics
Never versus ever feeding human milk exposure $^{2}$
Significant associations with asthma
Nonsignificant associations with asthma

\begin{tabular}{|c|c|c|c|c|}
\hline \multirow{4}{*}{$\begin{array}{l}\text { Maas } 2011(14) \\
\text { Prospective } \text { cohort }^{3} \\
\text { (PREVASC) } \\
\text { Netherlands }\end{array}$} & $\begin{array}{l}\mathrm{N}=387 \\
\text { Baseline: Birth } \\
\text { Race/ethnicity NR }\end{array}$ & BF 1-11 wk vs BF 0 wk & None & \multirow[t]{2}{*}{$\begin{array}{l}\text { Allergic asthma at } 6 \mathrm{y} \text { : } \\
\text { OR } 0.385(95 \% \mathrm{Cl} \text { : } \\
0.145,1.003)\end{array}$} \\
\hline & \multirow{3}{*}{ Race/ethnicity NR } & & & \\
\hline & & BF $12-25$ wk vs BF 0 wk & $\begin{array}{l}\text { Allergic asthma at } 6 \text { y: } \\
\text { OR } 0.247(95 \% \mathrm{Cl} \text { : } \\
0.093,0.655)\end{array}$ & None \\
\hline & & $\mathrm{BF} \geq 26 \mathrm{wk}$ vs $\mathrm{BF} 0 \mathrm{wk}$ & None & $\begin{array}{l}\text { Allergic asthma at } 6 \mathrm{y} \text { : } \\
\text { OR } 0.523(95 \% \mathrm{Cl} \text { : } \\
0.187,1.458)\end{array}$ \\
\hline \multirow{6}{*}{$\begin{array}{l}\text { Martel } 2009 \text { (15) } \\
\text { Nested case control } \\
\text { Canada }\end{array}$} & $\begin{array}{l}\mathrm{N}=745 \text { cases, } 833 \\
\text { controls }\end{array}$ & $\mathrm{BF}<6 \mathrm{mo}$ vs No BF & \multirow{5}{*}{$\begin{array}{l}\text { Asthma in childhood } \\
\text { (max. age } 10 \mathrm{y}): \text { OR } \\
0.70(95 \% \mathrm{Cl}: 0.53 \\
0.92)\end{array}$} & \multirow[t]{5}{*}{ None } \\
\hline & Baseline: Birth & & & \\
\hline & Sex NR & & & \\
\hline & Race/ethnicity NR & & & \\
\hline & $\begin{array}{l}\text { Risk: } 85 \% \text { family history } \\
\text { (mothers) }\end{array}$ & & & \\
\hline & & $\mathrm{BF} \geq 6 \mathrm{mo}$ vs No BF & None & $\begin{array}{l}\text { Asthma in childhood } \\
\text { (max. age } 10 \text { y): OR } \\
0.77(95 \% \mathrm{Cl}: 0.57 \\
1.03)\end{array}$ \\
\hline \multirow{3}{*}{$\begin{array}{l}\text { Midodzi } 2010 \text { (16) } \\
\text { Prospective cohort } \\
\text { (NLSCY ECD) }\end{array}$} & $N=8,499$ & BF 0-3 mo vs Never BF & None & \multirow{3}{*}{$\begin{array}{l}\text { Asthma at } 2 \text { to } 5 \text { y: HR } \\
0.85(95 \% \mathrm{Cl}: 0.70 \text {, } \\
1.00)\end{array}$} \\
\hline & Baseline: <2 y & & & \\
\hline & \multirow{2}{*}{ Race/ethnicity NR } & & & \\
\hline & & BF $>3$ mo vs Never BF & $\begin{array}{l}\text { Asthma at } 2 \text { to } 5 \mathrm{y}: \mathrm{HR} \\
0.82(95 \% \mathrm{Cl}: 0.69 \\
0.97)\end{array}$ & None \\
\hline Mihrshahi 2007 (17) & $N=516$ & \multirow[t]{4}{*}{ Ever BF vs Never BF } & \multirow[t]{4}{*}{ None } & \multirow{4}{*}{$\begin{array}{l}\text { Probable current } \\
\text { asthma at } 5 \text { y: OR } 0.59 \\
(95 \% \mathrm{Cl}: 0.30,1.16)\end{array}$} \\
\hline Prospective cohort ${ }^{3}$ & Baseline: Birth & & & \\
\hline & Sex NR & & & \\
\hline Australla & Race/ethnicity NR & & & \\
\hline Miller 2001 (18) & $N=3,883$ & \multirow[t]{4}{*}{ BF vs No BF } & \multirow{4}{*}{$\begin{array}{l}\text { Asthma by } 3 y \text { (maternal } \\
\text { report): OR } 0.68(95 \% \\
\text { Cl: } 0.49,0.97)\end{array}$} & \multirow{4}{*}{$\begin{array}{l}\text { Asthma by } 3 \text { y } \\
\text { (physician report from } \\
\text { retrospective medical } \\
\text { chart review): OR } 0.94 \\
(95 \% \mathrm{Cl}: 0.70,1.26)\end{array}$} \\
\hline Prospective or & Baseline: Birth & & & \\
\hline $\begin{array}{l}\text { retrospective cohort } \\
\text { depending on the } \\
\text { analysis (NMIHS/LF) }\end{array}$ & $\begin{array}{l}\text { Race/ethnicity: } \\
55.0 \% \text { Non-Hispanic } \\
\text { White }\end{array}$ & & & \\
\hline US & $\begin{array}{l}45.0 \% \text { Non-Hispanic } \\
\text { Black }\end{array}$ & & & \\
\hline
\end{tabular}


Article

\section{Study design} (study/cohort name when applicable)

\section{Country}

\begin{tabular}{|c|c|c|c|c|}
\hline \multirow{3}{*}{$\begin{array}{l}\text { Milner } 2004 \text { (5) } \\
\text { Prospective cohort } \\
\text { (NMIHS/LF) } \\
\text { US }\end{array}$} & $N=8,073$ & \multirow[t]{3}{*}{ Ever BF vs Never BF } & \multirow{3}{*}{$\begin{array}{l}\text { Asthma at } 3 \text { y (maternal } \\
\text { report): OR } 0.61(95 \% \\
\mathrm{Cl}: 0.52,0.71)\end{array}$} & \multirow[t]{3}{*}{ None } \\
\hline & Baseline: Birth & & & \\
\hline & $\begin{array}{l}\text { Race/ethnicity: } \\
\text { 51\% Black } \\
46 \% \text { White } \\
\text { 3\% Other }\end{array}$ & & & \\
\hline \multirow{9}{*}{$\begin{array}{l}\text { Nwaru } 2013 \text { (19) } \\
\text { Prospective cohort } \\
\text { (SEATON) } \\
\text { UK }\end{array}$} & $\begin{array}{l}\mathrm{N}=934 \text {, subsamples } \\
\text { with and without family } \\
\text { history of atopy NR }\end{array}$ & \multirow[t]{3}{*}{ Ever BF vs No BF } & \multirow[t]{3}{*}{ None } & $\begin{array}{l}\text { Asthma by } 10 \text { y: OR } \\
0.81 \text { ( } 95 \% \mathrm{Cl}: 0.59 \\
1.13)\end{array}$ \\
\hline & $\begin{array}{l}\text { Baseline: Birth } \\
\text { Race/ethnicity NR }\end{array}$ & & & $\begin{array}{l}\text { Asthma up to age } 10 \text { y } \\
\text { in subsample with no } \\
\text { family history of atopy: } \\
\text { OR } 0.80(95 \% \mathrm{Cl}: 0.42 \text {, } \\
1.55)\end{array}$ \\
\hline & & & & $\begin{array}{l}\text { Asthma up to age } 10 \text { y } \\
\text { in subsample with } \\
\text { family history of atopy: } \\
\text { OR } 0.78 \text { ( } 95 \% \mathrm{Cl}: 0.53 \text {, } \\
1.14)\end{array}$ \\
\hline & & \multirow[t]{3}{*}{$\mathrm{BF}<2.25 \mathrm{mo}$ vs No BF } & \multirow[t]{3}{*}{ None } & $\begin{array}{l}\text { Asthma by } 10 \text { y: OR } \\
0.90 \text { (95\% Cl: } 0.61 \\
1.35)\end{array}$ \\
\hline & & & & $\begin{array}{l}\text { Asthma up to age } 10 \text { y } \\
\text { in subsample with no } \\
\text { family history of atopy: } \\
\text { OR } 1.25(95 \% \mathrm{Cl}: 0.59 \text {, } \\
2.66)\end{array}$ \\
\hline & & & & $\begin{array}{l}\text { Asthma up to age } 10 \text { y } \\
\text { in subsample with } \\
\text { family history of atopy: } \\
\text { OR } 0.77(95 \% \mathrm{Cl}: 0.49 \text {, } \\
1.23)\end{array}$ \\
\hline & & \multirow[t]{3}{*}{$\mathrm{BF} \geq 2.25 \mathrm{mo}$ vs No BF } & \multirow[t]{3}{*}{ None } & $\begin{array}{l}\text { Asthma by } 10 \text { y: OR } \\
0.76(95 \% \mathrm{Cl}: 0.53, \\
1.09)\end{array}$ \\
\hline & & & & $\begin{array}{l}\text { Asthma up to age } 10 \text { y } \\
\text { in subsample with no } \\
\text { family history of atopy: } \\
\text { OR } 0.58(95 \% \mathrm{Cl}: 0.27 \text {, } \\
1.23)\end{array}$ \\
\hline & & & & $\begin{array}{l}\text { Asthma up to age } 10 \text { y } \\
\text { in subsample with } \\
\text { family history of atopy: } \\
\text { OR } 0.77 \text { ( } 95 \% \mathrm{Cl} \text { : } 0.51 \text {, } \\
1.17)\end{array}$ \\
\hline
\end{tabular}

Never versus ever feeding human milk exposure $^{2}$

Significant
associations with
asthma

Significant

Notable sample characteristics
Nonsignificant associations with asthma 


\section{Article}

\section{Study design} (study/cohort name when applicable)

\section{Country}

\begin{tabular}{|c|c|c|c|c|}
\hline & $N=853$ & \multirow[t]{2}{*}{ Never BF vs BF >6 mo } & \multirow[t]{2}{*}{ None } & $\begin{array}{l}\text { Asthma at } 4 \text { y: OR } 1.22 \\
(95 \% \mathrm{Cl}: 0.32,4.63)\end{array}$ \\
\hline $\begin{array}{l}\text { (PASTURE) } \\
\text { Finland, France, } \\
\text { Germany, Switzerland }\end{array}$ & $\begin{array}{l}\text { Baseline: Birth } \\
\text { Race/ethnicity NR }\end{array}$ & & & $\begin{array}{l}\text { Asthma between } 4-6 \text { y: } \\
\text { OR } 0.69 \text { (95\% Cl: } 0.22 \text {, } \\
2.21)\end{array}$ \\
\hline \multirow{5}{*}{$\begin{array}{l}\text { Scholtens } 2009 \text { (21) } \\
\text { Prospective cohort } \\
\text { (PIAMA) } \\
\text { Netherlands }\end{array}$} & \multirow{3}{*}{$\begin{array}{l}\mathrm{N}=3,115 \text { in the full } \\
\text { sample, } 2,238 \text { in the } \\
\text { subsample with non- } \\
\text { allergic mothers, } 877 \text { in } \\
\text { the subsample with } \\
\text { allergic mothers }\end{array}$} & \multirow{5}{*}{$\begin{array}{l}\text { BF 1-16 weeks vs No } \\
\text { BF }\end{array}$} & \multirow[t]{5}{*}{ None } & \multirow{5}{*}{$\begin{array}{l}\text { Asthma at } 8 \text { years: OR } \\
0.82(95 \% \mathrm{Cl}: 0.61, \\
1.09) \\
\text { Chronic asthma by } 8 \\
\text { years: OR } 0.87(95 \% \\
\mathrm{Cl}: 0.62,1.24)\end{array}$} \\
\hline & & & & \\
\hline & & & & \\
\hline & Baseline: Birth & & & \\
\hline & Race/ethnicity NR & & & \\
\hline
\end{tabular}

Never versus ever feeding human milk exposure $^{2}$

Significant associations with asthma

Nonsignificant associations with asthma
Notable sample characteristics
Asthma at $4 \mathrm{y}:$ OR 1.22

Asthma between 4-6 y: OR 0.69 (95\% Cl: 0.22 , 2.21) years: OR 0.87 (95\% the subsample with

Race/ethnicity NR 


\section{Article}

Study design (study/cohort name when applicable)

\section{Country} Notable sample
characteristics
Never versus ever feeding human milk exposure $^{2}$
Significant associations with asthma
Nonsignificant associations with asthma
BF >16 weeks vs No BF Asthma at 3 y: OR $\sim 0.65$ (95\% Cl: $\sim 0.50$, $\sim 0.85$ )

Asthma at $3 \mathrm{y}$ in subsample with nonallergic mothers: OR $\sim 0.70$ (95\% Cl: $\sim 0.50$, $\sim 1.00$ )

Asthma at $3 \mathrm{y}$ in subsample with allergic mothers: OR $\sim 0.55$

(95\% Cl: $\sim 0.35, \sim 0.90$ )

Asthma at 5 y: OR $\sim 0.50$ (95\% Cl: $\sim 0.55$, $\sim 0.90$ )

Asthma at 5 y in subsample with nonallergic mothers: OR $\sim 0.70$ (95\% Cl: $\sim 0.50$, $\sim 1.00$ )

Asthma at 6 y: OR $\sim 0.60$ (95\% Cl: $\sim 0.45$, $\sim 0.80$ )

Asthma at $6 \mathrm{y}$ in subsample with nonallergic mothers: OR $\sim 0.50$ (95\% Cl: $\sim 0.35$, $\sim 0.75$ )

Asthma at $7 \mathrm{y}:$ OR $\sim 0.65$ (95\% Cl: $\sim 0.50$, $\sim 0.90$ )

Asthma at $7 \mathrm{y}$ in subsample with nonallergic mothers: OR $\sim 0.65$ (95\% Cl: $\sim 0.45$, $\sim 0.95)$

Asthma at 8 y: OR 0.57 (95\% Cl: 0.41, 0.80)

Chronic asthma by 8 years: OR 0.65 (95\% $\mathrm{Cl}: 0.44,0.96)$

Asthma at $8 \mathrm{y}$ in subsample with nonallergic mothers: OR $\sim 0.50$ (95\% Cl: $~ 0.35$, $\sim 0.75$ )
Asthma at $4 \mathrm{y}$ : OR

$\sim 0.80$ (95\% Cl: $\sim 0.60$, $\sim 1.05)$

Asthma at $4 \mathrm{y}$ in subsample with nonallergic mothers: OR $\sim 0.75$ (95\% Cl: $\sim 0.55$, 1.10)

Asthma at $4 \mathrm{y}$ in subsample with allergic mothers: OR $\sim 0.85$

(95\% Cl: $\sim 0.50, \sim 1.35)$

Asthma at $5 \mathrm{y}$ in subsample with allergic mothers: OR $\sim 0.60$ (95\% Cl: $\sim 0.40, \sim 1.05$ )

Asthma at $6 \mathrm{y}$ in subsample with allergic mothers: OR $\sim 0.75$

(95\% Cl: $\sim 0.45, \sim 1.30)$

Asthma at $7 \mathrm{y}$ in subsample with allergic mothers: OR $\sim 0.65$ (95\% Cl: $\sim 0.40, \sim 1.10)$

Asthma at $8 \mathrm{y}$ in subsample with allergic mothers: OR $\sim 0.80$ (95\% Cl: $\sim 0.50, \sim 1.35)$ 


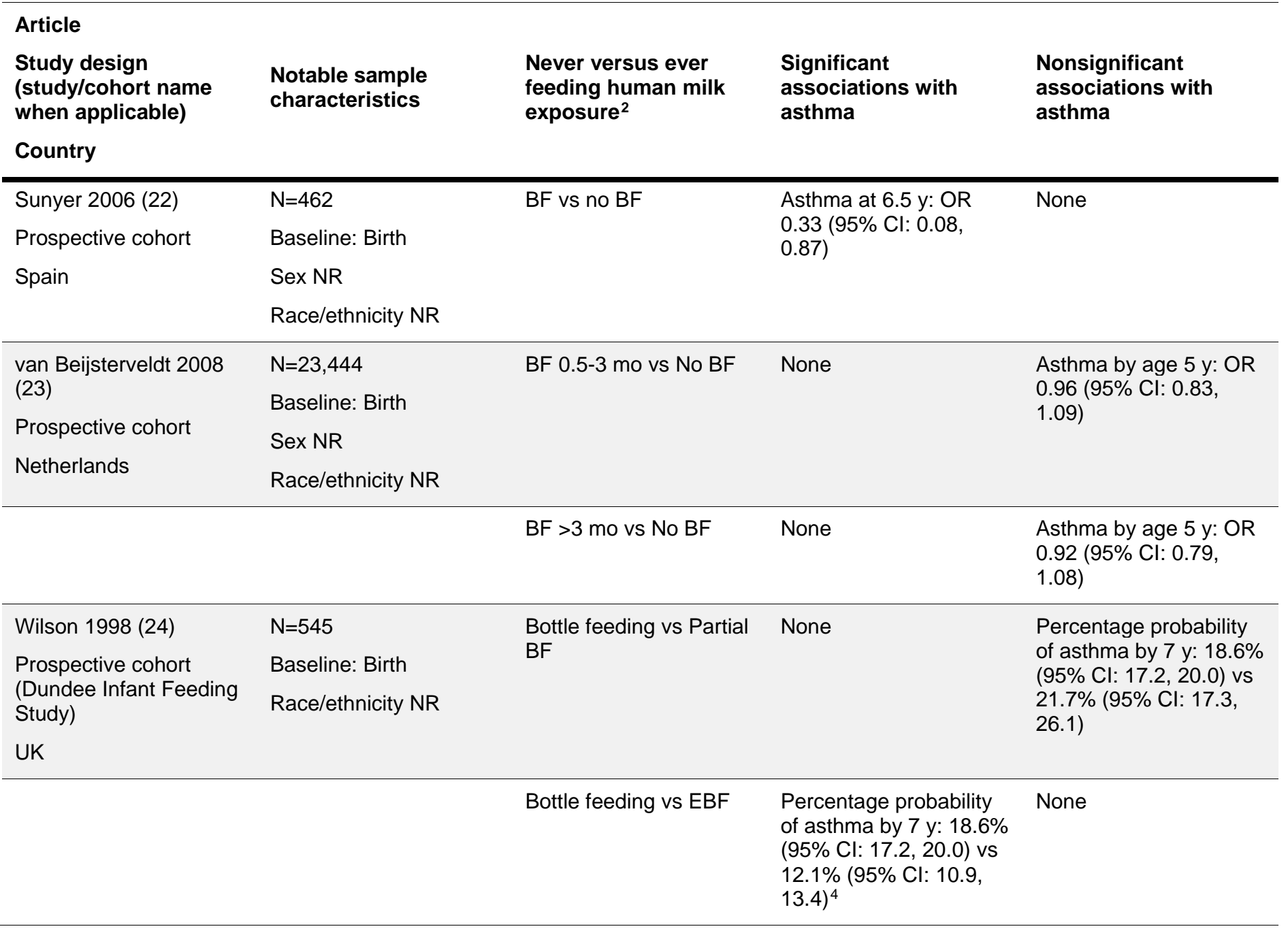


Table 7. Evidence examining the relationship between never versus ever feeding human milk and asthma in childhood and adolescence together ${ }^{1}$

Article

\section{Study design (study/cohort name when applicable)}

Country
Never versus ever feeding human milk exposure $^{2}$

\section{Significant associations with asthma}

BF vs Not BF

Baseline: Birth

Race/ethnicity:

74.49\% Non-Hispanic White

$17.28 \%$ Non-Hispanic

Black

8.23\% Hispanic

Rosas-Salazar 2015

(26)

$\mathrm{N}=509$ cases, 618

controls

Case control

US

\section{Baseline: Mean $10 \mathrm{y}$} (range 6-14)

Race/ethnicity: 100\%

Puerto Rican

\section{$\mathrm{BF}>6$ mo vs No BF \\ Asthma at 6 to 14 years: OR 1.5 (95\% Cl: 1.0, 2.4) \\ BF 0-2 mo vs No BF \\ Asthma at 6 to 14 years: OR $0.6(95 \% \mathrm{Cl}$ : $0.5,0.9$ )}

BF 2-4 mo vs No BF None

None

BF 6-8 mo vs No BF None

BF 8-10 mo vs No BF

None

Asthma at 6 to 14 years: OR 2.9 (95\% Cl:

BF 10-12 mo vs No BF None

BF $>12$ mo vs No BF None $0.3,25.2$ )

Asthma at 6 to 14 years: OR $0.9(95 \% \mathrm{Cl}$ : $0.6,1.3)$

Asthma at 6 to 14 years: OR $0.6(95 \% \mathrm{Cl}$ : $0.2,1.8$ )

Asthma at 6 to 14 years: OR $1.6(95 \% \mathrm{Cl}$ : $0.9,3.0$ )

Asthma at 6 to 14 years: OR $1.5(95 \% \mathrm{Cl}$ : $0.6,3.4$ )

Asthma at 6 to 14 years: OR $1.4(95 \% \mathrm{Cl}$ : $0.6,3.1)$ 


\title{
Table 8. Evidence examining the relationship between never versus ever feeding human milk and asthma in adolescence ${ }^{1}$
}

Article

Study design (study/cohort name when applicable)
Notable sample
characteristics

$\mathrm{N}=4,964$

Baseline: Birth

Race/ethnicity NR

\author{
Never versus ever \\ feeding human milk \\ exposure ${ }^{2}$
}

\author{
Significant \\ associations with \\ asthma
}

\author{
Nonsignificant \\ associations with \\ asthma
}

\section{Country}

\author{
Burgess 2006 (8) \\ Prospective cohort \\ (Mater University of \\ Queensland Study of \\ Pregnancy)
}

$\mathrm{BF} \geq 4 \mathrm{mo}$ vs No BF
None
Asthma by 14 y: OR 1.03 (95\% Cl: 0.9, 1.2)
Australia
Asthma by $14 \mathrm{y}$ : OR 1.03 (95\% Cl: 0.9, 1.2)

\begin{abstract}
${ }^{1}$ Abbreviations: $\beta$ - regression coefficient, BF - breastfed/breastfeeding, Cl - confidence interval, CAPS - Childhood Asthma Prevention Study, DBH Dampness in Buildings and Health, EBF - exclusively breastfed/exclusive breastfeeding, ECLS-B - Early Childhood Longitudinal Study Birth Cohort, FF formula fed/formula feeding, HR - hazard ratio, mo - months, NLSCY ECD - Canadian National Longitudinal Study of Children and Youth Early Childhood Development Cohort, NMIHS/LF -1988 National Maternal and Infant Health Survey and 1991 Longitudinal Follow-up, NR - not reported, NS not significant, OR - odds ratio, PASTURE - Protection Against Allergy Study in Rural Environments, PIAMA - Prevention and Incidence of Asthma and Mite Allergy, SEATON - Study of Eczema and Asthma to Observe the Influence of Nutrition, $y$ - years
\end{abstract}

${ }^{2}$ Exposures, as defined by the authors of the studies included in the body of evidence, which address never versus ever feeding human milk or vice versa

${ }^{3}$ The cohort was sampled from an RCT however the data of interest for this SR are unrelated to randomization

${ }^{4}$ Study authors stated that there were no differences between feeding groups but the confidence intervals do not overlap 


\section{Research recommendations}

Studies need to be designed and conducted to examine topics where there are gaps in evidence or limited evidence; this includes the relationships between never versus ever being fed human milk and food allergies, allergic rhinitis, and atopic dermatitis throughout the lifespan, and asthma in adolescence and adulthood. In addition, it would be beneficial to have more research with representative U.S. samples to confirm current evidence.

Infant-feeding research will continue to rely on observational designs, because of ethical issues related to randomizing infant to be fed less or no human milk; however, researchers should endeavor to minimize bias through sound research design and conduct. In general, infant-feeding researchers should:

- Move toward collecting data consistently using valid and reliable methods

- Increase the precision with which they define infant-feeding variables

- Incorporate effect modification into their study design whenever possible in case different biological or environmental characteristics modify the impact of infant feeding on the outcomes

- Assess baseline differences in critical confounding variables between comparison groups, and make statistical adjustments as necessary

- Address temporality and reverse causality when outcomes are measured from birth to 24 months 


\section{Included articles}

1. Ivakhnenko, O S, Nyankovskyy, S L. Effect of the specific infant formula mixture of oligosaccharides on local immunity and development of allergic and infectious disease in young children: Randomized study. Pediatria Polska 2013;88(5):398-404.

2. Grimshaw KE, Maskell J, Oliver EM, Morris RC, Foote KD, Mills EN, Roberts G, Margetts BM. Introduction of complementary foods and the relationship to food allergy. Pediatrics 2013;132(6):e1529-38.

3. Host, A. Importance of the first meal on the development of cow's milk allergy and intolerance. Allergy Proc 1991;12(4):227-32.

4. McGowan EC, Bloomberg GR, Gergen PJ, Visness CM, Jaffee KF, Sandel M, O'Connor G, Kattan M, Gern J, Wood RA. Influence of early-life exposures on food sensitization and food allergy in an inner-city birth cohort. J Allergy Clin Immunol 2015;135(1):171-8.

5. Milner JD, Stein DM, McCarter R, Moon RY. Early infant multivitamin supplementation is associated with increased risk for food allergy and asthma. Pediatrics 2004;114(1):27-32.

6. Larsson, M, Hagerhed E, L, Sigsgaard, T, Janson, S, Sundell, J, et al. Incidence rates of asthma, rhinitis and eczema symptoms and influential factors in young children in Sweden. Acta Paediatr 2008;97(9):1210-5.

7. Burr, M L, Limb, E S, Maguire, M J, Amarah, L, Eldridge, B A, et al. Infant feeding, wheezing, and allergy: a prospective study. Arch Dis Child 1993;68(6):724-8.

8. Burgess, S W, Dakin, C J, O'Callaghan, M J. Breastfeeding does not increase the risk of asthma at 14 years. Pediatrics 2006;117(4):e787-92.

9. Arshad SH, Kurukulaaratchy RJ, Fenn M, Matthews S. Early life risk factors for current wheeze, asthma, and bronchial hyperresponsiveness at 10 years of age. Chest 2005;127(2):502-8.

10. Hillemeier MM, Landale NS, Oropesa RS. Asthma in US Mexican-Origin Children in Early Childhood: Differences in Risk and Protective Factors by Parental Nativity. Acad Pediatr 2015;15(4):421-9.

11. Infante R, C. Childhood asthma and indoor environmental risk factors. Am J Epidemiol 1993;137(8):834-44.

12. Infante R, C, Amre, D, Gautrin, D, Malo, J L. Family size, day-care attendance, and breastfeeding in relation to the incidence of childhood asthma. Am J Epidemiol 2001;153(7):653-8.

13. Leung JY, Kwok MK, Leung GM, Schooling CM. Breastfeeding and childhood hospitalizations for asthma and other wheezing disorders. Ann Epidemiol 2016;26(1):21-7 e1-3.

14. Maas, T, Dompeling, E, Muris, J W, Wesseling, G, Knottnerus, J A, et al. Prevention of asthma in genetically susceptible children: a multifaceted intervention trial focussed on feasibility in general practice. Pediatr Allergy Immunol 2011;22(8):794-802.

15. Martel, M J, Rey, E, Malo, J L, Perreault, S, Beauchesne, M F, et al. Determinants of the incidence of childhood asthma: a two-stage case-control study. Am J Epidemiol 2009;169(2):195-205.

16. Midodzi, W K, Rowe, B H, Majaesic, C M, Saunders, L D, Senthilselvan, A. Early life factors associated with incidence of physician-diagnosed asthma in preschool children: results from the Canadian Early Childhood Development cohort study. J Asthma 2010;47(1):7-13.

17. Mihrshahi, S, Ampon, R, Webb, K, Almqvist, C, Kemp, A S, et al. The association between infant feeding practices and subsequent atopy among children with a family history of asthma. Clin Exp Allergy 2007;37(5):671-9.

18. Miller, J E. Predictors of asthma in young children: does reporting source affect our conclusions? Am J Epidemiol 2001;154(3):245-50. 
19. Nwaru, B I, Craig, L C, Allan, K, Prabhu, N, Turner, S W, et al. Breastfeeding and introduction of complementary foods during infancy in relation to the risk of asthma and atopic diseases up to 10 years. Clin Exp Allergy 2013;43(11):1263-73.

20. Orivuori, L, Loss, G, Roduit, C, Dalphin, J C, Depner, M, et al. Soluble immunoglobulin A in breast milk is inversely associated with atopic dermatitis at early age: the PASTURE cohort study. Clin Exp Allergy 2014;44(1):102-12.

21. Scholtens, S, Wijga, A H, Brunekreef, B, Kerkhof, M, Hoekstra, M O, et al. Breast feeding, parental allergy and asthma in children followed for 8 years. The PIAMA birth cohort study. Thorax 2009;64(7):604-9.

22. Sunyer, J, Torrent, M, Garcia E, R, Ribas F, N, Carrizo, D, et al. Early exposure to dichlorodiphenyldichloroethylene, breastfeeding and asthma at age six. Clin Exp Allergy 2006;36(10):1236-41.

23. van Beijsterveldt TC, Boomsma DI. An exploration of gene-environment interaction and asthma in a large sample of 5-year-old Dutch twins. Twin Res Hum Genet 2008;11(2):143-9.

24. Wilson, A C, Forsyth, J S, Greene, S A, Irvine, L, Hau, C, et al. Relation of infant diet to childhood health: seven year follow up of cohort of children in Dundee infant feeding study. BMJ 1998;316(7124):21-5.

25. Colen CG, Ramey DM. Is breast truly best? Estimating the effects of breastfeeding on longterm child health and wellbeing in the United States using sibling comparisons. Social Science \& Medicine 2014;109:55-65.

26. Rosas-Salazar C, Forno E, Brehm JM, Han YY, Acosta-Perez E, Cloutier MM, Wakefield DB, Alvarez M, Colon-Semidey A, Canino G, et al. Breastfeeding duration and asthma in Puerto Rican children. Pediatr Pulmonol 2015;50(6):527-34.

27. Burr, M L, Miskelly, F G, Butland, B K, Merrett, T G, Vaughan W, E. Environmental factors and symptoms in infants at high risk of allergy. J Epidemiol Community Health 1989;43(2):125-32.

28. Chuang $\mathrm{CH}$, Hsieh WS, Chen YC, Chang PJ, Hurng BS, Lin SJ, Chen PC. Infant feeding practices and physician diagnosed atopic dermatitis: a prospective cohort study in Taiwan. Pediatr Allergy Immunol 2011;22(1 Pt 1):43-9.

29. Harris, J M, Cullinan, P, Williams, H C, Mills, P, Moffat, S, et al. Environmental associations with eczema in early life. Br J Dermatol 2001;144(4):795-802.

30. Howie, P W, Forsyth, J S, Ogston, S A, Clark, A, Florey, C. Protective effect of breastfeeding against infection... this article originally appeared in the British Medical Journal, V. 300. Reproduced with permission. Breastfeeding Review 1990;2(1):7-15 9p.

31. Mallet, E, Henocq, A. Long-term prevention of allergic diseases by using protein hydrolysate formula in at-risk infants. J Pediatr 1992;121(5 Pt 2):S95-100.

32. Miskelly, F G, Burr, M L, Vaughan W, E, Fehily, A M, Butland, B K, et al. Infant feeding and allergy. Arch Dis Child 1988;63(4):388-93.

33. Morales, E, Garcia E, R, Guxens, M, Guerra, S, Mendez, M, et al. Effects of prolonged breastfeeding and colostrum fatty acids on allergic manifestations and infections in infancy. Clin Exp Allergy 2012;42(6):918-28.

34. Parazzini F, Cipriani S, Zinetti C, Chatenoud L, Frigerio L, Amuso G, Ciammella M, Di Landro A, Naldi L. Perinatal factors and the risk of atopic dermatitis: a cohort study. Pediatr Allergy Immunol 2014;25(1):43-50.

35. Rothenbacher, D, Weyermann, M, Beermann, C, Brenner, H. Breastfeeding, soluble CD14 concentration in breast milk and risk of atopic dermatitis and asthma in early childhood: birth cohort study. Clin Exp Allergy 2005;35(8):1014-21.

36. Sariachvili, M, Droste, J, Dom, S, Wieringa, M, Vellinga, A, et al. Is breast feeding a risk factor for eczema during the first year of life? Pediatr Allergy Immunol 2007;18(5):410-7. 
37. Snijders, B E, Thijs, C, Dagnelie, P C, Stelma, F F, Mommers, M, et al. Breast-feeding duration and infant atopic manifestations, by maternal allergic status, in the first 2 years of life (KOALA study). J Pediatr 2007;151(4):347-51, 51 e1-2.

38. Snijders, B E, Thijs, C, Kummeling, I, Penders, J, van den B, P A. Breastfeeding and infant eczema in the first year of life in the KOALA birth cohort study: a risk period-specific analysis. Pediatrics 2007;119(1):e137-41.

39. Snijders BE, Thijs C, van Ree R, van den Brandt PA. Age at first introduction of cow milk products and other food products in relation to infant atopic manifestations in the first 2 years of life: the KOALA Birth Cohort Study. Pediatrics 2008;122(1):e115-22.

40. Turati F, Bertuccio P, Galeone C, Pelucchi C, Naldi L, Bach JF, La Vecchia C, Chatenoud L. Early weaning is beneficial to prevent atopic dermatitis occurrence in young children. Allergy 2016.

41. Bergmann, R L, Diepgen, $T$ L, Kuss, O, Bergmann, K E, Kujat, J, et al. Breastfeeding duration is a risk factor for atopic eczema. Clin Exp Allergy 2002;32(2):205-9.

42. Purvis, D J, Thompson, J M, Clark, P M, Robinson, E, Black, P N, et al. Risk factors for atopic dermatitis in New Zealand children at 3.5 years of age. Br J Dermatol 2005;152(4):742-9.

43. Sariachvili M, Droste J, Dom S, Wieringa M, Hagendorens M, Stevens W, van Sprundel M, Desager K, Weyler J. Early exposure to solid foods and the development of eczema in children up to 4 years of age. Pediatr Allergy Immunol 2010;21(1 Pt 1):74-81.

44. Zutavern A, von Mutius E, Harris J, Mills P, Moffatt S, White C, Cullinan P. The introduction of solids in relation to asthma and eczema. Archives of Disease in Childhood 2004;89(4):303-8. 


\section{ANALYTIC FRAMEWORK}

The analytic framework (Figure 1) illustrates the overall scope of the systematic review, including the population, exposures, comparators, and outcomes of interest. It also includes definitions of key terms and lists critical confounding variables. This is the analytic framework for the systematic review conducted to examine the relationship between never versus ever feeding human milk and food allergies, allergic rhinitis, atopic dermatitis, and asthma.

\section{Figure 1: Analytic framework}

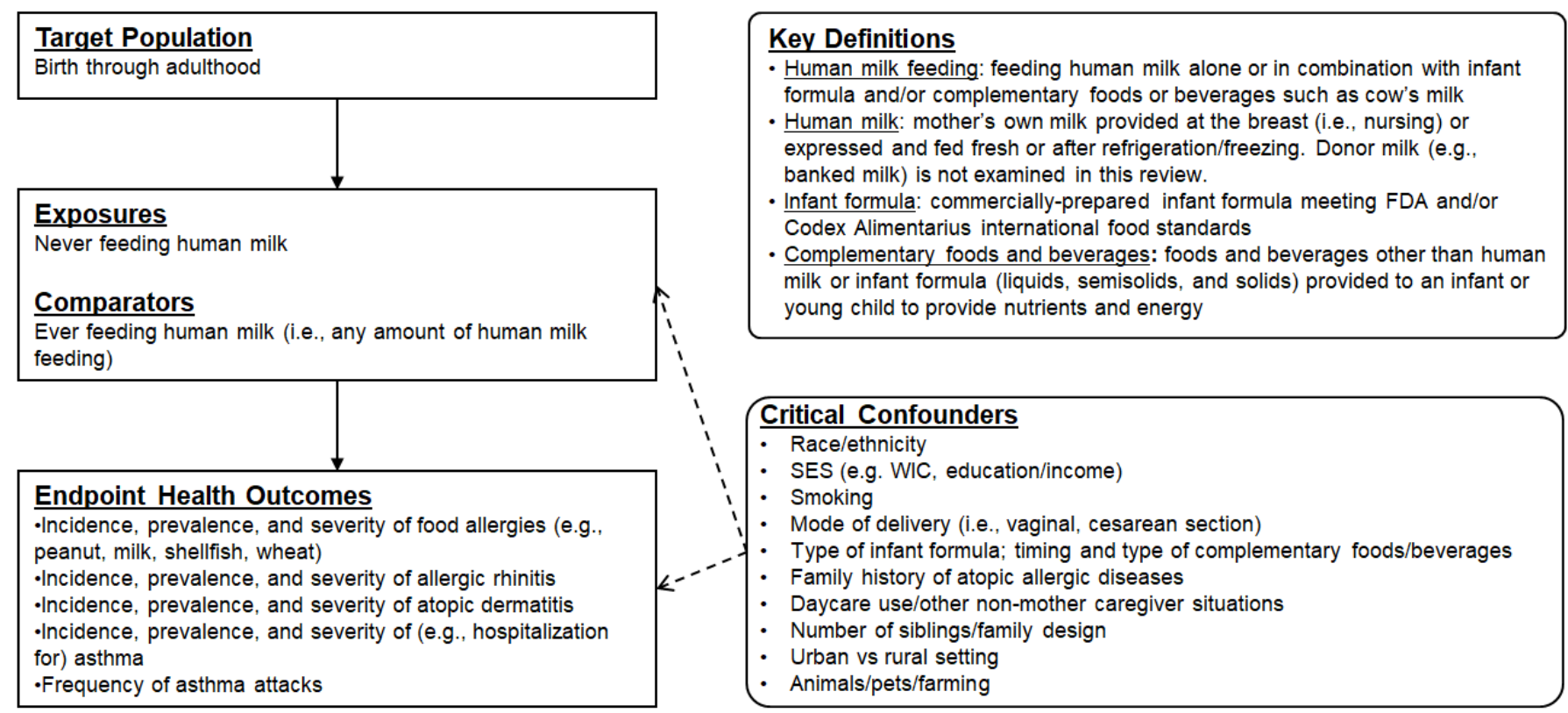

\section{SEARCH PLAN AND RESULTS}

\section{Inclusion and exclusion criteria}

The inclusion and exclusion criteria (Table 9) are a set of characteristics to determine which studies will be included or excluded in the systematic review. This table provides the inclusion and exclusion criteria for the systematic review question: What is the relationship between never versus ever feeding human milk and food allergies, allergic rhinitis, atopic dermatitis, and asthma? 
Table 9. Inclusion and exclusion criteria

Category Inclusion Criteria Exclusion Criteria

\begin{tabular}{|c|c|c|}
\hline \multirow[t]{6}{*}{ Study design } & Randomized controlled trials & Cross-sectional studies \\
\hline & Non-randomized controlled trials & Before-and-after studies \\
\hline & Prospective cohort studies & Uncontrolled studies \\
\hline & Retrospective cohort studies & Narrative reviews \\
\hline & Case-control studies & Systematic reviews \\
\hline & & Meta-analyses \\
\hline Publication status & Published in peer-reviewed journals & $\begin{array}{l}\text { Grey literature, including unpublished data, } \\
\text { manuscripts, reports, abstracts, and conference } \\
\text { proceedings }\end{array}$ \\
\hline Language & Published in English & Published in languages other than English \\
\hline Date range & Published from 1980-December $2015^{8}$ & Published prior to 1980 \\
\hline Intervention/exposure & Never feeding human milk & $\begin{array}{l}\text { Feeding human milk (e.g., very short-term or token } \\
\text { breastfeeding) }\end{array}$ \\
\hline Comparator & $\begin{array}{l}\text { Ever feeding human milk (i.e., any duration/amount } \\
\text { of human milk feeding) }\end{array}$ & \\
\hline \multirow{3}{*}{$\begin{array}{l}\text { Source of foods, } \\
\text { beverages, or } \\
\text { nutrients }\end{array}$} & \multirow{3}{*}{$\begin{array}{l}\text { Human milk: mothers' own milk (MOM), that is, } \\
\text { human milk at the breast (i.e., nursing) or } \\
\text { expressed and fed fresh or after } \\
\text { refrigeration/freezing } \\
\text { Infant formula: commercially-prepared infant } \\
\text { formula meeting FDA }{ }^{9} \text { and/or Codex Alimentarius }{ }^{10} \\
\text { international food standards }\end{array}$} & $\begin{array}{l}\text { Human milk from third parties (e.g., banked/donor } \\
\text { milk) }\end{array}$ \\
\hline & & $\begin{array}{l}\text { Infant formulas that are not commercially-prepared } \\
\text { or that do not meet FDA and/or Codex Alimentarius }\end{array}$ \\
\hline & & international food standards \\
\hline \multirow[t]{5}{*}{ Outcomes } & $\begin{array}{l}\text { Incidence, prevalence, and severity of food } \\
\text { allergies (e.g., peanut, milk, shellfish, wheat) }\end{array}$ & \\
\hline & $\begin{array}{l}\text { Incidence, prevalence, and severity of allergic } \\
\text { rhinitis }\end{array}$ & \\
\hline & $\begin{array}{l}\text { Incidence, prevalence, and severity of atopic } \\
\text { dermatitis }\end{array}$ & \\
\hline & $\begin{array}{l}\text { Incidence, prevalence, and severity of (e.g., } \\
\text { hospitalization for) asthma }\end{array}$ & \\
\hline & Frequency of asthma attacks & \\
\hline Study setting & $\begin{array}{l}\text { Countries listed as Very High or High on the } 2014 \\
\text { Human Development Index }{ }^{11}\end{array}$ & $\begin{array}{l}\text { Countries listed as Medium or Low on the } 2014 \\
\text { Human Development Index }\end{array}$ \\
\hline
\end{tabular}

8 In 1980 the Infant Formula Act was passed, and December 2015 was when the literature search occurred

${ }^{9}$ U.S. Food and Drug Administration. Version 19 December 2013. Internet: https://www.fda.gov/Food/GuidanceRegulation/GuidanceDocumentsRegulatorylnformation/InfantFormula/ucm13611 8.htm\#manufacture (accessed March 23, 2018).

${ }^{10}$ Food and Agriculture Organization of the United Nations. World Health Organization. Codex Alimentarius. International Food Standards. Standard for infant formula and formulas for special medical purposes intended for infants. Codex Stan 72-1981. 2007.

${ }^{11}$ United Nations Development Programme. Human Development Report 2014. Sustaining Human Progress: Reducing Vulnerabilities and Building Resilience. New York, 2014. 


\begin{tabular}{|c|c|c|}
\hline Category & Inclusion Criteria & Exclusion Criteria \\
\hline \multirow[t]{3}{*}{ Study participants } & Human participants & \multirow{2}{*}{$\begin{array}{l}\text { Non-human participants (e.g., animal studies, in } \\
\text { vitro studies) }\end{array}$} \\
\hline & Males & \\
\hline & Females & $\begin{array}{l}\text { Hospitalized patients, not including birth and } \\
\text { immediate post-partum hospitalization of healthy } \\
\text { babies }\end{array}$ \\
\hline \multirow[t]{3}{*}{$\begin{array}{l}\text { Age of study } \\
\text { participants }\end{array}$} & $\begin{array}{l}\text { Exposure age: infants ( } 0-12 \text { months), toddlers (12- } \\
24 \text { months) }\end{array}$ & \multirow{3}{*}{$\begin{array}{l}\text { Outcome age: infants ( } 0-12 \text { months) and toddlers } \\
\text { ( } 12-24 \text { months) for asthma outcomes, only, as } \\
\text { outcomes in this age group may represent transient } \\
\text { recurrent wheeze }{ }^{12}\end{array}$} \\
\hline & $\begin{array}{l}\text { Outcome age: infants }(0-12 \text { months })^{\star} \text {, toddlers }(12- \\
24 \text { months })^{\star}, \text { children }(2-12 \text { years }), \text { adolescents } \\
\text { (13-18 years) adults (19 years and older) }\end{array}$ & \\
\hline & $\begin{array}{l}\text { *Examine outcomes from birth to } 24 \text { months for } \\
\text { food allergies, allergic rhinitis, and atopic dermatitis, } \\
\text { only }\end{array}$ & \\
\hline Size of study groups & $\begin{array}{l}\text { Studies with } \geq 30 \text { participants per study group or a } \\
\text { power analysis indicating that the study is } \\
\text { appropriately powered for the outcome(s) of interest }\end{array}$ & $\begin{array}{l}\text { Studies with }<30 \text { participants per study group with } \\
\text { no power analysis indicating that the study is } \\
\text { appropriately powered for the outcome(s) of interest }\end{array}$ \\
\hline \multirow{4}{*}{$\begin{array}{l}\text { Health status of study } \\
\text { participants }\end{array}$} & Studies done in generally healthy populations & $\begin{array}{l}\text { Studies that exclusively enroll participants with a } \\
\text { disease or the health outcome of interest }\end{array}$ \\
\hline & $\begin{array}{l}\text { Studies done in populations where infants were full } \\
\text { term ( } \geq 37 \text { and } 0 / 7 \text { weeks gestational age) }\end{array}$ & \multirow{2}{*}{$\begin{array}{l}\text { Studies done in hospitalized participants (except for } \\
\text { birth and immediate post-partum hospitalization of } \\
\text { healthy babies) or malnourished participants }\end{array}$} \\
\hline & \multirow{2}{*}{$\begin{array}{l}\text { Studies done in populations with elevated chronic } \\
\text { disease risk, or that enroll some participants with a } \\
\text { disease or with the health outcome of interest }\end{array}$} & \\
\hline & & $\begin{array}{l}\text { Studies of exclusively pre-term babies (gestational } \\
\text { age }<37 \text { weeks), exclusively babies that have low } \\
\text { birth weight }(<2500 \mathrm{~g}) \text { and/or exclusively babies that } \\
\text { are small for gestational age }\end{array}$ \\
\hline
\end{tabular}

\section{Search terms and electronic databases used}

\section{PubMed}

- Dates searched: Dec 4, 2015 and March 28, 2016 to refine/limit search terms and remove pub type indexing

- Search Terms:

(breast feeding[mh] OR breastfeeding[tiab] OR breast feeding*[tiab] OR breastfeeding*[tiab] OR breastfed[tiab] OR breast-fed[tiab] OR breastfeed*[tiab] OR "breast feed"[tiab]) OR (Milk, human[mh] OR "breast milk"[tiab] OR breast-milk[tiab] OR "human milk"[tiab] OR "mother's milk"[tiab] OR breastmilk[tiab]) OR (Bottle feeding[mh] OR bottle feeding*[tiab] OR "bottle feeding"[tiab] OR bottle-feeding*[tiab] OR bottle-fed[tiab] OR "bottle fed"[tiab])

\section{NOT ((aids[ti] AND "Acquired Immunodeficiency Syndrome"[Mesh]) OR hiv[ti] OR HIVIAIDS[ti] OR human immunodefic*[ti] OR Acquired Immunodefic*[ti] OR "low birth}

\footnotetext{
${ }^{12}$ Stein RT, Holberg CJ, Morgan WJ, Wright AL, Lombardi E, Taussig L, Martinez FD. Peak flow variability, methacholine responsiveness and atopy as markers for detecting different wheezing phenotypes in childhood. Thorax 1997;52(11):946-52.
} 
weight"[ti] OR Ibw[ti] OR vlbw[ti] OR elbw[ti] OR pcb[ti] OR pcbs[ti] OR Polychlorinated Biphenyl*[ti] OR Polychlorobiphenyl Compound*[ti] OR dioxin*[ti] OR (breast[ti] AND (tumor*[ti] OR tumour*[ti] OR cancer*[ti] OR carcinoma*[ti] OR disease*[ti]))) NOT (breastfeed*[ti] OR breastfed*[ti] OR feed*[ti] OR fed[ti] OR milk[ti])

NOT (editorial[ptyp] OR comment[ptyp] OR news[ptyp] OR letter[ptyp] OR review[ptyp] OR systematic[sb])

Limiters; Engl/humans; 1980-

\section{Embase}

- $\quad$ Date searched: Dec 5, 2015

- Search Terms:

'bottle feeding'/exp OR 'bottle feeding':ab,ti OR 'bottle feedings':ab,ti OR 'bottle fed':ab,ti OR bottle* NEAR/3 feed* AND [english]/lim AND [humans]/lim AND [1980-2015]/py OR 'breast milk'/exp OR 'human milk':ab,ti OR 'breast milk':ab,ti OR breastmilk:ab,ti OR mother* NEAR/2 milk OR 'maternal milk':ab,ti AND [english]/lim AND [humans]/lim AND [1980-2015]/py OR 'breast feeding'/exp OR breastfeed*:ab,ti OR 'breast feed':ab,ti OR 'breast feeding':ab,ti OR breastfed:ab,ti OR 'breast fed':ab,ti OR feeding NEAR/3 breast AND [english]/lim AND [humans]/lim AND [1980-2015]/py

\section{Using Citation manager to filter out title key words:}

NOT (aids AND "Acquired Immunodeficiency Syndrome") OR hiv OR HIVIAIDS OR human immunodefic* OR Acquired Immunodefic* OR "low birth weight" OR Ibw OR vlbw OR elbw OR pcb OR pcbs OR Polychlorinated Biphenyl* OR Polychlorobiphenyl Compound* OR dioxin* OR (breast AND (tumor* OR tumour* OR cancer* OR carcinoma* OR disease*)) OR preterm OR premature

\section{CINAHL}

- Date searched: Dec 8, 2015

- Search Terms:

(MH "Breast Feeding+" OR breast-fed OR "breast fed" OR breastfeeding OR breast feeding OR breast-fed) OR MH "Milk, Human" OR "Human Milk" OR "Breast Milk" OR Breastmilk OR breast-milk OR ((maternal OR mother*) n3 milk) OR (MH "Bottle Feeding") OR "bottle feeding" OR (bottle n3 feed*) OR bottle-feeding OR bottle-feedings OR "bottle fed" OR "bottle-fed")

\section{Using Citation manager to filter out title key words:}

NOT (aids AND "Acquired Immunodeficiency Syndrome") OR hiv OR HIVIAIDS OR human immunodefic* OR Acquired Immunodefic* OR "low birth weight" OR lbw OR vlbw OR elbw OR pcb OR pcbs OR Polychlorinated Biphenyl* OR Polychlorobiphenyl Compound* OR dioxin* OR (breast AND (tumor* OR tumour* OR cancer* OR carcinoma* OR disease*)) OR preterm OR premature

\section{Cochrane}

- Date searched: Dec 8, 2015

- Search Terms:

"Breast Feeding"OR breast-fed OR "breast fed" OR breastfeeding OR "breast feeding" OR 
"breast feed" OR "breast feeds" OR breast-feed OR breast-feeds OR (breast NEAR/3 feed*) OR "human milk" OR "breast milk" OR breastmilk OR "mother's milk" OR "maternal milk" OR ((mother* OR maternal OR donor* OR donate*) NEAR/3 milk) OR "Bottle feeding" OR "bottle feedings" OR "bottle-feeding" OR "bottle-feedings" OR (bottle NEAR/3 feed*)

Using Citation manager to filter out title key words:

NOT (aids AND "Acquired Immunodeficiency Syndrome") OR hiv OR HIVIAIDS OR human immunodefic* OR Acquired Immunodefic* OR "low birth weight" OR Ibw OR vlbw OR elbw OR pcb OR pcbs OR Polychlorinated Biphenyl* OR Polychlorobiphenyl Compound* OR dioxin* OR (breast AND (tumor* OR tumour* OR cancer* OR carcinoma* OR disease*)) OR preterm OR premature 


\section{Figure 2: Flow chart of literature search and screening results}

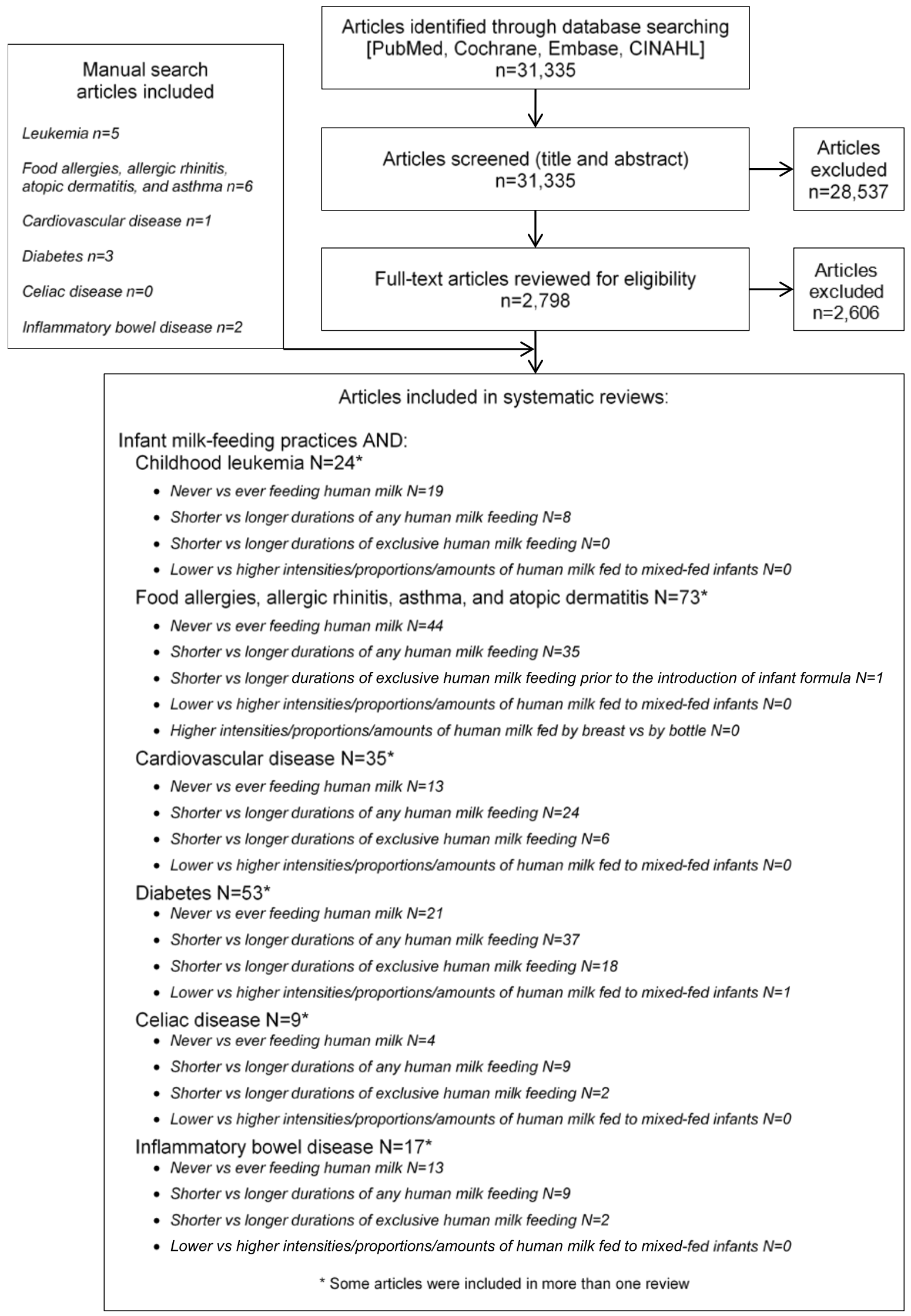


This flow chart illustrates the literature search and screening results for articles examining the relationship between infant milk-feeding practices, including never versus ever feeding human milk, and several outcomes, including food allergies, allergic rhinitis, atopic dermatitis, and asthma. The results of the electronic database searches were screened independently by two NESR analysts in a step-wise manner by reviewing titles and abstracts, and then full text articles to determine which articles met the criteria for inclusion. A manual search was done to ascertain articles not identified through the electronic database search. The systematic review on never versus ever feeding human milk and food allergies, allergic rhinitis, atopic dermatitis, and asthma included 44 articles. 
Table 10. Excluded articles

The table below lists the full-text articles excluded with at least one reason for exclusion, and may not reflect all possible reasons. 
1 Aarts, C.,Kylberg, E.,Hofvander, Y.,Gebre-Medhin, M. Growth under privileged conditions of healthy Swedish infants exclusively breastfed from

Independent variable birth to 4-6 months: a longitudinal prospective study based on daily records of feeding. Acta Paediatr. 2003;92(2):145-51.

2 Abarin, T.,Yan Wu, Y.,Warrington, N.,Lye, S.,Pennell, C.,Briollais, L. The impact of breastfeeding on FTO-related BMI growth trajectories: an Independent variable application to the Raine pregnancy cohort study. Int J Epidemiol. 2012;41(6):1650-60.

3 Abdel-Hafeez, E. H.,Belal, U. S.,Abdellatif, M. Z. M.,Naoi, K.,Norose, K. Breast-feeding protects infantile diarrhea caused by intestinal protozoan Health status infections. Korean Journal of Parasitology. 2013;51(5):519-524.

4 Abdoll, G. S. Report on the nursing bottle caries campaign launched by the Free State Oral Health Services. Sadj. 2001;56(1):32-3.

Study design

5 Abdulmoneim, I.,Al-Ghamdi, S. A. Relationship between breast-feeding duration and acute respiratory infections in infants. Saudi Med J. 2001;22(4):347-50

6 Aberg, N.,Engstrom, I.,Lindberg, U. Allergic diseases in Swedish school children. Acta Paediatr Scand. 1989;78(2):246-52.

Study design

7 Abraham, E. C.,Godwin, J.,Sherriff, A.,Armstrong, J. Infant feeding in relation to eating patterns in the second year of life and weight status in the fourth year. Public Health Nutr. 2012;15(9):1705-14.

Study design

Included for systematic reviews not completed

8 Abuekteish, F.,Alwash, R.,Hassan, M.,Daoud, A. S. Prevalence of asthma and wheeze in primary school children in northern Jordan. Ann Trop Study design Paediatr. 1996;16(3):227-31.

9 Abusaad, Fawzia E.,El-Gilany, Abdel-Hady. Exclusive breastfeeding and infant morbidity in Sakaka City, Saudi Arabia. Middle East Journal of Nursing. 2011;5(6):3-8 6p.

10 Academy of Breastfeeding Medicine. ABM Clinical Protocol \#24: Allergic Proctocolitis in the Exclusively Breastfed Infant. Breastfeed Med. 2011;6(6):435-40.

11 Adgent, M. A.,Hoffman, K.,Goldman, B. D.,Sjodin, A.,Daniels, J. L. Brominated flame retardants in breast milk and behavioural and cognitive development at 36 months. Paediatr Perinat Epidemiol. 2014;28(1):48-57.

12 Adlakha, A. L.,Suchindran, C. M. Factors affecting infant and child mortality. J Biosoc Sci. 1985;17(4):481-96.

Study design

13 Agache, I.,Ciobanu, C. Risk factors and asthma phenotypes in children and adults with seasonal allergic rhinitis. Phys Sportsmed. 2010;38(4):81-6.

14 Agarwal, D. K.,Agarwal, K. N.,Khare, B. B. Study on current status of infant and childhood feeding practices. Indian Pediatr. $1985 ; 22(9): 716$.

15 Agostoni, C. Breast-feeding, human milk, long-chain polyunsaturated fatty acids and development. Dev Med Child Neurol Suppl. 2001;86:8-9.

Study design

16 Agostoni, C.,Fiocchi, A.,Riva, E., Terracciano, L., Sarratud, T.,Martelli, A.,Lodi, F.,D'Auria, E.,Zuccotti, G.,Giovannini, M. Growth of infants with Independent variable IgE-mediated cow's milk allergy fed different formulas in the complementary feeding period. Pediatr Allergy Immunol. 2007;18(7):599-606. Health status 
17 Agostoni, C.,Grandi, F.,Gianni, M. L.,Silano, M.,Torcoletti, M.,Giovannini, M.,Riva, E. Growth patterns of breast fed and formula fed infants in the first 12 months of life: an Italian study. Arch Dis Child. 1999;81(5):395-9.

Included for systematic reviews not completed

Independent variable

Agostoni, C.,Grandi, F.,Scaglioni, S.,Gianni, M. L.,Torcoletti, M.,Radaelli, G.,Fiocchi, A.,Riva, E. Growth pattern of breastfed and nonbreastfed infants with atopic dermatitis in the first year of life. Pediatrics. 2000;106(5):E73.

19 Agostoni, C.,Marangoni, F.,Giovannini, M.,Galli, C.,Riva, E. Prolonged breast-feeding (six months or more) and milk fat content at six months are Group size associated with higher developmental scores at one year of age within a breast-fed population. Adv Exp Med Biol. 2001;501:137-41.

20 Agostoni, C.,Marangoni, F.,Lammardo, A. M.,Giovannini, M.,Riva, E.,Galli, C. Breastfeeding duration, milk fat composition and developmental indices at 1 year of life among breastfed infants. Prostaglandins Leukot Essent Fatty Acids. 2001;64(2):105-9.

21 Agostoni, C.,Riva, E.,Bellu, R.,Trojan, S.,Luotti, D.,Giovannini, M. Effects of diet on the lipid and fatty acid status of full-term infants at 4 months J Am Coll Nutr. 1994;13(6):658-64.

22 Agostoni, C.,Trojan, S.,Bellu, R.,Riva, E.,Giovannini, M. Neurodevelopmental quotient of healthy term infants at 4 months and feeding practice: the role of long-chain polyunsaturated fatty acids. Pediatr Res. 1995;38(2):262-6.

systematic reviews not completed

Group size 1990;116(5):805-9.

24 Agras, W. S.,Kraemer, H. C.,Berkowitz, R. I.,Korner, A. F.,Hammer, L. D. Does a vigorous feeding style influence early development of adiposity?. J Pediatr. 1987;110(5):799-804.

25 Agre, F. The relationship of mode of infant feeding and location of care to frequency of infection. Am J Dis Child. 1985;139(8):809-11.

Dependent variable

26

Ahn, C. H.,MacLean, W. C., Jr. Growth of the exclusively breast-fed infant. Am J Clin Nutr. 1980;33(2):183-92.

Study design,

Independent variable

27 Ahn, S. K.,Kam, S.,Chun, B. Y. Incidence of and factors for self-reported fragility fractures among middle-aged and elderly women in rural Korea: Age An 11-year follow-up study. Journal of Preventive Medicine and Public Health. 2014;47(6):289-297.

28 Ajetunmobi, O. M.,Whyte, B.,Chalmers, J.,Tappin, D. M.,Wolfson, L.,Fleming, M.,MacDonald, A.,Wood, R.,Stockton, D. L. Breastfeeding is associated with reduced childhood hospitalization: evidence from a Scottish Birth Cohort (1997-2009). J Pediatr. 2015;166(3):620-5 e4.

Independent variable

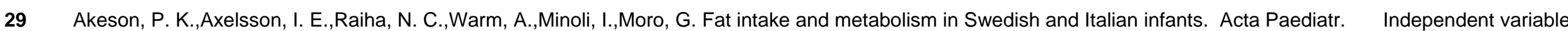
2000;89(1):28-33.

30 Akeson, P. M.,Axelsson, I. E.,Raiha, N. C. Growth and nutrient intake in three- to twelve-month-old infants fed human milk or formulas with varying protein concentrations. J Pediatr Gastroenterol Nutr. 1998;26(1):1-8.

31 Akeson, P. M.,Axelsson, I. E.,Raiha, N. C.. Plasma lipids and apolipoproteins in breastfed and formula-fed Swedish infants. Acta Paediatr. 1999;88(1):1-6.
Study design

Dependent variable 
Al Mamun, A.,O'Callaghan, M. J.,Williams, G. M.,Najman, J. M.,Callaway, L.,Mclntyre, H. D.. Breastfeeding is protective to diabetes risk in young Dependent variable adults: a longitudinal study. Acta Diabetol. 2015;52(5):837-44.

34 Al-Abbad, A. A.,Bella, H. Diarrhoea in the under-fives in a Saudi semiurban community. Tropical and Geographical Medicine. 1990;42(3):233- Study design 237.

35 al-Ali, F. M.,Hossain, M. M.,Pugh, R. N. The associations between feeding modes and diarrhoea among urban children in a newly developed country. Public Health. 1997;111(4):239-43.

36 Alaluusua, S.,Lukinmaa, P. L.,Koskimies, M.,Pirinen, S.,Holtta, P.,Kallio, M.,Holttinen, T.,Salmenpera, L. Developmental dental defects associated with long breast feeding. Eur J Oral Sci. 1996;104(5-6):493-7.

37 Alaluusua, S.,Myllarniemi, S.,Kallio, M.,Salmenpera, L.,Tainio, V. M. Prevalence of caries and salivary levels of mutans streptococci in 5-year-old children in relation to duration of breast feeding. Scand J Dent Res. 1990;98(3):193-6.

Independent variable

38 Alam, S.,Ahmad, S. A.,Kumar, S. Dietary regimen for persistent diarrhea in infants under four months. Indian Pediatr. 2001;38(4):396-400.

\section{systematic reviews not}

completed

Country

39 Al-Atawi, M. S.,Al-Alwan, I. A.,Al-Mutair, A. N.,Tamim, H. M.,Al-Jurayyan, N. A. Epidemiology of nutritional rickets in children. Saudi J Kidney Dis Study design Transpl. 2009;20(2):260-5.

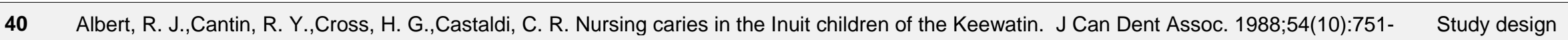

41 al-Dashti, A. A.,Williams, S. A.,Curzon, M. E. Breast feeding, bottle feeding and dental caries in Kuwait, a country with low-fluoride levels in the Study design water supply. Community Dent Health. 1995;12(1):42-7.

42 Alderete, T. L.,Autran, C.,Brekke, B. E.,Knight, R.,Bode, L.,Goran, M. I.,Fields, D. A. Associations between human milk oligosaccharides and

Independent variable infant body composition in the first 6 mo of life. Am J Clin Nutr. 2015;102(6):1381-8.

43 Alexander, D. A. Breastfeeding study needs to be viewed in context..'Breastfeeding may increase the risk of asthma and allergies' (Specialty News Bulletin, December 2002). RN. 2003;66(4):10-10 1p.

44 Alexander, E. S.,Martin, L. J.,Collins, M. H.,Kottyan, L. C., Sucharew, H.,He, H.,Mukkada, V. A., Succop, P. A.,Abonia, J. P.,Foote, H.,Eby, M. D., Grotjan, T. M.,Greenler, A. J.,Dellon, E. S.,Demain, J. G.,Furuta, G. T.,Gurian, L. E.,Harley, J. B., Hopp, R. J.,Kagalwalla, A., Kaul, A.,Nadeau, K. C.,Noel, R. J.,Putnam, P. E.,von Tiehl, K. F.,Rothenberg, M. E. Twin and family studies reveal strong environmental and weaker genetic cues explaining heritability of eosinophilic esophagitis. J Allergy Clin Immunol. 2014;134(5):1084-1092 e1.

45 Alexy, U.,Kersting, M.,Sichert-Hellert, W.,Manz, F.,Schoch, G. Energy intake and growth of 3- to 36-month-old German infants and children. Ann Nutr Metab. 1998;42(2):68-74. 
49 Alho, O. P.,Laara,Oja, H. How should relative risk estimates for acute otitis media in children aged less than 2 years be perceived?. J Clin Independent variable Epidemiol. 1996;49(1):9-14.

50 Ali, M. B.,Ghenghesh, K. S.,Aissa, R. B.,Abuhelfaia, A.,Dufani, M. Etiology of childhood diarrhea in Zliten, Libya. Saudi Med J. 2005;26(11):1759-65. status

51 Al-Jassir, M. S.,El-Bashir, B. M.,Moizuddin, S. K. Surveillance of infant feeding practices in Riyadh city. Ann Saudi Med. 2004;24(2):136-40.

53 Allen, N. B.,Lewinsohn, P. M.,Seeley, J. R. Prenatal and perinatal influences on risk for psychopathology in childhood and adolescence. Dev Study design Psychopathol. 1998;10(3):513-29.

$54 \quad$ Allergy in your baby. Aust Fam Physician. 1986;15(2):176, 178.

55 Alliet, P.,Scholtens, P.,Raes, M.,Hensen, K.,Jongen, H.,Rummens, J. L.,Boehm, G.,Vandenplas, Y. Effect of prebiotic galacto-oligosaccharide, $\quad$ Group size long-chain fructo-oligosaccharide infant formula on serum cholesterol and triacylglycerol levels. Nutrition. 2007;23(10):719-23.

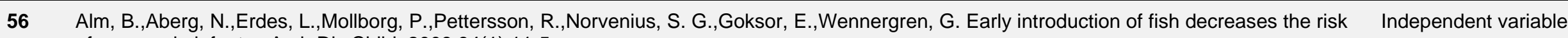
of eczema in infants. Arch Dis Child. 2009;94(1):11-5.

57 Alm, B.,Erdes, L.,Mollborg, P.,Pettersson, R.,Norvenius, S. G.,Aberg, N.,Wennergren, G. Neonatal antibiotic treatment is a risk factor for early wheezing. Pediatrics. 2008;121(4):697-702.

58 Alm, B.,Norvenius, S. G.,Wennergren, G.,Lagercrantz, H.,Helweg-Larsen, K.,Irgens, L. M. Living conditions in early infancy in Denmark, Norway Study design and Sweden 1992-95: results from the Nordic Epidemiological SIDS study. Acta Paediatr. 2000;89(2):208-14.

59 Alm, B.,Wennergren, G.,Norvenius, S. G.,Skjaerven, R.,Lagercrantz, H.,Helweg-Larsen, K.,Irgens, L. M. Breast feeding and the sudden infant death syndrome in Scandinavia, 1992-95. Arch Dis Child. 2002;86(6):400-2.

Included for systematic reviews not completed

Study design Brazil. Ann Trop Paediatr. 1999;19(3):257-62.

61 Almquist-Tangen, G.,Dahlgren, J.,Roswall, J.,Bergman, S.,Alm, B. Milk cereal drink increases BMI risk at 12 and 18 months, but formula does not. Acta Paediatr. 2013;102(12):1174-9. 
63 Alper, C. M.,Winther, B.,Hendley, J. O.,Doyle, W. J. Cytokine polymorphisms predict the frequency of otitis media as a complication of rhinovirus and RSV infections in children. Eur Arch Otorhinolaryngol. 2009;266(2):199-205.

Included for systematic reviews not completed

64 Alper, C. M.,Winther, B.,Mandel, E. M.,Hendley, J. O.,Doyle, W. J. Rate of concurrent otitis media in upper respiratory tract infections with specific viruses. Arch Otolaryngol Head Neck Surg. 2009;135(1):17-21.

Study design

65 Al-Qaoud, N.,Prakash, P. Breastfeeding and obesity among Kuwaiti preschool children. Medical Principles and Practice. $2009 ; 18(2): 111-117$.

Study design

66 Al-Qaoud, N.,Prakash, P. 'Can breastfeeding and its duration determine the overweight status of Kuwaiti children at the age of 3-6 years?'. Eur J Study design Clin Nutr. 2009;63(8):1041-3.

67 Al-Shehri, M. A.,Sadeq, A.,Quli, K. Bronchiolitis in Abha, Southwest Saudi Arabia: viral etiology and predictors for hospital admission. West Afr J Health status Med. 2005;24(4):299-304.

68 Al-Shehri, S. S.,Knox, C. L.,Liley, H. G.,Cowley, D. M.,Wright, J. R.,Henman, M. G.,Hewavitharana, A. K.,Charles, B. G.,Shaw, P. N.,Sweeney, E. L.,Duley, J. A. Breastmilk-Saliva Interactions Boost Innate Immunity by Regulating the Oral Microbiome in Early Infancy. PLoS One.

Independent variable 2015;10(9):e0135047.

69 Althaus BW. Growth patterns of Hispanic and Caucasian children: Texas Woman's University; 1999.

Study design

70 Altinkaynak, S.,Selimoglu, M. A.,Turgut, A.,Kilicaslan, B.,Ertekin, V. Breast-feeding duration and childhood acute leukemia and lymphomas in a sample of Turkish children. Journal of Pediatric Gastroenterology and Nutrition. 2006;42(5):568-572.

71 Altucher, K.,Rasmussen, K. M.,Barden, E. M.,Habicht, J. P. Predictors of improvement in hemoglobin concentration among toddlers enrolled in Study design the Massachusetts WIC Program. J Am Diet Assoc. 2005;105(5):709-15.

72 Alvarado, B. E.,Zunzunegui, M. V.,Delisle, H.,Osorno, J. Growth trajectories are influenced by breast-feeding and infant health in an afrocolombian community. J Nutr. 2005;135(9):2171-8.

73 Alvarado, R.,Zepeda, A.,Rivero, S.,Rico, N.,Lopez, S.,Diaz, S. Integrated maternal and infant health care in the postpartum period in a poor neighborhood in Santiago, Chile. Stud Fam Plann. 1999;30(2):133-41.

74 Alves, J. G.,Figueira, F.,Nacul, L. C. Hospital induced malnutrition in infants: prevention by relactation. Indian Pediatr. 1999;36(5):484-7.

75 Amador, M.,Hermelo, M. P.,Canetti, J. E.,Consuegra, E. Adolescent mothers: do they breast-feed less?. Acta Paediatr Hung. 1992;32(3):26985.

76 Amador-Licona, N.,Martinez-Cordero, C.,Guizar-Mendoza, J. M.,Malacara, J. M.,Hernandez, J.,Alcala, J. F. Catch-up growth in infants born small for gestational age--a longitudinal study. J Pediatr Endocrinol Metab. 2007;20(3):379-86. 
79 Amigo, H.,Bustos, P.,Leone, C.,Radrigán, M. E. Community and international nutrition: Growth deficits in Chilean school children. Journal of Nutrition. 2001;131(2):251-254.

80 Ananthakrishnan, S.,Bhat, B. V.,Puri, R. K.,Srinivasan, S. Loose stools in the early neonatal period. Indian Pediatr. 1992;29(8):1005-9.

Country

81 Ancona, J.,Shaker, C. S.,Puhek, J.,Garland, J. S. Improving outcomes through a developmental approach to nipple feeding. J Nurs Care Qual. Study design 1998;12(5):1-4.

82 Andersen, G. E. Changes in plasma lipoproteins from first day to third week of human life. Prog Clin Biol Res. 1985;188:87-91.

Study design

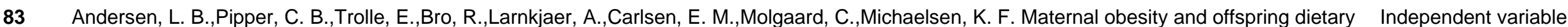
patterns at 9 months of age. Eur J Clin Nutr. 2015;69(6):668-75.

84 Anderson, G. H.,Morson-Pasut, L. A.,Bryan, H.,Cleghorn, G.,Tanaka, P.,Yeung, D.,Zimmerman, B. Age of introduction of cow's milk to infants. J Study design Pediatr Gastroenterol Nutr. 1985;4(5):692-8.

85 Anderson, J. E.,Marks, J. S.,Park, T. K. Breast-feeding, birth interval, and infant health. Pediatrics. 1984;74(4 Pt 2):695-701.

Study design

86 Anderson, J.,Hayes, D.,Chock, L. Characteristics of overweight and obesity at age two and the association with breastfeeding in Hawai'i Women, Infants, and Children (WIC) participants. Matern Child Health J. 2014;18(10):2323-31.

Included for systematic reviews not completed

\section{Anderson, K. The sweet and sour of pediatric caries. CDS Rev. 2001;94(7):16-9.}

Study design

88 Anderson, L. J.,Parker, R. A.,Strikas, R. A.,Farrar, J. A.,Gangarosa, E. J.,Keyserling, H. L., Sikes, R. K. Day-care center attendance and hospitalization for lower respiratory tract illness. Pediatrics. 1988;82(3):300-308.

Included for systematic reviews not completed

89 Anderson, P. O.,Valdes, V. Variation of milk intake over time: clinical and pharmacokinetic implications. Breastfeed Med. 2015;10(3):142-4.

Study design Dependent variable

90 Andreev, A.,Arjas, E. Acute middle ear infection in small children: a Bayesian analysis using multiple time scales. Lifetime Data Anal. Study design 1998;4(2):121-37

91 Andres, A.,Casey, P. H.,Cleves, M. A.,Badger, T. M. Body fat and bone mineral content of infants fed breast milk, cow's milk formula, or soy formula during the first year of life. J Pediatr. 2013;163(1):49-54.

92 Andres, A. Cleves, M. A. Bellando, J. B. Pivik, R. T Casey, P. H.,Badger, T. M. Developmental status of 1-year-old infants fed breast milk, cow's milk formula, or soy formula. Pediatrics. 2012;129(6):1134-40.

93 Anfield, L. Nutrition in the first year. Midwife Health Visit Community Nurse. 1985;21(5):161-4.

Study design 
95 Angulo, N.,de Szarvas, S. B.,Guevara, H.,Mathison, Y.,González, D.,Hernández, A. Lifestyle of a group of obese children located in Valencia Salus. 2014;18(1):25-31.

96 Anholm, P. C. Breastfeeding: a preventive approach to health care in infancy. Issues Compr Pediatr Nurs. 1986;9(1):1-10.

Language

Study design

97 Aniansson, G.,Alm, B.,Andersson, B.,Hakansson, A.,Larsson, P.,Nylen, O.,Peterson, H.,Rigner, P.,Svanborg, M.,Sabharwal, H.,et al.,. A prospective cohort study on breast-feeding and otitis media in Swedish infants. Pediatr Infect Dis J. 1994;13(3):183-8.

Included for

systematic reviews not

completed

98 Annamalay, A. A.,Khoo, S. K.,Jacoby, P.,Bizzintino, J.,Zhang, G.,Chidlow, G.,Lee, W. M.,Moore, H. C.,Harnett, G. B.,Smith, D. W.,Gern, J.

E.,LeSouef, P. N.,Laing, I. A.,Lehmann, D. Prevalence of and risk factors for human rhinovirus infection in healthy aboriginal and non-aboriginal

Dependent variable Western Australian children. Pediatr Infect Dis J. 2012;31(7):673-9.

99 Ansari-Moghaddam, A.,Sadeghi-Bojd, S.,Imani, M.,Movahedinia, S.,Pourrashidi, A.,Mohammadi, M. A multivariate analysis of factors associated with infant mortality in South-East of Iran. J Pak Med Assoc. 2014;64(10):1123-6.

Included for

systematic reviews not completed

100 Apostolopoulos, K.,Xenelis, J.,Tzagaroulakis, A.,Kandiloros, D.,Yiotakis, J.,Papafragou, K. The point prevalence of otitis media with effusion among school children in Greece. International Journal of Pediatric Otorhinolaryngology. 1998;44(3):207-214.

Study design

101 Apps, J. R.,Beattie, R. M. Cow's milk allergy in children. BMJ. 2009;339:b2275.

Study design

102 Araujo, C. L., Victora, C. G.,Hallal, P. C.,Gigante, D. P. Breastfeeding and overweight in childhood: evidence from the Pelotas 1993 birth cohort study. Int J Obes (Lond). 2006;30(3):500-6.

Included for systematic reviews not completed

103 Araujo, D. S.,Marquezin, M. C.,Barbosa, T. S.,Gaviao, M. B.,Castelo, P. M. Evaluation of masticatory parameters in overweight and obese children. Eur J Orthod. 2015.

104 Arica, S.,Arica, V.,Dag, H.,Kaya, A.,Hatipoglu, S.,Fenercioglu, A.,Karatekin, G. Serum zinc levels in children of 0-24 months diagnosed with pneumonia admitted to our clinic. International Journal of Clinical and Experimental Medicine. 2011;4(3):227-233.

Study design

105 Arimond, M.,Daelmans, B.,Dewey, K. Indicators for feeding practices in children. Lancet. 2008;371(9612):541-2.

Independent variable Health status

Study design

106 Aris, I. M.,Soh, S. E.,Tint, M. T.,Saw, S. M.,Rajadurai, V. S.,Godfrey, K. M.,Gluckman, P. D.,Yap, F.,Chong, Y. S.,Lee, Y. S. Associations of infant milk feed type on early postnatal growth of offspring exposed and unexposed to gestational diabetes in utero. Eur J Nutr. 2015.

Included for systematic reviews not completed

Study design

107 Arlette, J. P. Zinc deficiency in children. Int J Dermatol. 1982;21(8):447-8. 
109 Arnon, S. S.,Damus, K., Thompson, B.,Midura, T. F.,Chin, J. Protective role of human milk against sudden death from infant botulism. J Pediatr. Group size 1982;100(4):568-73.

110 Arora, N. K.,Bhan, M. K. Nutritional management of acute diarrhea. Indian J Pediatr. 1991;58(6):763-7.

111 Arshad, S. H.,Bateman, B.,Matthews, S. M. Primary prevention of asthma and atopy during childhood by allergen avoidance in infancy: a Independent variable randomised controlled study. Thorax. 2003;58(6):489-93. Isle of Wight prevention study. J Allergy Clin Immunol. 2007;119(2):307-13. 113 Arton M. Breast feeding--a life-saver in the Third World. Midwives Chron. 1985;98:200-1.

Independent variable

114 Aryayev, N.,Kukushkin, V. The perinatal risk factors of sudden infant death syndrome. Perinatology. 2002;4(3):125-133.

No full text

115 Aryayev, N.,Kukushkin, V.,Nepomyashcha, V. The significance of ante- and perinatal periods for formation of risk of sudden infant death syndrome. Ginekologia polska. 2001;72(12):931-939.

Included for systematic reviews not completed

116 Asaka, A.,Imaizumi, Y.,Inouye, E. Analysis of multiple births in Japan. V. Effects of gestational age, maternal age and other factors on growth Study design rate of weight in twins. Jinrui Idengaku Zasshi. 1981;26(2):83-90.

117 Ascher, H.,Krantz, I.,Rydberg, L.,Nordin, P.,Kristiansson, B. Influence of infant feeding and gluten intake on coeliac disease. Arch Dis Child. 1997;76(2):113-7.

118 Asha Bai, P. V.,Leela, M.,Subramaniam, V. R. Adequacy of breast milk for optimal growth of infants. Trop Geogr Med. 1980;32(2):158-62.

\section{Country}

119 Ashraf, A. P.,Eason, N. B.,Kabagambe, E. K.,Haritha, J.,Meleth, S.,McCormick, K. L. Dietary iron intake in the first 4 months of infancy and the Study design development of type 1 diabetes: A pilot study. Diabetology and Metabolic Syndrome. 2010;2(1).

120 Askie, L.,Martin, A.,Espinoza, D.,Campbell, K.,Daniels, L. A.,Hesketh, K.,Margarey, A., Rissel, C., Taylor, B., Taylor, R.,Wen, L. M.,Baur, L. A. What does the EPOCH (early prevention of obesity in childhood) prospective meta-analysis tell us about early life obesity prevention?. Obesity research \& clinical practice. 2014;8:3-4.

121 Assuncao, M. L.,Ferreira, H. S.,Coutinho, S. B.,Santos, L. M.,Horta, B. L. Protective effect of breastfeeding against overweight can be detected as early as the second year of life: a study of children from one of the most socially-deprived areas of Brazil. J Health Popul Nutr. 2015;33(1):8591.

122 Astarita, C.,Harris, R. I.,de Fusco, R.,Franzese, A.,Biscardi, D.,Mazzacca, F. R.,Altucci, P. An epidemiological study of atopy in children. Clin Allergy. 1988;18(4):341-50. 
124 Atladottir, H.,Thorsdottir, I. Energy intake and growth of infants in Iceland-a population with high frequency of breast-feeding and high birth weight. Eur J Clin Nutr. 2000;54(9):695-701.

125 Auerbach, K. G.,Renfrew, M. J.,Minchin, M. Infant feeding comparisons: a hazard to infant health?. J Hum Lact. 1991;7(2):63-8.

126 Auestad, N.,Halter, R.,Hall, R. T.,Blatter, M.,Bogle, M. L.,Burks, W.,Erickson, J. R.,Fitzgerald, K. M.,Dobson, V.,Innis, S. M.,Singer, L. T.,Montalto, M. B.,Jacobs, J. R.,Qiu, W.,Bornstein, M. H. Growth and development in term infants fed long-chain polyunsaturated fatty acids: a double-masked, randomized, parallel, prospective, multivariate study. Pediatrics. 2001;108(2):372-81.

127 Auestad, N.,Montalto, M. B.,Hall, R. T.,Fitzgerald, K. M.,Wheeler, R. E.,Connor, W. E.,Neuringer, M.,Connor, S. L.,Taylor, J. A.,Hartmann, E. E. Visual acuity, erythrocyte fatty acid composition, and growth in term infants fed formulas with long chain polyunsaturated fatty acids for one year. Ross Pediatric Lipid Study. Pediatr Res. 1997;41(1):1-10.

128 Auestad, N.,Scott, D. T.,Janowsky, J. S.,Jacobsen, C.,Carroll, R. E.,Montalto, M. B.,Halter, R., Qiu, W.,Jacobs, J. R.,Connor, W. E., Connor, S. L.,Taylor, J. A.,Neuringer, M.,Fitzgerald, K. M.,Hall, R. T. Visual, cognitive, and language assessments at 39 months: a follow-up study of children fed formulas containing long-chain polyunsaturated fatty acids to 1 year of age. Pediatrics. 2003;112(3 Pt 1):e177-83.

129 Avoa, A.,Fischer, P. R. The influence of perinatal instruction about breast-feeding on neonatal weight loss. Pediatrics. 1990;86(2):313-5.

Country

130 Awasthi, S.,Misra, P. K.,Malik, G. K. Adequacy of breast milk. Indian Pediatr. 1987;24(10):873-7.

Country

131 Axelsson, I. E.,Ivarsson, S. A.,Raiha, N. C. Protein intake in early infancy: effects on plasma amino acid concentrations, insulin metabolism, and Group size growth. Pediatr Res. 1989;26(6):614-7.

132 Axelsson, I.,Borulf, S.,Righard, L.,Raiha, N. Protein and energy intake during weaning: I. Effects on growth. Acta Paediatr Scand. $1987 ; 76(2): 321-7$.

133 Ayatollahi, S. M.,Sharafi, Z.,Haem, E. Child Weight Growth Chart and Its Associated Factors in Birth Cohort of Maku Using a Growth Curve Model and LMS Method. Glob J Health Sci. 2015;7(6):44045

134 Aydemir, G.,Ozkurt, F. E. Otitis media with effusion in primary schools in Princes' Islands, Istanbul: Prevalence and risk factors. Journal of International Medical Research. 2011;39(3):866-872.

135 Ayer, J. G.,Belousova, E.,Harmer, J. A.,David, C.,Marks, G. B.,Celermajer, D. S. Maternal cigarette smoking is associated with reduced highdensity lipoprotein cholesterol in healthy 8-year-old children. Eur Heart J. 2011;32(19):2446-53.

136 Azizi, B. H.,Zulkifli, H. I.,Kasim, M. S. Protective and risk factors for acute respiratory infections in hospitalized urban Malaysian children: a case control study. Southeast Asian J Trop Med Public Health. 1995;26(2):280-5.

137 Babeely, K.,Kaste, L. M.,Husain, J.,Behbehani, J.,al-Za'abi, F.,Maher, T. C.,Tavares, M.,Soparkar, P.,DePaola, P. Severity of nursing-bottle syndrome and feeding patterns in Kuwait. Community Dent Oral Epidemiol. 1989;17(5):237-9.

\section{Group size}

Group size

Study design

Independent variable

Study design

Study design,

Independent variable

138 Backon, J. Prolonged breast feeding as a prophylaxis for recurrent otitis media: relevance of prostaglandins. Med Hypotheses. 1984;13(2):161. Study design 
142 Bagnoli, F., Casucci, M.,Toti, S.,Cecchi, S., Iurato, C.,Coriolani, G.,Tiezzi, M.,Vispi, L. Is vitamin D supplementation necessary in healthy full-term breastfed infants? A follow-up study of bone mineralization in healthy full-term infants with and without supplemental vitamin D. Minerva Pediatr 2013;65(3):253-60.

143 Baheiraei, A.,Ardsetani, N.,Ghazizadeh, Sh. Effects of progestogen-only contraceptives on breast-feeding and infant growth. International Journal of Gynecology and Obstetrics. 2001;74(2):203-205.

144 Bahl, R.,Frost, C.,Kirkwood, B. R.,Edmond, K.,Martines, J.,Bhandari, N.,Arthur, P. Infant feeding patterns and risks of death and hospitalization in the first half of infancy: multicentre cohort study. Bull World Health Organ. 2005;83(6):418-26.

Study design

Group size

Independent variable

Included for

systematic reviews not completed

145 Bai, K. I.,Sastry, V. N.,Reddy, C. C. A comparative study of feeding pattern of infants in rural and urban areas. Indian J Pediatr.

Country 1981;48(392):277-80.

146 Bailey W. Malnutrition among babies born to adolescent mothers. West Indian Med J. 1981;30:72-6.

Dependent variable, Health status

147 Bailey, P.,Tsui, A. O.,Janowitz, B.,Dominik, R.,Araujo, L. A study of infant mortality and causes of death in a rural north-east Brazilian community. J Biosoc Sci. 1990;22(3):349-63.

Included for systematic reviews not completed

148 Bailey, W. Clinical undernutrition in the Kingston/St Andrew metropolitan area: 1967-1976. Soc Sci Med D. 1981;15(4):471-7.

Study design, Dependent variable

149 Bainbridge, J. Breastfed babies less likely to become overweight children. British Journal of Midwifery. 2009;17(6):393-393 1p. Study design

150 Bainbridge, J. Higher IQs for breastfed babies. British Journal of Midwifery. 2008;16(6):394-394 1p.

Study design

151 Baird, J.,Poole, J.,Robinson, S., Marriott, L.,Godfrey, K.,Cooper, C.,Inskip, H.,Law, C. Milk feeding and dietary patterns predict weight and fat gains in infancy. Paediatr Perinat Epidemiol. 2008;22(6):575-86.

Included for systematic reviews not completed

152 Baker, D., Taylor, H.,Henderson, J. Inequality in infant morbidity: Causes and consequences in England in the 1990s. Journal of Epidemiology and Community Health. 1998;52(7):451-458. 
154 Baker, J. L.,Michaelsen, K. F.,Rasmussen, K. M.,Sorensen, T. I. Maternal prepregnant body mass index, duration of breastfeeding, and timing of complementary food introduction are associated with infant weight gain. Am J Clin Nutr. 2004;80(6):1579-88.

Included for systematic reviews not completed

Included for systematic reviews not completed environmental tobacco smoke in relation to lower respiratory illness in Czech children, from birth to 3 years of age. Environ Health Perspect. 2006;114(7):1126-32.

156 Balaban, G.,Motta, M. E.,Silva, G. A. Early weaning and other potential risk factors for overweight among preschool children. Clinics (Sao Paulo). 2010;65(2):181-7.

157 Ball, T. M.,Wright, A. L. Health care costs of formula-feeding in the first year of life. Pediatrics. 1999;103(4 Pt 2):870-6.

Included for systematic reviews not completed

158 Bammann, K.,Peplies, J.,De Henauw, S.,Hunsberger, M.,Molnar, D.,Moreno, L. A.,Tornaritis, M.,Veidebaum, T.,Ahrens, W.,Siani, A. Early life course risk factors for childhood obesity: the IDEFICS case-control study. PLoS One. 2014;9(2):e86914.

Included for systematic reviews not completed

Study design

159 Bandara, T.,Hettiarachchi, M.,Liyanage, C.,Amarasena, S. Current infant feeding practices and impact on growth in babies during the second half of infancy. J Hum Nutr Diet. 2015;28(4):366-74.

160 Bandoli, G.,von Ehrenstein, O. S.,Flores, M. E.,Ritz, B. Breastfeeding and Asthmatic Symptoms in The Offspring of Latinas: The Role of Maternal Nativity. J Immigr Minor Health. 2015;17(6):1739-45.

161 Bandurska-Stankiewicz, E.,Rutkowska, J. Environmental risk factors for type 1 diabetes in the north of Poland. Diabetologia Doswiadczalna i Kliniczna. 2008;8(2):81-84.

162 Banerji, A.,Greenberg, D.,White, L. F.,Macdonald, W. A.,Saxton, A., Thomas, E.,Sage, D.,Mamdani, M.,Lanctot, K. L.,Mahony, J. B.,Dingle, M.,Roberts, A. Risk factors and viruses associated with hospitalization due to lower respiratory tract infections in Canadian Inuit children : a case-control study. Pediatr Infect Dis J. 2009;28(8):697-701.

163 Bankel, M.,Robertson, A.,Kohler, B. Carious lesions and caries risk predictors in a group of Swedish children 2 to 3 years of age. One year observation. Eur J Paediatr Dent. 2011;12(4):215-9.

164 Baranowski, T.,Bryan, G. T.,Harrison, J. A.,Rassin, D. K.,Greaves, K. A.,Baranowski, J. H. Height, infant-feeding practices and cardiovascular functioning among 3 or 4 year old children in three ethnic groups. J Clin Epidemiol. 1992;45(5):513-8. Pediatr. 1990;11(5):234-9.

166 Barge, K. Breast-feeding doesn't contribute to dental caries. J Dent Hyg. 2007;81(4):69.
Study design

Study design

Included for

systematic reviews not completed

Study design

Study design

Study design

Study design 
169 Barros, F. C.,Rossello, J. L.,Matijasevich, A.,Dumith, S. C.,Barros, A. J.,dos Santos, I. S.,Mota, D., Victora, C. G. Gestational age at birth and Study design morbidity, mortality, and growth in the first 4 years of life: findings from three birth cohorts in Southern Brazil. BMC Pediatr. 2012;12:169.

170 Barros, F. C.,Semer, T. C.,Tonioli Filho, S.,Tomasi, E.,Victora, C. G. The impact of lactation centres on breastfeeding patterns, morbidity and growth: a birth cohort study. Acta Paediatr. 1995;84(11):1221-6.

Included for systematic reviews not completed

171 Barros, F. C.,Victora, C. G.,Morris, S. S.,Halpern, R.,Horta, B. L.,Tomasi, E. Breast feeding, pacifier use and infant development at 12 months of age: a birth cohort study in Brazil. Paediatr Perinat Epidemiol. 1997;11(4):441-50.

172 Barros, F. C.,Victora, C. G.,Vaughan, J. P.,Tomasi, E.,Horta, B. L.,Cesar, J. A.,Menezes, M. B.,Halpern, R.,Post, C. L.,del Mar Garcia, M. The epidemiological transition in maternal and child health in a Brazilian city, 1982-93: a comparison of two population-based cohorts. Paediatr Perinat Epidemiol. 2001;15(1):4-11.

173 Barroso, C. S.,Roncancio, A.,Hinojosa, M. B.,Reifsnider, E. The association between early childhood overweight and maternal factors. Child Obes. 2012;8(5):449-54

174 Barsam, F. J.,Borges, G. S.,Severino, A. B.,de Mello, L. M.,da Silva, A. S.,Nunes, A. A. Factors associated with community-acquired pneumonia in hospitalised children and adolescents aged 6 months to 13 years old. Eur J Pediatr. 2013;172(4):493-9.

Included for SRs not completed

Dependent variable

Study design

Included for systematic reviews not completed

Included for systematic reviews not completed

176 Bartok, C. J. Babies fed breastmilk by breast versus by bottle: a pilot study evaluating early growth patterns. Breastfeed Med. 2011;6(3):117-24.

Group size

177 Barton, S. J.,Howard, P. K.,Rayens, M. K. The effects of infant feeding decisions on infant growth. J Spec Pediatr Nurs. 2002;7(2):64-70.

Group size

178 Basheer, R. Breast is best. Nurs J India. 1988;79(7):180, 190.

179 Bassal, R.,Reisfeld, A.,Nissan, I.,Agmon, V.,Taran, D.,Schemberg, B.,Cohen, D.,Shohat, T. Risk factors for sporadic infection with Salmonella Infantis: a matched case-control study. Epidemiol Infect. 2014;142(4):820-5.

180 Batstra, L.,Neeleman, J.,Hadders-Algra, M. Can breast feeding modify the adverse effects of smoking during pregnancy on the child's cognitive development?. J Epidemiol Community Health. 2003;57(6):403-4.

181 Bauer, G.,Ewald, L. S.,Hoffman, J.,Dubanoski, R. Breastfeeding and cognitive development of three-year-old children. Psychol Rep. 1991;68(3 Study design Pt 2):1218
Study design

Dependent variable

Study design 
182 Baumgartner, C. Psychomotor and social development of breast-fed and bottle-fed babies during their first year of life. Acta Paediatr Hung. 1984;25(4):409-17

183 Baxter-Jones, A. D.,Cardy, A. H.,Helms, P. J.,Phillips, D. O.,Smith, W. C. Influence of socioeconomic conditions on growth in infancy: the 1921 Aberdeen birth cohort. Arch Dis Child. 1999;81(1):5-9.

Included for systematic reviews not completed

Group size level on synthesis and circulating cholesterol concentrations in human infants. Metabolism. 2002;51(1):25-33.

185 Bayley, T. M.,Alasmi, M.,Thorkelson, T.,Krug-Wispe, S.,Jones, P. J.,Bulani, J. L.,Tsang, R. C. Influence of formula versus breast milk on cholesterol synthesis rates in four-month-old infants. Pediatr Res. 1998;44(1):60-7.

186 Baylis, J. M.,Leeds, A. R.,Challacombe, D. N. Persistent nausea and food aversions in pregnancy. A possible association with cow's milk allergy Group size in infants. Clin Allergy. 1983;13(3):263-9.

187 Bayraktar, S.,Bayraktar, S. T.,Selcuk, N.,Emiroglu, H.,Elevli, M. Lipid and lipoprotein profile of breast fed, formula fed or mixed-fed 0-6-month-old babies. International Pediatrics. 2006;21(2):84-90.

188 Beath, K. J. Infant growth modelling using a shape invariant model with random effects. Stat Med. 2007;26(12):2547-64

Included for systematic reviews not completed

189 Beauchamp, J. N.,Gaboury, I.,Ni, A.,Boland, M. P.,Mac, K. D. R. Solid-food introduction in infants diagnosed as having a cow's-milk proteininduced enterocolitis. Journal of Pediatric Gastroenterology and Nutrition. 2011;52(5):639-643.

190 Beaudry, M.,Dufour, R.,Marcoux, S. Reaction between infant feeding and infections during the first six months of life. Journal of Pediatrics. 1995;126(2):191-197.

191 Beaudry, M.,Dufour, R.,Marcoux, S. Relation between infant feeding and infections during the first six months of life. J Pediatr. 1995;126(2):191- Study design 7.

192 Beaver, K. M.,Vaughn, M. G.,DeLisi, M.,Higgins, G. E. The biosocial correlates of neuropsychological deficits: results from the national longitudinal study of adolescent health. Int J Offender Ther Comp Criminol. 2010;54(6):878-94.

Independent variable Health status

Study design

Included for systematic reviews not completed

Study design Becher, J. C.,Bhushan, S. S.,Lyon, A. J. Unexpected collapse in apparently healthy newborns--a
of neonatal deaths and near-death events. Arch Dis Child Fetal Neonatal Ed. 2012;97(1):F30-4.

194 Beebe, D. W.,Rausch, J.,Byars, K. C.,Lanphear, B.,Yolton, K. Persistent snoring in preschool children: predictors and behavioral and developmental correlates. Pediatrics. 2012;130(3):382-9.

195 Beentjes VE,Weerheijm KL,Groen HJ. Factors involved in the aetiology of molar-incisor hypomineralisation (MIH). Eur J Paediatr Dent. 2002;3:9-13.
Independent variable Dependent variable

Study design 
Beilin, L.,Huang, R. C. Childhood obesity, hypertension, the metabolic syndrome and adult cardiovascular disease. Clin Exp Pharmacol Physiol. $\quad$ Study design 2008;35(4):409-11.

197 Belfort, M. B.,Rifas-Shiman, S. L.,Kleinman, K. P.,Guthrie, L. B.,Bellinger, D. C.,Taveras, E. M.,Gillman, M. W.,Oken, E. Infant feeding and childhood cognition at ages 3 and 7 years: Effects of breastfeeding duration and exclusivity. JAMA Pediatr. 2013;167(9):836-44.

Included for systematic reviews not completed

198 Belfort, M. B.,Rifas-Shiman, S. L.,Rich-Edwards, J. W.,Kleinman, K. P.,Oken, E.,Gillman, M. W. Infant growth and child cognition at 3 years of Independent variable age. Pediatrics. 2008;122(3):e689-95

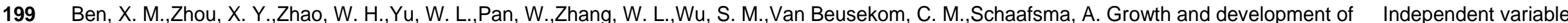
term infants fed with milk with long-chain polyunsaturated fatty acid supplementation. Chinese Medical Journal. 2004;117(8):1268-1270.

200 Bener, A.,Alsaied, A.,Al-Ali, M.,Al-Kubaisi, A.,Basha, B.,Abraham, A.,Guiter, G.,Mian, M. High prevalence of vitamin D deficiency in type 1 diabetes mellitus and healthy children. Acta Diabetol. 2009;46(3):183-9.

201 Bener, A.,Denic, S.,Galadari, S. Longer breast-feeding and protection against childhood leukaemia and lymphomas. Eur J Cancer 2001;37(2):234-8.

202 Benn, C. S.,Wohlfahrt, J.,Aaby, P.,Westergaard, T.,Benfeldt, E.,Michaelsen, K. F.,Bjorksten, B.,Melbye, M. Breastfeeding and risk of atopic dermatitis, by parental history of allergy, during the first 18 months of life. Am J Epidemiol. 2004;160(3):217-23.

203 Bennett, K. E.,Haggard, M. P. Accumulation of factors influencing children's middle ear disease: risk factor modelling on a large population cohort. J Epidemiol Community Health. 1998;52(12):786-93.

204 Berger, R.,Hadziselimovic, F.,Just, M.,Reigel, P. Effect of feeding human milk on nosocomial rotavirus infections in an infants ward. Dev Bio Stand. 1983;53:219-28.

Study design

Independent variable

Independent variable

Study design,

Dependent variable

Study design, Health status

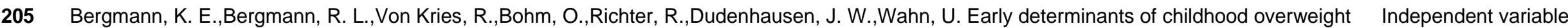
and adiposity in a birth cohort study: role of breast-feeding. Int J Obes Relat Metab Disord. 2003;27(2):162-72.

206 Bergmann, R. L.,Bergler, H.,Moshoudis, E.,Bergmann, K. E., Lachmann, E. Prevention of iron deficiency of breast-fed babies by using suitable additional food, a prospective, controlled study. Monatsschrift fur Kinderheilkunde. 1988;136:491.

Language, Study design

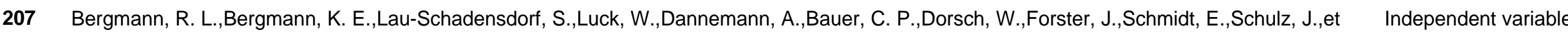
al.,. Atopic diseases in infancy. The German multicenter atopy study (MAS-90). Pediatr Allergy Immunol. 1994;5(6 Suppl):19-25.

208 Bergstrom, A.,Skov, T. H.,Bahl, M. I.,Roager, H. M.,Christensen, L. B.,Ejlerskov, K. T.,Molgaard, C.,Michaelsen, K. F.,Licht, T. R. Establishment of intestinal microbiota during early life: a longitudinal, explorative study of a large cohort of Danish infants. Appl Environ Microbiol. 2014;80(9):2889-900.

209 Bergstrom, E.,Hernell, O.,Persson, L. A.,Vessby, B. Serum lipid values in adolescents are related to family history, infant feeding, and physical growth. Atherosclerosis. 1995;117(1):1-13.

210 Beristain-Manterola, R.,Pasquetti-Ceccatelli, A.,Meléndez-Mier, G.,Sánchez-Escobar, O. A.,Cuevas-Covarrubias, S. A. Evaluation of iron status in healthy six-month-old infants in Mexican population: Evidence of a high prevalence of iron deficiency. e-SPEN. 2010;5(1):e37-e39. 
211 Berkowitz, C. D.,Uchiyama, N.,Tully, S. B.,Marble, R. D.,Spencer, M.,Stein, M. T.,Orr, D. P. Fever in infants less than two months of age: spectrum of disease and predictors of outcome. Pediatr Emerg Care. 1985;1(3):128-35.

212 Berkowitz, R. J. Streptococcus mutans and dental caries in infants. Compend Contin Educ Dent. 1985;6(6):463-6.

213 Bernard, A.,Nickmilder, M. Association of breastfeeding with higher serum inhibin B level at adolescence. JAMA Pediatr. 2013;167(9):869-70.

214 Bernard, J. Y.,Armand, M.,Garcia, C.,Forhan, A.,De Agostini, M.,Charles, M. A.,Heude, B. The association between linoleic acid levels in colostrum and child cognition at 2 and 3 y in the EDEN cohort. Pediatr Res. 2015;77(6):829-35.

215 Bernard, J. Y.,De Agostini, M.,Forhan, A.,Alfaiate, T.,Bonet, M.,Champion, V.,Kaminski, M.,de Lauzon-Guillain, B.,Charles, M. A.,Heude, B Breastfeeding duration and cognitive development at 2 and 3 years of age in the EDEN mother-child cohort. J Pediatr. 2013;163(1):36-42 e1.

216 Bernard, J. Y.,De Agostini, M.,Forhan, A.,de Lauzon-Guillain, B.,Charles, M. A.,Heude, B. The dietary n6:n3 fatty acid ratio during pregnancy is inversely associated with child neurodevelopment in the EDEN mother-child cohort. J Nutr. 2013;143(9):1481-8.

217 Bernardi, J. R.,Gama, C. M.,Vitolo, M. R. An infant feeding update program at healthcare centers and its impact on breastfeeding and morbidity. Cadernos de Saude Publica. 2011;27(6):1213-1222.

218 Berseth, C. L., Mitmesser, S. H.,Birch, E., Khoury, J.,Bean, J.,Harris, C.,Scalabrin, D. Intake of DHA/ARA via breast milk or formula supplementation during infancy can affect the incidence and recurrence of allergic manifestations in young children. Journal of Pediatric Gastroenterology and Nutrition. Conference: European Society for Paediatric Gastroenterology, Hepatology, and Nutrition Annual Meeting 2011 Sorrento Italy. Conference Start: 20110525 Conference End: 20110528. Conference Publication: (var.pagings). 2011;52(Suppl 2):E61.

219 Betoko, A.,Charles, M. A.,Hankard, R.,Forhan, A.,Bonet, M.,Regnault, N.,Botton, J.,Saurel-Cubizolles, M. J.,de Lauzon-Guillain, B. Determinants of infant formula use and relation with growth in the first 4 months. Matern Child Nutr. 2014;10(2):267-79.

220 Betran, A. P.,de Onis, M.,Lauer, J. A.,Villar, J. Ecological study of effect of breast feeding on infant mortality in Latin America. Bmj. 2001;323(7308):303-6

221 Beyerlein, A.,Fahrmeir, L.,Mansmann, U.,Toschke, A. M. Alternative regression models to assess increase in childhood BMI. BMC Med Res Methodol. 2008;8:59.

222 Bhan, M. K.,Arora, N. K.,Singh, K. D. Management of persistent diarrhea during infancy in clinical practice. Indian J Pediatr. 1991;58(6):769-74.

223 Bhatia, B. D.,Banerjee, D.,Agarwal, D. K.,Agarwal, K. N. Exterogestate growth: relationship with maternal body size and dietary intakes. Indian Pediatr. 1983;50(404):241-6

224 Bianchi, C.,Brambilla, P.,Cella, D.,Ragogna, F.,Tettamanti, C.,Del Puppo, M.,Kienle, M. G.,Chiumello, G.,Ruotolo, G. Influence of breast- and formula-feeding on plasma cholesterol precursor sterols throughout the first year of life. J Pediatr. 1997;131(6):928-31.
Study design, Country

Study design, Health status

Study design

Study design

Dependent variable

Included for systematic reviews not completed

Included for systematic reviews not completed

\section{Included for}

systematic reviews not

completed

Language

Peer review

Included for

systematic reviews not completed

Study design

Study design

Study design, Country

Group size 
226 Biesbroek, G.,Bosch, A. A.,Wang, X.,Keijser, B. J.,Veenhoven, R. H.,Sanders, E. A.,Bogaert, D. The impact of breastfeeding on nasopharyngeal microbial communities in infants. Am J Respir Crit Care Med. 2014;190(3):298-308.

Dependent variable

227 Biesbroek, G.,Tsivtsivadze, E.,Sanders, E. A.,Montijn, R.,Veenhoven, R. H.,Keijser, B. J.,Bogaert, D. Early respiratory microbiota composition determines bacterial succession patterns and respiratory health in children. Am J Respir Crit Care Med. 2014;190(11):1283-92.

Study design

Dependent variable

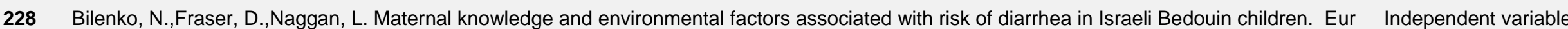
J Epidemiol. 1999;15(10):907-12.

229 Bindon, J. R. The influence of infant feeding patterns on growth of children in American Samoa. Med Anthropol. 1985;9(2):183-95

Independent variable

230 Binns C,James J,Lee MK. Trends in asthma, allergy and breastfeeding in Australia. Breastfeed Rev. 2013;21:7-8.

Study design

Study design

231 Bioavailability of milk zinc in infants. Nutr Rev. 1984;42:220-2.

232 Birch, E. E.,Garfield, S.,Castaneda, Y.,Hughbanks-Wheaton, D.,Uauy, R.,Hoffman, D. Visual acuity and cognitive outcomes at 4 years of age in a double-blind, randomized trial of long-chain polyunsaturated fatty acid-supplemented infant formula. Early Hum Dev. 2007;83(5):279-84.

Included for systematic reviews not completed

233 Birch, E. E.,Hoffman, D. R.,Uauy, R.,Birch, D. G.,Prestidge, C. Visual acuity and the essentiality of docosahexaenoic acid and arachidonic acid in the diet of term infants. Pediatr Res. 1998;44(2):201-9.

234 Birkbeck, J. A.,Buckfield, P. M.,Silva, P. A. Lack of long-term effect of the method of infant feeding on growth. Hum Nutr Clin Nutr. 1985;39(1):39-44.

235 Birkett, D. On bottle versus breast. Health Serv J. 2005;115(5957):19.

236 Bisgaard, H.,Halkjær, L. B.,Hinge, R.,Giwercman, C.,Palmer, C.,Silveira, L.,Strand, M. Risk analysis of early childhood eczema. Journal of Allergy and Clinical Immunology. 2009;123(6):1355-1360.e5.

237 Bishara, S. E.,Nowak, A. J.,Kohout, F. J.,Heckert, D. A.,Hogan, M. M. Influence of feeding and non-nutritive sucking methods on the development of the dental arches: longitudinal study of the first 18 months of life. Pediatr Dent. 1987;9(1):13-21.

238 Bishara, S. E.,Warren, J. J.,Broffitt, B.,Levy, S. M. Changes in the prevalence of nonnutritive sucking patterns in the first 8 years of life. Am J Orthod Dentofacial Orthop. 2006;130(1):31-6

239 Bishop, W. S. Weaning the breast-fed toddler or preschooler. Pediatr Nurs. 1985;11(3):211-4

240 Bjorke-Monsen, A. L. Is exclusive breastfeeding ensuring an optimal micronutrient status and psychomotor development in infants?. Clin Biochem. 2014;47(9):714.

241 Bjorksten, B.,Ait-Khaled, N.,Innes Asher, M.,Clayton, T. O.,Robertson, C. Global analysis of breast feeding and risk of symptoms of asthma, rhinoconjunctivitis and eczema in 6-7 year old children: ISAAC Phase Three. Allergol Immunopathol (Madr). 2011;39(6):318-25.
Study design

Study design

Group size

Independent variable

Independent variable

Independent variable

Independent variable

Study design

Study design 
242 Blake, P. A.,Ramos, S.,MacDonald, K. L.,Rassi, V.,Gomes, T. A.,Ivey, C.,Bean, N. H.,Trabulsi, L. R. Pathogen-specific risk factors and protective factors for acute diarrheal disease in urban Brazilian infants. J Infect Dis. 1993;167(3):627-32.

Blattner, C. M. Murase J. E. A practice gap in pediatric dermatology: does breast-feeding prevent the development of infantile atopic dermatitis? Study design J Am Acad Dermatol. 2014;71(2):405-6.

244 Bloom, K.,Goldbloom, R. B.,Robinson, S. C.,Stevens, F. E. Breast versus formula feeding. Acta Paediatr Scand Suppl. 1982;300:1-26.

Study design,

Dependent variable

245 Bocca, B.,Alimonti, A.,Giglio, L.,Di Pasquale, M.,Caroli, S.,Ambruzzi, M. A.,Bocca, A. P.,Coni, E. Nutritive significance of element speciation in breast milk. The case of calcium, copper, iron, magnesium, manganese, and zinc. Adv Exp Med Biol. 2000;478:385-6.

Study design,

Dependent variable

246 Boccolini, C. S.,Carvalho, M. L.,Oliveira, M. I.,Boccolini Pde, M. Breastfeeding can prevent hospitalization for pneumonia among children under 1 year old. J Pediatr (Rio J). 2011;87(5):399-404.

247 Boccolini, C. S.,Carvalho, M. L.,Oliveira, M. I.,Perez-Escamilla, R. Breastfeeding during the first hour of life and neonatal mortality. J Pediatr (Rio J). 2013;89(2):131-6.

248 Bodington, M. J.,McNally, P. G.,Burden, A. C. Cow's milk and type 1 childhood diabetes: no increase in risk. Diabet Med. 1994;11(7):663-5.

Study design, Independent variable

Study design

249 Boediman, D.,Murakami, R.,Nakamura, H.,Matsuo, T. Plasma apolipoprotein and lipid profiles in infants in the first year of life. Kobe J Med Sci. Group size 1989;35(3):165-76

250 Boerma, J. T.,Bicego, G. T. Preceding birth intervals and child survival: searching for pathways of influence. Stud Fam Plann. 1992;23(4):24356.

Study design, Independent variable

251 Bogen, D. L.,Hanusa, B. H.,Whitaker, R. C. The effect of breast-feeding with and without formula use on the risk of obesity at 4 years of age. Obes Res. 2004;12(9):1527-35.

Included for systematic reviews not completed

252 Bognetti, E.,Meschi, F.,Malavasi, C.,Pastore, M. R.,Sergi, A.,Illeni, M. T.,Maffeis, C.,Pinelli, L.,Chiumello, G. HLA-antigens in Italian type 1

Dependent variable diabetic patients: role of DR3/DR4 antigens and breast feeding in the onset of the disease. Acta Diabetol. 1992;28(3-4):229-32.

253 Bolanos, A. V.,Caire, G.,Valencia, M. E.,Casanueva, E.,Roman Perez, R.,Calderon de la Barca, A. M. Energy intake and growth of breast-fed infants in two regions of Mexico. Adv Exp Med Biol. 2000;478:371-2.

254 Bond, S. Randomized trial provides strong evidence that prolonged, exclusive breastfeeding enhances cognitive development in children. Journal of Midwifery \& Women's Health. 2008;53(5):472-473 2p.

255 Bonuck, K. A.,Freeman, K.,Trombley, M. Randomized controlled trial of a prenatal and postnatal lactation consultant intervention on infant health care use. Arch Pediatr Adolesc Med. 2006;160(9):953-60.

Study design

Study design

Included for systematic reviews not completed

256 Bonuck, K.,Avraham, S. B.,Lo, Y.,Kahn, R.,Hyden, C. Bottle-weaning intervention and toddler overweight. J Pediatr. $2014 ; 164(2): 306-12$ e1-2. 
Borgnolo, G.,Barbone, F.,Scornavacca, G.,Fra children. Acta Paediatr. 1996;85(7):804-8.

260 Bornhorst, C.,Siani, A.,Russo, P.,Kourides, Y.,Sion, I.,Molnar, D.,Moreno, L. A.,Rodriguez, G.,Ben-Shlomo, Y.,Howe, L.,Lissner, L.,Mehlig, K.,Regber, S.,Bammann, K.,Foraita, R.,Ahrens, W.,Tilling, K. Early Life Factors and Inter-Country Heterogeneity in BMI Growth Trajectories of European Children: The IDEFICS Study. PLoS One. 2016;11(2):e0149268.

Study design

Health status

Included for systematic reviews not completed

261 Bortolini, G. A.,Vitolo, M. R. The impact of systematic dietary counseling during the first year of life on prevalence rates of anemia and iron deficiency at 12-16 months. J Pediatr (Rio J). 2012;88(1):33-9.

Included for systematic reviews not completed

262 Boshuizen, H. C., Verkerk, P. H.,Reerink, J. D.,Herngreen, W. P.,Zaadstra, B. M., Verloove-Vanhorick, S. P. Maternal smoking during lactation: Independent variable relation to growth during the first year of life in a Dutch birth cohort. Am J Epidemiol. 1998;147(2):117-26.

263 Boskabadi, H.,Ramazanzadeh, M.,Zakerihamidi, M.,Omran, F. R. Risk factors of breast problems in mothers and its effects on newborns. Iranian Red Crescent Medical Journal. 2014;16(6).

264 Boulton, J. Nutrition in childhood and its relationships to early somatic growth, body fat, blood pressure, and physical fitness. Acta Paediatr Scand Suppl. 1981;284:1-85.

265 Boutwell, B. B.,Beaver, K. M.,Barnes, J. C. Role of breastfeeding in childhood cognitive development: a propensity score matching analysis. J Paediatr Child Health. 2012;48(9):840-5.

Independent variable Dependent variable

Study design

Included for systematic reviews not completed

266 Bouwstra, H.,Boersma, E. R.,Boehm, G.,Dijck-Brouwer, D. A.,Muskiet, F. A.,Hadders-Algra, M. Exclusive breastfeeding of healthy term infants for at least 6 weeks improves neurological condition. J Nutr. 2003;133(12):4243-5.

Included for systematic reviews not completed

267 Bouwstra, H.,Dijck-Brouwer, D. A.,Boehm, G.,Boersma, E. R.,Muskiet, F. A.,Hadders-Algra, M. Long-chain polyunsaturated fatty acids and neurological developmental outcome at 18 months in healthy term infants. Acta Paediatr. 2005;94(1):26-32.

Included for systematic reviews not completed

268 Bouwstra, H.,Dijck-Brouwer, D. A.,Wildeman, J. A.,Tjoonk, H. M.,van der Heide, J. C.,Boersma, E. R.,Muskiet, F. A.,Hadders-Algra, M. LongIndependent variable chain polyunsaturated fatty acids have a positive effect on the quality of general movements of healthy term infants. Am $\mathrm{J}$ Clin Nutr. 2003;78(2):313-8.

269 Bouwstra, H.,Dijck-Brouwer, J.,Decsi, T.,Boehm, G.,Boersma, E. R.,Muskiet, F. A.,Hadders-Algra, M. Neurologic condition of healthy term infants at 18 months: positive association with venous umbilical DHA status and negative association with umbilical trans-fatty acids. Pediat Independent variable Res. 2006;60(3):334-9. 
270 Bove, I.,Campoy, C.,Uauy, R.,Miranda, T.,Cerruti, F. Trends in early growth indices in the first 24 months of life in Uruguay over the past decade. Study design J Health Popul Nutr. 2014;32(4):600-7.

271 Bradley, C. K.,Hillman, L.,Sherman, A. R.,Leedy, D.,Cordano, A. Evaluation of two iron-fortified, milk-based formulas during infancy. Pediatrics. 1993;91(5):908-14

Included for systematic reviews not completed

272 Braga GC, Ferriolli E, Quintana SM, Ferriani RA, Pfrimer K, Vieira CS. Immediate Post-Partum Initiation of Etonogestrel-Releasing Implant: A Randomized Controlled Trial on Breastfeeding Impact. Obstet Gynecol Survey. 2015;70:702-4.

273 Bramhagen, A. C.,Svahn, J.,Hallstrom, I.,Axelsson, I. Factors influencing iron nutrition among one-year-old healthy children in Sweden. J Clin Nurs. 2011;20(13-14):1887-94.

274 Brams, M.,Maloney, J. "Nursing bottle caries" in breast-fed children. J Pediatr. 1983;103(3):415-6.

Study design

Study design

Study design

275 Brandenburg, A. H.,Jeannet, P. Y.,Steensel-Moll, H. A.,Ott, A.,Rothbarth, P. H.,Wunderli, W.,,Suter, S.,Neijens, H. J.,Osterhaus, A. D.,Siegrist, C. A. Local variability in respiratory syncytial virus disease severity. Arch Dis Child. 1997;77(5):410-4.

276 Brandstrom, A.,Brostrom, G.,Persson, L. A. The impact of feeding patterns on infant mortality in a nineteenth century Swedish parish. J Trop Pediatr. 1984;30(3):154-9.

277 Bray, K. K.,Branson, B. G.,Williams, K. Early childhood caries in an urban health department: an exploratory study. J Dent Hyg. 2003;77(4):225- Study design 32.

278 Breast feeding and child development at five years. Nutr Rev. 1985;43:173-4.

Study design

279 Breast feeding seems to reduce the risk of obesity in children. Bmj. 1999;319(7203):B.

Study design

280 Breast feeding: benefits and hazards. Early Hum Dev. 1997;49 Suppl:S1-203.

Study design

281 Breast versus bottle: an in-house debate. Midwife Health Visit Community Nurse. 1988;24(7):254-5

Study design

282 Breast-feeding and human milk. Eur J Obstet Gynecol Reprod Biol. 1983;15(4-6):385-94.

Study design

283 Breastfeeding could be linked to higher IQ. Perspect Public Health. 2015;135(3):114.

Study design

284 Breastfeeding for the health of baby and mother. Nurs J India. 2011;102(8):179.

Study design

285 Breastfeeding study looks at behaviour. Midwives. 2012;15(1):9-9 1p

Study design

286 Breastfeeding. Nurs Womens Health. 2015;19(1):83-8.

Study design

287 Breastfeeding: sensitive mothers and intelligent offspring. Arch Dis Child. 2015;100(6):601.

Study design

288 Brew, B. K.,Kull, I.,Garden, F.,Almqvist, C.,Bergstrom, A.,Lind, T.,Webb, K.,Wickman, M.,Marks, G. B. Breastfeeding, asthma, and allergy: a tale Study design of two cities. Pediatr Allergy Immunol. 2012;23(1):75-82. 
291 Brion, M. J. A.,Lawlor, D. A.,Matijasevich, A.,Horta, B.,Anselmi, L.,Araújo, C. L.,Menezes, A. M. B.,Victora, C. G.,Smith, G. D. What are the causal effects of breastfeeding on IQ, obesity and blood pressure? Evidence from comparing high-income with middle-income cohorts. International Journal of Epidemiology. 2011;40(3):670-680.

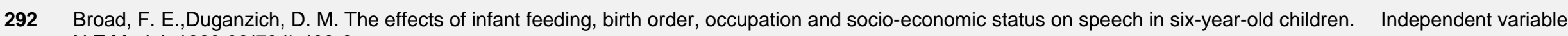
N Z Med J. 1983;96(734):483-6.

293 Brodish, M. S. Relationship of early bonding to initial infant feeding patterns in bottle-fed newborns. JOGN Nurs. 1982;11(4):248-52. Independent variable

294 Brooks, J. G.,Gilbert, R. E.,Flemming, P. J.,Berry, P. J.,Golding, J. Postnatal growth preceding sudden infant death syndrome. Pediatrics. 1994;94(4 Pt 1):456-61.

Included for systematic reviews not completed

295 Broor, S.,Pandey, R. M.,Ghosh, M.,Maitreyi, R. S.,Lodha, R.,Singhal, T.,Kabra, S. K. Risk factors for severe acute lower respiratory tract infection in under-five children. Indian Pediatr. 2001;38(12):1361-9.

296 Brown, A.,Lee, M. Breastfeeding during the first year promotes satiety responsiveness in children aged 18-24 months. Pediatr Obes. 2012;7(5):382-90.

Country

Included for systematic reviews not completed

297 Brown, J. P.,Junner, C.,Liew, V. A study of Streptococcus mutans levels in both infants with bottle caries and their mothers. Aust Dent J. 1985;30(2):96-8.

298 Brown, K. H.,Black, R. E.,Lopez de Romana, G.,Creed de Kanashiro, H. Infant-feeding practices and their relationship with diarrheal and other Independent variable diseases in Huascar (Lima), Peru. Pediatrics. 1989;83(1):31-40.

299 Brown, K. H.,Stallings, R. Y.,de Kanashiro, H. C., Lopez de Romana, G.,Black, R. E. Effects of common illnesses on infants' energy intakes from breast milk and other foods during longitudinal community-based studies in Huascar (Lima), Peru. Am J Clin Nutr. 1990;52(6):1005-13.

300 Broxton, D. Infant feeding research summaries. International Journal of Childbirth Education. 2008;23(2):28-31 4p. 301 Bruce, L., Lieberman, L. S. Nutritional anthropometry and dietary intake of children from the Las Cuevas region of the Dominican Republic. Arch Study design
Latinoam Nutr. 1987;37(2):250-8.

302 Bruerd, B.,Kinney, M. B.,Bothwell, E. Preventing baby bottle tooth decay in American Indian and Alaska native communities: a model for Independent variable planning. Public Health Rep. 1989;104(6):631-40.

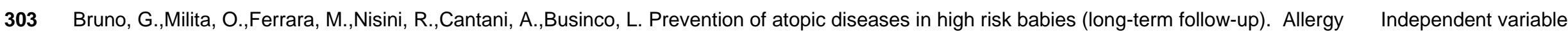
Proc. 1993;14(3):181-6; discussion 186-7. 
304 Brunser, O.,Espinoza, J.,Figueroa, G.,Araya, M.,Spencer, E.,Hilpert, H.,Link-Amster, H.,Brussow, H. Field trial of an infant formula containing anti-rotavirus and anti-Escherichia coli milk antibodies from hyperimmunized cows. J Pediatr Gastroenterol Nutr. 1992;15(1):63-72.

305 Buckley, K. M. Long-term breastfeeding: nourishment or nurturance?. J Hum Lact. 2001;17(4):304-12.

Study design

Independent variable

306 Buinauskiene, J.,Baliutaviciene, D.,Zalinkevicius, R. Glucose tolerance of 2- to 5-yr-old offspring of diabetic mothers. Pediatric Diabetes. 2004;5(3):143-146.

307 Bulk-Bunschoten, A. M.,Pasker-de Jong, P. C.,van Wouwe, J. P.,de Groot, C. J. Ethnic variation in infant-feeding practices in the Netherlands and weight gain at 4 months. J Hum Lact. 2008;24(1):42-9.

308 Bulk-Bunschoten, A. M.,van Bodegom, S.,Reerink, J. D.,de Jong, P. C.,de Groot, C. J. Weight and weight gain at 4 months (The Netherlands 1998): influences of nutritional practices, socio-economic and ethnic factors. Paediatr Perinat Epidemiol. 2002;16(4):361-9.

309 Bulkow, L. R.,Singleton, R. J.,DeByle, C.,Miernyk, K.,Redding, G.,Hummel, K. B.,Chikoyak, L.,Hennessy, T. W. Risk factors for hospitalization with lower respiratory tract infections in children in rural Alaska. Pediatrics. 2012;129(5):e1220-7.

Independent variable

Independent variable Dependent variable

Independent variable

Included for systematic reviews not completed

Included for systematic reviews not completed children. Pediatrics. 2002;109(2):210-6.

311 Bunik, M.,Shobe, P.,O'Connor, M. E.,Beaty, B.,Langendoerfer, S.,Crane, L. Randomized controlled trial to evaluate a telephone support intervention for breastfeeding in low-income Latina mothers. Breastfeeding medicine. 2007;2(3):183.

Study design

312 Burdette, H. L.,Whitaker, R. C. Differences by race and ethnicity in the relationship between breastfeeding and obesity in preschool children Ethn Dis. 2007;17(3):467-70.

Included for systematic reviews not completed

313 Burdette, H. L.,Whitaker, R. C.,Hall, W. C.,Daniels, S. R. Breastfeeding, introduction of complementary foods, and adiposity at 5 y of age. Am J Clin Nutr. 2006;83(3):550-8.

Included for systematic reviews not completed

314 Burke, V.,Beilin, L. J.,Simmer, K.,Oddy, W. H.,Blake, K. V.,Doherty, D.,Kendall, G. E.,Newnham, J. P.,Landau, L. I.,Stanley, F. J. Breastfeeding and overweight: Iongitudinal analysis in an Australian birth cohort. J Pediatr. 2005;147(1):56-61.

\section{Included for}

systematic reviews not completed

315 Burns, E.,Schmied, V.,Sheehan, A.,Fenwick, J. Let women express themselves - breastfeeding study. Australian Nursing Journal. Study design 2009;17(2):44-45 2p.

316 Businco, L.,Marchetti, F.,Pellegrini, G.,Cantani, A.,Perlini, R. Prevention of atopic disease in "at-risk newborns" by prolonged breast-feeding.

Independent variable Ann Allergy. 1983;51(2 Pt 2):296-9.

317 Butland, B. K.,Strachan, D. P.,Lewis, S.,Bynner, J.,Butler, N.,Britton, J. Investigation into the increase in hay fever and eczema at age 16 observed between the 1958 and 1970 British birth cohorts. BMJ. 1997;315(7110):717-21. 
320 Butte, N. F.,Wong, W. W.,Ferlic, L.,Smith, E. O.,Klein, P. D.,Garza, C. Energy expenditure and deposition of breast-fed and formula-fed infants during early infancy. Pediatr Res. 1990;28(6):631-40.

321 Butte, N. F.,Wong, W. W.,Hopkinson, J. M.,Smith, E. O.,Ellis, K. J. Infant feeding mode affects early growth and body composition. Pediatrics. 2000;106(6):1355-66.

Study design

Included for

systematic reviews not completed

322 Butters, L.,McCabe, R. The influence of breast and bottle feeding on blood pressure. Midwifery. 1988;4(3):130-2.

Study design

Dependent variable

323 Buyken, A. E.,Karaolis-Danckert, N.,Remer, T.,Bolzenius, K.,Landsberg, B.,Kroke, A. Effects of breastfeeding on trajectories of body fat and BMI throughout childhood. Obesity (Silver Spring). 2008;16(2):389-95.

Included for systematic reviews not completed

324 Bystrova, K.,Matthiesen, A. S.,Widstrom, A. M.,Ransjo-Arvidson, A. B.,Welles-Nystrom, B.,Vorontsov, I.,Uvnas-Moberg, K. The effect of Russian Maternity Home routines on breastfeeding and neonatal weight loss with special reference to swaddling. Early Hum Dev. 2007;83(1):29-39.

Study design Independent variable

325 Cable, N.,Bartley, M.,McMunn, A.,Kelly, Y. 011 Gender differences in the effect of breast feeding on adult psychological well-being. Journal of No full text Epidemiology \& Community Health. 2010;64:A4-5 1p.

326 Cable, N.,Bartley, M.,McMunn, A.,Kelly, Y. Gender differences in the effect of breastfeeding on adult psychological well-being. Eur J Public Health. 2012;22(5):653-8.

\section{Included for}

systematic reviews not completed

327 Cai, S.,Pang, W. W.,Low, Y. L.,Sim, L. W.,Sam, S. C.,Bruntraeger, M. B.,Wong, E. Q.,Fok, D.,Broekman, B. F.,Singh, L.,Richmond, J.,Agarwal, P.,Qiu, A.,Saw, S. M.,Yap, F.,Godfrey, K. M.,Gluckman, P. D.,Chong, Y. S., Meaney, M. J.,Kramer, M. S.,Rifkin-Graboi, A. Infant feeding effects on early neurocognitive development in Asian children. Am J Clin Nutr. 2015;101(2):326-36.

328 Calamaro, C. J. Infant nutrition in the first year of life: tradition or science?. Pediatr Nurs. 2000;26(2):211-5. completed

330 Cama, R. I.,Parashar, U. D.,Taylor, D. N.,Hickey, T.,Figueroa, D.,Ortega, Y. R.,Romero, S.,Perez, J.,Sterling, C. R.,Gentsch, J. R.,Gilman, R. H.,Glass, R. I. Enteropathogens and other factors associated with severe disease in children with acute watery diarrhea in Lima, Peru. Journal of Infectious Diseases. 1999;179(5):1139-1144.

331 Camara, A. A.,Silva, J. M.,Ferriani, V. P.,Tobias, K. R.,Macedo, I. S.,Padovani, M. A.,Harsi, C. M.,Cardoso, M. R.,Chapman, M. D.,Arruda, E.,Platts-Mills, T. A.,Arruda, L. K. Risk factors for wheezing in a subtropical environment: role of respiratory viruses and allergen sensitization. J Allergy Clin Immunol. 2004;113(3):551-7. 
333 Cameron M,Hofvander Y. Problems associated with breast-milk substitutes. Nurs J India. 1984;75:245-6, 247, 249-50.

334 Cameron, S. L.,Gray, A. R., Taylor, R. W.,Lawrence, J. A.,Galland, B. C.,Hanna, M. B.,Heath, A. L. M.,Sayers, R. M.,Taylor, B. J. Excessive

No full text

growth from 6 to 24 months of age: Results from the prevention of overweight in infancy (POI) randomised controlled trial. Archives of disease in childhood. 2014;99:A109.

335 Campbell N. The nutritional and immunological benefits of breast milk. Aust Nurses J. 1981;10:40-3, 47.

Study design

336 Campus, G.,Solinas, G.,Sanna, A.,Maida, C.,Castiglia, P. Determinants of ECC in Sardinian preschool children. Community Dent Health. 2007;24(4):253-6.

337 Camurdan, M. O.,Camurdan, A. D.,Polat, S.,Beyazova, U. Growth patterns of large, small, and appropriate for gestational age infants: impacts long-term breastfeeding: a retrospective cohort study. J Pediatr Endocrinol Metab. 2011;24(7-8):463-8.

338 Cant, A. J.,Bailes, J. A. How should we feed the potentially allergic infant?. Hum Nutr Appl Nutr. 1984;38(6):474-6.

Independent variable

Independent variable

Cantani, A.,Micera, M. Neonatal cow milk sensitization in 143 case-reports: role of early exposure to cow's milk formula. Eur Rev Med Pharmacol Sci. 2005;9(4):227-30.

340 Cantey, J. B.,Bascik, S. L.,Heyne, N. G.,Gonzalez, J. R.,Jackson, G. L.,Rogers, V. L.,Sheffield, J. S., Trevino, S.,Sendelbach, D.,Wendel, G. D.,Sanchez, P. J. Prevention of mother-to-infant transmission of influenza during the postpartum period. Am J Perinatol. 2013;30(3):233-40.

$$
\text { Capeding, R.,Gepanayao, C. P.,Calimon, N.,Lebumfacil, J.,Davis, A. M.,Stouffer, N.,Harris, B. J. Lutein-fortified infant formula fed to healthy term }
$$
infants: evaluation of growth effects and safety. Nutr J. 2010;9:22.

342 Caplan, L. S.,Erwin, K.,Lense, E.,Hicks, J., Jr. The potential role of breast-feeding and other factors in helping to reduce early childhood caries. J Public Health Dent. 2008;68(4):238-41.

Study design, Independent variable

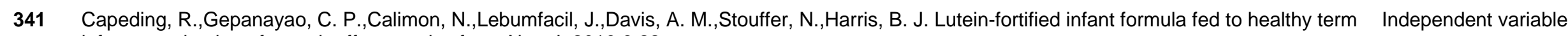

343 Capozzi, L.,Russo, R.,Bertocco, F.,Ferrara, D.,Ferrara, M. Diet and iron deficiency in the first year of life: a retrospective study. Hematology. 2010;15(6):410-3.

Study design, Independent variable

Included for systematic reviews not completed

344 Capozzi, L.,Russo, R.,Bertocco, F.,Ferrara, D.,Ferrara, M. Effect on haematological and anthropometric parameters of iron supplementation in the first 2 years of life. Risks and benefits. Hematology. 2011;16(5):261-4.

345 Carberry, A. E.,Colditz, P. B.,Lingwood, B. E. Body composition from birth to 4.5 months in infants born to non-obese women. Pediatr Res 2010;68(1):84-8.

346 Carling, S. J.,Demment, M. M.,Kjolhede, C. L.,Olson, C. M. Breastfeeding duration and weight gain trajectory in infancy. Pediatrics. 2015;135(1):111-9.

Independent variable

Group size

Included for

systematic reviews not completed 
348 Carlson, S. E.,DeVoe, P. W.,Barness, L. A. Effect of infant diets with different polyunsaturated to saturated fat ratios on circulating high-density

Group size lipoproteins. J Pediatr Gastroenterol Nutr. 1982;1(3):303-9.

349 Carpenter, R.,McGarvey, C.,Mitchell, E. A.,Tappin, D. M.,Vennemann, M. M.,Smuk, M.,Carpenter, J. R. Bed sharing when parents do not smoke: Is there a risk of SIDS? An individual level analysis of five major case-control studies. BMJ Open. 2013;3(5).

Included for

systematic reviews not completed

350 Carr, A. Breastfeeding and the WIC program. Breastfeed Med. 2009;4 Suppl 1:S57-8.

Study design

351 Carrascoza, K. C.,Possobon Rde, F.,Tomita, L. M.,Moraes, A. B. Consequences of bottle-feeding to the oral facial development of initially breastfed children. J Pediatr (Rio J). 2006;82(5):395-7.

352 Carroll, T. P. Substantially increasing breastfeeding: an accomplishment of the Alabama WIC Program. J Hum Lact. 1994;10(2):129-30.

353 Carson, C. G. Risk factors for developing atopic dermatitis. Dan Med J. 2013;60(7):B4687.

Language

Study design Dependent variable Independent variable

354 Carter, C. S.,Porges, E. C. Parenthood, stress, and the brain. Biol Psychiatry. 2011;70(9):804-5. Study design

355 Carvalho, R.,Johnson, E.,Kozlosky, M.,Scheimann, A. O. Clinical profile of the overweight child in the new millennium. Clin Pediatr (Phila). 2008;47(5):476-82.

Study design, Health status

356 Casazza, Krista,Fernandez, Jose R.,Allison, David B. Modest Protective Effects of Breast-feeding on Obesity: Is the Evidence Truly Supportive?. Study design Nutrition Today. 2012;47(1):33-40 8p.

357 Casiday, R. E.,Wright, C. M.,Panter-Brick, C.,Parkinson, K. N. Do early infant feeding patterns relate to breast-feeding continuation and weight gain? Data from a longitudinal cohort study. Eur J Clin Nutr. 2004;58(9):1290-6.

Included for

systematic reviews not completed

Included for systematic reviews not completed

Study design

359 Cassimos, D. C.,Tsalkidis, A.,Tripsianis, G. A.,Stogiannidou, A.,Anthracopoulos, M.,Ktenidou-Kartali, S.,Aivazis, V.,Gardikis, S.,Chatzimichael, A. Asthma, lung function and sensitization in school children with a history of bronchiolitis. Pediatr Int. 2008;50(1):51-6.

360 Castelo, P. M.,Gaviao, M. B.,Pereira, L. J.,Bonjardim, L. R. Maximal bite force, facial morphology and sucking habits in young children with functional posterior crossbite. J Appl Oral Sci. 2010;18(2):143-8.

361 Castillo, C.,Atalah, E.,Riumallo, J.,Castro, R. Breast-feeding and the nutritional status of nursing children in Chile. Bull Pan Am Health Organ. 1996;30(2):125-33.
Study design

Study design 
363 Castro-Rodriguez, J. A.,Stern, D. A.,Halonen, M.,Wright, A. L.,Holberg, C. J.,Taussig, L. M.,Martinez, F. D. Relation between infantile colic and

Dependent variable asthma/atopy: a prospective study in an unselected population. Pediatrics. 2001;108(4):878-82

364 Catch-up growth following severe malnutrition. Nutr Rev. 1986;44(5):173-5.

Study design

365 Cattaneo, A. Infant and young child feeding: solid facts. Breastfeed Rev. 2013;21(2):7-9.

Study design

366 Cattaneo, A.,Ronfani, L.,Burmaz, T.,Quintero-Romero, S.,Macaluso, A.,Di Mario, S. Infant feeding and cost of health care: a cohort study. Acta Paediatr. 2006;95(5):540-6.

367 Cattaneo, A.,Timmer, A.,Bomestar, T.,Bua, J.,Kumar, S.,Tamburlini, G. Child nutrition in countries of the Commonwealth of Independent States: time to redirect strategies?. Public Health Nutr. 2008;11(12):1209-19.

368 Caudri, D.,Savenije, O. E.,Smit, H. A.,Postma, D. S.,Koppelman, G. H.,Wijga, A. H.,Kerkhof, M.,Gehring, U.,Hoekstra, M. O.,Brunekreef, B.,de Jongste, J. C. Perinatal risk factors for wheezing phenotypes in the first 8 years of life. Clin Exp Allergy. 2013;43(12):1395-405.

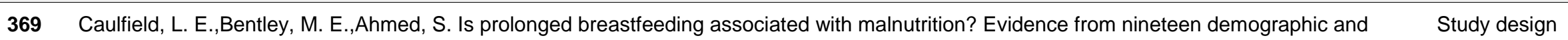
health surveys. Int J Epidemiol. 1996;25(4):693-703.

370 Caulfield, L. E.,Bose, A.,Chandyo, R. K.,Nesamvuni, C.,de Moraes, M. L.,Turab, A.,Patil, C.,Mahfuz, M.,Ambikapathi, R.,Ahmed, T. Infant feeding practices, dietary adequacy, and micronutrient status measures in the MAL-ED study. Clin Infect Dis. 2014;59 Suppl 4:S248-54.

Study design

Cavalcante e Silva, A.,Correia, L. L.,Campos, J. S.,Andrade, F. M.,Silveira, D. M.,Leite, A. J.,Rocha, H. A.,Machado, M. M.,Cunha, A. J. Reducing child mortality: the contribution of Ceara state, northeast of Brazil, on achieving the Millennium Development Goal 4 in Brazil. Matern Child Health J. 2015;19(4):700-6.

372 Çelikkiran, S.,Bozkurt, H.,Coşkun, M. Denver developmental test findings and their relationship with sociodemographic variables in a large community sample of 0-4-year-old children. Noropsikiyatri Arsivi. 2015;52(2):180-184.

373 Celikkiran, S.,Bozkurt, H.,Coskun, M. Denver developmental test findings and their relationship with sociodemographic variables in a large community sample of 0-4-year-old children. Noropsikiyatri Arsivi. 2015;52(2):180-4.

374 Centers for Disease Control (CDC). Progress toward the 1990 objectives for improved nutrition. MMWR Morb Mortal Wkly Rep. 1988;37:475-9.

375 Cerrato, P. L. Does milk cause juvenile diabetes?. Rn. 1993;56(1):69-72

Study design

Dependent variable

Study design

376 Cerrato, P. L. Preventing food allergies. Rn. 1992;55(10):73-5.

Study design

Study design

Study design

Study design

Study design

377 Cesar, J. A., Victora, C. G.,Barros, F. C.,Santos, I. S.,Flores, J. A. Impact of breast feeding on admission for pneumonia during postneonatal period in Brazil: nested case-control study. BMJ. 1999;318(7194):1316-20. 
379 Chaimay, B.,Ruagdaraganon, N.,Thinkhamrop, B.,Thinkhamrop, J. Association between infant feeding practices and first meaningful words at

Included for

first year of life: a prospective cohort study of Thai children. Asia Pac J Public Health. 2015;27(2):NP1071-84.

systematic reviews not completed

380 Challacombe, D. N.,Mecrow, I. K.,Elliott, K.,Clarke, F. J.,Wheeler, E. E. Changing infant feeding practices and declining incidence of coeliac

Dependent variable disease in West Somerset. Arch Dis Child. 1997;77(3):206-9.

381 Chaman, R.,Alami, A.,Emamian, M. H.,Naieni, K. H.,Mirmohammadkhani, M.,Ahmadnezhad, E.,Entezarmahdi, R.,Shati, M.,Shariati, M. Important risk factors of mortality among children aged 1-59 months in rural areas of Shahroud, Iran: A community-based nested case-control study. International Journal of Preventive Medicine. 2012;3(12):875-879.

382 Chan, G. M.,Leeper, L.,Book, L. S. Effects of soy formulas on mineral metabolism in term infants. Am J Dis Child. 1987;141(5):527-30.

Included for systematic reviews not completed

Group size

Group size maternal bone mineral status. Am J Clin Nutr. 1982;36(3):438-43.

384 Chandra, R. K. Five-year follow-up of high-risk infants with family history of allergy who were exclusively breast-fed or fed partial whey hydrolysate, soy, and conventional cow's milk formulas. J Pediatr Gastroenterol Nutr. 1997;24(4):380-8.

385 Chandra, R. K.,Hamed, A. Cumulative incidence of atopic disorders in high risk infants fed whey hydrolysate, soy, and conventional cow milk formulas. Ann Allergy. 1991;67(2 Pt 1):129-32.

386 Chandra, R. K.,Puri, S.,Cheema, P. S. Predictive value of cord blood IgE in the development of atopic disease and role of breast-feeding in its prevention. Clin Allergy. 1985;15(6):517-22.

387 Chandra, R. K.,Puri, S.,Hamed, A. Influence of maternal diet during lactation and use of formula feeds on development of atopic eczema in high Retracted risk infants BMJ 1989 Oct 7;299(6704):896. BMJ (Clinical research ed.). 1989;299(6693):228-30.

388 Chandra, R. K.,Puri, S.,Suraiya, C.,Cheema, P. S. Influence of maternal food antigen avoidance during pregnancy and lactation on incidence of Reliability atopic eczema in infants. Clin Allergy. 1986;16(6):563-9.

389 Chandran, L.,Gelfer, P. Breastfeeding: the essential principles. Pediatr Rev. 2006;27(11):409-17.

390 Chan-Yeung, M.,Ferguson, A.,Watson, A.,Dimich, WArd H.,Dybuncio, A.,Rousseau, R.,Becker, A. Breastfeeding and risk of asthma and other allergic diseases at aged 7 years in a high-risk birth-cohort [Abstract]. American Thoracic Society 2005 International Conference; May 20-25; San Diego, California. 2005:[C49] [Poster: A85].

391 Chan-Yeung, M.,Ferguson, A.,Watson, W.,Dimich-Ward, H.,Rousseau, R.,Lilley, M.,Dybuncio, A.,Becker, A. The Canadian Childhood Asthma Primary Prevention Study: outcomes at 7 years of age. J Allergy Clin Immunol. 2005;116(1):49-55.

392 Chan-Yeung, M.,Manfreda, J.,Dimich-Ward, H.,Ferguson, A.,Watson, W.,Becker, A. A randomized controlled study on the effectiveness of a multifaceted intervention program in the primary prevention of asthma in high-risk infants. Arch Pediatr Adolesc Med. 2000;154(7):657-63. questionable

Study design

Retracted

Independent variable

Independent variable

Peer review

Independent variable

Independent variable 
394 Chaparro, C. M.,Neufeld, L. M.,Tena Alavez, G.,Eguia-Liz Cedillo, R.,Dewey, K. G. Effect of timing of umbilical cord clamping on iron status in Mexican infants: a randomised controlled trial. Lancet. 2006;367(9527):1997-2004.

395 Chapman NL,Barnett DC. In defense of bottle-feeding. J Pract Nurs. 1982;32:24-7, 38.

Study design

396 Chapman, D. J. Breastfeeding, brain imaging, and maternal behavior. J Hum Lact. 2011;27(3):304-5.

Study design, Dependent variable

397 Chapman, D. J. Does breastfeeding result in smarter children? A closer look. J Hum Lact. 2013;29(4):444-5.

Study design

398 Chapman, D. J. Exclusive breastfeeding through 6 months: infant intake and growth patterns. J Hum Lact. 2012;28(2):132-3.

Study design

399 Chapman, D. J. Longer cumulative breastfeeding duration associated with improved bone strength. J Hum Lact. 2012;28(1):18-9.

Study design

400 Chapman, D. J.,Morel, K.,Bermudez-Millan, A.,Young, S.,Damio, G.,Perez-Escamilla, R. Breastfeeding education and support trial for overweight and obese women: a randomized trial. Pediatrics. 2013;131(1):e162-70.

Independent variable

Dependent variable

401 Chapman, D. J.,Nommsen-Rivers, L. Impact of maternal nutritional status on human milk quality and infant outcomes: an update on key nutrients. Adv Nutr. 2012;3(3):351-2.

402 Chatzimichael, A.,Tsalkidis, A.,Cassimos, D.,Gardikis, S., Tripsianis, G.,Deftereos, S., Ktenidou-Kartali, S., Tsanakas, I. The role of breastfeeding and passive smoking on the development of severe bronchiolitis in infants. Minerva Pediatr. 2007;59(3):199-206.

403 Chavalittamrong, B.,Jirapinyo, P. The weight of Thai infants exclusively breast-fed and formula-fed from birth to four months. J Med Assoc Thai. 1987;70(5):247-51.

Study design

Health status

Included for systematic reviews not completed

404 Chavez-Payan, P.,Grineski, S. E.,Collins, T. W. Early Life and Environmental Risk Factors Modify the Effect of Acculturation on Hispanic Children's Asthma. Hisp Health Care Int. 2015;13(3):119-30.

405 Chellakooty, M.,Juul, A.,Boisen, K. A.,Damgaard, I. N.,Kai, C. M.,Schmidt, I. M.,Petersen, J. H.,Skakkebæk, N. E.,Main, K. M. A prospective study of serum insulin-like growth factor I (IGF-I) and IGF-binding protein-3 in 942 healthy infants: Associations with birth weight, gender, growth velocity, and breastfeeding. Journal of Clinical Endocrinology and Metabolism. 2006;91(3):820-826.

406 Chen, A.,Rogan, W. J. Breastfeeding and the risk of postneonatal death in the United States. Pediatrics. 2004;113(5):e435-9.

Study design

Study design

Dependent variable systematic reviews not completed

407 Chen, B. Y.,Chan, C. C.,Han, Y. Y.,Wu, H. P.,Guo, Y. L. The risk factors and quality of life in children with allergic rhinitis in relation to seasona Study design attack patterns. Paediatr Perinat Epidemiol. 2012;26(2):146-55. 
409 Chen, C. J.,Wu, F. T.,Hsiung, C. A.,Chang, W. C.,Wu, H. S.,Wu, C. Y.,Lin, J. S.,Huang, F. C.,Huang, Y. C. Risk factors for salmonella gastroenteritis in children less than five years of age in Taiwan. Pediatr Infect Dis J. 2012;31(12):e239-43.

Included for systematic reviews not completed

410 Chen, K.,Chai, L.,Li, H.,Zhang, Y.,Xie, H. M.,Shang, J., Tian, W.,Yang, P.,Jiang, A. C.. Effect of bovine lactoferrin from iron-fortified formulas on morbidity of diarrhea and respiratory tract infections of weaned infants in a randomized controlled trial. Nutrition.

Included for systematic reviews not 2015;\#volume\#(\#issue\#):\#pages\#.

completed

411 Chen, M. Test a model of breast-feeding duration for Vietnamese mothers in Taiwan. Communicating Nursing Research. 2005;38:461-461 1p.

Study design

412 Chen, S. M.,Du, J. W.,Jin, Y. M., Qiu, L.,Du, Z. H.,Li, D. D.,Chen, H. Y.,Watanabe, C.,Umezaki, M. Risk Factors for Severe Hand-Foot-Mouth Disease in Children in Hainan, China, 2011-2012. Asia Pac J Public Health. 2015;27(7):715-22.

Independent variable Dependent variable

413 Chen, X. C.,Liu, D. S.,Fu, A. Z.,Yan, H. C.,Yin, T. A.,Jing, Y. S.,Xu, Q. M. A longitudinal study on infant growth during the first sixth months of life, in relation to the nutrition of the lactating mothers and to the breastmilk output. Prog Food Nutr Sci. 1989;13(2):113-37.

Independent variable

414 Chen, Y. C., Tsai, C. H.,Lee, Y. Gestational medication use, birth conditions, and early postnatal exposures for childhood asthma. Clin Dev Immunol. 2012;2012:913426.

415 Chen, Y. Relationship between type of infant feeding and hospitalization for gastroenteritis in Shanghai infants. J Hum Lact. 1994;10(3):177-9.

Independent variable

416 Chen, Y. Synergistic effect of passive smoking and artificial feeding on hospitalization for respiratory illness in early childhood. Chest. 1989;95(5):1004-7.

417 Chen, Y.,Yu, S. Z.,Li, W. X. Artificial feeding and hospitalization in the first 18 months of life. Pediatrics. 1988;81(1):58-62.

Included for

systematic reviews not completed

418 Cheng, S.,Volgyi, E.,Tylavsky, F. A.,Lyytikainen, A.,Tormakangas, T.,Xu, L.,Cheng, S. M.,Kroger, H.,Alen, M.,Kujala, U. M. Trait-specific tracking and determinants of body composition: a 7-year follow-up study of pubertal growth in girls. BMC Med. 2009;7:5

Included for systematic reviews not completed

419 Cherian, A.,Lawande, R. V. Diarrhoeal disease in bottle fed children. J R Soc Health. 1987;107(2):62-3.

Country

420 Chertok, I. R.,Raz, I.,Shoham, I.,Haddad, H.,Wiznitzer, A. Effects of early breastfeeding on neonatal glucose levels of term infants born to Study design, women with gestational diabetes. J Hum Nutr Diet. 2009;22(2):166-9.

Independent variable

421 Chertok, I. R.,Shoham-Vardi, I. Infant hospitalization and breastfeeding post-caesarean section. Br J Nurs. 2008;17(12):786-91.

Dependent variable

422 Chesney, R. W. Rickets: an old form for a new century. Pediatr Int. 2003;45(5):509-11.

Study design 
424 Chiasson, M. A.,Scheinmann, R.,Hartel, D.,McLeod, N.,Sekhobo, J.,Edmunds, L. S.,Findley, S. Predictors of Obesity in a Cohort of Children Enrolled in WIC as Infants and Retained to 3 Years of Age. J Community Health. 2015.

Included for systematic reviews not completed

Group size ferritin and zinc levels. Acta Paediatr. 1992;81(6-7):475-9.

426 Chierici, R.,Sawatzki, G.,Thurl, S.,Tovar, K.,Vigi, V. Experimental milk formulae with reduced protein content and desialylated milk proteins: influence on the faecal flora and the growth of term newborn infants. Acta Paediatr. 1997;86(6):557-63.

427 Chin, K. C.,Galea, P.,Goel, K. M. Changing pattern in infant feeding practices. Health Bull (Edinb). 1981;39(1):51-7.

Group size

Dependent variable

428 Chiu, W. C.,Liao, H. F.,Chang, P. J.,Chen, P. C., Chen, Y. C. Duration of breast feeding and risk of developmental delay in Taiwanese children: a Study design nationwide birth cohort study. Paediatr Perinat Epidemiol. 2011;25(6):519-27.

429 Chivers, P.,Hands, B.,Parker, H.,Bulsara, M.,Beilin, L. J.,Kendall, G. E.,Oddy, W. H. Body mass index, adiposity rebound and early feeding in a longitudinal cohort (Raine Study). Int J Obes (Lond). 2010;34(7):1169-76.

Included for systematic reviews not completed

430 Chomtho, S. Breastfeeding to prevent double burden of malnutrition. Southeast Asian J Trop Med Public Health. 2014;45 Suppl 1:132-6. Study design

431 Chong, H. L.,Soo, T. L.,Rasat, R. Childhood obesity-prevalence among 7 and 8 year old primary school students in Kota Kinabalu. Medical Study design Journal of Malaysia. 2012;67(2):147-150.

432 Christopher, G. C. First food: the essential role of breastfeeding. Breastfeed Med. 2009;4 Suppl 1:S9-s10.

Study design

433 Chu, L.,Retnakaran, R.,Zinman, B.,Hanley, A. J. G.,Hamilton, J. K. Impact of maternal physical activity and infant feeding practices on infant weight gain and adiposity. International Journal of Endocrinology. 2012;2012.

434 Chuansumrit, A.,Arnutti, P.,Apivanich, S. Iron status of one-year-old infants in a well baby clinic. J Med Assoc Thai. 2002;85 Suppl 4:S1081-8.

Study design

435 Chye, J. K.,Lim, C. T. Breastfeeding at 6 months and effects on infections. Singapore Med J. 1998;39(12):551-6.

Included for systematic reviews not completed

436 Cilleruelo, M. L.,Fernandez-Fernandez, S., Jimenez-Jimenez, J.,Rayo, A. I.,Larramendi, C. H. Prevalence and Natural History of Celiac Disease Study design in a Cohort of at-Risk Children. J Pediatr Gastroenterol Nutr. 2015.

437 Ciria-Martin, A.,Caravia-Bernardo, F.,Alvarez-Castello, M.,Insua-Arregui, C.,Tamargo-Barbeito, T. O.,Massip-Nicot, J. [Risk factors for recurrent Language upper airways infections in pre-school children]. Rev Alerg Mex. 2012;59(3):113-22.

438 Civelek, E.,Cakir, B.,Orhan, F.,Yuksel, H.,Boz, A. B.,Uner, A.,Sekerel, B. E. Risk factors for current wheezing and its phenotypes among elementary school children. Pediatr Pulmonol. 2011;46(2):166-74.
Study design 
440 Clark, K. M.,Castillo, M.,Calatroni, A.,Walter, T.,Cayazzo, M.,Pino, P.,Lozoff, B. Breast-feeding and mental and motor development at 51/2 Independent variable years. Ambul Pediatr. 2006;6(2):65-71.

441 Clark-Kellerman, M. J. A case for formula feeding. Ky Nurse. 1985;33(3):13-4.

Study design

442 Clavano, N. R. Mode of feeding and its effect on infant mortality and morbidity. J Trop Pediatr. 1982;28(6):287-93.

Country

443 Closa-Monasterolo, R.,Gispert-Llaurado, M.,Luque, V.,Ferre, N.,Rubio-Torrents, C.,Zaragoza-Jordana, M.,Escribano, J. Safety and efficacy of inulin and oligofructose supplementation in infant formula: results from a randomized clinical trial. Clin Nutr. 2013;32(6):918-27.

Independent variable,

Dependent variable

444 Close, C. Babies, bottles, and boobs. Br Med J (Clin Res Ed). 1987;295(6613):1666-7.

Study design

445 Cochi, S. L.,Fleming, D. W.,Hightower, A. W.,Limpakarnjanarat, K.,Facklam, R. R.,Smith, J. D.,Sikes, R. K.,Broome, C. V. Primary invasive Haemophilus influenzae type b disease: a population-based assessment of risk factors. J Pediatr. 1986;108(6):887-96.

446 Cockburn, F. Neonatal brain and dietary lipids. Arch Dis Child Fetal Neonatal Ed. 1994;70(1):F1-2

Study design

447 Cogswell, J. J.,Mitchell, E. B.,Alexander, J. Parental smoking, breast feeding, and respiratory infection in development of allergic diseases. Arch Dis Child. 1987;62(4):338-44.

448 Colchero, M. A.,Contreras-Loya, D.,Lopez-Gatell, H.,Gonzalez de Cosio, T. The costs of inadequate breastfeeding of infants in Mexico. Am Clin Nutr. 2015;101(3):579-86.

449 Collipp, P. J.,Kuo, B.,Castro-Magana, M.,Chen, S. Y.,Salvatore, S. Hair zinc levels in infants. Clin Pediatr (Phila). 1983;22(7):512-3.

Study design

450 Cone, T. E., Jr. The nursing bottle caries syndrome. JAMA. 1981;245(22):2334

451 Connolly, C. Saving babies: child-saving and infant nutrition. Pediatr Nurs. 2005;31(4):309-11. Study design

Study design

452 Conover B. Exposures during pregnancy and lactation. Nebr Med J. 1992;77:65-7.

Study design

453 Controversial breastfeeding study. Practising Midwife. 2001;4(5):6-6 1p. Study design

454 Coombes R. Bottling out over formula feed. Nurs Times. 1999;95:12-3.

Study design

455 Coppi, S.,Iacoponi, F.,Fommei, C.,Strambi, M. Growth trend during the first six months of life in male infants with different type of feeding Minerva Pediatr. 2013;65(1):51-9.

Included for systematic reviews not completed

456 Cornish, R. P.,Tilling, K.,Boyd, A.,Davies, A.,Macleod, J. Using linked educational attainment data to reduce bias due to missing outcome data in estimates of the association between the duration of breastfeeding and IQ at 15 years. Int J Epidemiol. 2015;44(3):937-45.

Included for systematic reviews not completed

457 Corrao, G.,Tragnone, A.,Caprilli, R.,Trallori, G.,Papi, C.,Andreoli, A.,Di Paolo, M.,Riegler, G.,Rigo, G. P.,Ferrau, O.,Mansi, C.,Ingrosso, Independent variable M.,Valpiani, D. Risk of inflammatory bowel disease attributable to smoking, oral contraception and breastfeeding in Italy: a nationwide case- 
control study. Cooperative Investigators of the Italian Group for the Study of the Colon and the Rectum (GISC). Int J Epidemiol. 1998;27(3):397404.

458 Correa-Faria, P.,Martins-Junior, P. A., Vieira-Andrade, R. G.,Marques, L. S.,Ramos-Jorge, M. L. Perinatal factors associated with developmental defects of enamel in primary teeth: a case-control study. Braz Oral Res. 2013;27(4):363-8.

Included for systematic reviews not completed

459 Corvalan, C.,Kain, J.,Weisstaub, G.,Uauy, R. Impact of growth patterns and early diet on obesity and cardiovascular risk factors in young children from developing countries. Proc Nutr Soc. 2009;68(3):327-37.

Study design

460 Corvalan, C.,Uauy, R.,Stein, A. D.,Kain, J.,Martorell, R. Effect of growth on cardiometabolic status at 4 y of age. Am J Clin Nutr. 2009;90(3):547- Study design 55.

461 Counsilman, J. J.,Chan, S. Y.,Haiyon, H.,Rahim, N. A.,Salim, R.,Tai, T. Y.,Tan, M. L.,Zainy, Z., Viegas, O. Breast feeding among poor Singaporeans. J Trop Pediatr. 1986;32(6):310-2.

462 Counsilman, J. J.,Chua, S.,Viegas, O. Breast feeding among well-to-do Singaporeans. J Trop Pediatr. 1986;32(6):313-6.

Dependent variable

Dependent variable

463 Couper, J. J.,Beresford, S.,Hirte, C.,Baghurst, P. A.,Pollard, A.,Tait, B. D.,Harrison, L. C., Colman, P. G. Weight gain in early life predicts risk of islet autoimmunity in children with a first-degree relative with type 1 diabetes. Diabetes Care. 2009;32(1):94-9.

464 Couper, J. J.,Steele, C.,Beresford, S.,Powell, T.,McCaul, K.,Pollard, A.,Gellert, S., Tait, B.,Harrison, L. C.,Colman, P. G. Lack of association between duration of breast-feeding or introduction of cow's milk and development of islet autoimmunity. Diabetes. 1999;48(11):2145-9.

465 Cowden, M. Infant feeding. Midwives Chron. 1982;95(1136):319-20.

466 Cow's milk allergy in the first year of life. An Italian Collaborative Study. Acta Paediatr Scand Suppl. 1988;348:1-14.

Dependent variable

Dependent variable Study design

Study design, Health status

467 Crestani, A. H.,Souza, A. P.,Beltrami, L.,Moraes, A. B. Analysis of the association among types of breastfeeding, presence of child development risk, socioeconomic and obstetric variables. J Soc Bras Fonoaudiol. 2012;24(3):205-10.

Study design,

Dependent variable

468 Crewe, E.,Murphy, A. M. Further studies on neonatal rotavirus infections. Med J Aust. 1980;1(2):61-3.

Study design,

Dependent variable

469 Crossland, D. S.,Richmond, S.,Hudson, M.,Smith, K.,Abu-Harb, M. Weight change in the term baby in the first 2 weeks of life. Acta Paediatr. 2008;97(4):425-9.

Included for systematic reviews not completed

470 Crouch, A. A.,Seow, W. K.,Whitman, L. M., Thong, Y. H. Effect of human milk and infant milk formulae on adherence of Giardia intestinalis. Trans R Soc Trop Med Hyg. 1991;85(5):617-9.

471 Crouch, S.,Lightfoot, T.,Simpson, J.,Smith, A.,Ansell, P.,Roman, E. Infectious illness in children subsequently diagnosed with acute lymphoblastic leukemia: modeling the trends from birth to diagnosis. Am J Epidemiol. 2012;176(5):402-8.

Independent variable Non-human

Independent variable

472 Crow, D. R. Baby bottle tooth decay prevention--a new program for the Texas Department of Health. Tex Dent J. 1992;109(8):141.

Study design 
474 Crume, T. L.,Bahr, T. M.,Mayer-Davis, E. J.,Hamman, R. F.,Scherzinger, A. L.,Stamm, E.,Dabelea, D. Selective protection against extremes in childhood body size, abdominal fat deposition, and fat patterning in breastfed children. Arch Pediatr Adolesc Med. 2012;166(5):437-43.

Study design

Crume, T. L.,Ogden, L. G.,Mayer-Davis, E. J.,Hamman, R. F.,Norris, J. M.,Bischoff, K. J.,McDuffie, R.,Dabelea, D. The impact of neonatal breast-feeding on growth trajectories of youth exposed and unexposed to diabetes in utero: the EPOCH Study. Int J Obes (Lond). 2012;36(4):529-34.

476 Crume, T. L.,Ogden, L.,Maligie, M.,Sheffield, S.,Bischoff, K. J.,McDuffie, R.,Daniels, S.,Hamman, R. F.,Norris, J. M.,Dabelea, D. Long-term impact of neonatal breastfeeding on childhood adiposity and fat distribution among children exposed to diabetes in utero. Diabetes Care. 2011;34(3):641-5.

477 Cruz, M. L.,Wong, W. W.,Mimouni, F.,Hachey, D. L.,Setchell, K. D.,Klein, P. D.,Tsang, R. C. Effects of infant nutrition on cholesterol synthesis rates. Pediatr Res. 1994;35(2):135-40.

478 Cuhaci Çakir, B.,Beyazova, U.,Kemalo?lu, Y. K.,Özkan, S.,Gündüz, B.,Özdek, A. Effectiveness of pandemic influenza A/H1N1 vaccine for prevention of otitis media in children. European journal of pediatrics. 2012;171(11):1667-71.

479 Cullinan, T. R.,Saunders, D. I. Prediction of infant hospital admission risk. Arch Dis Child. 1983;58(6):423-7.

Included for

systematic reviews not completed

\section{Study design,}

Independent variable

Group size

Independent variable

Study design,

Independent variable

\begin{tabular}{|c|c|c|}
\hline 480 & Cunningham, A. S. Breast-feeding and health. J Pediatr. 1987;110(4):658-9. & Study design \\
\hline 481 & Current issues in feeding the normal infant. Pediatrics. 1985;75(1 Pt 2):135-215. & Study design \\
\hline 482 & Curtis, J. A.,Kooh, S. W.,Fraser, D.,Greenberg, M. L. Nutritional rickets in vegetarian children. Can Med Assoc J. 1983;128(2):150-2. & Study design \\
\hline 483 & Cushing, A. H.,Anderson, L. Diarrhea in breast-fed and non-breast-fed infants. Pediatrics. 1982;70(6):921-5. & Group size \\
\hline 484 & $\begin{array}{l}\text { Cushing, A. H.,Samet, J. M.,Lambert, W. E.,Skipper, B. J.,Hunt, W. C.,Young, S. A.,McLaren, L. C. Breastfeeding reduces risk of respiratory } \\
\text { illness in infants. Am J Epidemiol. 1998;147(9):863-70. }\end{array}$ & $\begin{array}{l}\text { Included for } \\
\text { systematic reviews not } \\
\text { completed }\end{array}$ \\
\hline 485 & $\begin{array}{l}\text { Cusick, S. E.,Mei, Z.,Cogswell, M. E. Continuing anemia prevention strategies are needed throughout early childhood in low-income preschool } \\
\text { children. J Pediatr. 2007;150(4):422-8, } 428 \text { e1-2. }\end{array}$ & $\begin{array}{l}\text { Included for } \\
\text { systematic reviews not } \\
\text { completed }\end{array}$ \\
\hline 486 & Cutting, W. A. Cholera and breastfeeding. Trop Doct. 2002;32(1):57-8. & Study design \\
\hline 487 & Dada, J. H. Nutrition and type 1 diabetes: can diet reduce risk?. Today's Dietitian. 2010;12(8):36-39 4p. & Study design \\
\hline 488 & Dadhich, J. P.,Agarwal, R. K. Mainstreaming early and exclusive breastfeeding for improving child survival. Indian Pediatr. 2009;46(1):11-7. & Study design, Country \\
\hline
\end{tabular}


491 Dagan, R.,Pridan, H. Relationship of breast feeding versus bottle feeding with emergency room visits and hospitalization for infectious diseases. Eur J Pediatr. 1982;139(3):192-4.

Included for systematic reviews not completed

Study design, Independent variable Swedish Childhood Diabetes Study Group. Acta Paediatr. 2000;89(10):1231-7.

493 Dahlquist, G.,Savilahti, E.,Landin-Olsson, M. An increased level of antibodies to $\beta$-lactoglobulin is a risk determinant for early-onset Type 1 (insulin-dependent) diabetes mellitus independent of islet cell antibodies and early introduction of cow's milk. Diabetologia. 1992;35(10):980984.

494 Dalmeijer, G. W.,Wijga, A. H.,Gehring, U.,Renders, C. M.,Koppelman, G. H.,Smit, H. A., van Rossem, L. Fatty acid composition in breastfeeding and school performance in children aged 12 years. Eur J Nutr. 2015.

Independent variable Dependent variable

Included for systematic reviews not completed

495 Daly, K. A.,Rich, S. S.,Levine, S.,Margolis, R. H.,Le, C. T.,Lindgren, B.,Giebink, G. S. The family study of otitis media: design and disease and risk factor profiles. Genet Epidemiol. 1996;13(5):451-68.

Study design, Health status

\section{Study design} unit admissions. Acad Emerg Med. 2008;15(10):887-94.

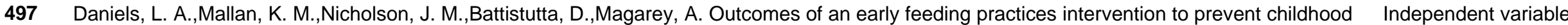
obesity. Pediatrics. 2013;132(1):e109-e118.

498 Darmstadt, G. L.,Munar, W. Behavior change and community participation: Assessing causal pathways affecting neonatal mortality. JAMA Journal of the American Medical Association. 2013;310(9):969-70.

499 Darnall, B. D.,Schatman, M. E. Protecting the infant from unknown risks. Pain Med. 2015;16(4):631-2.

500 DaVanzo, J.,Habicht, J. P. Infant mortality decline in Malaysia, 1946-1975: the roles of changes in variables and changes in the structure of relationships. Demography. 1986;23(2):143-60.

501 Davanzo, R.,Cannioto, Z.,Ronfani, L.,Monasta, L.,Demarini, S. Breastfeeding and neonatal weight loss in healthy term infants. J Hum Lact. 2013;29(1):45-53.

502 David, C. B.,David, P. H.,el Lozy, M. Determinants of breastfeeding duration and nutrition in a transition society. J Trop Pediatr. 1983;29(1):45-

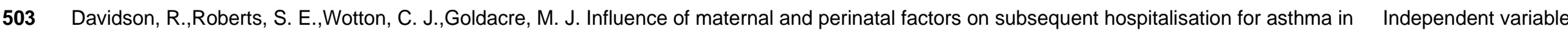
children: evidence from the Oxford record linkage study. BMC Pulm Med. 2010;10:14
Study design, Country

\section{Study design}

Independent variable

\section{Country}


505 Davis, J. N.,Gunderson, E. P.,Gyllenhammer, L. E.,Goran, M. I. Impact of gestational diabetes mellitus on pubertal changes in adiposity and

Study design metabolic profiles in Latino offspring. J Pediatr. 2013;162(4):741-5.

506 Davis, J. N.,Whaley, S. E.,Goran, M. I. Effects of breastfeeding and low sugar-sweetened beverage intake on obesity prevalence in Hispanic toddlers. Am J Clin Nutr. 2012;95(1):3-8.

507 Davis, J. Well advised: a journey to breastfeeding success. Pract Midwife. 2014;17(8):34, 36-8.

Study design

Study design

508 de Beer, M.,Vrijkotte, T. G.,Fall, C. H.,van Eijsden, M.,Osmond, C.,Gemke, R. J. Associations of infant feeding and timing of linear growth and relative weight gain during early life with childhood body composition. Int J Obes (Lond). 2015;39(4):586-92.

Included for systematic reviews not completed

509 de Boer, R. A topic in 10 questions: assessing common dietary deficiencies. J Fam Health Care. 2011;21(6):28-9.

Study design

510 de Bruin, N. C.,Degenhart, H. J.,Gal, S.,Westerterp, K. R.,Stijnen, T.,Visser, H. K. Energy utilization and growth in breast-fed and formula-fed infants measured prospectively during the first year of life. Am J Clin Nutr. 1998;67(5):885-96.

511 de Fátima Buco Busto Moreno, Patrícia,Trombini Schmidt, Kayna. BREAST-FEEDING AND FACTORS RELATED TO EARLY WEANING. Cogitare Enfermagem. 2014;19(3):531-537 7p.

512 de Freitas, C. L.,Romani, S.,Amigo, H. Breast-feeding and malnutrition in rural areas of northeast Brazil. Bull Pan Am Health Organ. $1986 ; 20(2): 138-46$

513 de Hoog, M. L., van Eijsden, M.,Stronks, K.,Gemke, R. J.,Vrijkotte, T. G. The role of infant feeding practices in the explanation for ethnic differences in infant growth: the Amsterdam Born Children and their Development study. Br J Nutr. 2011;106(10):1592-601.

514 de Jong, C.,Kikkert, H. K.,Fidler, V.,Hadders-Algra, M. Effects of long-chain polyunsaturated fatty acid supplementation of infant formula on cognition and behaviour at 9 years of age. Dev Med Child Neurol. 2012;54(12):1102-8.

Group size

Dependent variable

Study design,

Dependent variable

Included for

systematic reviews not completed

Included for

systematic reviews not completed

515 de Jong, C.,Kikkert, H. K.,Fidler, V.,Hadders-Algra, M. The Groningen LCPUFA study: no effect of postnatal long-chain polyunsaturated fatty Included for acids in healthy term infants on neurological condition at 9 years. Br J Nutr. 2010;104(4):566-72.

systematic reviews not completed

516 De Kroon, M. L.,Renders, C. M.,Buskermolen, M. P.,Van Wouwe, J. P.,van Buuren, S.,Hirasing, R. A. The Terneuzen Birth Cohort. Longer exclusive breastfeeding duration is associated with leaner body mass and a healthier diet in young adulthood. BMC Pediatr. 2011;11:33.

Independent variable

517 de la Hunty, A. The EU Childhood Obesity Project. Nutrition Bulletin. 2009;34(4):403-406 4p.

Study design,

Independent variable

518 de Looy, A. E. Infant nutrition. Nursing (Lond). 1986;3(12):446-9.

Study design 
519 De Lucia Rolfe, E.,Modi, N.,Uthaya, S.,Hughes, I. A.,Dunger, D. B.,Acerini, C.,Stolk, R. P.,Ong, K. K. Ultrasound estimates of visceral and subcutaneous-abdominal adipose tissues in infancy. J Obes. 2013;2013:951954.

Included for systematic reviews not completed

Independent variable

de Melo, M. C. N.,Taddei, J. A. A. C.,Diniz-Santos, D. R.,Vieira, C.,Carneiro, N. B.,Melo, R. F.,Silva, L. R. Incidence of diarrhea in children living in urban slums in Salvador, Brazil. Brazilian Journal of Infectious Diseases. 2008;12(1):89-93.

521 de Oliveira Bezerra, Joana Lidyanne,De Vasconcelos, Maria Gorete Lucena,Pereira Linhares, Francisca Márcia,Javorski, Marly,Leal, Luciana Pedrosa. Maternal perception of their children's body image in exclusive breastfeeding. Acta Paulista de Enfermagem. 2014;27(4):293-299 7p.

522 de Oliveira, D. M.,Dahan, P.,Ferreira, D. F.,de Oliveira, L. F.,de Paula, L. I.,de Figueiredo, A. A.,de Bessa, J., Jr.,Bastos Netto, J. M. Association between exclusive maternal breastfeeding during the first 4 months of life and primary enuresis. J Pediatr Urol. 2015.

523 de Rooy, L.,Hawdon, J. Nutritional factors that affect the postnatal metabolic adaptation of full-term small- and large-for-gestational-age infants. Pediatrics. 2002;109(3):E42.

524 De Souza, A. C.,Petersont, K. E.,Cufino, E.,do Amaral, M. I.,Gardner, J. Underlying and proximate determinants of diarrhoea-specific infant mortality rates among municipalities in the state of Ceara, north-east Brazil: an ecological study. J Biosoc Sci. 2001;33(2):227-44.

Study design

Dependent variable

Dependent variable

Study design, Independent variable

525 Deacon C. Breastfeeding. Are we just bottling out?. Nurs Times. 2001;97:26-7.

Study design

526 Dedoussis, G. V.,Yannakoulia, M.,Timpson, N. J.,Manios, Y.,Kanoni, S.,Scott, R. A.,Papoutsakis, C.,Deloukas, P.,Pitsiladis, Y. P.,Davey-Smith, G.,Hirschhorn, J. N.,Lyon, H. N. Does a short breastfeeding period protect from FTO-induced adiposity in children?. Int J Pediatr Obes. 2011;6(2-2):e326-35.

527 Deliu, M.,Belgrave, D.,Simpson, A.,Murray, C. S.,Kerry, G.,Custovic, A. Impact of rhinitis on asthma severity in school-age children. Allergy. 2014;69(11):1515-21.

528 Dell, S.,To, T. Breastfeeding and asthma in young children: findings from a population-based study. Arch Pediatr Adolesc Med. 2001;155(11):1261-5.

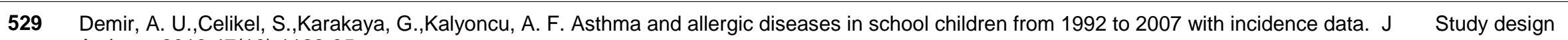
Asthma. 2010;47(10):1128-35.

530 Demment, M. M.,Haas, J. D.,Olson, C. M. Changes in family income status and the development of overweight and obesity from 2 to 15 years: a longitudinal study. BMC Public Health. 2014;14:417.

531 Demmers, T. A.,Jones, P. J.,Wang, Y.,Krug, S., Creutzinger, V.,Heubi, J. E. Effects of early cholesterol intake on cholesterol biosynthesis and plasma lipids among infants until 18 months of age. Pediatrics. 2005;115(6):1594-601.

532 Dennehy, P. H.,Cortese, M. M.,Begue, R. E.,Jaeger, J. L.,Roberts, N. E.,Zhang, R.,Rhodes, P.,Gentsch, J.,Ward, R.,Bernstein, D. I.,Vitek, C.,Bresee, J. S.,Staat, M. A. A case-control study to determine risk factors for hospitalization for rotavirus gastroenteritis in U.S. children. Pediatr Infect Dis J. 2006;25(12):1123-31.
Study design

Dependent variable

Study design

Included for systematic reviews not completed

Group size

Independent variable 
534 Derkson, G. D.,Ponti, P. Nursing bottle syndrome; prevalence and etiology in a non-fluoridated city. J Can Dent Assoc. 1982;48(6):389-93.

536 Dewailly, E.,Ayotte, P.,Bruneau, S.,Gingras, S.,Belles-Isles, M.,Roy, R. Susceptibility to infections and immune status in Inuit infants exposed to organochlorines. Environ Health Perspect. 2000;108(3):205-11.

Included for systematic reviews not completed

537 Dewey, K. G. Complementary feeding and breastfeeding. Pediatrics. 2000;106(5):1301

Study design

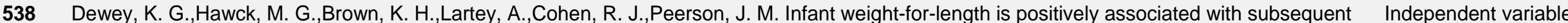
linear growth across four different populations. Matern Child Nutr. 2005;1(1):11-20.

539 Dewey, K. G.,Heinig, M. J.,Nommsen, L. A.,Lonnerdal, B. Adequacy of energy intake among breast-fed infants in the DARLING study: relationships to growth velocity, morbidity, and activity levels. Davis Area Research on Lactation, Infant Nutrition and Growth. J Pediatr. $1991 ; 119(4): 538-47$

540 Dewey, K. G.,Heinig, M. J.,Nommsen, L. A.,Peerson, J. M.,Lonnerdal, B. Breast-fed infants are leaner than formula-fed infants at 1 y of age: the DARLING study. Am J Clin Nutr. 1993;57(2):140-5.

541 Dewey, K. G.,Heinig, M. J.,Nommsen, L. A.,Peerson, J. M.,Lonnerdal, B. Growth of breast-fed and formula-fed infants from 0 to 18 months: the DARLING Study. Pediatrics. 1992;89(6 Pt 1):1035-41.

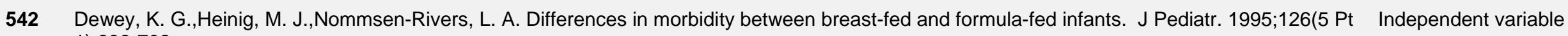
1):696-702.

543 Dewey, K. G.,Nommsen-Rivers, L. A.,Heinig, M. J.,Cohen, R. J. Risk factors for suboptimal infant breastfeeding behavior, delayed onset of lactation, and excess neonatal weight loss. Pediatrics. 2003;112(3 Pt 1):607-19.

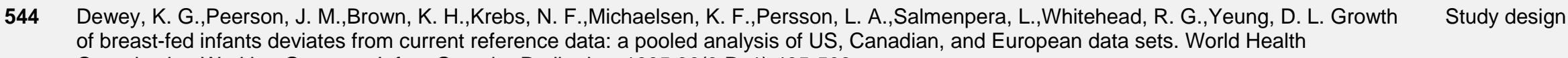
Organization Working Group on Infant Growth. Pediatrics. 1995;96(3 Pt 1):495-503.

545 Dewey, K. G.,Peerson, J. M.,Heinig, M. J.,Nommsen, L. A.,Lonnerdal, B.,Lopez de Romana, G.,de Kanashiro, H. C.,Black, R. E.,Brown, K. H. Growth patterns of breast-fed infants in affluent (United States) and poor (Peru) communities: implications for timing of complementary feeding. Am J Clin Nutr. 1992;56(6):1012-8.

546 Dharmage, S. C., Rajapaksa, L. C.,Fernando, D. N. Risk factors of acute lower respiratory tract infections in children under five years of age. Southeast Asian J Trop Med Public Health. 1996;27(1):107-10.

547 Diarrhoeal disease control (CDD) and acute respiratory infections (ARI). Combined CDD/ARI/breast-feeding survey, 1992. Wkly Epidemiol Rec. 1993;68(17):120-2.

Study design Independent variable

Health status

Study design Independent variable 
549 Diaz, S.,Herreros, C.,Aravena, R.,Casado, M. E.,Reyes, M. V.,Schiappacasse, V. Breast-feeding duration and growth of fully breast-fed infants

Independent variable in a poor urban Chilean population. Am J Clin Nutr. 1995;62(2):371-6.

550 Diaz, S.,Rodriguez, G.,Marshall, G.,del Pino, G.,Casado, M. E.,Miranda, P.,Schiappacasse, V.,Croxatto, H. B. Breastfeeding pattern and the duration of lactational amenorrhea in urban Chilean women. Contraception. 1988;38(1):37-51.

551 Diesel, J. C.,Eckhardt, C. L.,Day, N. L.,Brooks, M. M.,Arslanian, S. A.,Bodnar, L. M. Is gestational weight gain associated with offspring obesity at 36 months?. Pediatr Obes. 2015;10(4):305-10.

552 Dietary and other risk factors of ulcerative colitis. A case-control study in Japan. Epidemiology Group of the Research Committee of Inflammatory Bowel Disease in Japan. J Clin Gastroenterol. 1994;19(2):166-71. 553 Dini, E. L.,Holt, R. D.,Bedi, R. Caries and its association with infant feeding and oral health-related behaviours in 3-4-year-old Brazilian children.
Community Dent Oral Epidemiol. 2000;28(4):241-8.

554 Dinsmore, J.,Williams, E.,McCarthy, H.,Coghlan, D. A pilot study to explore factors affecting faltering growth in children. Journal of Human Nutrition \& Dietetics. 2011;24(3):280-281 2p.

555 Disantis, K. I.,Collins, B. N.,Fisher, J. O.,Davey, A. Do infants fed directly from the breast have improved appetite regulation and slower growth during early childhood compared with infants fed from a bottle?. Int J Behav Nutr Phys Act. 2011;8:89.

556 Dixon, D. L.,Griggs, K. M.,Forsyth, K. D.,Bersten, A. D. Lower interleukin-8 levels in airway aspirates from breastfed infants with acute bronchiolitis. Pediatr Allergy Immunol. 2010;21(4 Pt 2):e691-6.

557 Djalalinia, S.,Qorbani, M.,Heshmat, R.,Motlagh, M. E.,Ardalan, G.,Bazyar, N., Taheri, M.,Asayesh, H., Kelishadi, R. Association of Breast Feeding 2015;56(5):324-33

558 Does breastfeeding increase risk of early childhood caries? J Can Dent Assoc. 2013;79:d123.

559 Does breastfeeding prevent obesity?..and what about dairy foods?. Child Health Alert. 2004;22:3-4.

560 Dogaru, C. M.,Strippoli, M. P.,Spycher, B. D.,Frey, U.,Beardsmore, C. S.,Silverman, M.,Kuehni, C. E. Breastfeeding and lung function at school age: does maternal asthma modify the effect?. Am J Respir Crit Care Med. 2012;185(8):874-80.

561 Dogruel, D.,Bingol, G.,Altintas, D. U.,Yilmaz, M.,Kendirli, S. G. Prevalence of and risk factors for atopic dermatitis: A birth cohort study of infants in southeast Turkey. Allergol Immunopathol (Madr). 2015.

562 Domellof, E., Timby, N.,Domellof, M.,Lonnerdal, B.,Hernell, O. Formula feeding supplemented with milk fat globule membranes improves cognitive score in term infants at 12 months. Developmental medicine and child neurology. 2013;55:50.

563 Dondi, A.,Tripodi, S.,Panetta, V.,Asero, R.,Businco, A. D.,Bianchi, A.,Carlucci, A.,Ricci, G.,Bellini, F.,Maiello, N.,del Giudice, M. M.,Frediani, T.,Sodano, S.,Dello Iacono, I.,Macri, F.,Massaccesi, V.,Caffarelli, C.,Rinaldi, L.,Patria, M. F.,Varin, E.,Peroni, D.,Chinellato, I.,Chini,

L.,Moschese, V.,Lucarelli, S.,Bernardini, R.,Pingitore, G.,Pelosi, U.,Tosca, M.,Paravati, F.,La Grutta, S.,Meglio, P.,Calvani, M.,Plebani,

Peer review

\section{No full text}

Included for

systematic reviews not completed

Dependent variable

Study design

Study design

Dependent variable

Independent variable

Study design

Study design 
M.,Matricardi, P. M. Pollen-induced allergic rhinitis in 1360 Italian children: comorbidities and determinants of severity. Pediatr Allergy Immunol. 2013;24(8):742-51

564 Dong, G. H.,Qian, Z. M.,Liu, M. M.,Wang, D.,Ren, W. H.,Bawa, S.,Fu, J.,Wang, J.,Lewis, R.,Zelicoff, A.,Simckes, M.,Trevathan, E. Breastfeeding as a modifier of the respiratory effects of air pollution in children. Epidemiology. 2013;24(3):387-94.

565 Dong, G. H.,Qian, Z. M.,Trevathan, E.,Zeng, X. W., Vaughn, M. G.,Wang, J.,Zhao, Y.,Liu, Y. Q.,Ren, W. H.,Qin, X. D. Air pollution associated hypertension and increased blood pressure may be reduced by breastfeeding in Chinese children: the Seven Northeastern Cities Chinese Children's Study. Int J Cardiol. 2014;176(3):956-61.

566 Donma, M. M.,Donma, O. Infant feeding and growth: a study on Turkish infants from birth to 6 months. Pediatr Int. 1999;41(5):542-8.

Independent variable

567 Donma, M. M.,Donma, O. The influence of feeding patterns on head circumference among Turkish infants during the first 6 months of life. Brain Dev. 1997;19(6):393-7.

Included for systematic reviews not completed

568 Donohue, L. Baby Friendly Hospitals in China. Aust J Adv Nurs. 1994;12(2):7.

Study design

569 Doran, E. Breast is best for lightweights. Nurs Mirror. 1983;156(12):46-7

Health status

570 Dorea, J. G. Zinc in urban infants and children from Brasilia. Arch Latinoam Nutr. 1997;47(2 Suppl 1):39-40.

Study design

571 Dorea, J. G.,Marques, R. C.,Isejima, C. Neurodevelopment of Amazonian infants: antenatal and postnatal exposure to methyl- and ethylmercury. J Biomed Biotechnol. 2012;2012:132876.

Study design,

Independent variable

572 Dotan, I.,Alper, A.,Rachmilewitz, D.,Israeli, E.,Odes, S.,Chermesh, I.,Naftali, T.,Fraser, G.,Shitrit, A. B.,Peles, V.,Reif, S. Maternal inflammatory bowel disease has short and long-term effects on the health of their offspring: a multicenter study in Israel. J Crohns Colitis. 2013;7(7):542-50.

573 Douglas, R. M.,Woodward, A.,Miles, H.,Buetow, S.,Morris, D. A prospective study of proneness to acute respiratory illness in the first two years of life. Int J Epidemiol. 1994;23(4):818-26.

574 Doumid Borges Pretto, A. Correa Kaufmann, C. Ferreira Dutra, G. Pinto Albernaz, E. Prevalence of factors related to the bone mass formation of children from a cohort in Southern Brazil. Nutr Hosp. 2015;31(3):1122-8.

575 Draaisma, E.,Garcia-Marcos, L.,Mallol, J.,Sole, D.,Perez-Fernandez, V.,Brand, P. L. A multinational study to compare prevalence of atopic dermatitis in the first year of life. Pediatr Allergy Immunol. 2015;26(4):359-66.

576 Drewett, R. F.,Amatayakul, K. Energy intake, appetite and body mass in infancy. Early Hum Dev. 1999;56(1):75-82.

Independent variable Dependent variable

Dependent variable

ndependent variable

Study design,

Dependent variable

Independent variable

577 Drewett, R.,Amatayakul, K.,Chiowanich, P.,Tansuhaj, A.,Ruckphaopunt, S.,Wongsawasdii, L.,Baum, D.,Imong, S.,Jackson, D.,Woolridge, M. The Chiang Mai lactation project: study design and implementation. Paediatr Perinat Epidemiol. 1991;5(3):347-60.

578 Drover, J.,Hoffman, D. R.,Castaneda, Y. S.,Morale, S. E.,Birch, E. E. Three randomized controlled trials of early long-chain polyunsaturated Fatty Acid supplementation on means-end problem solving in 9-month-olds. Child Dev. 2009;80(5):1376-84.

579 Du, Y.,Ellert, U.,Lampert, T.,Mensink, G. B.,Schlaud, M. Association of breastfeeding and exposure to maternal smoking during pregnancy with children's general health status later in childhood. Breastfeed Med. 2012;7(6):504-13. 
580 Dubakiene, R.,Rudzeviciene, O.,Butiene, I.,Sezaite, I.,Petronyte, M.,Vaicekauskaite, D.,Zvirbliene, A. Studies on early allergic sensitization in the Lithuanian birth cohort. ScientificWorldJournal. 2012;2012:909524.

581 Dube, K.,Schwartz, J.,Mueller, M. J.,Kalhoff, H.,Kersting, M. Iron intake and iron status in breastfed infants during the first year of life. Clin Nutr. Group size 2010;29(6):773-8.

582 Dubois, L.,Girard, M. Early determinants of overweight at 4.5 years in a population-based longitudinal study. Int J Obes (Lond). 2006;30(4):610-

Included for

systematic reviews not completed

583 Duffy, L. C.,Byers, T. E.,Riepenhoff-Talty, M.,La Scolea, L. J.,Zielezny, M.,Ogra, P. L. The effects of infant feeding on rotavirus-induced gastroenteritis: a prospective study. Am J Public Health. 1986;76(3):259-63.

Included for

systematic reviews not completed

584 Duffy, L. C.,Faden, H.,Wasielewski, R.,Wolf, J.,Krystofik, D. Exclusive breastfeeding protects against bacterial colonization and day care exposure to otitis media. Pediatrics. 1997;100(4):E7.

Included for

systematic reviews not completed

585 Duffy, L. C.,Riepenhoff-Talty, M.,Byers, T. E.,La Scolea, L. J.,Zielezny, M. A.,Dryja, D. M.,Ogra, P. L. Modulation of rotavirus enteritis during breast-feeding. Implications on alterations in the intestinal bacterial flora. Am J Dis Child. 1986;140(11):1164-8.

Included for systematic reviews not completed

586

Dugdale, A. E. Infant feeding, growth and mortality: a 20-year study of an Australian Aboriginal community. Med J Aust. 1980;2(7):380-5.

Included for systematic reviews not completed

587 Duijts, L.,Jaddoe, V. W.,Hofman, A.,Moll, H. A. Prolonged and exclusive breastfeeding reduces the risk of infectious diseases in infancy. Pediatrics. 2010;126(1):e18-25.

Included for systematic reviews not completed

588 Dumrongwongsiri, O.,Suthutvoravut, U.,Chatvutinun, S.,Phoonlabdacha, P.,Sangcakul, A., Siripinyanond, A., Thiengmanee, U.,Chongviriyaphan, $\mathrm{N}$. Maternal zinc status is associated with breast milk zinc concentration and zinc status in breastfed infants aged 4-6 months. Asia Pac $\mathrm{J}$ Clin

Study design Nutr. 2015;24(2):273-80.

589 Duncan, B.,Ey, J.,Holberg, C. J.,Wright, A. L.,Martinez, F. D.,Taussig, L. M. Exclusive breast-feeding for at least 4 months protects against otitis media. Pediatrics. 1993;91(5):867-72.

\section{Included for}

systematic reviews not completed

590 Dunlop, A. L.,Reichrtova, E.,Palcovicova, L.,Ciznar, P.,Adamcakova-Dodd, A.,Smith, S. J.,McNabb, S. J. Environmental and dietary risk factors $\quad$ Study design for infantile atopic eczema among a Slovak birth cohort. Pediatr Allergy Immunol. 2006;17(2):103-11.

591 Dunne, A. Early infant nutrition: the importance of getting it right. Br J Nurs. 2012;21(7):390

Study design

592 Dunne, A. Nutrition in infancy: achieving nutrition needs for new mothers and children. Br J Community Nurs. 2012;Suppl:S22.

Study design

Dunson, D. B.,Chulada, P.,Arbes, S. J., Jr. Bayesian modeling of time-varying and waning exposure effects. Biometrics. 2003;59(1):83-91.

Study design 
594 Durmu, B.,Ay, L.,Duijts, L.,Moll, H. A.,Hokken-Koelega, A. C. S.,Raat, H.,Hofman, A.,Steegers, E. A. P.,Jaddoe, V. W. V. Infant diet and subcutaneous fat mass in early childhood: The Generation R Study. European Journal of Clinical Nutrition. 2012;66(2):253-260.

Included for systematic reviews not completed

Independent variable

595 Durmus, B.,Ay, L.,Hokken-Koelega, A. C.,Raat, H.,Hofman, A.,Steegers, E. A.,Jaddoe, V. W. Maternal smoking during pregnancy and subcutaneous fat mass in early childhood. The Generation R Study. Eur J Epidemiol. 2011;26(4):295-304.

596 Durmus, B.,Heppe, D. H.,Gishti, O.,Manniesing, R.,Abrahamse-Berkeveld, M.,van der Beek, E. M.,Hofman, A.,Duijts, L.,Gaillard, R.,Jaddoe, V. W. General and abdominal fat outcomes in school-age children associated with infant breastfeeding patterns. Am J Clin Nutr. 2014;99(6):13518.

597 Durmus, B.,van Rossem, L.,Duijts, L.,Arends, L. R.,Raat, H.,Moll, H. A.,Hofman, A.,Steegers, E. A., Jaddoe, V. W. Breast-feeding and growth in children until the age of 3 years: the Generation R Study. Br J Nutr. 2011;105(11):1704-11.

Included for

systematic reviews not completed

Included for systematic reviews not completed

Country

598 Dutta, P.,Lahiri, M.,Sen, D.,Pal, S. C. Prospective hospital based study on persistent diarrhoea. Gut. 1991;32(7):787-90.

Study design

599

Dwyer, T.,Ponsonby, A. L. SIDS epidemiology and incidence. Pediatr Ann. 1995;24(7):350-2, 354-6.

Included for systematic reviews not completed

601 Ebina, S.,Kashiwakura, I. Relationship between feeding modes and infant weight gain in the first month of life. Exp Ther Med. 2013;5(1):28-32.

Included for systematic reviews not completed

602 Eckhardt, C. L.,Rivera, J.,Adair, L. S.,Martorell, R. Full breast-feeding for at least four months has differential effects on growth before and after Independent variable six months of age among children in a Mexican community. J Nutr. 2001;131(9):2304-9.

603 Ecord, J. S. Critical connections. Study finds full breastfeeding for 6 months boosts infant's resistance to respiratory illnesses. Advances in Neonatal Care (Elsevier Science). 2003;3(1):2-2 1p.

604 Effects of breast-feeding: new results from a large randomised trial. Journal of Family Health Care. 2008;18(1):34-34 1p.

Study design

Study design

605 Eglinton, T. W.,Roberts, R.,Pearson, J.,Barclay, M.,Merriman, T. R.,Frizelle, F. A.,Gearry, R. B. Clinical and genetic risk factors for perianal Crohn's disease in a population-based cohort. Am J Gastroenterol. 2012;107(4):589-96.

606 Eickmann, S. H.,de Lira, P. I.,Lima Mde, C.,Coutinho, S. B., Teixeira Mde, L.,Ashworth, A. Breast feeding and mental and motor development at 12 months in a low-income population in northeast Brazil. Paediatr Perinat Epidemiol. 2007;21(2):129-37.

607 Eidelman, A. I. Breastfeeding mitigates a disaster. Breastfeed Med. 2013;8(3):344-5.

608 Eiger, M. S.,Rausen, A. R.,Silverio, J. Breast-vs. bottle-feeding. A study of morbidity in upper middle class infants. Clin Pediatr (Phila). 1984;23(9):492-5.
Dependent variable

Independent variable

Study design

Group size 
609 Ejlerskov, K. T.,Christensen, L. B.,Ritz, C.,Jensen, S. M.,Molgaard, C.,Michaelsen, K. F. The impact of early growth patterns and infant feeding on body composition at 3 years of age. Br J Nutr. 2015;114(2):316-27.
Included for systematic reviews not completed

Group size

Independent variable

Independent variable

Study design

613 Eldeirawi, K.,McConnell, R.,Furner, S.,Freels, S.,Stayner, L.,Hernandez, E.,Amoruso, L.,Torres, S.,Persky, V. W. Associations of doctordiagnosed asthma with immigration status, age at immigration, and length of residence in the United States in a sample of Mexican American School Children in Chicago. J Asthma. 2009;46(8):796-802.

614 El-Gilany, A. H.,El-Wehady, A. Maternal work and infant health in Al-Hassa, Saudi Arabia. Paediatrics ME. 2007;12(4):100-105.

Study design

615 Elidrissy, A. T.,Sedrani, S. H.,Lawson, D. E. Vitamin D deficiency in mothers of rachitic infants. Calcif Tissue Int. 1984;36(3):266-8.

Study design,

Independent variable

616 Elliott, K. G.,Kjolhede, C. L.,Gournis, E.,Rasmussen, K. M. Duration of breastfeeding associated with obesity during adolescence. Obes Res. 1997;5(6):538-41.

Included for

systematic reviews not completed

617 Elliott, L.,Henderson, J.,Northstone, K.,Chiu, G. Y.,Dunson, D.,London, S. J. Prospective study of breast-feeding in relation to wheeze, atopy and bronchial hyperresponsiveness in the Avon Longitudinal Study of Parents and Children (ALSPAC). J Allergy Clin Immunol. 2008;122(1):4954,54 e1-3.

618 Elwood, P. C.,Pickering, J.,Gallacher, J. E.,Hughes, J.,Davies, D. Long term effect of breast feeding: cognitive function in the Caerphilly cohort. J Epidemiol Community Health. 2005;59(2):130-3.

619 Emamghorashi, F.,Heydari, S. T. Growth of infants in relation to type of feeding in Jahrom, Islamic Republic of Iran. East Mediterr Health J. 2007;13(4):846-54

620 Emilsson, L.,Magnus, M. C.,Stordal, K. Perinatal risk factors for development of celiac disease in children, based on the prospective Norwegian Mother and Child Cohort Study. Clin Gastroenterol Hepatol. 2015;13(5):921-7.

621 Emmett, P. M.,Jones, L. R. Diet and growth in infancy: relationship to socioeconomic background and to health and development in the Avon Longitudinal Study of Parents and Children. Nutr Rev. 2014;72(8):483-506.

622 Emond, A.,Drewett, R.,Blair, P.,Emmett, P. Postnatal factors associated with failure to thrive in term infants in the Avon Longitudinal Study of Parents and Children. Arch Dis Child. 2007;92(2):115-9.
Dependent variable

Included for

systematic reviews not completed

Included for systematic reviews not completed

Independent variable

Study design

Included for

systematic reviews not completed 
624 Endesfelder, D.,zu Castell, W.,Ardissone, A.,Davis-Richardson, A. G.,Achenbach, P.,Hagen, M.,Pflueger, M.,Gano, K. A.,Fagen, J. R.,Drew, J. C.,Brown, C. T.,Kolaczkowski, B.,Atkinson, M.,Schatz, D.,Bonifacio, E.,Triplett, E. W.,Ziegler, A. G. Compromised gut microbiota networks in children with anti-islet cell autoimmunity. Diabetes. 2014;63(6):2006-14.

Dependent variable

625 Engel, J.,Anteunis, L.,Volovics, A.,Hendriks, J.,Marres, E. Risk factors of otitis media with effusion during infancy. Int J Pediatr Otorhinolaryngol. 1999;48(3):239-49.

Included for

systematic reviews not completed

626 Eriksen, H. L.,Kesmodel, U. S.,Underbjerg, M.,Kilburn, T. R.,Bertrand, J.,Mortensen, E. L. Predictors of intelligence at the age of 5: family, pregnancy and birth characteristics, postnatal influences, and postnatal growth. PLoS One. 2013;8(11):e79200.

627 Eriksson, J.,Forsen, T.,Osmond, C.,Barker, D. Obesity from cradle to grave. Int J Obes Relat Metab Disord. 2003;27(6):722-7.

Study design

Included for systematic reviews not completed

628 Eriksson, M.,Forsgren, M.,Sjoberg, S.,von Sydow, M.,Wolontis, S. Respiratory syncytial virus infection in young hospitalized children. Identification of risk patients and prevention of nosocomial spread by rapid diagnosis. Acta Paediatr Scand. 1983;72(1):47-51.

Study design, Health status

629 Ernst, E. Probiotics may prevent atopic disease. Focus on Alternative \& Complementary Therapies. 2001;6(3):204-205 2p.

Study design

630 Eronat, N.,Eden, E. A comparative study of some influencing factors of rampant or nursing caries in preschool children. J Clin Pediatr Dent. $1992 ; 16(4): 275-9$.

631 Escribano, J.,Luque, V.,Ferre, N.,Mendez-Riera, G.,Koletzko, B.,Grote, V.,Demmelmair, H.,Bluck, L.,Wright, A.,Closa-Monasterolo, R. Effect of protein intake and weight gain velocity on body fat mass at 6 months of age: the EU Childhood Obesity Programme. Int $\mathrm{J}$ Obes (Lond). 2012;36(4):548-53

632 Eskenazi, B.,Marks, A. R.,Bradman, A.,Fenster, L.,Johnson, C.,Barr, D. B.,Jewell, N. P. In utero exposure to dichlorodiphenyltrichloroethane (DDT) and dichlorodiphenyldichloroethylene (DDE) and neurodevelopment among young Mexican American children. Pediatrics.

Study design, Independent variable 2006;118(1):233-41.

633 Esmail, A.,Lambert, P. C.,Jones, D. R.,Mitchell, E. A. Prevalence of risk factors for sudden infant death syndrome in south east England before Included for systematic reviews not completed

Study design the 1991 national 'Back to Sleep' health education campaign. J Public Health Med. 1995;17(3):282-9.

634 Estevez-Gonzalez, M. D.,Santana Del Pino, A.,Henriquez-Sanchez, P.,Pena-Quintana, L.,Saavedra-Santana, P. Breastfeeding during the first six months of life, adiposity rebound and overweight/obesity at eight years of age. Int J Obes (Lond). 2015.

Study design

Included for systematic reviews not completed

635 Ethelberg, S.,Olesen, B.,Neimann, J.,Schiellerup, P.,Helms, M.,Jensen, C.,Böttiger, B.,Olsen, K. E. P.,Scheutz, F.,Gerner-Smidt, P.,Mølbak, K. Independent variable Risk factors for diarrhea among children in an industrialized country. Epidemiology. 2006;17(1):24-30. 
637 Etiler, N.,Velipasaoglu, S.,Aktekin, M. Risk factors for overall and persistent diarrhoea in infancy in Antalya, Turkey: a cohort study. Public Health. 2004;118(1):62-9.

Included for systematic reviews not completed

638 Evenhouse, E.,Reilly, S. Improved estimates of the benefits of breastfeeding using sibling comparisons to reduce selection bias. Health Serv

Study design Res. 2005;40(6 Pt 1):1781-802.

639 Exclusive breast feeding is protective against asthma and atopy in children. Bmj. 1999;319(7213):D.

Study design

640 ExI, B. M.,Deland, U.,Secretin, M. C.,Preysch, U.,Wall, M.,Shmerling, D. H. Improved general health status in an unselected infant population following an allergen-reduced dietary intervention programme: The ZUFF-STUDY-PROGRAMME - Part II: Infant growth and health status to age 6 months. European Journal of Nutrition. 2000;39(4):145-156.

641 Exl, B. M.,Deland, U.,Wall, M.,Preysch, U.,Secretin, M. C.,Shmerling, D. H. Zug-Frauenfeld nutritional survey ('Zuff Study'): Allergen-reduced nutrition in a normal infant population and its health-related effects: Results at the age of six months. Nutrition research (New York, N.Y.). 1998;18(8):1443-62.

642 Fagrell, T. G.,Ludvigsson, J.,Ullbro, C.,Lundin, S. A.,Koch, G. Aetiology of severe demarcated enamel opacities--an evaluation based on prospective medical and social data from 17,000 children. Swed Dent J. 2011;35(2):57-67.

Study design, Independent variable, Dependent variable

Study design

Included for systematic reviews not completed

643 Fall, C. H.,Borja, J. B.,Osmond, C.,Richter, L.,Bhargava, S. K.,Martorell, R.,Stein, A. D.,Barros, F. C.,Victora, C. G. Infant-feeding patterns and cardiovascular risk factors in young adulthood: data from five cohorts in low- and middle-income countries. Int J Epidemiol. $2011 ; 40(1): 47-62$.

644 Fallot, M. E.,Boyd, J. L., 3rd,Oski, F. A. Breast-feeding reduces incidence of hospital admissions for infection in infants. Pediatrics.

Study design 1980;65(6):1121-4

645 Falth-Magnusson, K.,Franzen, L.,Jansson, G.,Laurin, P.,Stenhammar, L. Infant feeding history shows distinct differences between Swedish celiac and reference children. Pediatr Allergy Immunol. 1996;7(1):1-5.

646 Falth-Magnusson, K.,Kjellman, N. I. Development of atopic disease in babies whose mothers were receiving exclusion diet during pregnancy--a randomized study. J Allergy Clin Immunol. 1987;80(6):868-75.

647 Farham, B. Rethink formula feeding. South African medical journal. 2006;96(10):1054.

648 Farooqi, I. S.,Hopkin, J. M. Early childhood infection and atopic disorder. Thorax. 1998;53(11):927-32.

Independent variable

649 Farris, R. P.,Frank, G. C.,Webber, L. S.,Srinivasan, S. R.,Berenson, G. S. Influence of milk source on serum lipids and lipoproteins during the Independent variable first year of life, Bogalusa heart study. Am J Clin Nutr. 1982;35(1):42-9.

650 Fawcett JN. Feeding from birth to 18 months. Nursing (Lond). 1981:956-8.

Study design 
651 Fawzi, W. W.,Forman, M. R.,Levy, A.,Graubard, B. I.,Naggan, L.,Berendes, H. W. Maternal anthropometry and infant feeding practices in Israel in relation to growth in infancy: the North African Infant Feeding Study. Am J Clin Nutr. 1997;65(6):1731-7.
Included for systematic reviews not completed

Country

Study design

Study design

Study design

Included for

systematic reviews not completed

Included for systematic reviews not completed

Dependent variable

Included for systematic reviews not completed

Included for systematic reviews not completed

Study design

Dependent variable

Included for systematic reviews not completed

Independent variable Independent variable Suppl):44-7. 
666 Fergusson, D. M.,Horwood, L. J.,Shannon, F. T. Breastfeeding and subsequent social adjustment in six- to eight-year-old children. J Child Psychol Psychiatry. 1987;28(3):379-86.

Included for

systematic reviews not completed

667 Fergusson, D. M.,Horwood, L. J.,Shannon, F. T. Risk factors in childhood eczema. J Epidemiol Community Health. 1982;36(2):118-22. Independent variable

668 Fergusson, D. M.,Horwood, L. J.,Shannon, F. T.,Taylor, B. Breast-feeding, gastrointestinal and lower respiratory illness in the first two years. Aust Paediatr J. 1981;17(3):191-5.

669 Fergusson, D. M.,McLeod, G. F.,Horwood, L. J. Breast feeding, infant growth, and body mass index at 30 and 35 years. Paediatr Perinat Epidemiol. 2014;28(6):545-52.

670 Fergusson, D. M.,Woodward, L. J. Breast feeding and later psychosocial adjustment. Paediatr Perinat Epidemiol. $1999 ; 13(2): 144-57$.

671 Ferris, A. G.,Laus, M. J.,Hosmer, D. W.,Beal, V. A. The effect of diet on weight gain in infancy. Am J Clin Nutr. 1980;33(12):2635-42.

Included for systematic reviews not completed

Included for systematic reviews not completed

Included for systematic reviews not completed

Independent variable

672 Fewtrell, M. S.,Kennedy, K.,Murgatroyd, P. R.,Williams, J. E.,Chomtho, S.,Lucas, A. Breast-feeding and formula feeding in healthy term infants Group size and bone health at age 10 years. Br J Nutr. 2013;110(6):1061-7.

673 Field, C. J.,Van Aerde, J. E.,Robinson, L. E.,Clandinin, M. T. Feeding a formula supplemented with long chain polyunsaturated fatty acids modifies the "ex vivo" cytokine responses to food proteins in infants at low risk for allergy. Pediatr Res. 2008;64(4):411-7.

674 Field, S. S. Interaction of genes and nutritional factors in the etiology of autism and attention deficit/hyperactivity disorders: a case control study. Med Hypotheses. 2014;82(6):654-61.

systematic reviews not completed

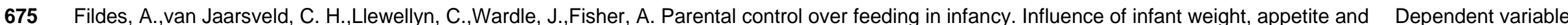
feeding method. Appetite. 2015;91:101-6.

676 Fildes, V. Weaning: on the bottle again. Nurs Mirror. 1980;151(24):18-21.

Study design

677 Findeisen, M.,Vennemann, M.,Brinkmann, B.,Ortmann, C.,Rose, I.,Kopcke, W.,Jorch, G.,Bajanowski, T. German study on sudden infant death (GeSID): design, epidemiological and pathological profile. Int J Legal Med. 2004;118(3):163-9.

Included for systematic reviews not completed

678 Firer, M. A.,Hosking, C. S.,Hill, D. J. Effect of antigen load on development of milk antibodies in infants allergic to milk. Br Med J (Clin Res Ed). 1981;283(6293):693-6.

679 Fisher C. Breastfeeding. Two. Feeding the relationship. Nurs Times. 1985;81:51. 
681 Fisk, C. M.,Crozier, S. R.,Inskip, H. M.,Godfrey, K. M.,Cooper, C.,Roberts, G. C.,Robinson, S. M. Breastfeeding and reported morbidity during infancy: findings from the Southampton Women's Survey. Matern Child Nutr. 2011;7(1):61-70.

Included for

systematic reviews not completed

682 Fitzgerald, S.,Kearney, M.,Mahony, M.,O'Halloran, E. T.,Barry, R. G. Gastroenteritis 1972-1978. Ir Med J. 1982;75(5):155-7.

Study design

683 Flaherman, V. J.,Bokser, S.,Newman, T. B. First-day newborn weight loss predicts in-hospital weight nadir for breastfeeding infants. Breastfeed Med. 2010;5(4):165-8.

684 Flaherman, V. J.,Fuentes-Afflick, E. Social and public health perspectives of promotion of breastfeeding. JAMA Pediatr. 2014;168(10):877-8. Independent variable Study design

685 Flaherman, V. J.,Kuzniewicz, M. W.,Li, S.,Walsh, E.,McCulloch, C. E.,Newman, T. B. First-day weight loss predicts eventual weight nadir for breastfeeding newborns. Arch Dis Child Fetal Neonatal Ed. 2013;98(6):F488-92.

686 Flaherman, V.,Aby, J.,Burgos, A.,Lee, K.,Cabana, M.,Newman, T. Randomized Trial of Early Limited Formula To Reduce Formula Use at 1 Week and Promote Breastfeeding at 3 Months in Infants with High Early Weight Loss. Pediatric Academic Societies Annual Meeting. 2012.

687 Fleddermann, M Demmelmair, $\mathrm{H}$, Grote, $\mathrm{V}$ Nikolic, $T$, Koletzko, B. A protein reduced, alpha-lactalbumin and LC-PUFA containing infant formula enables an adequate growth in infants and influences the energetic efficiency for growth: A randomized controlled trial. Clinical nutrition (Edinburgh, Scotland). 2013;32:S16

688 Fleming, P. J.,Blair, P. S.,Bacon, C.,Bensley, D.,Smith, I.,Taylor, E.,Berry, J.,Golding, J., Tripp, J. Environment of infants during sleep and risk of the sudden infant death syndrome: results of 1993-5 case-control study for confidential inquiry into stillbirths and deaths in infancy. Confidential Enquiry into Stillbirths and Deaths Regional Coordinators and Researchers. BMJ. 1996;313(7051):191-5.

Included for systematic reviews not completed

689 Fleming, P. J.,Blair, P. S.,Ward Platt, M.,Tripp, J.,Smith, I. J. Sudden infant death syndrome and social deprivation: assessing epidemiological factors after post-matching for deprivation. Paediatr Perinat Epidemiol. 2003;17(3):272-80.

Included for systematic reviews not completed

690 Fleming, T. Breast is best to avoid obesity: study. Pharmacy News. 2008:4-4 1p.

Study design

691 Flohr, C.,Nagel, G.,Weinmayr, G.,Kleiner, A.,Strachan, D. P.,Williams, H. C. Lack of evidence for a protective effect of prolonged breastfeeding Study design on childhood eczema: lessons from the International Study of Asthma and Allergies in Childhood (ISAAC) Phase Two. Br J Dermatol. 2011;165(6):1280-9

692 Flohr, C.,Perkin, M.,Logan, K.,Marrs, T.,Radulovic, S.,Campbell, L. E.,Maccallum, S. F.,McLean, W. H.,Lack, G. Atopic dermatitis and disease severity are the main risk factors for food sensitization in exclusively breastfed infants. J Invest Dermatol. 2014;134(2):345-50.

693 Flores, M. S.,Fairchok, M. P. The relationship of breastfeeding to antimicrobial exposure in the first year of life. Clin Pediatr (Phila) 2004;43(7):631-6.

694 Flores, M.,Pasquel, M. R.,Maulen, I.,Rivera, J. Exclusive breastfeeding in 3 rural localities in Mexico. J Hum Lact. 2005;21(3):276-83. 
695 Floret, D.,Lina, B.,Pinchinat, S.,Billaud, G.,Ait-Belghiti, F.,Largeron, N.,Bellemin, B.,Trang, C. N.,Fau, C.,Gaspard, C.,Mamoux, V.,Marcelon, L. Epidemiology and burden of rotavirus diarrhea in day care centers in Lyon, France. Eur J Pediatr. 2006;165(12):905-6.

696 Florey, C. D.,Leech, A. M.,Blackhall, A. Infant feeding and mental and motor development at 18 months of age in first born singletons. Int J Epidemiol. 1995;24 Suppl 1:S21-6.

697 Florez, C. E.,Hogan, D. P. Women's status and infant mortality in rural Colombia. Soc Biol. 1990;37(3-4):188-203.

Study design,

Independent variable

Included for

systematic reviews not completed

Study design,

Independent variable

698 Fogaca, H. R.,Marson, F. A.,Toro, A. A.,Sole, D.,Ribeiro, J. D. Epidemiological aspects of and risk factors for wheezing in the first year of life. J Study design Bras Pneumol. 2014;40(6):617-25.

699 Foley, S.,Quinn, S.,Jones, G. Tracking of bone mass from childhood to adolescence and factors that predict deviation from tracking. Bone. 2009;44(5):752-7.

700 Folic, N.,Folic, M.,Markovic, S.,Andjelkovic, M.,Jankovic, S. Risk factors for the development of metabolic syndrome in obese children and adolescents. Srp Arh Celok Lek. 2015;143(3-4):146-52.

701 Fomon, S. J. Assessment of growth of formula-fed infants: evolutionary considerations. Pediatrics. 2004;113(2):389-93.

702 Fomon, S. J. Factors influencing food consumption in the human infant. Int J Obes. 1980;4(4):348-50.

703 Fomon, S. J.,Rogers, R. R.,Ziegler, E. E.,Nelson, S. E., Thomas, L. N. Indices of fatness and serum cholesterol at age eight years in relation to feeding and growth during early infancy. Pediatr Res. 1984;18(12):1233-8.

704 Fomon, S. J.,Ziegler, E. E.,Nelson, S. E. Erythrocyte incorporation of ingested 58Fe by 56-day-old breast-fed and formula-fed infants. Pediatr $\quad$ Group size Res. 1993;33(6):573-6.

705 Fomon, S. J.,Ziegler, E. E.,Nelson, S. E.,Rogers, R. R.,Frantz, J. A. Infant formula with protein-energy ratio of 1.7 g/100 kcal is adequate but may not be safe. J Pediatr Gastroenterol Nutr. 1999;28(5):495-501.

706 Fonseca, A. L.,Albernaz, E. P.,Kaufmann, C. C.,Neves, I. H.,Figueiredo, V. L. Impact of breastfeeding on the intelligence quotient of eight-yearold children. J Pediatr (Rio J). 2013;89(4):346-53. living in urban areas. Journal of Investigational Allergology and Clinical Immunology. 2010;20(4):357-358.

708 Fonseca, M. J.,Severo, M.,Barros, H.,Santos, A. C. Determinants of weight changes during the first 96 hours of life in full-term newborns. Birth. 2014;41(2):160-8.

709 Fonseca, W.,Kirkwood, B. R.,Victora, C. G.,Fuchs, S. R.,Flores, J. A.,Misago, C. Risk factors for childhood pneumonia among the urban poor in Fortaleza, Brazil: a case--control study. Bull World Health Organ. 1996;74(2):199-208.
Study design

Included for systematic reviews not completed Independent variable

systematic reviews not completed

Study design

ndependent variable

Study design

Study design Independent variable

Included for completed systematic reviews not 
711 Ford, R. P.,Taylor, B. J.,Mitchell, E. A.,Enright, S. A.,Stewart, A. W.,Becroft, D. M.,Scragg, R.,Hassall, I. B.,Barry, D. M.,Allen, E. M.,et al.,.

Study design Breastfeeding and the risk of sudden infant death syndrome. Int J Epidemiol. 1993;22(5):885-90.

712 Ford-Jones, E. L.,Wang, E.,Petric, M.,Corey, P.,Moineddin, R.,Fearon, M. Hospitalization for community-acquired, rotavirus-associated diarrhea: a prospective, longitudinal, population-based study during the seasonal outbreak. The Greater Toronto Area/Peel Region PRESI Study Group.

Study design, Health Pediatric Rotavirus Epidemiology Study for Immunization. Arch Pediatr Adolesc Med. 2000;154(6):578-85.

713 Forman, M. R.,Graubard, B. I.,Hoffman, H. J.,Beren, R.,Harley, E. E.,Bennett, P. The Pima Infant Feeding Study: breast feeding and gastroenteritis in the first year of life. Am J Epidemiol. 1984;119(3):335-49.

714 Forman, M. R.,Graubard, B. I.,Hoffman, H. J.,Beren, R.,Harley, E. E.,Bennett, P. The Pima infant feeding study: breastfeeding and respiratory infections during the first year of life. Int J Epidemiol. 1984;13(4):447-53.

715 Forman, M. R.,Guptill, K. S.,Chang, D. N.,Sarov, B.,Berendes, H. W.,Naggan, L.,Hundt, G. L. Undernutrition among Bedouin Arab infants: the Bedouin Infant Feeding Study. Am J Clin Nutr. 1990;51(3):343-9. status

Study design

Study design, Independent variable

Included for systematic reviews not completed

716 Forman, M. R.,Lewando-Hundt, G.,Graubard, B. I.,Chang, D.,Sarov, B.,Naggan, L.,Berendes, H. W. Factors influencing milk insufficiency and its long-term health effects: the Bedouin Infant Feeding Study. Int J Epidemiol. 1992;21(1):53-8.

717 Forns, J.,Torrent, M.,Garcia-Esteban, R.,Caceres, A.,Pilar Gomila, M.,Martinez, D.,Morales, E.,Julvez, J.,Grimalt, J. O.,Sunyer, J. Longitudinal association between early life socio-environmental factors and attention function at the age 11 years. Environ Res. 2012;117:54-9.

Dependent variable

Included for systematic reviews not completed

718 Forns, J.,Vegas, O.,Julvez, J.,Garcia-Esteban, R.,Rivera, M.,Lertxundi, N.,Guxens, M.,Fano, E.,Ferrer, M.,Grellier, J., Ibarluzea, J.,Sunyer, J. Association between child cortisol levels in saliva and neuropsychological development during the second year of life. Stress Health.

Independent variable 2014;30(2):142-8.

719 Foroushani, A. R.,Mohammad, K.,Mahmoodi, M.,Siassi, F. Effect of breastfeeding on cognitive performance in a British birth cohort. East Mediterr Health J. 2010;16(2):202-8.

Dependent variable

Included for systematic reviews not completed

720 Forssell, G.,Hakansson, A.,Mansson, N. O. Risk factors for respiratory tract infections in children aged 2-5 years. Scand J Prim Health Care. 2001;19(2):122-5.

721 Forster, D. A.,Johns, H.,Amir, L. H.,McLachlan, H. L.,Moorhead, A.,Ford, R.,McEgan, K. The MILC Study-Exploring the prevalence and outcomes associated with breast milk expression: A prospective cohort study. Women \& Birth. 2013;26:S7-S7 1p.

722 Fosarelli, P. D.,DeAngelis, C.,Winkelstein, J.,Mellits, E. D. Infectious illnesses in the first two years of life. Pediatr Infect Dis. 1985;4(2):153-9. 
723 Foulon, S.,Pingault, J. B.,Larroque, B.,Melchior, M.,Falissard, B.,Cote, S. M. Developmental predictors of inattention-hyperactivity from pregnancy to early childhood. PLoS One. 2015;10(5):e0125996.

Included for systematic reviews not completed

\section{Study design}

Independent variable

725 Frank, A. L.,Taber, L. H.,Glezen, W. P.,Kasel, G. L.,Wells, C. R.,Paredes, A. Breast-feeding and respiratory virus infection. Pediatrics. 1982;70(2):239-45

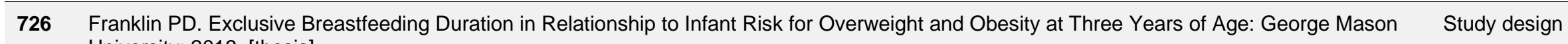
University; 2013. [thesis]

727 Franks, A. Breastfeeding in the neonatal unit. N Z Nurs J. 1989;82(8):23-4.

Study design

728 Fransoo, R. R.,Roos, N. P.,Martens, P. J.,Heaman, M.,Levin, B.,Chateau, D. How health status affects progress and performance in school: a population-based study. Can J Public Health. 2008;99(4):344-9.

Included for systematic reviews not completed

Included for systematic reviews not completed

Independent variable

730 Freeman, V. E.,Mulder, J.,van't Hof, M. A.,Hoey, H. M.,Gibney, M. J. A longitudinal study of iron status in children at 12,24 and 36 months. Public Health Nutr. 1998;1(2):93-100.

731 Friel, J. K.,Andrews, W. L.,Simmons, B. S.,L'Abbe, M. R.,Mercer, C.,MacDonald, A.,McCloy, U. R. Evaluation of full-term infants fed an evaporated milk formula. Acta Paediatr. 1997;86(5):448-53.

732 Froom, J.,Culpepper, L.,Green, L. A.,de Melker, R. A.,Grob, P.,Heeren, T.,van Balen, F. A cross-national study of acute otitis media: risk factors, severity, and treatment at initial visit. Report from the International Primary Care Network (IPCN) and the Ambulatory Sentinel Practice Network (ASPN). J Am Board Fam Pract. 2001;14(6):406-17.

733 Froozani, M. D.,Malekafzali, H.,Bahrini, B. Growth of a group of low income infants in the first year of life. J Trop Pediatr. 1980;26(3):96-8.

Study design Independent variable

734 Froozani, M. D.,Permehzadeh, K.,Motlagh, A. R.,Golestan, B. Effect of breastfeeding education on the feeding pattern and health of infants in their first 4 months in the Islamic Republic of Iran. Bull World Health Organ. 1999;77(5):381-5.

Included for

systematic reviews not completed

735 Fruhwirth, M.,Heininger, U.,Ehlken, B.,Petersen, G.,Laubereau, B.,Moll-Schuler, I.,Mutz, I.,Forster, J. International variation in disease burden of rotavirus gastroenteritis in children with community- and nosocomially acquired infection. Pediatr Infect Dis J. 2001;20(8):784-91.

736 Frye, C.,Heinrich, J. Trends and predictors of overweight and obesity in East German children. Int J Obes Relat Metab Disord. 2003;27(8):963-
Health status

Included for

systematic reviews not completed 
737 Fuchs, S. C.,Victora, C. G. Risk and prognostic factors for diarrheal disease in Brazilian infants: a special case-control design application. Cad Saude Publica. 2002;18(3):773-82.
Included for systematic reviews not completed

Included for systematic reviews not completed

Included for systematic reviews not completed

Independent variable

Independent variable

Included for

systematic reviews not completed

Study design

Study design

Dependent variable

745 Gabriele, C.,Silva, L. M.,Arends, L. R.,Raat, H.,Moll, H. A.,Hofman, A.,Jaddoe, V. W., de Jongste, J. C. Early respiratory morbidity in a multicultural birth cohort: the Generation R Study. Eur J Epidemiol. 2012;27(6):453-62.

746 Gaffney, K. F.,Kitsantas, P.,Cheema, J. Clinical practice guidelines for feeding behaviors of the Infant Feeding Practices Study II. Worldviews Evid Based Nurs. 2012;9(4):234-42.

747 Galan-Gonzalez AF,Aznar-Martin T,Cabrera-Dominguez ME,Dominguez-Reyes A. Do breastfeeding and bottle feeding influence occlusal parameters?. Breastfeed Med. 2014;9:24-8.

748 Galán-Gónzalez, A. F.,Aznar-Martín, T.,Cabrera-Domínguez, M. E.,Domínguez-Reyes, A. Do breastfeeding and bottle feeding influence occlusal parameters?. Breastfeeding Medicine. 2014;9(1):24-28.

749 Gale, C. R.,Marriott, L. D.,Martyn, C. N.,Limond, J.,Inskip, H. M.,Godfrey, K. M.,Law, C. M.,Cooper, C.,West, C.,Robinson, S. M. Breastfeeding, the use of docosahexaenoic acid-fortified formulas in infancy and neuropsychological function in childhood. Arch Dis Child. 2010;95(3):174-9.

Included for

systematic reviews not completed

Included for systematic reviews not completed

750 Gale, C. R.,Martyn, C. N. Breastfeeding, dummy use, and adult intelligence. Lancet. 1996;347(9008):1072-5. 
751 Gale, C. R.,Martyn, C. N.,Marriott, L. D.,Limond, J.,Crozier, S.,Inskip, H. M.,Godfrey, K. M.,Law, C. M.,Cooper, C.,Robinson, S. M. Dietary patterns in infancy and cognitive and neuropsychological function in childhood. Journal of Child Psychology and Psychiatry and Allied Disciplines. 2009;50(7):816-823.

752 Gale, C.,Thomas, E. L.,Jeffries, S.,Durighel, G.,Logan, K. M.,Parkinson, J. R.,Uthaya, S.,Santhakumaran, S.,Bell, J. D.,Modi, N. Adiposity and hepatic lipid in healthy full-term, breastfed, and formula-fed human infants: a prospective short-term longitudinal cohort study. Am J Clin Nutr. 2014;99(5):1034-40

753 Galler, J. R.,Harrison, R. H.,Ramsey, F.,Forde, V.,Butler, S. C. Maternal depressive symptoms affect infant cognitive development in Barbados. J Child Psychol Psychiatry. 2000;41(6):747-57.

754 Galler, J. R.,Ramsey, F. C.,Harrison, R. H.,Brooks, R.,Weiskopf-Bock, S. Infant feeding practices in Barbados predict later growth. J Nutr. 1998;128(8):1328-35.

755 Galler, J. R.,Ramsey, F. C.,Harrison, R. H., Taylor, J.,Cumberbatch, G.,Forde, V. Postpartum maternal moods and infant size predict performance on a national high school entrance examination. J Child Psychol Psychiatry. 2004;45(6):1064-75. completed

756 Gallico R,Hokemeyer C. SIDS project offers delactation advice. NAACOG Newsl. 1987;14:4-5.

Study design

757 Garcia, M. V.,Azevedo, M. F.,Testa, J. R.,Luiz, C. B. The influence of the type of breastfeeding on middle ear conditions in infants. Braz J Otorhinolaryngol. 2012;78(1):8-14.

758 Garcia-Marcos, L.,Mallol, J.,Sole, D.,Brand, P. L. International study of wheezing in infants: risk factors in affluent and non-affluent countries during the first year of life. Pediatr Allergy Immunol. 2010;21(5):878-88.

759 Garcia-Marcos, L.,Mallol, J.,Sole, D.,Brand, P. L.,Sanchez-Bahillo, M.,Sanchez-Solis, M. Latitude modifies the effect size of factors related to recurrent wheeze in the first year of life. Respir Med. 2013;107(5):665-72.

Study design

Study design

Study design,

Dependent variable

760 Garden, F. L.,Marks, G. B.,Simpson, J. M.,Webb, K. L. Body mass index (BMI) trajectories from birth to 11.5 years: relation to early life food intake. Nutrients. 2012;4(10):1382-98.

Included for

systematic reviews not completed

761 Garmendia, M. L.,Corvalan, C.,Araya, M.,Casanello, P.,Kusanovic, J. P.,Uauy, R. Effectiveness of a normative nutrition intervention (diet, physical activity and breastfeeding) on maternal nutrition and offspring growth: the Chilean maternal and infant nutrition cohort study (CHiMINCs). BMC Pregnancy Childbirth. 2015;15:175.

762 Garry, P. J.,Owen, G. M.,Hooper, E. M.,Gilbert, B. A. Iron absorption from human milk and formula with and without iron supplementation.

Study design, Independent variable

\section{Pediatr Res. 1981;15(5):822-8.}

Included for systematic reviews not completed

763 Garza, C. The INTERGROWTH-21st project and the multicenter growth reference study: enhanced opportunities for monitoring growth from early pregnancy to 5 years of age. Breastfeed Med. 2014;9(7):341-4. 
764 Garza, C.,Borghi, E.,Onyango, A. W.,de Onis, M. Parental height and child growth from birth to 2 years in the WHO Multicentre Growth Reference Study. Matern Child Nutr. 2013;9 Suppl 2:58-68.

Included for

systematic reviews not completed

Study design

Gathwala, G.,Narang, A. Breast is best. Indian J Pediatr. 1995;62(6):687-90

766 Geller-Bernstein, G.,Kenett, R.,Weisglass, L.,Tsur, S.,Lahav, M.,Levin, S. Atopic babies with wheezy bronchitis. Follow-up study relating prognosis to sequential IgE values, type of early infant feeding, exposure to parental smoking and incidence of lower respiratory tract infections. Allergy. 1987;42(2):85-91.

767 Gerrard, J. W. Allergies in breastfed babies to foods ingested by the mother (review). Clin Rev Allergy. 1984;2(2):143-9.

768 Gerrard, J. W.,Shenassa, M. Food allergy: two common types as seen in breast and formula fed babies. Ann Allergy. 1983;50(6):375-9.

769 Gessner, B. D.,Ussery, X. T.,Parkinson, A. J.,Breiman, R. F. Risk factors for invasive disease caused by Streptococcus pneumoniae among Alaska native children younger than two years of age. Pediatr Infect Dis J. 1995;14(2):123-8.

770 Ghosh, S.,Sengupta, P. G.,Mondal, S. K.,Banu, M. K.,Gupta, D. N.,Sircar, B. K. Risk behavioural practices of rural mothers as determinants of childhood diarrhoea. J Commun Dis. 1997;29(1):7-14

771 Ghys, A.,Bakker, E.,Hornstra, G.,van den Hout, M. Red blood cell and plasma phospholipid arachidonic and docosahexaenoic acid levels at birth Study design and cognitive development at 4 years of age. Early Hum Dev. 2002;69(1-2):83-90.

772 Gianino, P.,Mastretta, E.,Longo, P.,Laccisaglia, A.,Sartore, M.,Russo, R.,Mazzaccara, A. Incidence of nosocomial rotavirus infections, symptomatic and asymptomatic, in breast-fed and non-breast-fed infants. Journal of Hospital Infection. 2002;50(1):13-17.

773 Gianni, M. L.,Roggero, P.,Baudry, C.,Ligneul, A.,Morniroli, D.,Garbarino, F.,le Ruyet, P.,Mosca, F. The influence of a formula supplemented with dairy lipids and plant oils on the erythrocyte membrane omega-3 fatty acid profile in healthy full-term infants: a double-blind randomized controlled trial. BMC Pediatr. 2012;12:164.

774 Gianni, M. L.,Roggero, P.,Morlacchi, L.,Garavaglia, E.,Piemontese, P.,Mosca, F. Formula-fed infants have significantly higher fat-free mass content in their bodies than breastfed babies. Acta Paediatr. 2014;103(7):e277-81.

775 Gibbs, B. G.,Forste, R. Breastfeeding, parenting, and early cognitive development. J Pediatr. 2014;164(3):487-93

776 Gibbs, B. G.,Forste, R. Socioeconomic status, infant feeding practices and early childhood obesity. Pediatr Obes. 2014;9(2):135-46.

777 Gibson-Davis, C. M.,Brooks-Gunn, J. Breastfeeding and verbal ability of 3-year-olds in a multicity sample. Pediatrics. 2006;118(5):e1444-51.
Study design

Study design

Dependent variable

Group size

Country

Study design

Independent variable

Included for systematic reviews not completed

Included for systematic reviews not completed

Included for systematic reviews not completed

Included for

systematic reviews not completed 
779 Gilbert, R. E.,Wigfield, R. E.,Fleming, P. J.,Berry, P. J.,Rudd, P. T. Bottle feeding and the sudden infant death syndrome. BMJ.

Included for 1995;310(6972):88-90

781 Gillman, M. W.,Rifas-Shiman, S. L.,Berkey, C. S.,Frazier, A. L.,Rockett, H. R.,Camargo, C. A., Jr.,Field, A. E.,Colditz, G. A. Breast-feeding and overweight in adolescence: within-family analysis [corrected]. Epidemiology. 2006;17(1):112-4.

Included for

systematic reviews not completed

782 Gillman, M. W.,Rifas-Shiman, S. L.,Camargo, C. A., Jr.,Berkey, C. S.,Frazier, A. L.,Rockett, H. R.,Field, A. E.,Colditz, G. A. Risk of overweight among adolescents who were breastfed as infants. JAMA. 2001;285(19):2461-7.

783 Gillman, M. W.,Rifas-Shiman, S. L.,Kleinman, K.,Oken, E.,Rich-Edwards, J. W.,Taveras, E. M. Developmental origins of childhood overweight: potential public health impact. Obesity (Silver Spring). 2008;16(7):1651-6.

Included for

systematic reviews not completed

784 Gimenez-Sanchez, F.,Delgado-Rubio, A.,Martinon-Torres, F.,Bernaola-Iturbe, E. Multicenter prospective study analysing the role of rotavirus on acute gastroenteritis in Spain. Acta Paediatr. 2010;99(5):738-42.

Study design, Health status

785 Giovannini, M.,Agostoni, C.,Fiocchi, A.,Bellu, R.,Trojan, S.,Riva, E. Antigen-reduced infant formulas versus human milk: growth and metabolic

Group size parameters in the first 6 months of life. J Am Coll Nutr. 1994;13(4):357-63.

786 Giovannini, M.,Verduci, E.,Zuccotti, G.,Biasucci, G.,Podesta, A.,Rottoli, A.,Gregori, D.,Ballali, S.,Banderali, G.,Riva, E.,Ghisleni, D.,Pogliani, L.,Cicero, C.,Tonella, M.,Frugnoli, I. Safety of a formula supplemented with galacto-oligosaccharides in term infants. International journal of probiotics \& prebiotics. 2013;8(2-3):67-74.

787 Giovannini, M.,Verduci, E.,Zuccotti, G.,Biasucci, G.,Podesta, A.,Rottoli, A.,Gregori, D.,Ballali, S.,Soldi, S.,Banderali, G.,Ghisleni, D.,Riva, E. Prebiotic effect of a formula supplemented with galacto-oligosaccharides in term infants: A randomized multicenter trial. Annals of nutrition \& metabolism. 2013;63:1667.

788 Gishti, O.,Jaddoe, V. W.,Duijts, L.,Franco, O. H.,Hofman, A.,Ikram, M. K.,Gaillard, R. Influence of breastfeeding on retinal vessel calibers in school-age children. The Generation R Study. Eur J Clin Nutr. 2015.

789 Giugliano, L. G.,Meyer, C. J.,Arantes, L. C.,Ribeiro, S. T.,Giugliano, R. Mannose-resistant haemagglutination (MRHA) and haemolysin (Hly) production of strains of Escherichia coli isolated from children with diarrhoea: effect of breastfeeding. J Trop Pediatr. 1993;39(3):183-7.

Included for systematic reviews not completed

\section{Study design}

Dependent variable

Study design, Health status

790 Giwercman, C.,Halkjaer, L. B.,Jensen, S. M.,Bonnelykke, K.,Lauritzen, L.,Bisgaard, H. Increased risk of eczema but reduced risk of early wheezy disorder from exclusive breast-feeding in high-risk infants. J Allergy Clin Immunol. 2010;125(4):866-71.

791 Glatthaar, C.,Whittall, D. E.,Welborn, T. A.,Gibson, M. J.,Brooks, B. H.,Ryan, M. M.,Byrne, G. C. Diabetes in Western Australian children descriptive epidemiology. Med J Aust. 1988;148(3):117-23.
Independent variable

Independent variable 
792 Gliddon, M. L.,Sutton, G. Prediction of 8-month MEE from neonatal risk factors and test results in SCBU and full-term babies. British Journal of

793 Glueck, C. J.,Salehi, M.,Sieve, L.,Wang, P. Growth, motor, and social development in breast- and formula-fed infants of metformin-treated women with polycystic ovary syndrome. J Pediatr. 2006;148(5):628-632. Audiology. 2001;35(1):77-85.

Non-human, Health status

Included for systematic reviews not completed

Included for systematic reviews not completed

Health status

795 Goldfield, G. S.,Paluch, R.,Keniray, K.,Hadjiyannakis, S.,Lumb, A. B.,Adamo, K. Effects of breastfeeding on weight changes in family-based pediatric obesity treatment. J Dev Behav Pediatr. 2006;27(2):93-7.

796 Golding, J.,Rogers, I. S.,Emmett, P. M. Breast feeding: benefits and hazards. Methodology and summary of results. Early Hum Dev. 1997;49 Suppl:S1-6.

797 Gomez-Sanchiz, M.,Canete, R.,Rodero, I.,Baeza, J. E.,Avila, O. Influence of breast-feeding on mental and psychomotor development. Clin Pediatr (Phila). 2003;42(1):35-42.

798 Gomez-Sanchiz, M.,Canete, R.,Rodero, I.,Baeza, J. E.,Gonzalez, J. A. Influence of breast-feeding and parental intelligence on cognitive development in the 24-month-old child. Clin Pediatr (Phila). 2004;43(8):753-61.

799 Gong, Y. H.,Ji, C. Y.,Zheng, X. X.,Shan, J. P.,Hou, R. Correlation of 4-month infant feeding modes with their growth and iron status in Beijing Chin Med J (Engl). 2008;121(5):392-8.

800 Gonzalez-Casanova, I.,Stein, A.,Hao, W.,Feregrino, R.,Romieu, I.,Barraza-Villarreal, A.,Rivera, J.,Martorell, R.,Ramakrishnan, U. Height and $\mathrm{BMI}$ at five years of age following prenatal supplementation with docosahexaenoic acid in Mexico. FASEB journal. 2014;28(1 suppl. 1).

801 Gopalan, S.,Puri, R. K. Breast feeding and infant growth. Indian Pediatr. 1992;29(8):1079-86.

802 Gopinath, V. K.,Muda, W. A. Assessment of growth and feeding practices in children with cleft lip and palate. Southeast Asian J Trop Med Public Health. 2005;36(1):254-8

803 Gordon, M. Why breastfeeding is best for babies. Health Visit. 1995;68(5):203-4

Study design

Included for

systematic reviews not completed

Included for systematic reviews not completed

Independent variable

Peer review

Study design

Independent variable Dependent variable

Study design

Dependent variable

804 Gordon, R. R.,Noble, D. A.,Ward, A. M.,Allen, R. Immunoglobulin E and the eczema-asthma syndrome in early childhood. Lancet 1982;1(8263):72-4

805 Gore, C.,Custovic, A.,Tannock, G. W.,Munro, K.,Kerry, G.,Johnson, K.,Peterson, C.,Morris, J.,Chaloner, C.,Murray, C. S.,Woodcock, A. Treatment and secondary prevention effects of the probiotics Lactobacillus paracasei or Bifidobacterium lactis on early infant eczema: randomized controlled trial with follow-up until age 3 years. Clin Exp Allergy. 2012;42(1):112-22.
Health status 
806 Gore, C.,Munro, K.,Lay, C.,Bibiloni, R.,Morris, J.,Woodcock, A.,Custovic, A., Tannock, G. W. Bifidobacterium pseudocatenulatum is associated with atopic eczema: a nested case-control study investigating the fecal microbiota of infants. J Allergy Clin Immunol. 2008;121(1):135-40.

807 Gore, N.,Emerson, E.,Brady, S. Rates of breastfeeding and exposure to socio-economic adversity amongst children with intellectual disability. Res Dev Disabil. 2015;39:12-9.

Included for systematic reviews not completed

808 Gormally, S. M.,Matthews, T. G. Contemporary risk factors for sudden infant death in an Irish population--a case control study. Ir J Med Sci. 1992;161(5):131-4.

Included for

systematic reviews not completed

809 Gracey, M. Maternal health, breast-feeding and infant nutrition in Australian aborigines. Acta Paediatr Jpn. 1989;31(4):377-80.

Study design

810 Grainger, M. Breastfeeding can reduce infant infections and health care costs. Ala Nurse. 2006;33(3):23.

Study design

811 Graves, J.,Grandhe, S.,Weinfurtner, K.,Krupp, L.,Belman, A.,Chitnis, T.,Ness, J.,Weinstock-Guttman, B.,Gorman, M.,Patterson, M.,Rodriguez, M.,Lotze, T.,Aaen, G.,Mowry, E. M.,Rose, J. W.,Simmons, T.,Casper, T. C.,James, J.,Waubant, E. Protective environmental factors for neuromyelitis optica. Neurology. 2014;83(21):1923-9.

812 Greasley, V. Breast feeding. Nursing (Lond). 1986;3(2):63-70.

Study design

813 Green, Ken. UC Denver Study: Breastfeeding Can Prevent Diabetes-Related Childhood Obesity. Inside Childbirth Education. 2012:10-10 1p.

Study design

814 Greene, L. C.,Lucas, A.,Livingstone, M. B.,Harland, P. S.,Baker, B. A. Relationship between early diet and subsequent cognitive performance during adolescence. Biochem Soc Trans. 1995;23(2):376S.

Included for systematic reviews not completed

815 Greer MH,Tendan SL. Early childhood dental caries in Hawai'i. Hawaii Dent J. 1998;29:10, 14.

Study design

816 Grguric, J.,Wen, R. A.,Kylberg, E.,Ashmore, S.,Macenroe, T. International perspectives on the Baby-Friendly Initiative. J Hum Lact. 2012;28(3):281-4.

817 Grice, A. C.,McGlashan, N. D. Obstetric factors in 171 sudden infant deaths in Tasmania, 1970--1976. Med J Aust. 1981;1(1):26-31.

Included for systematic reviews not completed

818 Griffiths, L. J.,Hawkins, S. S.,Cole, T. J.,Dezateux, C. Risk factors for rapid weight gain in preschool children: Findings from a UK-wide prospective study. International Journal of Obesity. 2010;34(4):624-632.

Included for systematic reviews not completed

819 Griffiths, L. J.,Smeeth, L.,Hawkins, S. S.,Cole, T. J.,Dezateux, C. Effects of infant feeding practice on weight gain from birth to 3 years. Arch Dis Child. 2009;94(8):577-82. 
821 Groen-Blokhuis, M. M.,Franic, S.,van Beijsterveldt, C. E.,de Geus, E.,Bartels, M.,Davies, G. E.,Ehli, E. A.,Xiao, X.,,Scheet, P. A.,Althoff,

Included for R.,Hudziak, J. J.,Middeldorp, C. M.,Boomsma, D. I. A prospective study of the effects of breastfeeding and FADS2 polymorphisms on cognition and hyperactivity/attention problems. Am J Med Genet B Neuropsychiatr Genet. 2013;162B(5):457-65.

systematic reviews not completed

822 Groenwold, R. H.,Tilling, K.,Moons, K. G.,Hoes, A. W.,van der Ent, C. K.,Kramer, M. S.,Martin, R. M.,Sterne, J. A. Breast-feeding and health Independent variable consequences in early childhood: is there an impact of time-dependent confounding?. Ann Nutr Metab. 2014;65(2-3):139-48.

823 Grossman, X.,Chaudhuri, J. H.,Feldman-Winter, L.,Merewood, A. Neonatal weight loss at a US Baby-Friendly Hospital. J Acad Nutr Diet. 2012;112(3):410-3

824 Grube, M. M.,von der Lippe, E.,Schlaud, M.,Brettschneider, A. K. Does breastfeeding help to reduce the risk of childhood overweight and obesity? A propensity score analysis of data from the KiGGS study. PLoS One. 2015;10(3):e0122534.

825 Gruber, C.,van Stuijvenberg, M.,Mosca, F.,Moro, G.,Chirico, G.,Braegger, C. P.,Riedler, J.,Boehm, G.,Wahn, U. Reduced occurrence of early atopic dermatitis because of immunoactive prebiotics among low-atopy-risk infants. J Allergy Clin Immunol. 2010;126(4):791-7.

826 Gruber, M.,Marshall, J. R.,Zielezny, M.,Lance, P. A case-control study to examine the influence of maternal perinatal behaviors on the incidence Study design of Crohn's disease. Gastroenterol Nurs. 1996;19(2):53-9.

827 Grummer-Strawn, L. M.,Li, R.,Perrine, C. G.,Scanlon, K. S.,Fein, S. B. Infant feeding and long-term outcomes: results from the year 6 follow-up of children in the Infant Feeding Practices Study II. Pediatrics. 2014;134 Suppl 1:S1-3.

828 Grummer-Strawn, L. M.,Mei, Z. Does breastfeeding protect against pediatric overweight? Analysis of longitudinal data from the Centers for Disease Control and Prevention Pediatric Nutrition Surveillance System. Pediatrics. 2004;113(2):e81-6.

\section{Group size}

Study design

ndependent variable

Study design

Study design systematic reviews not completed

829 Gruskay, F. L. Comparison of breast, cow, and soy feedings in the prevention of onset of allergic disease: a 15-year prospective study. Clin Pediatr (Phila). 1982;21(8):486-91.

830 Gruszfeld, D.,Weber, M.,Nowakowska-Rysz, M.,Janas, R.,Kozlik-Feldmann, R., Xhonneux, A.,Carlier, C., Riva, E.,Verduci, E.,Closa-Monasterolo, R.,Escribano, J.,Dobrzanska, A.,Koletzko, B. Protein intake in infancy and carotid intima media thickness at 5 years--a secondary analysis from a randomized trial. Ann Nutr Metab. 2015;66(1):51-9.

831 Gubbels, J. S., Thijs, C., Stafleu, A.,van Buuren, S., Kremers, S. P. Association of breast-feeding and feeding on demand with child weight status up to 4 years. Int J Pediatr Obes. 2011;6(2-2):e515-22.

832 Gudino, S.,Rojas, N.,Castro, C.,Rodriguez, M.,Vega, M.,Lopez, L. M. Colonization of mutans streptococci in Costa Rican children from a highrisk population. J Dent Child (Chic). 2007;74(1):36-40.

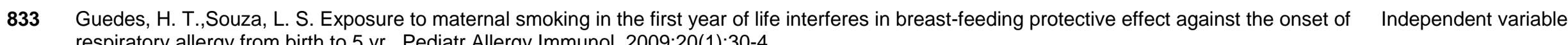
respiratory allergy from birth to $5 \mathrm{yr}$. Pediatr Allergy Immunol. 2009;20(1):30-4. 
834 Guerrero, M. L.,Moreno-Espinosa, S.,Tuz-Dzib, F.,Solis-Albino, J.,Ortega-Gallegos, H.,Ruiz-Palacios, G. M. Breastfeeding and natural colonization with Lactobacillus spp as protection against rotavirus-associated diarrhea. Adv Exp Med Biol. 2004;554:451-5. 835 Guibas, G. V.,Xepapadaki, P.,Moschonis, G.,Douladiris, N.,Filippou, A.,Tsirigoti, L.,Manios, Y.,Papadopoulos, N. G. Breastfeeding and wheeze
prevalence in pre-schoolers and pre-adolescents: the Genesis and Healthy Growth studies. Pediatr Allergy Immunol. 2013;24(8):772-81.

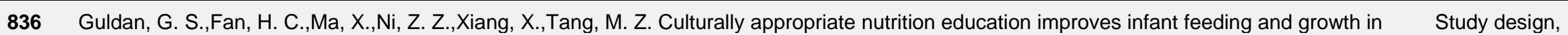
rural Sichuan, China. J Nutr. 2000;130(5):1204-11.

837 Gulick EE. The effects of breast-feeding on toddler health. Pediatr Nurs. 1986;12:51-4.

Dependent variable

838 Gulick, E. E. Infant health and breast-feeding. Pediatr Nurs. 1983;9(5):359-62, 389.

Dependent variable

Study design

839 Gunderson, E. P. Breastfeeding after gestational diabetes pregnancy: subsequent obesity and type 2 diabetes in women and their offspring. Diabetes Care. 2007;30 Suppl 2:S161-8.

840 Gunderson, E. P.,Hurston, S. R.,Dewey, K. G.,Faith, M. S.,Charvat-Aguilar, N.,Khoury, V. C.,Nguyen, V. T.,Quesenberry, C. P., Jr. The study of

Study design women, infant feeding and type 2 diabetes after GDM pregnancy and growth of their offspring (SWIFT Offspring study): prospective design, methodology and baseline characteristics. BMC Pregnancy Childbirth. 2015;15:150.

841 Gungor, D. E.,Paul, I. M.,Birch, L. L.,Bartok, C. J. Risky vs rapid growth in infancy: refining pediatric screening for childhood overweight. Arch Pediatr Adolesc Med. 2010;164(12):1091-7.

842 Gunnarsdottir, I.,Aspelund, T.,Birgisdottir, B. E.,Benediktsson, R.,Gudnason, V.,Thorsdottir, I. Infant feeding patterns and midlife erythrocyte sedimentation rate. Acta Paediatr. 2007;96(6):852-6.

843 Gunnarsdottir, I.,Schack-Nielsen, L.,Michaelsen, K. F.,Sorensen, T. I.,Thorsdottir, I. Infant weight gain, duration of exclusive breast-feeding and childhood BMI - two similar follow-up cohorts. Public Health Nutr. 2010;13(2):201-7.

844 Gunther, A. L.,Walz, H.,Kroke, A.,Wudy, S. A.,Riedel, C.,von Kries, R.,Joslowski, G.,Remer, T.,Cheng, G.,Buyken, A. E. Breastfeeding and its prospective association with components of the GH-IGF-Axis, insulin resistance and body adiposity measures in young adulthood--insights from linear and quantile regression analysis. PLoS One. 2013;8(11):e79436.

845 Guo, A. Y.,Stevens, B. W.,Wilson, R. G.,Russell, C. N.,Cohen, M. A., Sturgeon, H. C., Thornton, A.,Giallourakis, C., Khalili, H.,Nguyen, D. D.,Sauk, J.,Yajnik, V.,Xavier, R. J.,Ananthakrishnan, A. N. Early life environment and natural history of inflammatory bowel diseases. BMC Gastroenterol. 2014;14:216.

846 Gurkan, F.,Davutog Lu, M.,Bilici, M.,Sincar, N.,Haspolat, K. Pulmonary functions in atopic and nonatopic asthmatic children. Allergol Immunopathol (Madr). 2002;30(2):70-3.

Included for

systematic reviews not completed

Independent variable

Included for

systematic reviews not completed

Independent variable

Study design

Dependent variable

Study design, Health status

847 Gurkan, F.,Davutoglu, M.,Bilici, M.,Dagli, A.,Haspolat, K. Asthmatic children and risk factors at a province in the southeast of Turkey. Allergol Immunopathol (Madr). 2002;30(1):25-9.
Study design 
848 Gurnida, D. A.,Rowan, A. M.,Idjradinata, P.,Muchtadi, D.,Sekarwana, N. Association of complex lipids containing gangliosides with cognitive development of 6-month-old infants. Early Hum Dev. 2012;88(8):595-601.

849 Gurwith, M.,Wenman, W.,Gurwith, D.,Brunton, J.,Feltham, S.,Greenberg, H. Diarrhea among infants and young children in Canada: a longitudinal study in three northern communities. J Infect Dis. 1983;147(4):685-92.

850 Gurwith, M.,Wenman, W.,Hinde, D.,Feltham, S.,Greenberg, H. A prospective study of rotavirus infection in infants and young children. J Infect Dis. $1981 ; 144(3): 218-24$

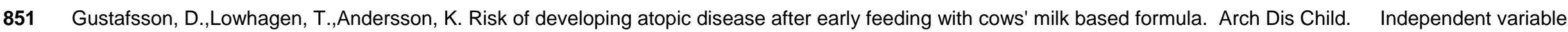
1992;67(8):1008-10.

852 Gustafsson, P. A.,Duchen, K.,Birberg, U.,Karlsson, T. Breastfeeding, very long polyunsaturated fatty acids (PUFA) and IQ at $61 / 2$ years of age. Acta Paediatr. 2004;93(10):1280-7.

Included for systematic reviews not completed

853 Guxens, M.,Aguilera, I.,Ballester, F.,Estarlich, M.,Fernandez-Somoano, A.,Lertxundi, A.,Lertxundi, N.,Mendez, M. A.,Tardon, A.,Vrijheid, M.,Sunyer, J. Prenatal exposure to residential air pollution and infant mental development: modulation by antioxidants and detoxification factors. Environ Health Perspect. 2012;120(1):144-9.

Included for systematic reviews not completed

854 Guxens, M.,Mendez, M. A.,Molto-Puigmarti, C.,Julvez, J.,Garcia-Esteban, R.,Forns, J.,Ferrer, M.,Vrijheid, M.,Lopez-Sabater, M. C.,Sunyer, J. Breastfeeding, long-chain polyunsaturated fatty acids in colostrum, and infant mental development. Pediatrics. 2011;128(4):e880-9.

Included for

systematic reviews not completed

855 Habibzadeh, H.,Jafarizadeh, H.,Didarloo, A. Determinants of failure to thrive (FTT) among infants aged 6-24 months: a case-control study. J Prev Med Hyg. 2015;56(4):E180-6.

Included for

systematic reviews not completed

856 Habicht, J. P.,DaVanzo, J.,Butz, W. P. Does breastfeeding really save lives, or are apparent benefits due to biases?. Am J Epidemiol. $1986 ; 123(2): 279-90$

Study design

857 Habicht, J. P.,DaVanzo, J.,Butz, W. P. Mother's milk and sewage: their interactive effects on infant mortality. Pediatrics. 1988;81(3):456-61.

Study design

858 Hackney, A. R. Breast feeding. Am J Nurs. 1990;90(12):70.

859 Haddad, M. B.,Porucznik, C. A.,Joyce, K. E.,De, A. K.,Pavia, A. T.,Rolfs, R. T.,Byington, C. L. Risk factors for pediatric invasive pneumococcal disease in the Intermountain West, 1996-2002. Ann Epidemiol. 2008;18(2):139-46.

860 Haider, S. J.,Chang, L. V.,Bolton, T. A.,Gold, J. G.,Olson, B. H. An evaluation of the effects of a breastfeeding support program on health outcomes. Health Serv Res. 2014;49(6):2017-34.

Study design

Independent variable

Independent variable Dependent variable

861 Haines, M. R.,Kintner, H. J. "Can breast feeding help you in later life? Evidence from German military heights in the early 20 th century". Econ Hum Biol. 2008;6(3):420-30.

Study design, Independent variable

862 Hakansson, A.,Carlsson, B. Maternal cigarette smoking, breast-feeding, and respiratory tract infections in infancy. A population-based cohort Study design, study. Scand J Prim Health Care. 1992;10(1):60-5. 
864 Halken, S. What causes allergy and asthma? The role of dietary factors. Pediatr Pulmonol Suppl. 2004;26:223-4.

Study design

865 Halken, S.,Hansen, K. S.,Jacobsen, H. P.,Estmann, A.,Faelling, A. E.,Hansen, L. G.,Kier, S. R., Lassen, K.,Lintrup, M.,Mortensen, S.,Ibsen, K. K.,Osterballe, O.,Host, A. Comparison of a partially hydrolyzed infant formula with two extensively hydrolyzed formulas for allergy prevention: a prospective, randomized study. Pediatr Allergy Immunol. 2000;11(3):149-61.

866 Halken, S.,Host, A.,Hansen, L. G.,Osterballe, O. Effect of an allergy prevention programme on incidence of atopic symptoms in infancy. A prospective study of 159 "high-risk" infants. Allergy. 1992;47(5):545-53.

867 Halken, S.,Host, A.,Hansen, L. G.,Osterballe, O. Preventive effect of feeding high-risk infants a casein hydrolysate formula or an ultrafiltrated whey hydrolysate formula. A prospective, randomized, comparative clinical study. Pediatr Allergy Immunol. 1993;4(4):173-81.

868 Halken, S.,Host, A.,Husby, S.,Hansen, L. G.,Osterballe, O.,Nyboe, J. Recurrent wheezing in relation to environmental risk factors in infancy. A prospective study of 276 infants. Allergy. 1991;46(7):507-14.

869 Hallonsten, A. L.,Wendt, L. K.,Mejare, I.,Birkhed, D.,Hakansson, C.,Lindvall, A. M.,Edwardsson, S.,Koch, G. Dental caries and prolonged breast- $\quad$ Study design feeding in 18-month-old Swedish children. Int J Paediatr Dent. 1995;5(3):149-55.

870 Hambraeus, L. The significance of mother's milk and breast-feeding for development and later life. Bibl Nutr Dieta. 1982(31):1-16.

Study design

871 Hamburger, R. N.,Heller, S.,Mellon, M. H.,O'Connor, R. D.,Zeiger, R. S. Current status of the clinical and immunologic consequences of a prototype allergic disease prevention program. Ann Allergy. 1983;51(2 Pt 2):281-90.

872 Hamilton, J. J.,Synnes, A.,Innis, S. M. Plasma cholesterol and lathosterol levels in term infants in the early neonatal period. Pediatr Res. 1992;31(4 Pt 1):396-400.

873 Hamilton, J. R. Viral diarrhea. Pediatr Ann. 1985;14(1):25-8.

Study design, Independent variable

Group size

Dependent variable

Study design Independent variable

Group size

Study design

Study design

874 Han, D. H.,Ahn, J. C.,Mun, S. J.,Park, S. K.,Oh, S. Y.,Rhee, C. S. Novel risk factors for allergic rhinitis in Korean elementary school children ARCO-kids phase II in a community. Allergy, Asthma and Immunology Research. 2015;7(3):234-240.

875 Han, D. Y.,Fraser, A. G.,Dryland, P.,Ferguson, L. R. Environmental factors in the development of chronic inflammation: a case-control study on risk factors for Crohn's disease within New Zealand. Mutat Res. 2010;690(1-2):116-22.

876 Han, Y. S.,Park, H. Y.,Ahn, K. M.,Lee, J. S.,Choi, H. M.,Lee, S. I. Short-term effect of partially hydrolyzed formula on the prevention of development of atopic dermatitis in infants at high risk. J Korean Med Sci. 2003;18(4):547-51.

877 Han, Y.,Chung, S. J.,Kim, J.,Ahn, K.,Lee, S. I. High sensitization rate to food allergens in breastfed infants with atopic dermatitis. Ann Allergy Asthma Immunol. 2009;103(4):332-6.

878 Hancox, R. J.,Stewart, A. W.,Braithwaite, I.,Beasley, R.,Murphy, R.,Mitchell, E. A. Association between breastfeeding and body mass index at age 6-7 years in an international survey. Pediatr Obes. 2015;10(4):283-7.
Study design

Group size

Study design

Study design
Dependent variable 
879 Hanicar, B.,Mandic, Z.,Pavic, R. Exclusive breastfeeding and growth in Croatian infants--comparison to the WHO child growth standards and to the NCHS growth references. Coll Antropol. 2009;33(3):735-41.
Included for systematic reviews not completed

Included for systematic reviews not completed

Study design

Study design

Country

Study design

Country

Independent variable

Dependent variable

Study design

Study design Dependent variable

Group size

Group size

Study design

Group size

Group size

$893 \begin{aligned} & \text { Harsten, G.,Prellner, K.,Heldrup, J.,Kalm, O., } \\ & \text { of life. Acta Otolaryngol. 1989;107(1-2):111-9. }\end{aligned}$ 
895 Hartley, A. L.,Birch, J. M.,McKinney, P. A.,Blair, V.,Teare, M. D.,Carrette, J.,Mann, J. R.,Stiller, C. A.,Draper, G. J.,Johnston, H. E., et al.,. The Inter-Regional Epidemiological Study of Childhood Cancer (IRESCC): past medical history in children with cancer. J Epidemiol Community Health. 1988;42(3):235-42.

Dependent variable

896 Harvey, N. C.,Robinson, S. M.,Crozier, S. R.,Marriott, L. D.,Gale, C. R.,Cole, Z. A.,Inskip, H. M.,Godfrey, K. M.,Cooper, C. Breast-feeding and adherence to infant feeding guidelines do not influence bone mass at age 4 years. Br J Nutr. 2009;102(6):915-20.

Haschke, F.,van't Hof, M. A. Euro-Growth references for breast-fed boys and girls: influence of breast-feeding and solids on growth until 36 months of age. Euro-Growth Study Group. J Pediatr Gastroenterol Nutr. 2000;31 Suppl 1:S60-71.

898 Haschke, F.,Vanura, H.,Male, C.,Owen, G.,Pietschnig, B.,Schuster, E.,Krobath, E.,Huemer, C. Iron nutrition and growth of breast- and formulafed infants during the first 9 months of life. J Pediatr Gastroenterol Nutr. 1993;16(2):151-6.

899 Haschke, F.,Ziegler, E. E.,Grathwohl, D. Fast growth of infants of overweight mothers: Can it be slowed down?. Annals of Nutrition and Metabolism. 2014;64:19-24.

900 Hasselbalch, H.,Jeppesen, D. L.,Ersboll, A. K.,Engelmann, M. D.,Nielsen, M. B. Thymus size evaluated by sonography. A longitudinal study on infants during the first year of life. Acta Radiol. 1997;38(2):222-7.

901 Hassiotou, F.,Geddes, D. T. Programming of appetite control during breastfeeding as a preventative strategy against the obesity epidemic. J Study design Hum Lact. 2014;30(2):136-42.

902 Hatano, S.,Aihara, K.,Nishi, Y.,Usui, T. Trace elements (copper, zinc, manganese, and selenium) in plasma and erythrocytes in relation to dietary intake during infancy. J Pediatr Gastroenterol Nutr. 1985;4(1):87-92.

903 Hathcock, A.,Krause, K.,Viera, A. J.,Fuemmeler, B. F.,Lovelady, C., Ostbye, T. Satiety responsiveness and the relationship between breastfeeding and weight status of toddlers of overweight and obese women. Matern Child Health J. 2014;18(4):1023-30.

Included for systematic reviews not completed

Independent variable

Group size

Independent variable

Group size

Group size

Study design

904 Hattab, F. N.,Al-Omari, M. A.,Angmar-Mansson, B.,Daoud, N. The prevalence of nursing caries in one-to-four-year-old children in Jordan. ASDC Study design J Dent Child. 1999;66(1):53-8.

905 Hauck, F. R.,Herman, S. M.,Donovan, M.,Iyasu, S.,Merrick Moore, C.,Donoghue, E.,Kirschner, R. H.,Willinger, M. Sleep environment and the risk of sudden infant death syndrome in an urban population: the Chicago Infant Mortality Study. Pediatrics. 2003;111(5 Pt 2):1207-14.

906 Hawkins, S. S.,Cole, T. J.,Law, C. An ecological systems approach to examining risk factors for early childhood overweight: findings from the UK Millennium Cohort Study. J Epidemiol Community Health. 2009;63(2):147-55.

907 Hawley, N. L.,Johnson, W.,Nu'usolia, O.,McGarvey, S. T. The contribution of feeding mode to obesogenic growth trajectories in American Samoan infants. Pediatr Obes. 2014;9(1):e1-e13.
Included for

systematic reviews not completed

Included for systematic reviews not completed

Independent variable 

(International Edition). 2004;328(7435):349-349 1p.

909 Hay, D. F.,Pawlby, S.,Sharp, D.,Asten, P.,Mills, A.,Kumar, R. Intellectual problems shown by 11-year-old children whose mothers had postnata depression. J Child Psychol Psychiatry. 2001;42(7):871-89.

Included for systematic reviews not completed

910 Hayatbakhsh, M. R.,O'Callaghan M, J.,Bor, W.,Williams, G. M.,Najman, J. M. Association of breastfeeding and adolescents' psychopathology: A large prospective study. Breastfeeding Medicine. 2012;7(6):480-486.

Included for systematic reviews not completed

911 Hayes, K. C.,Pronczuk, A.,Wood, R. A.,Guy, D. G. Modulation of infant formula fat profile alters the low-density lipoprotein/high-density lipoprotein ratio and plasma fatty acid distribution relative to those with breast-feeding. J Pediatr. 1992;120(4 Pt 2):S109-16.

Group size

912 Hayosh, O.,Mandel, D.,Mimouni, F. B.,Lahat, S.,Marom, R.,Lubetzky, R. Prolonged duration of breastfeeding does not affect lipid profile in adulthood. Breastfeed Med. 2015;10(4):218-21.

913 Hearst, Mary O.,Martin, Lauren,Rafdal, Brooke H.,Robinson, Ronel,McConnell, Scott R. Early childhood development and obesity risk-factors in a multi-ethnic, low-income community: Feasibility of the 'Five Hundred under Five' social determinants of health pilot study. Health Education Journal. 2013;72(2):203-215 13p

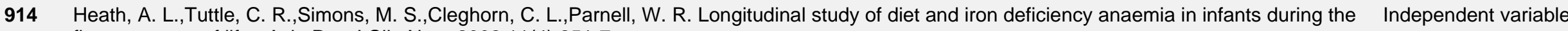
first two years of life. Asia Pac J Clin Nutr. 2002;11(4):251-7.

915 Hedstrom, M. Breastfeeding and Amningshjalpen in Sweden. J Trop Pediatr. 1982;28(3):113-5.

Study design

916 Hegde CV,Anand RK. Bowel pattern and weight gain in breastfed infants. Indian Pediatr. 1987;24:859-64

Country

917 Heikkila, K.,Kelly, Y.,Renfrew, M. J.,Sacker, A.,Quigley, M. A. Breastfeeding and educational achievement at age 5. Matern Child Nutr. 2014;10(1):92-101

Included for systematic reviews not completed

918 Heikkilä, K.,Sacker, A.,Kelly, Y.,Renfrew, M. J.,Quigley, M. A. 012 Breast feeding and behavioural development in children: findings from the Millennium Cohort Study. Journal of Epidemiology \& Community Health. 2010;64:A5-A5 1p.

\section{Peer review}

919 Heikkila, K.,Sacker, A.,Kelly, Y.,Renfrew, M. J.,Quigley, M. A. Breast feeding and child behaviour in the Millennium Cohort Study. Arch Dis Child. 2011;96(7):635-42.

Included for

systematic reviews not completed

920 Heine, W.,Lapsien, C. Influence of early breast milk and formula feeding on body weight in children born in Rostock since 1945. Bibl Nutr Dieta. 1982(31):17-8.

Study design, Independent variable

921 Heiner, D. C. Modern research relating to food allergy and its implications--introduction. Clin Rev Allergy. 1984;2(1):1-5.

Study design 
924 Heinig, M. J.,Nommsen, L. A.,Peerson, J. M.,Lonnerdal, B.,Dewey, K. G. Intake and growth of breast-fed and formula-fed infants in relation to the timing of introduction of complementary foods: the DARLING study. Davis Area Research on Lactation, Infant Nutrition and Growth. Acta Paediatr. 1993;82(12):999-1006.

925 Hemalatha, P.,Bhaskaram, P.,Kumar, P. A.,Khan, M. M.,Islam, M. A. Zinc status of breastfed and formula-fed infants of different gestational ages. J Trop Pediatr. 1997;43(1):52-4.

926 Henry, F. J.,Bartholomew, R. K. Epidemiology and transmission of rotavirus infections and diarrhoea in St. Lucia, West Indies. West Indian Med J. 1990;39(4):205-12.

927 Heppe, D. H. M.,Kiefte-De Jong, J. C.,Durmuş, B.,Moll, H. A.,Raat, H.,Hofman, A.,Jaddoe, V. W. V. Parental, fetal, and infant risk factors for preschool overweight: The Generation R Study. Pediatric Research. 2013;73(1):120-127.

928 Hepworth, S. J.,Law, G. R.,Lawlor, D. A.,McKinney, P. A. Early life patterns of common infection: a latent class analysis. Eur J Epidemiol. 2010;25(12):875-83.

929 Herba, C. M.,Roza, S.,Govaert, P.,Hofman, A.,Jaddoe, V.,Verhulst, F. C.,Tiemeier, H. Breastfeeding and early brain development: the Generation R study. Matern Child Nutr. 2013;9(3):332-49.

930 Heresi, G.,Pizarro, F.,Olivares, M.,Cayazzo, M.,Hertrampf, E.,Walter, T.,Murphy, J. R.,Stekel, A. Effect of supplementation with an iron-fortified milk on incidence of diarrhea and respiratory infection in urban-resident infants. Scand J Infect Dis. 1995;27(4):385-9.

931 Hernell, O.,Lonnerdal, B. Iron status of infants fed low-iron formula: no effect of added bovine lactoferrin or nucleotides. Am J Clin Nutr.

Independent variable 2002;76(4):858-64

932 Hernell, O.,Lonnerdal, B. Nutritional evaluation of protein hydrolysate formulas in healthy term infants: plasma amino acids, hematology, and trace elements. Am J Clin Nutr. 2003;78(2):296-301.

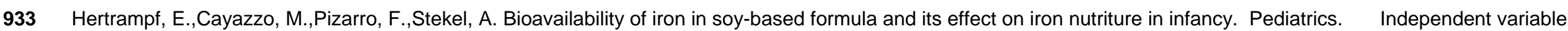
$1986 ; 78(4): 640-5$.

934 Hide DW,Guyer BM. Cows milk intolerance in Isle of Wight infants. Br J Clin Pract. 1983;37:285-7.

935 Hide, D. W. Aspects of nutrition: Isle of Wight infant feeding survey. Health Visit. 1980;53(2):43.

936 Hide, D. W. The clinical expression of allergy in breast-fed infants. Adv Exp Med Biol. 1991;310:475-80. 
939 Hide, D. W.,Matthews, S.,Matthews, L.,Stevens, M.,Ridout, S.,Twiselton, R.,Gant, C.,Arshad, S. H. Effect of allergen avoidance in infancy on Independent variable allergic manifestations at age two years. J Allergy Clin Immunol. 1994;93(5):842-6.

940 Hide, D. W.,Matthews, S.,Tariq, S.,Arshad, S. H. Allergen avoidance in infancy and allergy at 4 years of age. Allergy. 1996;51(2):89-93.

Independent variable

941

Higashi, A.,Ikeda, T.,Uehara, I.,Matsuda, I. Effect of low-content zinc and copper formula on infant nutrition. Eur J Pediatr. 1982;138(3):237-40.

Group size

942 Highet, A. R.,Berry, A. M.,Bettelheim, K. A.,Goldwater, P. N. Gut microbiome in sudden infant death syndrome (SIDS) differs from that in healthy comparison babies and offers an explanation for the risk factor of prone position. Int J Med Microbiol. 2014;304(5-6):735-41.

Independent variable Dependent variable

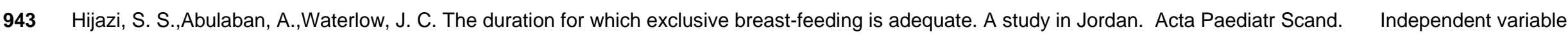
1989;78(1):23-8.

944 Hiley, C. M.,Morley, C. J. Risk factors for sudden infant death syndrome: further change in 1992-3. BMJ. 1996;312(7043):1397-8.

Study design

945

Hill, D. J.,Hosking, C. S. Preventing childhood allergy. Med J Aust. 1993;158(6):367-9.

Study design

946 Hillman, L. S. Bone mineral content in term infants fed human milk, cow milk-based formula, or soy-based formula. J Pediatr. 1988;113(1 Pt 2):208-12.

947 Hillman, L. S.,Chow, W.,Salmons, S. S.,Weaver, E.,Erickson, M.,Hansen, J. Vitamin D metabolism, mineral homeostasis, and bone mineralization in term infants fed human milk, cow milk-based formula, or soy-based formula. J Pediatr. 1988;112(6):864-74.

948 Hirota, T.,Nara, M.,Ohguri, M.,Manago, E.,Hirota, K. Effect of diet and lifestyle on bone mass in Asian young women. Am J Clin Nutr. 1992;55(6):1168-73.

949 Hitchcock, N. E.,Coy, J. F. The growth of healthy Australian infants in relation to infant feeding and social group. Med J Aust. 1989;150(6):306-8, 310-1.

systematic reviews not completed

950 Hitchcock, N. E.,Gracey, M.,Gilmour, A. I. The growth of breast fed and artificially fed infants from birth to twelve months. Acta Paediatr Scand. $1985 ; 74(2): 240-5$

Included for systematic reviews not completed

951 Hitchcock, N. E.,Gracey, M.,Owles, E. N. Growth of healthy breast-fed infants in the first six months. Lancet. 1981;2(8237):64-5.

Study design, Independent variable 
954 Hoffhines, H.,Whaley, K. D.,Blackett, P. R.,Palumbo, K.,Campbell-Sternloff, D.,Glore, S.,Lee, E. T. Early childhood nutrition in an American Indian community: educational strategy for obesity prevention. J Okla State Med Assoc. 2014;107(2):55-9.

955 Hoffmans, M. D.,Obermann-de Boer, G. L.,Florack, E. I.,van Kampen-Donker, M.,Kromhout, D. Determinants of growth during early infancy. Hum Biol. 1988;60(2):237-49.

956 Hofvander Y,Hillervik C. Breast-feeding in Swedish hospitals. World Health Forum. 1995;16:95-9.

Included for systematic reviews not completed

Study design Dependent variable

Independent variable

957 Hogendorf, A.,Stanczyk-Przyluska, A.,Sieniwicz-Luzenczyk, K.,Wiszniewska, M.,Arendarczyk, J.,Banasik, M.,Fendler, W.,Kowalski, M.,Zeman, $\mathrm{K}$. Is there any association between secretory IgA and lactoferrin concentration in mature human milk and food allergy in breastfed children. Med Wieku Rozwoj. 2013;17(1):47-52

958 Hokama, T. A study of the hemoglobin levels in breast-fed infants in one village of Okinawa prefecture. Acta Paediatr Jpn. 1993;35(2):138-40.

Group size

Hokama, T. Levels of serum ferritin and total body iron among infants with different feeding regimens. Acta Paediatr Jpn. 1993;35(4):298-301.

Study design

960 Hokama, T.,Sakamoto, R., Yara, A.,Asato, Y.,Takamine, F.,Itokazu, K. Incidence of Haemophilus influenzae in the throats of healthy infants with Study design different feeding methods. Pediatr Int. 1999;41(3):277-80.

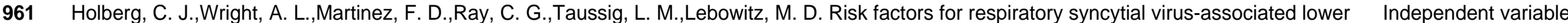
respiratory illnesses in the first year of life. Am J Epidemiol. 1991;133(11):1135-51.

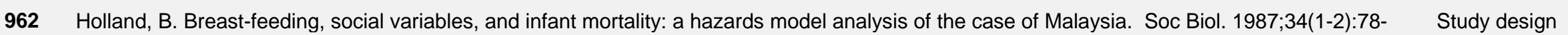
93

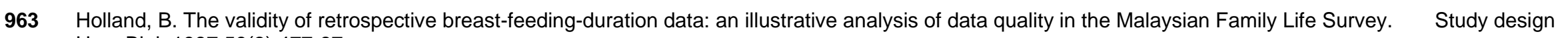
Hum Biol. 1987;59(3):477-87. weight gain in early infancy?. Br J Nutr. 2014;111(9):1696-704.

965 Holm, A. K.,Andersson, R. Enamel mineralization disturbances in 12-year-old children with known early exposure to fluorides. Community Dent Oral Epidemiol. 1982;10(6):335-9.

966 Holman, D. J.,Yamaguchi, K. Longitudinal analysis of deciduous tooth emergence: IV. Covariate effects in Japanese children. Am J Phys Anthropol. 2005;126(3):352-8.

967 Holme, A.,MacArthur, C.,Lancashire, R. The effects of breastfeeding on cognitive and neurological development of children at 9 years. Child Care Health Dev. 2010;36(4):583-90.

968 Holmes, G. E.,Hassanein, K. M.,Miller, H. C. Factors associated with infections among breast-fed babies and babies fed proprietary milks. Pediatrics. 1983;72(3):300-6.
Independent variable

Dependent variable

Independent variable

Study design

Independent variable 
Holmes, V. A.,Cardwell, C.,McKinley, M. C.,Young, I. S.,Murray, L. J.,Boreham, C. A.,Woodside, J. V. Association between breast-feeding and anthropometry and CVD risk factor status in adolescence and young adulthood: the Young Hearts Project, Northern Ireland. Public Health Nutr. 2010;13(6):771-8.

970 Holscher, H. D.,Czerkies, L. A.,Cekola, P.,Litov, R.,Benbow, M.,Santema, S.,Alexander, D. D.,Perez, V.,Sun, S.,Saavedra, J. M.,Tappenden, K. A. Bifidobacterium lactis Bb12 enhances intestinal antibody response in formula-fed infants: a randomized, double-blind, controlled trial. JPEN J Parenter Enteral Nutr. 2012;36(1 Suppl):106S-17S.

971 Holt, R. D.,Joels, D.,Winter, G. B. Caries in pre-school children. The Camden study. Br Dent J. 1982;153(3):107-9.

Study design

972 Holt, R. D.,Winter, G. B.,Downer, M. C.,Bellis, W. J.,Hay, I. S. Caries in pre-school children in Camden 1993/94. Br Dent J. 1996;181(1112):405-10.

973 Hon, K. L. E.,Leung, T. F.,Kam, W. Y. C.,Lam, M. C. A.,Fok, T. F.,Ng, P. C. Dietary restriction and supplementation in children with atopic eczema. Clinical and Experimental Dermatology. 2006;31(2):187-191.

974 Hong, L.,Levy, S. M.,Warren, J. J.,Broffitt, B. Infant breast-feeding and childhood caries: a nine-year study. Pediatr Dent. $2014 ; 36(4): 342-7$.

\section{Included for}

systematic reviews not

completed

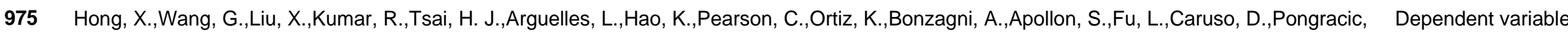
J. A.,Schleimer, R.,Holt, P. G.,Bauchner, H.,Wang, X. Gene polymorphisms, breast-feeding, and development of food sensitization in early childhood. J Allergy Clin Immunol. 2011;128(2):374-81 e2.

976 Hong, Z. Y.,Zhang, Y. W.,Xu, J. D.,Zhou, J. D.,Gao, X. L.,Liu, X. G.,Shi, Y. Y. Growth promoting effect of zinc supplementation in infants of high- $\quad$ Group size risk pregnancies. Chin Med J (Engl). 1992;105(10):844-8.

977 Honorio, R. F.,Costa Monteiro Hadler, M. C. Factors associated with obesity in brazilian children enrolled in the school health program: a casecontrol study. Nutr Hosp. 2014;30(3):526-34.

978 Hopkins, D.,Emmett, P.,Steer, C.,Rogers, I.,Noble, S.,Emond, A. Infant feeding in the second 6 months of life related to iron status: an observational study. Arch Dis Child. 2007;92(10):850-4.

979 Hopkins, D.,Steer, C. D.,Northstone, K.,Emmett, P. M. Effects on childhood body habitus of feeding large volumes of cow or formula milk compared with breastfeeding in the latter part of infancy. Am J Clin Nutr. 2015;102(5):1096-103.

980 Hopkinson, J. Is it possible for a breastfed baby to be overweight?. J Hum Lact. 2003;19(2):189-90.

Study design

981

Hoppu, U.,Kalliomaki, M.,Isolauri, E. Cow's milk allergy--a matter of fat. Allergy. 2002;57(1):61-2.

Study design,

Independent variable

982 Horby Jorgensen, M.,Holmer, G.,Lund, P.,Hernell, O.,Michaelsen, K. F. Effect of formula supplemented with docosahexaenoic acid and gammaIndependent variable linolenic acid on fatty acid status and visual acuity in term infants. J Pediatr Gastroenterol Nutr. 1998;26(4):412-21. 
983 Horst, C. H.,Obermann-de Boer, G. L.,Kromhout, D. Type of milk feeding and nutrient intake during infancy. The Leiden Pre-School Children Study. Acta Paediatr Scand. 1987;76(6):865-71.

984 Horta, B. L.,Bas, A.,Bhargava, S. K.,Fall, C. H.,Feranil, A.,de Kadt, J.,Martorell, R.,Richter, L. M.,Stein, A. D.,Victora, C. G. Infant feeding and school attainment in five cohorts from low- and middle-income countries. PLoS One. 2013;8(8):e71548.

985 Horton, C. An overview of the NUTRIMENTHE project. Nutrition Bulletin. 2012;37(2):152-156 5p.

986 Horwood, L. J.,Fergusson, D. M. Breastfeeding and later cognitive and academic outcomes. Pediatrics. 1998;101(1):E9. 1985;75(5):859-68

988 Hosseini, S. M.,Maracy, M. R.,Sarrafzade, S.,Kelishadi, R. Child weight growth trajectory and its determinants in a sample of Iranian children from birth until 2 years of age. International Journal of Preventive Medicine. 2014;5(3):348-355.

989 Host, A.,Husby, S.,Osterballe, O. A prospective study of cow's milk allergy in exclusively breast-fed infants. Incidence, pathogenetic role of early inadvertent exposure to cow's milk formula, and characterization of bovine milk protein in human milk. Acta Paediatr Scand. 1988;77(5):663-70.

990 Houston M,Howie P,McNeilly A. Nursing Mirror Midwifery Forum 4. Infant feeding. Nurs Mirror. 1983;156:i-iv.

991 Howe, L. D.,Ellison-Loschmann, L.,Pearce, N.,Douwes, J.,Jeffreys, M.,Firestone, R. Ethnic differences in risk factors for obesity in New Zealand infants. J Epidemiol Community Health. 2015;69(6):516-22.

992 Howie, P. W.,Forsyth, J. S.,Ogston, S. A.,Clark, A.,Florey, C. D. Protective effect of breast feeding against infection. BMJ. 1990;300(6716):11-6.

993 Howie, P. W.,Forsyth, J. S.,Ogston, S. A.,Clark, A.,Florey, C. Protective effect of breastfeeding against infection.. this article originally appeared in the British Medical Journal, V. 300. Reproduced with permission. Breastfeeding Review. 1990;2(1):7-15 9p.

994 Hoyle, B.,Yunus, M.,Chen, L. C. Breast-feeding and food intake among children with acute diarrheal disease. The American journal of clinical nutrition. 1980;33(11):2365-2371.

995 Hromadova, M.,Kostalova, L.,Leskova, L.,Kapellerova, A. Relationship between the duration of the breast-feeding period and the lipoprotein profile of children at the age of 13 years. Physiol Res. 1997;46(1):21-5.

996 Huang, D. Y.,Lanza, H. I.,Anglin, M. D. Trajectory of Adolescent Obesity: Exploring the Impact of Prenatal to Childhood Experiences. J Child Fam Stud. 2014;23(6):1090-1101.
Study design,

Dependent variable

Included for

systematic reviews not completed

Study design

Included for

systematic reviews not

completed

Independent variable

Independent variable

Study design

Independent variable

Study design

Independent variable

Dependent variable

\section{Included for}

systematic reviews not

completed

Included for

systematic reviews not completed

Study design, Country

Group size

Included for

systematic reviews not

completed 
999 Huang, R. C.,Mori, T. A.,Beilin, L. J. Early life programming of cardiometabolic disease in the Western Australian pregnancy cohort (Raine) study. Clinical and Experimental Pharmacology and Physiology. 2012;39(11):973-978.

Study design

1000 Huffman, S. L.,Dewey, K. G.,Schofield, D. Moving ahead with maternal, infant, and young child nutrition: need to integrate actions. Food Nut Bull. 2010;31(2 Suppl):S99.

1001 Huffman, S. L.,Lopez de Romana, G.,Madrid, S.,Brown, K. H.,Bentley, M.,Black, R. E. Do child feeding practices change due to diarrhoea in the Central Peruvian Highlands?. J Diarrhoeal Dis Res. 1991;9(4):295-300.

1002 Huh, S. Y.,Rifas-Shiman, S. L.,Taveras, E. M.,Oken, E.,Gillman, M. W. Timing of solid food introduction and risk of obesity in preschool-aged children. Pediatrics. 2011;127(3):e544-51.

1003 Hummel, M.,Fuchtenbusch, M.,Schenker, M.,Ziegler, A. G. No major association of breast-feeding, vaccinations, and childhood viral diseases with early islet autoimmunity in the German BABYDIAB Study. Diabetes Care. 2000;23(7):969-74.

1004 Hummel, S.,Pfluger, M.,Kreichauf, S.,Hummel, M.,Ziegler, A. G. Predictors of overweight during childhood in offspring of parents with type 1 diabetes. Diabetes Care. 2009;32(5):921-5.

1005 Hundt, G. A.,Forman, M. R. Interfacing anthropology and epidemiology: the Bedouin Arab Infant Feeding Study. Soc Sci Med. 1993;36(7):957-

1006 Hutchison, B. L., Thompson, J. M.,Mitchell, E. A. Infant care practices related to sudden unexpected death in infancy: a 2013 survey. N Z Med J. 2015;128(1408):15-22.

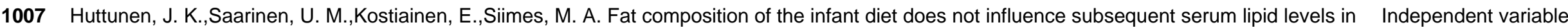
man. Atherosclerosis. 1983;46(1):87-94.

1008 Huurre, A.,Laitinen, K.,Rautava, S.,Korkeamaki, M.,Isolauri, E. Impact of maternal atopy and probiotic supplementation during pregnancy on infant sensitization: a double-blind placebo-controlled study. Clin Exp Allergy. 2008;38(8):1342-8.

1009 Huus, K.,Ludvigsson, J. F.,Enskar, K.,Ludvigsson, J. Exclusive breastfeeding of Swedish children and its possible influence on the development of obesity: a prospective cohort study. BMC Pediatr. 2008;8:42.

1010 Huybrechts, I.,De Vriendt, T.,Breidenassel, C.,Rogiers, J.,Vanaelst, B.,Cuenca-Garcia, M.,Moreno, L. A.,Gonzalez-Gross, M.,Roccaldo, R.,Kafatos, A.,Clays, E.,Bueno, G.,Beghin, L.,Sjostrom, M.,Manios, Y.,Molnar, D.,Pisa, P. T.,De Henauw, S. Mechanisms of stress, energy 
1011 Hwang, J. B.,Lee, S. H.,Kang, Y. N.,Kim, S. P.,Suh, S. I.,Kam, S. Indexes of suspicion of typical cow's milk protein-induced enterocolitis. J Korean Med Sci. 2007;22(6):993-7.

1012 Hyland, F. Breastfeeding: for those who won't. Community Outlook. 1988:11-2

Independent variable, Health status

Study design

1013 Hysing, M.,Harvey, A. G.,Torgersen, L.,Ystrom, E.,Reichborn-Kjennerud, T.,Sivertsen, B. Trajectories and predictors of nocturnal awakenings and sleep duration in infants. J Dev Behav Pediatr. 2014;35(5):309-16.

1014 Iacono, G.,Merolla, R.,D'Amico, D.,Bonci, E.,Cavataio, F.,Di Prima, L.,Scalici, C.,Indinnimeo, L.,Averna, M. R.,Carroccio, A. Gastrointestinal symptoms in infancy: a population-based prospective study. Dig Liver Dis. 2005;37(6):432-8.

1015 lannotti, L. L.,Zavaleta, N.,León, Z.,Caulfield, E. L. Growth and body composition of Peruvian infants in a peri urban setting. Food and Nutrition Bulletin. 2009;30(3):245-253.

1016 Imai, C. M.,Gunnarsdottir, I.,Thorisdottir, B.,Halldorsson, T. I.,Thorsdottir, I. Associations between infant feeding practice prior to six months and body mass index at six years of age. Nutrients. 2014;6(4):1608-17.

1017 Immunology of milk and the neonate. Adv Exp Med Biol. 1991;310:1-480.

1018 Inamo, Y.,Hasegawa, M.,Saito, K.,Hayashi, R.,Ishikawa, T.,Yoshino, Y.,Hashimoto, K.,Fuchigami, T. Serum vitamin D concentrations and associated severity of acute lower respiratory tract infections in Japanese hospitalized children. Pediatr Int. 2011;53(2):199-201.

1019 Inanç, B. B.,Şahin, D. S.,Oğuzüncül, A. F.,Bindak, R.,Mungan, F. Prevalence of obesity in elementary schools in mardin, south-eastern of turkey: Study design A preliminary study. Balkan Medical Journal. 2012;29(4):424-430.

1020 Infant feeding practices and their possible relationship to the etiology of diabetes mellitus. American Academy of Pediatrics Work Group on Cow's Milk Protein and Diabetes Mellitus. Pediatrics. 1994;94(5):752-4.

1021 Innis, S. M. Human milk and formula fatty acids. J Pediatr. 1992;120(4 Pt 2):S56-61.

1022 Innis, S. M.,Auestad, N.,Siegman, J. S. Blood lipid docosahexaenoic and arachidonic acid in term gestation infants fed formulas with high docosahexaenoic acid, low eicosapentaenoic acid fish oil. Lipids. 1996;31(6):617-25.

1023 Innis, S. M.,Diersen-Schade, D. A.,Akrabawi, S. S. Prospective evaluation of preferential looking acuity in healthy term infants fed infant formula Peer review or breast fed. Pediatric research. 1995;37(4):308a.

1024 Innis, S. M.,Friesen, R. W. Maternal DHA supplementation in pregnancy: a double blind randomized prospective trial of maternal N-3 fatty acid status, human milk fatty acids and infant development. Pediatric Academic Societies Annual Meeting; 2007 May 5-8; Toronto, Canada. 2007.

1025 Innis, S. M.,Nelson, C. M.,Lwanga, D.,Rioux, F. M.,Waslen, P. Feeding formula without arachidonic acid and docosahexaenoic acid has no effect on preferential looking acuity or recognition memory in healthy full-term infants at 9 mo of age. Am J Clin Nutr. 1996;64(1):40-6.

1026 Inostroza, J.,Haschke, F.,Steenhout, P.,Grathwohl, D.,Nelson, S. E.,Ziegler, E. E. Low-protein formula slows weight gain in infants of overweight mothers. J Pediatr Gastroenterol Nutr. 2014;59(1):70-7.
Study design

tudy design

Dependent variable

Independent variable Dependent variable

Independent variable

Independent variable

Study design

Study design

Group size

Peer review

Study design, Independent variable

Included for systematic reviews not completed 
1027 Iron-Segev, S.,Peterson, K. E.,Gillman, M. W.,Williams, C. M.,Austin, S. B.,Field, A. E. Associations of breastfeeding with bulimic behaviors and eating disorders among adolescents. Int J Eat Disord. 2013;46(8):834-40.

1028 Isaacs, C. E.,Jia, J. H. The anti-infective activity of human milk is potentially greater than the sum of its microbicidal components. Adv Exp Med Biol. 2004:554:439-41.

1029 Isaacs, E. B.,Fischl, B. R.,Quinn, B. T.,Chong, W. K.,Gadian, D. G.,Lucas, A. Impact of breast milk on intelligence quotient, brain size, and white matter development. Pediatr Res. 2010;67(4):357-62.

1030 Islam, M. A.,Rahman, M. M.,Mahalanabis, D. Maternal and socioeconomic factors and the risk of severe malnutrition in a child: a case-control study. Eur J Clin Nutr. 1994;48(6):416-24.

1031 Islam, M. A.,Rahman, M. M.,Mahalanabis, D.,Rahman, A. K. Death in a diarrhoeal cohort of infants and young children soon after discharge from hospital: risk factors and causes by verbal autopsy. J Trop Pediatr. 1996;42(6):342-7.

1032 Isolauri, E. Nutrition, allergy, mucosal immunology and intestinal microbiota: the effects of maternal nutrition during pregnancy and breast feeding on the risk of allergic disease. ClinicalTrials.gov [http://clinicaltrials.gov]. 2005.

1033 Isomura, H.,Takimoto, H.,Miura, F.,Kitazawa, S.,Takeuchi, T.,Itabashi, K.,Kato, N.. Type of milk feeding affects hematological parameters and serum lipid profile in Japanese infants. Pediatr Int. 2011;53(6):807-13.

1034 Ito, J.,Fujiwara, T. Breastfeeding and risk of atopic dermatitis up to the age 42 months: a birth cohort study in Japan. Ann Epidemiol 2014;24(4):267-72.

1035 Ivanovic, D.,Ivanovic, R.,Buitron, C. Nutritional status, birth weight and breast feeding of elementary first grade Chilean students. Nutrition Reports International. 1987;36(6):1347-1361.

1036 Ivarsson, A.,Persson, L. A.,Nystrom, L.,Ascher, H.,Cavell, B.,Danielsson, L.,Dannaeus, A.,Lindberg, T.,Lindquist, B.,Stenhammar, L.,Hernell, O. Epidemic of coeliac disease in Swedish children. Acta Paediatr. 2000;89(2):165-71.

1037 Izadi, V.,Kelishadi, R.,Qorbani, M.,Esmaeilmotlagh, M.,Taslimi, M.,Heshmat, R.,Ardalan, G.,Azadbakht, L. Duration of breast-feeding and cardiovascular risk factors among Iranian children and adolescents: the CASPIAN III study. Nutrition. 2013;29(5):744-51.

1038 J. M, Hamid Jan,Mitra, Amal K.,H, Hasmiza,C. D, Pim,L. O, Ng,W. M, Wan Manan. Effect of Gender and Nutritional Status on Academic Achievement and Cognitive Function among Primary School Children in a Rural District in Malaysia. Malaysian Journal of Nutrition. 2011;17(2):189-200 12p.

1039 Jaber, L. Preventive intervention for iron deficiency anaemia in a high risk population. Int J Risk Saf Med. 2014;26(3):155-62.

Included for

systematic reviews not completed

1040 Jackson, D. B.,Beaver, K. M. The Association Between Breastfeeding Exposure and Duration, Neuropsychological Deficits, and Psychopathic Personality Traits in Offspring: The Moderating Role of 5HTTLPR. Psychiatr Q. 2015. 

Toxicol Clin Toxicol. 2002;40(4):467-75.

1043 Jacobson, S. W.,Chiodo, L. M.,Jacobson, J. L. Breastfeeding effects on intelligence quotient in 4- and 11-year-old children. Pediatrics. 1999;103(5):e71.

1044 Jacoby, P.,Carville, K. S.,Hall, G.,Riley, T. V.,Bowman, J.,Leach, A. J.,Lehmann, D. Crowding and other strong predictors of upper respiratory tract carriage of otitis media-related bacteria in Australian Aboriginal and non-Aboriginal children. Pediatr Infect Dis J. 2011;30(6):480-5.

1045 Jaganath, D.,Saito, M.,Gilman, R. H.,Queiroz, D. M.,Rocha, G. A.,Cama, V.,Cabrera, L.,Kelleher, D.,Windle, H. J.,Crabtree, J. E.,Checkley, W. First detected Helicobacter pylori infection in infancy modifies the association between diarrheal disease and childhood growth in Peru. Helicobacter. 2014;19(4):272-9.

\begin{tabular}{|c|c|c|}
\hline 1046 & Jain, L. Our babies are what we feed them. Clin Perinatol. 2014;41(2):xv-xvii. & Study design \\
\hline 1047 & Jain, M. K.,Vora, J. N.,Kale, V. V.,Iyyer, L.,Irani, S. F. A study of non-epidemic diarrhea in the newborns. Indian Pediatr. 1984;21(1):56-60. & Country \\
\hline 1048 & Jain, R.,Acharya, A. S. Supplemental folic acid in pregnancy and childhood asthma. Natl Med J India. 2010;23(6):351-2. & Study design \\
\hline 1049 & $\begin{array}{l}\text { Jalevik, B.,Noren, J. G.,Klingberg, G.,Barregard, L. Etiologic factors influencing the prevalence of demarcated opacities in permanent first molars } \\
\text { in a group of Swedish children. Eur J Oral Sci. 2001;109(4):230-4. }\end{array}$ & Study design \\
\hline 1050 & $\begin{array}{l}\text { James, J.,Evans, J.,Male, P.,Pallister, C.,Hendrikz, J. K.,Oakhill, A. Iron deficiency in inner city pre-school children: development of a general } \\
\text { practice screening programme. J R Coll Gen Pract. 1988;38(311):250-2. }\end{array}$ & Study design \\
\hline 1051 & James, M. Child's nutritional needs: nature's wonderful formula. Nurs J India. 1986;77(7):180-1, 196. & Study design \\
\hline 1052 & $\begin{array}{l}\text { Janevic, T.,Petrovic, O.,Bjelic, I.,Kubera, A. Risk factors for childhood malnutrition in Roma settlements in Serbia. BMC Public Health. } \\
\text { 2010;10:509. }\end{array}$ & Study design \\
\hline 1053 & Janowitz, B.,Nichols, D. J. Child survivorship and pregnancy spacing in Iran. J Biosoc Sci. 1983;15(1):35-46. & Dependent variable \\
\hline 1054 & Jansen, A. A. Malnutrition and child feeding practices in the Kingdom of Tonga. J Trop Pediatr. 1982;28(4):202-8. & Study design \\
\hline 1055 & $\begin{array}{l}\text { Jansen, H.,Huiting, H. G.,Scholtens, S.,Sauer, P. J.,Stolk, R. P. HbA1c in nondiabetic Dutch infants aged 8-12 months: the GECKO-Drenthe } \\
\text { birth cohort study. Diabetes Care. 2011;34(2):403-5. }\end{array}$ & Study design \\
\hline 1056 & $\begin{array}{l}\text { Jansen, M. A., Tromp, II,Kiefte-de Jong, J. C.,Jaddoe, V. W.,Hofman, A.,Escher, J. C.,Hooijkaas, H.,Moll, H. A. Infant feeding and anti-tissue } \\
\text { transglutaminase antibody concentrations in the Generation R Study. Am J Clin Nutr. 2014;100(4):1095-101. }\end{array}$ & Dependent variable \\
\hline 1057 & $\begin{array}{l}\text { Jarvisalo, M. J.,Hutri-Kahonen, N.,Juonala, M.,Mikkila, V.,Rasanen, L.,Lehtimaki, T.,Viikari, J.,Raitakari, O. T. Breast feeding in infancy and } \\
\text { arterial endothelial function later in life. The Cardiovascular Risk in Young Finns Study. Eur J Clin Nutr. 2009;63(5):640-5. }\end{array}$ & Independent variable \\
\hline
\end{tabular}


1058 Javed, A.,Yoo, K. H.,Agarwal, K.,Jacobson, R. M.,Li, X.,Juhn, Y. J. Characteristics of children with asthma who achieved remission of asthma. J Health status Asthma. 2013;50(5):472-9.

1059 Jedrychowski, W.,Maugeri, U.,Perera, F.,Stigter, L.,Jankowski, J.,Butscher, M.,Mroz, E.,Flak, E.,Skarupa, A.,Sowa, A. Cognitive function of 6year old children exposed to mold-contaminated homes in early postnatal period. Prospective birth cohort study in Poland. Physiol Behav. 2011;104(5):989-95.

1060 Jedrychowski, W.,Perera, F.,Jankowski, J.,Butscher, M.,Mroz, E.,Flak, E.,Kaim, I.,Lisowska-Miszczyk, I.,Skarupa, A.,Sowa, A. Effect of exclusive breastfeeding on the development of children's cognitive function in the Krakow prospective birth cohort study. Eur J Pediatr. 2012;171(1):1518.

1061 Jelding-Dannemand, E.,Malby Schoos, A. M.,Bisgaard, H. Breast-feeding does not protect against allergic sensitization in early childhood and allergy-associated disease at age 7 years. J Allergy Clin Immunol. 2015;136(5):1302-1308 e13.

1062 Jelliffe DB. Recent developments in breastfeeding. Med J Malaysia. 1986;41:59-63.

Independent variable

1063 Jelliffee, E. F. Breastfeeding and the prevention of malnutrition. Med J Malaysia. 1986;41(1):88-92.

Study design

1064 Jenkins, A. L.,Gyorkos, T. W.,Joseph, L.,Culman, K. N.,Ward, B. J.,Pekeles, G. S.,Mills, E. L. Risk factors for hospitalization and infection in Canadian Inuit infants over the first year of life--a pilot study. Int J Circumpolar Health. 2004;63(1):61-70.

1065 Jenkins, J. M.,Foster, E. M. The effects of breastfeeding exclusivity on early childhood outcomes. Am J Public Health. 2014;104 Suppl 1:S12835

Study design

Group size

Included for

systematic reviews not completed

1066 Jensen, B. H.,Röser, D.,Andreassen, B. U.,Olsen, K. E. P.,Nielsen, H. V.,Roldgaard, B. B.,Schjørring, S.,Mirsepasi-Lauridsen, H. C.,Jørgensen, S. L.,Mortensen, E. M.,Petersen, A. M.,Krogfelt, K. A. Childhood diarrhoea in Danish day care centres could be associated with infant colic, low birthweight and antibiotics. Acta Paediatrica, International Journal of Paediatrics. 2015.

1067 Jensen, C. L.,Prager, T. C.,Fraley, J. K.,Chen, H.,Anderson, R. E.,Heird, W. C. Effect of dietary linoleic/alpha-linolenic acid ratio on growth and visual function of term infants. J Pediatr. 1997;131(2):200-9.

1068 Jensen, C. L.,Prager, T. C.,Zou, Y.,Fraley, J. K.,Maude, M.,Anderson, R. E.,Heird, W. C. Effects of maternal docosahexaenoic acid supplementation on visual function and growth of breast-fed term infants. Lipids. 1999;34 Suppl:S225.

Independent variable

Jensen, E. T.,Kappelman, M. D.,Kim, H. P.,Ringel-Kulka, T.,Dellon, E. S. Early life exposures as risk factors for pediatric eosinophilic esophagitis. J Pediatr Gastroenterol Nutr. 2013;57(1):67-71.

1070 Jensen, S. M.,Ritz, C.,Ejlerskov, K. T.,Molgaard, C.,Michaelsen, K. F. Infant BMI peak, breastfeeding, and body composition at age 3 y. Am J Clin Nutr. 2015;101(2):319-25

1071 Jensen, T. K.,Grandjean, P.,Jorgensen, E. B.,White, R. F.,Debes, F.,Weihe, P. Effects of breast feeding on neuropsychological development in a community with methylmercury exposure from seafood. J Expo Anal Environ Epidemiol. 2005;15(5):423-30. 
1073 Jiang, M.,Foster, E. M. Duration of breastfeeding and childhood obesity: a generalized propensity score approach. Health Serv Res. 2013;48(2 Pt 1):628-51.

Included for

systematic reviews not completed

1074 Jiang, M.,Foster, E. M.,Gibson-Davis, C. M. Breastfeeding and the child cognitive outcomes: a propensity score matching approach. Matern Included for Child Health J. 2011;15(8):1296-307.

systematic reviews not completed

1075 Jin, C.,MacKay Rossignol, A. Effects of passive smoking on respiratory illness from birth to age eighteen months, in Shanghai, People's Republic of China. Journal of Pediatrics. 1993;123(4):553-558.

Study design, Independent variable

1076 Jin, H. J.,Lee, J. H.,Kim, M. K. The prevalence of vitamin D deficiency in iron-deficient and normal children under the age of 24 months. Blood Study design Research. 2013;48(1):40-45

1077 Jing, H.,Gilchrist, J. M.,Badger, T. M.,Pivik, R. T. A longitudinal study of differences in electroencephalographic activity among breastfed, milk formula-fed, and soy formula-fed infants during the first year of life. Early Hum Dev. 2010;86(2):119-25.

Included for

systematic reviews not completed

1078 Jing, H.,Pivik, R. T.,Dykman, R. A.,Gilchrist, J. M.,Badger, T. M. Effects of breast milk and milk formula diets on synthesized speech soundinduced event-related potentials in 3- and 6-month-old infants. Dev Neuropsychol. 2007;31(3):349-62.

1079 Jing, H.,Xu, H.,Wan, J.,Yang, Y.,Ding, H.,Chen, M.,Li, L.,Lv, P.,Hu, J.,Yang, J. Effect of breastfeeding on childhood BMI and obesity: the China Family Panel Studies. Medicine (Baltimore). 2014;93(10):e55.

1080 Jochum, F.,Fuchs, A.,Cser, A.,Menzel, H.,Lombeck, I. Trace mineral status of full-term infants fed human milk, milk-based formula or partially hydrolysed whey protein formula. Analyst. 1995;120(3):905-9.

Included for

systematic reviews not completed

Included for

systematic reviews not completed

Study design

Independent variable

Study design

Study design Pediatr Dent. 1986;8(3):168-70.

1084 Johnsen, D. C.,Gerstenmaier, J. H.,Schwartz, E.,Michal, B. C.,Parrish, S. Background comparisons of pre-31/2-year-old children with nursing caries in four practice settings. Pediatr Dent. 1984;6(1):50-4.

1085 Johnson, C. A.,Lieberman, B.,Hassanein, R. E. The relationship of breast feeding to third-day bilirubin levels. J Fam Pract. 1985;20(2):147-52.

Study design, Independent variable 
1086 Johnson, C. C., Ownby, D. R.,Alford, S. H.,Havstad, S. L.,Williams, L. K.,Zoratti, E. M.,Peterson, E. L.,Joseph, C. L. Antibiotic exposure in early infancy and risk for childhood atopy. J Allergy Clin Immunol. 2005;115(6):1218-24.

1087 Johnson, D. L.,Swank, P. R.,Howie, V. M.,Baldwin, C. D.,Owen, M. Breast feeding and children's intelligence. Psychol Rep. 1996;79(3 Pt 2):1179-85.

Dependent variable

Included for

systematic reviews not

completed

1088 Johnson, L.,van Jaarsveld, C. H.,Llewellyn, C. H.,Cole, T. J.,Wardle, J. Associations between infant feeding and the size, tempo and velocity of infant weight gain: SITAR analysis of the Gemini twin birth cohort. Int J Obes (Lond). 2014;38(7):980-7.

Included for

systematic reviews not completed

1089 Johnston, B. D.,Huebner, C. E.,Anderson, M. L.,Tyll, L. T.,Thompson, R. S. Healthy steps in an integrated delivery system: child and parent outcomes at 30 months. Arch Pediatr Adolesc Med. 2006;160(8):793-800.

Included for

systematic reviews not completed

1090 Johnston, P. K. Getting enough to grow on. Am J Nurs. 1984;84(3):336-9.

Study design

Independent variable

Dependent variable

1091 Jonas, W.,Atkinson, L.,Steiner, M.,Meaney, M. J.,Wazana, A.,Fleming, A. S. Breastfeeding and maternal sensitivity predict early infant temperament. Acta Paediatr. 2015;104(7):678-86.

Included for systematic reviews not completed

1092 Jones EG,Matheny RJ. Relationship between infant feeding and exclusion rate from child care because of illness. J Am Diet Assoc.

Study design 1993;93:809-11.

Dependent variable

1093 Jones, A. INTERGENERATIONAL EDUCATIONAL ATTAINMENT, FAMILY CHARACTERISTICS AND CHILD OBESITY. J Biosoc Sci. 2015:1- Study design 20.

1094 Jones, D. Infant feeding. Breast-feeding practices. Nurs Times. 1987;83(3):56-7.

Dependent variable

1095 Jones, F.,Green, M. The B.C. Baby-Friendly Initiative. Nurs BC. 1996;28(5):7-8.

Study design

1096 Jones, G.,Hynes, K. L.,Dwyer, T. The association between breastfeeding, maternal smoking in utero, and birth weight with bone mass and fractures in adolescents: a 16-year longitudinal study. Osteoporos Int. 2013;24(5):1605-11.

Included for systematic reviews not completed

1097 Jones, G.,Riley, M.,Dwyer, T. Breastfeeding in early life and bone mass in prepubertal children: a longitudinal study. Osteoporos Int. 2000;11(2):146-52.

Included for systematic reviews not completed

1098 Jones, I. E.,Williams, S. M.,Goulding, A. Associations of birth weight and length, childhood size, and smoking with bone fractures during growth: evidence from a birth cohort study. Am J Epidemiol. 2004;159(4):343-50. 
1099 Jones, M. E.,Swerdlow, A. J.,Gill, L. E.,Goldacre, M. J. Pre-natal and early life risk factors for childhood onset diabetes mellitus: a record linkage study. Int J Epidemiol. 1998;27(3):444-9.

1100 Jones, N. A.,McFall, B. A.,Diego, M. A. Patterns of brain electrical activity in infants of depressed mothers who breastfeed and bottle feed: the mediating role of infant temperament. Biol Psychol. 2004;67(1-2):103-24.

1101 Jones, S. M.,Steele, R. W. Recurrent group B streptococcal bacteremia. Clin Pediatr (Phila). 2012;51(9):884-7.

Group size

Study design

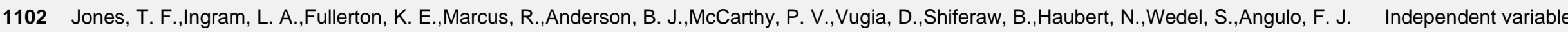
A case-control study of the epidemiology of sporadic Salmonella infection in infants. Pediatrics. 2006;118(6):2380-7.

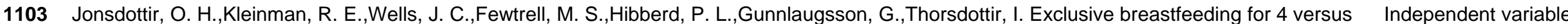
6 months and growth in early childhood. Acta Paediatr. 2014;103(1):105-11.

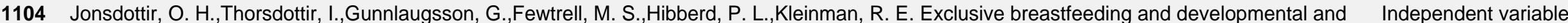
behavioral status in early childhood. Nutrients. 2013;5(11):4414-28.

1105 Jonsdottir, O. H.,Thorsdottir, I.,Hibberd, P. L.,Fewtrell, M. S.,Wells, J. C.,Palsson, G. I.,Lucas, A., Gunnlaugsson, G., Kleinman, R. E. Timing of the introduction of complementary foods in infancy: a randomized controlled trial. Pediatrics. 2012;130(6):1038-45.

1106 Jonville-Béra, A. P.,Autret-Leca, E.,Barbeillon, F.,Paris-Llado, J. Sudden unexpected death in infants under 3 months of age and vaccination status - A case-control study. British Journal of Clinical Pharmacology. 2001;51(3):271-276.

1107 Jonville-Bera, A. P.,Autret-Leca, E.,Barbeillon, F.,Paris-Llado, J. Sudden unexpected death in infants under 3 months of age and vaccination status- -a case-control study. Br J Clin Pharmacol. 2001;51(3):271-6.

1108 Jooste, P. L.,Rossouw, L. J.,Steenkamp, H. J.,Rossouw, J. E.,Swanepoel, A. S.,Charlton, D. O. Effect of breast feeding on the plasma cholesterol and growth of infants. J Pediatr Gastroenterol Nutr. 1991;13(2):139-42.

1109 Jovanovic, D.,llic, N.,Miljkovic-Selimovic, B.,Djokic, D.,Relic, T.,Tambur, Z.,Doder, R.,Kostic, G. Campylobacter jejuni infection and IgE sensitization in up to 2-year-old infants. Vojnosanit Pregl. 2015;72(2):140-7.

1110 Joventino, Emanuella Silva,Gomes Coutinho, Robson, de Castro Bezerra, Karine,de Almeida, Paulo CÃ@sar,Oliveira Batista Ori $\tilde{A}_{i}$, MÃ'nica,Barbosa Ximenes, Lorena. Self-effectiveness in preventing diarrhea and child care: a transversal study. Online Brazilian Journal of Nursing. 2013;12(2):1-1 1p.

1111 Juambeltz, J. C.,Kula, K.,Perman, J. Nursing caries and lactose intolerance. ASDC J Dent Child. 1993;60(4):377-84.

1112 Juez, G.,Diaz, S.,Casado, M. E.,Duran, E.,Salvatierra, A. M.,Peralta, O.,Croxatto, H. B. Growth pattern of selected urban Chilean infants during exclusive breast-feeding. Am J Clin Nutr. 1983;38(3):462-8.

1113 Juliusson, P. B.,Roelants, M.,Hoppenbrouwers, K.,Hauspie, R.,Bjerknes, R. Growth of Belgian and Norwegian children compared to the WHO growth standards: prevalence below -2 and above +2 SD and the effect of breastfeeding. Arch Dis Child. 2011;96(10):916-21

Independent variable

cluded for

ystematic reviews not

Included for

systematic reviews not completed

Country

\section{Study design}

Study design

Study design 
1114 Julvez, J.,Guxens, M.,Carsin, A. E.,Forns, J.,Mendez, M.,Turner, M. C.,Sunyer, J. A cohort study on full breastfeeding and child neuropsychological development: the role of maternal social, psychological, and nutritional factors. Dev Med Child Neurol. 2014;56(2):148-56.

Included for

systematic reviews not completed

Included for systematic reviews not completed

Study design Independent variable

Independent variable

1117 Jung, E.,Czajka-Narins, D. M. Birth weight doubling and tripling times: an updated look at the effects of birth weight, sex, race and type of feeding. Am J Clin Nutr. 1985;42(2):182-9.

1118 Just, J.,Belfar, S.,Wanin, S.,Pribil, C.,Grimfeld, A.,Duru, G. Impact of innate and environmental factors on wheezing persistence during childhood. J Asthma. 2010;47(4):412-6.

1119 Juto, P.,Moller, C.,Engberg, S.,Bjorksten, B. Influence of type of feeding on lymphocyte function and development of infantile allergy. Clin Allergy. 1982;12(4):409-16.

1120 Juvonen, P.,Mansson, M.,Andersson, C.,Jakobsson, I. Allergy development and macromolecular absorption in infants with different feeding regimens during the first three days of life. A three-year prospective follow-up. Acta Paediatr. 1996;85(9):1047-52

1121 Jwa, S. C.,Fujiwara, T.,Kondo, N. Latent protective effects of breastfeeding on late childhood overweight and obesity: a nationwide prospective study. Obesity (Silver Spring). 2014;22(6):1527-37.

1122 Kaatsch, P.,Kaletsch, U.,Krummenauer, F.,Meinert, R.,Miesner, A.,Haaf, G.,Michaelis, J. Case control study on childhood leukemia in Lower Saxony, Germany. Basic considerations, methodology, and summary of results. Klin Padiatr. 1996;208(4):179-85.

1123 Kadziela-Olech, H.,Piotrowska-Jastrzebska, J. The duration of breastfeeding and attention deficit hyperactivity disorder. Rocz Akad Med Bialymst. 2005;50:302-6.

1124 Kafouri, S.,Kramer, M.,Leonard, G.,Perron, M.,Pike, B.,Richer, L.,Toro, R., Veillette, S.,Pausova, Z.,Paus, T. Breastfeeding and brain structure in $\quad$ Study design adolescence. Int J Epidemiol. 2013;42(1):150-9.

1125 Kajosaari, M. Atopy prevention in childhood: the role of diet. Prospective 5-year follow-up of high-risk infants with six months exclusive breastfeeding and solid food elimination. Pediatr Allergy Immunol. 1994;5(6 Suppl):26-8.

1126 Kajosaari, M. Atopy prophylaxis in high-risk infants. Prospective 5-year follow-up study of children with six months exclusive breastfeeding and solid food elimination. Adv Exp Med Biol. 1991;310:453-8.

1127 Kajosaari, M.,Saarinen, U. M. Prophylaxis of atopic disease by six months' total solid food elimination. Evaluation of 135 exclusively breast-fed infants of atopic families. Acta Paediatr Scand. 1983;72(3):411-4.
Health status

Group size

Independent variable

Included for

systematic reviews not completed

Study design,

Independent variable

Included for

systematic reviews not

Independent variable

Peer review

Independent variable 
1128 Kale, A.,Deardorff, J.,Lahiff, M.,Laurent, C.,Greenspan, L. C.,Hiatt, R. A.,Windham, G.,Galvez, M. P.,Biro, F. M.,Pinney, S. M.,Teitelbaum, S. L.,Wolff, M. S.,Barlow, J.,Mirabedi, A.,Lasater, M.,Kushi, L. H. Breastfeeding versus formula-feeding and girls' pubertal development. Matern Child Health J. 2015;19(3):519-27.

1129 Kalies, H.,Heinrich, J.,Borte, N.,Schaaf, B.,von Berg, A.,von Kries, R.,Wichmann, H. E.,Bolte, G. The effect of breastfeeding on weight gain in infants: results of a birth cohort study. Eur J Med Res. 2005;10(1):36-42.

1130 Kallio, M. J.,Salmenpera, L.,Siimes, M. A.,Perheentupa, J.,Miettinen, T. A. Tracking of serum cholesterol and lipoprotein levels from the first year of life. Pediatrics. 1993;91(5):949-54.

1131 Kallio, M. J.,Salmenpera, L.,Siimes, M. A.,Perheentupa, J.,Miettinen, T. A.. Exclusive breast-feeding and weaning: effect on serum cholesterol and lipoprotein concentrations in infants during the first year of life. Pediatrics. 1992;89(4 Pt 1):663-6.

1132 Kalliomaki, M.,Isolauri, E. Breastfeeding and atopic sensitisation. Adv Exp Med Biol. 2000;478:389-90.

1133 Kalliomäki, M.,Salminen, S.,Arvilommi, H. Prenatal and postnatal administration of Lactobacillus GG reduced the occurence of atopic disease in offspring. Evidence-Based Medicine. 2001;6(6):178.

1134 Kamer, B.,Raczynska, J.,Kaczmarek, J.,Lukamowicz, J.,Pasowska, R.,Puchala, B. Genetic and environmental conditions involved in assessment of the immunological state in children with atopic dermatitis. Rocz Akad Med Bialymst. 1995;40(3):439-47.

1135 Kanazawa, S. Breastfeeding is positively associated with child intelligence even net of parental IQ. Dev Psychol. 2015;51(12):1683-9.

1136 Kaplan, B. A.,Mascie-Taylor, C. G. Biosocial factors in the epidemiology of childhood asthma in a British national sample. J Epidemiol Community Health. 1985;39(2):152-6.

1137 Karaguzel, G.,Ozer, S.,Akcurin, S.,Turkkahraman, D.,Bircan, I. Type 1 diabetes-related epidemiological, clinical and laboratory findings. An evaluation with special regard to autoimmunity in children. Saudi Med J. 2007;28(4):584-9.

1138 Karakoç, G. B.,Altintaş, D. U.,Yilmaz, M.,Kendirli, S. G. Prick Skin Test Results in Children Less Than Three Years-Old. Annals of Medical Sciences. 2003;12(3):85-88

1139 Karaolis-Danckert, N.,Buyken, A. E.,Kulig, M.,Kroke, A.,Forster, J.,Kamin, W.,Schuster, A.,Hornberg, C.,Keil, T.,Bergmann, R. L.,Wahn, U.,Lau, S. How pre- and postnatal risk factors modify the effect of rapid weight gain in infancy and early childhood on subsequent fat mass development: results from the Multicenter Allergy Study 90. Am J Clin Nutr. 2008;87(5):1356-64.

1140 Karaolis-Danckert, N.,Buyken, A. E.,Sonntag, A.,Kroke, A. Birth and early life influences on the timing of puberty onset: results from the DONALD (DOrtmund Nutritional and Anthropometric Longitudinally Designed) Study. Am J Clin Nutr. 2009;90(6):1559-65.

1141 Karaolis-Danckert, N.,Gunther, A. L.,Kroke, A.,Hornberg, C.,Buyken, A. E. How early dietary factors modify the effect of rapid weight gain in infancy on subsequent body-composition development in term children whose birth weight was appropriate for gestational age. Am J Clin Nutr. 2007;86(6):1700-8
Study design

Dependent variable

Independent variable

Independent variable

Dependent variable

Study design

Study design

Study design, Health status

Included for systematic reviews not completed

Independent variable

Health status

Health status

Included for

systematic reviews not completed

Dependent variable

Independent variable 
1142 Karino, S.,Okuda, T.,Uehara, Y.,Toyo-oka, T. Breastfeeding and prevalence of allergic diseases in Japanese university students. Ann Allergy Asthma Immunol. 2008;101(2):153-9.

1143 Karjalainen, S.,Ronning, O.,Lapinleimu, H.,Simell, O. Association between early weaning, non-nutritive sucking habits and occlusal anomalies in 3-year-old Finnish children. Int J Paediatr Dent. 1999;9(3):169-73.

1144 Kaseb, F.,Kimiagar, M.,Ghafarpoor, M.,Valaii, N. Effect of traditional food supplementation during pregnancy on maternal weight gain and birthweight. Int J Vitam Nutr Res. 2002;72(6):389-93.

Group size

1145 Kasla, R. R.,Bavdekar, S. B.,Joshi, S. Y.,Hathi, G. S. Exclusive breastfeeding: protective efficacy. Indian J Pediatr. 1995;62(4):449-53.

Country

1146 Kass, R. B.,Meumann, F. Hospitalisation for childhood diarrhoea in Central Australia. Aust Clin Rev. 1985;5(19):178-83.

Study design, Health status

1147 Kaste, L. M.,Marianos, D.,Chang, R.,Phipps, K. R. The assessment of nursing caries and its relationship to high caries in the permanent dentition. 1992. J Indiana Dent Assoc. 2010;89(2):20-4.

1148 Kato, T.,Yorifuji, T.,Yamakawa, M.,Inoue, S.,Saito, K.,Doi, H.,Kawachi, I. Association of breast feeding with early childhood dental caries:

Japanese population-based study. BMJ Open. 2015;5(3):e006982.

Independent variable

Included for

systematic reviews not completed

1149 Katoku, Y.,Yamada, M.,Yonekubo, A.,Kuwata, T.,Kobayashi, A.,Sawa, A. Effect of the cholesterol content of a formula on the lipid compositions Group size of plasma lipoproteins and red blood cell membranes in early infancy. Am J Clin Nutr. 1996;64(6):871-7.

1150 Kaufman, H. S.,Frick, O. L. Prevention of asthma. Clin Allergy. 1981;11(6):549-53

1151 Kaur, N.,Deol, R.,Yadav, A. Correlation of feeding practices and health profile of children. Nurs J India. 2014;105(3):128-30. Country

1152 Kawai, T.,Goto, A.,Watanabe, E.,Nagasawa, M.,Yasumura, S. Lower respiratory tract infections and gastrointestinal infections among mature babies in Japan. Pediatr Int. 2011;53(4):431-45.

1153 Kazemi, A.,Tabatabaie, F.,Agha-Ghazvini, M. R.,Kelishadi, R. The role of rotavirus in acute pediatric diarrhea in Isfahan, Iran. Pakistan Journal of Medical Sciences. 2006;22(3):282-285.

1154 Keim, S. A.,Daniels, J. L.,Siega-Riz, A. M.,Herring, A. H.,Dole, N.,Scheidt, P. C. Breastfeeding and long-chain polyunsaturated fatty acid intake in the first 4 post-natal months and infant cognitive development: an observational study. Matern Child Nutr. 2012;8(4):471-82.

Included for

systematic reviews not completed

1155 Kellberger, J.,Dressel, H.,Vogelberg, C.,Leupold, W.,Windstetter, D.,Weinmayr, G.,Genuneit, J.,Heumann, C.,Nowak, D.,von Mutius, E.,Radon, Independent variable $\mathrm{K}$. Prediction of the incidence and persistence of allergic rhinitis in adolescence: a prospective cohort study. J Allergy Clin Immunol. 2012;129(2):397-402, 402 e1-3.

1156 Keller, K. M.,Burgin-Wolff, A.,Lippold, R.,Wirth, S.,Lentze, M. J. The diagnostic significance of IgG cow's milk protein antibodies re-evaluated. Eur J Pediatr. 1996;155(4):331-7. 
1157 Keller, K. M.,Burgin-Wolff, A.,Menger, H.,Lippold, R.,Wirth, S.,Baumann, W. IgG, IgA, and IgE antibodies to cow milk proteins in an allergy prevention study. Adv Exp Med Biol. 1991;310:467-73.

Independent variable Dependent variable

Dependent variable first year of life and their relationship to feeding regimen and the development of food allergy. J Allergy Clin Immunol. 1991;87(5):920-9.

1159 Kennedy, K.,Fewtrell, M. S.,Morley, R.,Abbott, R.,Quinlan, P. T.,Wells, J. C.,Bindels, J. G.,Lucas, A. Double-blind, randomized trial of a synthetic triacylglycerol in formula-fed term infants: effects on stool biochemistry, stool characteristics, and bone mineralization. Am $\mathrm{J}$ Clin Nutr. 1999;70(5):920-7.

1160 Kero, P.,Piekkala, P. Factors affecting the occurrence of acute otitis media during the first year of life. Acta Paediatr Scand. 1987;76(4):618-23.

1161 Kerr, A. A. Lower respiratory tract illness in Polynesian infants. N Z Med J. 1981;93(684):333-5.

1162 Keusch, G. T. Homing in on interventions in the malnutrition-infection complex. Am J Clin Nutr. 1980;33(4):727-9.

1163 Khadivzadeh, T.,Parsai, S. Effect of exclusive breastfeeding and complementary feeding on infant growth and morbidity. East Mediterr Health J. 2004;10(3):289-94.

1164 Khalili, H.,Ananthakrishnan, A. N.,Higuchi, L. M.,Richter, J. M.,Fuchs, C. S.,Chan, A. T. Early life factors and risk of inflammatory bowel disease in adulthood. Inflamm Bowel Dis. 2013;19(3):542-7.

1165 Khan, F.,Green, F. C.,Forsyth, J. S.,Greene, S. A.,Newton, D. J.,Belch, J. J. The beneficial effects of breastfeeding on microvascular function in 11- to 14-year-old children. Vasc Med. 2009;14(2):137-42.

1166 Khanjanasthiti, P.,Nanna, P.,Sawongtrakul, S. Breast feeding in early neonatal period. J Med Assoc Thai. 1986;69 Suppl 2:100-6.

1167 Khanolkar, A. R.,Sovio, U.,Bartlett, J. W.,Wallby, T.,Koupil, I. Socioeconomic and early-life factors and risk of being overweight or obese in children of Swedish- and foreign-born parents. Pediatr Res. 2013;74(3):356-63.

1168 Khedr, E. M.,Farghaly, W. M.,Amry Sel, D.,Osman, A. A. Neural maturation of breastfed and formula-fed infants. Acta Paediatr. 2004;93(6):734- Country 8.

1169 Kholdi, N.,Zayeri, F.,Bagheban, A. A.,Khodakarim, S.,Ramezankhani, A. A study of growth failure and its related factors in children from 0 to 2 years in Tehran, Iran. Turk J Pediatr. 2012;54(1):38-44.

1170 Kiechl-Kohlendorfer, U.,Horak, E.,Mueller, W.,Strobl, R.,Haberland, C.,Fink, F. M.,Schwaiger, M.,Gutenberger, K. H.,Reich, H.,Meraner, D.,Kiechl, S. Neonatal characteristics and risk of atopic asthma in schoolchildren: results from a large prospective birth-cohort study. Acta Paediatr. 2007;96(11):1606-10.

1171 Kiechl-Kohlendorfer, U.,Peglow, U. P.,Kiechl, S.,Oberaigner, W.,Sperl, W. Epidemiology of sudden infant death syndrome (SIDS) in the Tyrol before and after an intervention campaign. Wien Klin Wochenschr. 2001;113(1-2):27-32.
Dependent variable

Study design

Dependent variable

Independent variable

systematic reviews not completed

cluded for

systematic reviews not completed

Independent variable

Independent variable

Independent variable

Included fo

systematic reviews not completed

Independent variable

Study design,

Independent variable 
1172 Kieviet, N.,Hoppenbrouwers, C.,Dolman, K. M.,Berkhof, J.,Wennink, H.,Honig, A. Risk factors for poor neonatal adaptation after exposure to antidepressants in utero. Acta Paediatr. 2015;104(4):384-91.

1173 Kim, C. S.,Jung, H. W.,Yoo, K. Y. Prevalence and risk factors of chronic otitis media in Korea: results of a nation-wide survey. Acta Otolaryngol. Study design $1993 ; 113(3): 369-75$

1174 Kim, H. S.,Kim, Y. H.,Kim, M. J.,Lee, H. S.,Han, Y. K.,Kim, K. W.,Sohn, M. H.,Kim, K. E. Effect of breastfeeding on lung function in asthmatic children. Allergy Asthma Proc. 2015;36(2):116-22.

Study design, Health

status

1175 Kim, I.,Pollitt, E. Differences in the pattern of weight growth of nutritionally at-risk and well-nourished infants. Am J Clin Nutr. 1987;46(1):31-5.

Independent variable

1176 Kim, S. K.,Cheong, W. S.,Jun, Y. H.,Choi, J. W.,Son, B. K. Red blood cell indices and iron status according to feeding practices in infants and young children. Acta Paediatr. 1996;85(2):139-44.

Study design, Health status

1177 Kimpimaki, T.,Erkkola, M.,Korhonen, S.,Kupila, A.,Virtanen, S. M.,llonen, J.,Simell, O.,Knip, M. Short-term exclusive breastfeeding predisposes young children with increased genetic risk of Type I diabetes to progressive beta-cell autoimmunity. Diabetologia. 2001;44(1):63-9.

1178 King, D. E. Statistics. Adult intelligence and breastfeeding. International Journal of Childbirth Education. 2002;17(4):23-23 1p.

Dependent variable

1179 Kiris, M.,Muderris, T.,Kara, T.,Bercin, S.,Cankaya, H.,Sevil, E. Prevalence and risk factors of otitis media with effusion in school children in Eastern Anatolia. International Journal of Pediatric Otorhinolaryngology. 2012;76(7):1030-1035.

1180 Kitsantas, P.,Gaffney, K. F. Risk profiles for overweight/obesity among preschoolers. Early Hum Dev. 2010;86(9):563-8.

Peer review

Study design

Included for

systematic reviews not completed

1181 Kjellman, N. I. Epidemiology and prevention of allergy. Allergy. 1988;43 Suppl 8:39-40.

Study design

1182 Klag, E. A.,McNamara, K.,Geraghty, S. R.,Keim, S. A. Associations Between Breast Milk Feeding, Introduction of Solid Foods, and Weight Gain Study design in the First 12 Months of Life. Clin Pediatr (Phila). 2015;54(11):1059-67.

1183 Klein, I.,Reif, S.,Farbstein, H.,Halak, A.,Gilat, T. Preillness non dietary factors and habits in inflammatory bowel disease. Ital J Gastroenterol Hepatol. 1998;30(3):247-51.

1184 Klein, J. O. Prevention of recurrent acute otitis media. Seminars in Pediatric Infectious Diseases. 1997;8(2):101-104.

Independent variable

1185 Klenovics, K. S.,Boor, P.,Somoza, V.,Celec, P.,Fogliano, V.,Sebekova, K. Advanced glycation end products in infant formulas do not contribute to insulin resistance associated with their consumption. PLoS One. 2013;8(1):e53056.

1186 Klonoff-Cohen, H. S.,Edelstein, S. L.,Lefkowitz, E. S.,Srinivasan, I. P.,Kaegi, D.,Chang, J. C.,Wiley, K. J. The effect of passive smoking and tobacco exposure through breast milk on sudden infant death syndrome. JAMA. 1995;273(10):795-8.

1187 Knight, S. M.,Toodayan, W.,Caique, W. C.,Kyi, W.,Barnes, A.,Desmarchelier, P. Risk factors for the transmission of diarrhoea in children: a case-control study in rural Malaysia. Int J Epidemiol. 1992;21(4):812-8.

Study design

Study design

Included for

systematic reviews not completed

Health status 
1190 Koch, A.,Molbak, K.,Homoe, P.,Sorensen, P.,Hjuler, T.,Olesen, M. E.,Pejl, J.,Pedersen, F. K.,Olsen, O. R.,Melbye, M. Risk factors for acute respiratory tract infections in young Greenlandic children. Am J Epidemiol. 2003;158(4):374-84.

Included for

systematic reviews not completed

1191 Kocturk, T. Infant feeding pattern in three districts of Istanbul. J Trop Pediatr. 1988;34(4):193-7.

Study design

Dependent variable

1192 Koehoorn, M.,Karr, C. J.,Demers, P. A.,Lencar, C.,Tamburic, L.,Brauer, M. Descriptive epidemiological features of bronchiolitis in a populationbased cohort. Pediatrics. 2008;122(6):1196-203.

Included for

systematic reviews not completed

1193 Koenig, H. F. Breastfeeding education for healthier babies. Baby-Friendly designation improves infant, mother and community health. Healthc Study design Exec. 2014;29(4):46, 48-9.

1194 Koh, T. H. Breast feeding among the Chinese in four countries. J Trop Pediatr. 1981;27(2):88-91.

Study design,

Dependent variable

1195 Kohler, L.,Meeuwisse, G.,Mortensson, W. Food intake and growth of infants between six and twenty-six weeks of age on breast milk, cow's milk Group size formula, or soy formula. Acta Paediatr Scand. 1984;73(1):40-8.

1196 Kohn, G.,Sawatzki, G.,van Biervliet, J. P.,Rosseneu, M. Diet and the essential fatty acid status of term infants. Acta Paediatr Suppl. 1994;402:69-74.

Included for systematic reviews not completed

1197 Kolacek, S.,Kapetanovic, T.,Luzar, V. Early determinants of cardiovascular risk factors in adults. B. Blood pressure. Acta Paediatr. 1993;82(4):377-82.

1198 Kolacek, S.,Kapetanovic, T.,Zimolo, A.,Luzar, V. Early determinants of cardiovascular risk factors in adults. A. Plasma lipids. Acta Paediatr. 1993;82(8):699-704.

1199 Koletzko S. 2.5 Allergy Prevention through Early Nutrition. World Rev Nutr Diet. 2015;113:113-7.

Group size

Group size

Peer review

1200 Koletzko, B. 2.2 Formula feeding. World Rev Nutr Diet. 2015;113:97-103.

Study design

1201 Koletzko, B.,Beyer, J.,Brands, B.,Demmelmair, H.,Grote, V.,Haile, G.,Gruszfeld, D.,Rzehak, P.,Socha, P.,Weber, M. Early influences of nutrition Study design on postnatal growth. Nestle Nutr Inst Workshop Ser. 2013;71:11-27. 1202 Koletzko, B.,Grote, V.,Schiess, S.,Verwied-Jorky, S.,Brands, B.,Demmelmair, H.,Kries, R. Prevention of pediatric obesity through baby nutrition.
[German]. Monatsschrift fur Kinderheilkunde. 2010;158(6):553-63. 
1203 Koletzko, B.,Schiess, S.,Brands, B.,Haile, G.,Demmelmair, H.,Kries, R.,Grote, V. [Infant feeding practice and later obesity risk. Indications for early metabolic programming]. Bundesgesundheitsblatt, Gesundheitsforschung, Gesundheitsschutz. 2010;53(7):666-73.

1204 Koletzko, B.,Toschke, A. M.,Vignerova, J.,Osancova, K.,Von Kries, R. Does breast feeding protect against later overweight and obesity? Cesko-Slovenska Pediatrie. 2003;58(1):3-9.

1205 Koletzko, B.,von Kries, R. Are there long term protective effects of breast feeding against later obesity?. Pediatria Wspolczesna. 2002;4(3):217- Language 223.

1206 Koletzko, B.,Von Kries, R.,Closa, R.,Escribano, J.,Scaglioni, S.,Giovannini, M.,Beyer, J.,Demmelmair, H.,Gruszfeld, D.,Dobrzanska, A.,Sengier, A.,Langhendries, J. P.,Cachera, M. F. R.,Grote, V. Lower protein in infant formula is associated with lower weight up to age 2 y: A randomized clinical trial. American Journal of Clinical Nutrition. 2009;89(6):1836-1845.

1207 Koletzko, B.,von, K. R.,Closa, R.,Escribano, J.,Scaglioni, S.,Giovannini, M.,Beyer, J.,Demmelmair, H.,Anton, B.,Gruszfeld, D.,Dobrzanska, A.,Sengier, A.,Langhendries, J. P.,Rolland Cachera, M. F.,Grote, V. Can infant feeding choices modulate later obesity risk?. American journal of clinical nutrition. 2009;89(5):1502s-1508s.

1208 Koloski, N. A.,Jones, M.,Weltman, M.,Kalantar, J.,Bone, C.,Gowryshankar, A.,Walker, M. M.,Talley, N. J. Identification of early environmental risk factors for irritable bowel syndrome and dyspepsia. Neurogastroenterol Motil. 2015;27(9):1317-25.

1209 Koopman, J. S.,Turkish, V. J.,Monto, A. S. Infant formulas and gastrointestinal illness. Am J Public Health. 1985;75(5):477-80.

Included for

systematic reviews not completed

Study design

Dependent variable

Included for

systematic reviews not completed

1210 Kosse, F. The Nutritional and Social Environment-Related Effects of Breastfeeding on Intelligence. JAMA Pediatr. 2016;170(2):173-4.

Study design,

Dependent variable

1211 Koster, E. S., Van der Ent, C. K.,Uiterwaal, C. S., Verheij, T. J.,Raaijmakers, J. A.,Maitland-van der Zee, A. H. Asthma medication use in infancy: determinants related to prescription of drug therapy. Fam Pract. 2011;28(4):377-84

1212 Krabbendam, L.,Bakker, E.,Hornstra, G.,van Os, J. Relationship between DHA status at birth and child problem behaviour at 7 years of age. Prostaglandins Leukot Essent Fatty Acids. 2007;76(1):29-34.

1213 Kramer, M. S. Do breast-feeding and delayed introduction of solid foods protect against subsequent obesity?. J Pediatr. 1981;98(6):883-7.

1214 Kramer, M. S. Infant feeding, infection, and public health. Pediatrics. 1988;81(1):164-6

Independent variable

Included for systematic reviews not completed

\section{Included for}

systematic reviews not

completed

Study design

Included for

systematic reviews not completed 
1217 Kramer, M. S.,Barr, R. G.,Pless, I. B. Determinants of weight and adiposity in early childhood. Canadian Journal of Public Health. 1986;77(SUPPL. 1):98-103.

Included for systematic reviews not completed

1218 Kramer, M. S.,Fombonne, E., Igumnov, S., Vanilovich, I.,Matush, L., Mironova, E.,Bogdanovich, N., Tremblay, R. E.,Chalmers, B.,Zhang, X.,Platt, R. W. Effects of prolonged and exclusive breastfeeding on child behavior and maternal adjustment: evidence from a large, randomized trial. Pediatrics. 2008;121(3):e435-40.

Included for systematic reviews not completed

1219 Kramer, M. S.,Fombonne, E.,Matush, L.,Bogdanovich, N.,Dahhou, M.,Platt, R. W. Long-term behavioural consequences of infant feeding: the limits of observational studies. Paediatr Perinat Epidemiol. 2011;25(6):500-6.

Included for systematic reviews not completed

1220 Kramer, M. S.,Guo, T.,Platt, R. W.,Sevkovskaya, Z.,Dzikovich, I.,Collet, J. P.,Shapiro, S.,Chalmers, B.,Hodnett, E.,Vanilovich, I.,Mezen, Included for I.,Ducruet, T.,Shishko, G.,Bogdanovich, N. Infant growth and health outcomes associated with 3 compared with 6 mo of exclusive breastfeeding. Am J Clin Nutr. 2003;78(2):291-5.

completed

1221 Kramer, M. S.,Guo, T.,Platt, R. W.,Shapiro, S.,Collet, J. P.,Chalmers, B.,Hodnett, E.,Sevkovskaya, Z.,Dzikovich, I.,Vanilovich, I. Breastfeeding and infant growth: biology or bias?. Pediatrics. 2002;110(2 Pt 1):343-7.

Included for

systematic reviews not completed

1222 Kramer, M. S.,Guo, T.,Platt, R. W.,Vanilovich, I.,Sevkovskaya, Z.,Dzikovich, I.,Michaelsen, K. F.,Dewey, K. Feeding effects on growth during Independent variable infancy. J Pediatr. 2004;145(5):600-5.

1223 Kramer, M. S.,Martin, R. M.,Bogdanovich, N.,Vilchuk, K.,Dahhou, M.,Oken, E. Is restricted fetal growth associated with later adiposity? Observational analysis of a randomized trial. Am J Clin Nutr. 2014;100(1):176-81.

1224 Kramer, M. S.,Matush, L.,Aboud, F.,Vanilovich, I.,Bogdanovich, N.,Mironova, E. Long-term child health effects of breastfeeding in developed countries: new evidence from the PROBIT trial [abstract]. Journal of human lactation. 2007;23(1):90.

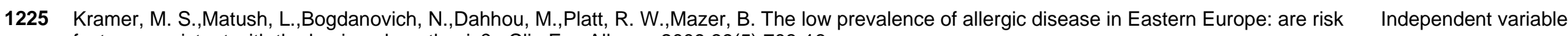
factors consistent with the hygiene hypothesis?. Clin Exp Allergy. 2009;39(5):708-16.

1226 Kramer, M. S.,Matush, L.,Vanilovich, I.,Platt, R. W.,Bogdanovich, N.,Sevkovskaya, Z.,Dzikovich, I.,Shishko, G.,Collet, J. P.,Martin, R. M.,Smith, G. D., Gillman, M. W.,Chalmers, B.,Hodnett, E., Shapiro, S. A randomized breast-feeding promotion intervention did not reduce child obesity in Belarus. J Nutr. 2009;139(2):417S-21S.

1227 Kramer, M. S.,Moodie, E. E.,Dahhou, M.,Platt, R. W. Breastfeeding and infant size: evidence of reverse causality. Am J Epidemiol. Independent variable 2011;173(9):978-83

1228 Kramer, M. S.,Moodie, E. E.,Platt, R. W. Infant feeding and growth: can we answer the causal question?. Epidemiology. 2012;23(6):790-4. Study design 
1229 Kramer, M. S.,Moroz, B. Do breast-feeding and delayed introduction of solid foods protect against subsequent atopic eczema?. J Pediatr. 1981;98(4):546-50

1230 Kramer, M. S.,Vanilovich, I.,Matush, L.,Bogdanovich, N.,Zhang, X.,Shishko, G.,Muller-Bolla, M.,Platt, R. W. The effect of prolonged and exclusive breast-feeding on dental caries in early school-age children. New evidence from a large randomized trial. Caries Res. 2007;41(6):4848.

1231 Kramer, M.,Matush, L.,Vanilovich, I.,Platt, R.,Mazer, B. Does breastfeeding help prevent asthma and allergy? Evidence from a randomized trial in Belarus. American journal of epidemiology. 2006;163(Suppl 11):S85.

1232 Kramer,M, S.,Matush,L,Vanilovich,I,Platt,R, W.,Bogdanovich,N,Sevkovskaya,Z,Dzikovich,I,Shishko,G,Collet,J, P.,Martin,R, M.,Davey, Smith,G,Gillman,M, W.,Chalmers,B,Hodnett,E,Shapiro,S,. Effects of prolonged and exclusive breastfeeding on child height, weight, adiposity, and blood pressure at age $6.5 \mathrm{y}$ : evidence from a large randomized trial. Am J Clin Nutr. 2007;86(6):1717-21.

1233 Kraus, J. F.,Greenland, S.,Bulterys, M. Risk factors for sudden infant death syndrome in the US Collaborative Perinatal Project. Int J Epidemiol. $1989 ; 18(1): 113-20$

1234 Kravetz, R. E. Infant nursing bottle. Am J Gastroenterol. 2003;98(7):1640.

systematic reviews not completed

Study design,

Dependent variable

1235 Krebs, N. F.,Hambidge, K. M.,Westcott, J. E.,Miller, L. V.,Sian, L.,Bell, M.,Grunwald, G. Exchangeable zinc pool size in infants is related to key variables of zinc homeostasis. J Nutr. 2003;133(5 Suppl 1):1498S-501S.

1236 Krebs, N. F.,Reidinger, C. J.,Robertson, A. D.,Hambidge, K. M. Growth and intakes of energy and zinc in infants fed human milk. J Pediatr. $1994 ; 124(1): 32-9$

1237 Krebs, N. F.,Reidinger, C.,Westcott, J.,Miller, L. V.,Fennessey, P. V.,Hambidge, K. M. Whole body zinc metabolism in full-term breasted and formula fed infants. Adv Exp Med Biol. 1994;352:223-6.

1238 Krebs, N. F.,Westcott, J. E.,Culbertson, D. L.,Sian, L.,Miller, L. V.,Hambidge, K. M. Comparison of complementary feeding strategies to meet zinc requirements of older breastfed infants. Am J Clin Nutr. 2012;96(1):30-5

1239 Krenz-Niedbala, M.,Puch, E. A.,Koscinski, K. Season of birth and subsequent body size: the potential role of prenatal vitamin D. Am J Hum Biol. Study design 2011;23(2):190-200

1240 Krishna, L. M. Breast feeding and development. Public Health. 1980;94(1):21-4.

Study design

1241 Krous, H. F.,Chadwick, A. E.,Stanley, C. Delayed infant death following catastrophic deterioration during breast-feeding. J Paediatr Child Health. Study design 2005;41(4):215-7.

1242 Kucukcongar A,Oguz A,Pinarli FG,Karadeniz C,Okur A,Kaya Z,Celik B. Breastfeeding and Childhood Cancer: Is Breastfeeding Preventative to Childhood Cancer?. Pediatr Hematol Oncol. 2015;32:374-81.

1243 Küçükçongar, A.,Ołuz, A.,Pinarli, F. G.,Karadeniz, C.,Okur, A.,Kaya, Z.,Çelik, B. Breastfeeding and Childhood Cancer: Is Breastfeeding Preventative to Childhood Cancer?. Pediatric Hematology and Oncology. 2015;32(6):374-381. 
1244 Kucur, C.,Simsek, E.,Kuduban, O.,Ozbay, I. Prevalence of and risk factors for otitis media with effusion in primary school children: case control study in Erzurum, Turkey. Turk J Pediatr. 2015;57(3):230-5.

1245 Kuhn, T.,Kroke, A.,Remer, T.,Schonau, E.,Buyken, A. E. Is breastfeeding related to bone properties? A longitudinal analysis of associations between breastfeeding duration and pQCT parameters in children and adolescents. Matern Child Nutr. 2014;10(4):642-9.

1246 Kuhnisch, J.,Mach, D.,Thiering, E.,Brockow, I.,Hoffmann, U.,Neumann, C.,Heinrich-Weltzien, R.,Bauer, C. P.,Berdel, D.,von Berg, A.,Koletzko, S.,Garcia-Godoy, F.,Hickel, R.,Heinrich, J. Respiratory diseases are associated with molar-incisor hypomineralizations. Swiss Dent J. 2014;124(3):286-93.

1247 Kuiper, S.,Muris, J. W.,Dompeling, E.,Kester, A. D.,Wesseling, G.,Knottnerus, J. A.,van Schayck, C. P. Interactive effect of family history and environmental factors on respiratory tract-related morbidity in infancy. J Allergy Clin Immunol. 2007;120(2):388-95.

1248 Kukkonen, A. K.,Savilahti, E. M.,Haahtela, T.,Savilahti, E.,Kuitunen, M. Ovalbumin-specific immunoglobulins A and G levels at age 2 years are associated with the occurrence of atopic disorders. Clin Exp Allergy. 2011;41(10):1414-21.

1249 Kull, I.,Bohme, M.,Wahlgren, C. F.,Nordvall, L.,Pershagen, G.,Wickman, M. Breast-feeding reduces the risk for childhood eczema. J Allergy Clin Immunol. 2005;116(3):657-61.

1250 Kull, I.,Melen, E.,Alm, J.,Hallberg, J.,Svartengren, M.,van Hage, M.,Pershagen, G.,Wickman, M.,Bergstrom, A. Breast-feeding in relation to asthma, lung function, and sensitization in young schoolchildren. J Allergy Clin Immunol. 2010;125(5):1013-9.

1251 Kumar, A. Breast feeding versus bottle feeding. J Indian Med Assoc. 1985;83(10):365-6.

1252 Kumar, V.,Sharma, S.,Khanna, P.,Vanaja, K. Breast vs bottle feeding-impact on growth in urban infants. Indian J Pediatr. 1981;48(392):271-5.

1253 Kumari, S.,Jain, P.,Arora, U.,Pruthi, R. K. Growth of breast fed infants. A longitudinal study. Indian Pediatr. 1982;19(12):963-8.

1254 Kumari, S.,Pruthi, P. K.,Mehra, R.,Sehgal, H. Breast feeding: physical growth during infancy. Indian J Pediatr. 1985;52(414):73-7.

1255 Kuperberg, K.,Evers, S. Feeding patterns and weight among First Nations children. Can J Diet Pract Res. 2006;67(2):79-84.

1256 Kupers, L. K.,L'Abee, C.,Bocca, G.,Stolk, R. P.,Sauer, P. J.,Corpeleijn, E. Determinants of Weight Gain during the First Two Years of Life--The GECKO Drenthe Birth Cohort. PLoS One. 2015;10(7):e0133326.

1257 Kuriakose, J. R. Nutritional status and feeding practices of infants. Nurs J India. 2010;101(8):184-6.

systematic reviews not

1258 Kurugol, Z.,Coker, M.,Coker, C.,Egemen, A.,Ersoz, B. Comparison of growth, serum prealbumin, transferrin, IgG and amino acids of term infants Group size fed breast mild or formula. Turk J Pediatr. 1997;39(2):195-202.

1259 Kurugol, Z.,Geylani, S.,Karaca, Y.,Umay, F.,Erensoy, S., Vardar, F.,Bak, M.,Yaprak, I.,Ozkinay, F.,Ozkinay, C. Rotavirus gastroenteritis among children under five years of age in Izmir, Turkey. Turk J Pediatr. 2003;45(4):290-4.
Independent variable

Study design

Country

Country

Country

Independent variable

Included for completed

Country

design

Independent variable

uded for completed

cluded for completed

ndependent variable

Independent variable

Health status 
1260 Kurugöl, Z.,Geylani, S.,Karaca, Y.,Umay, F.,Erensoy, S.,Vardar, F.,Bak, M.,Yaprak, I.,Özkinay, F.,Özkinay, C. Rotavirus gastroenteritis among children under five years of age in Izmir, Turkey. Turkish Journal of Pediatrics. 2003;45(4):290-294.

1261 Kurukulaaratchy, R. J.,Matthews, S.,Arshad, S. H. Relationship between childhood atopy and wheeze: what mediates wheezing in atopic phenotypes?. Ann Allergy Asthma Immunol. 2006;97(1):84-91.

1262 Kurzewski, K.,Gardner, J. M. Breastfeeding patterns among six-week-old term infants at the University Hospital of the West Indies. West Indian Med J. 2005;54(1):28-33.

1263 Kusunoki, T.,Morimoto, T.,Nishikomori, R.,Yasumi, T.,Heike, T.,Mukaida, K.,Fujii, T.,Nakahata, T. Breastfeeding and the prevalence of allergic diseases in schoolchildren: Does reverse causation matter?. Pediatric Allergy and Immunology. 2010;21(1 PART I):60-66.

1264 Kuyucu, S.,Saraclar, Y.,Tuncer, A.,Sackesen, C.,Adalioglu, G.,Sumbuloglu, V.,Sekerel, B. E. Determinants of atopic sensitization in Turkish school children: effects of pre- and post-natal events and maternal atopy. Pediatr Allergy Immunol. 2004;15(1):62-71.

1265 Kvaavik, E.,Tell, G. S., Klepp, K. I. Surveys of Norwegian youth indicated that breast feeding reduced subsequent risk of obesity. J Clin Epidemiol. 2005;58(8):849-55.

1266 Kwok, M. K.,Leung, G. M.,Schooling, C. M. Breast feeding and early adolescent behaviour, self-esteem and depression: Hong Kong's 'Children of 1997' birth cohort. Arch Dis Child. 2013;98(11):887-94.

1267 Kwok, M. K.,Schooling, C. M.,Lam, T. H.,Leung, G. M. Does breastfeeding protect against childhood overweight? Hong Kong's 'Children of 1997' birth cohort. Int J Epidemiol. 2010;39(1):297-305.

1268 Labayen, I.,Ortega, F. B.,Ruiz, J. R.,Rodriguez, G.,Jiménez-Pavón, D.,España-Romero, V.,Widhalm, K.,Gottrand, F.,Moreno, L. A. Breastfeeding attenuates the effect of low birthweight on abdominal adiposity in adolescents: The HELENA study. Maternal and Child Nutrition. 2015;11(4):1036-1040.

1269 Labayen, I.,Ruiz, J. R.,Ortega, F. B.,Loit, H. M.,Harro, J.,Villa, I.,Veidebaum, T.,Sjostrom, M. Exclusive breastfeeding duration and cardiorespiratory fitness in children and adolescents. Am J Clin Nutr. 2012;95(2):498-505.

\begin{tabular}{|c|c|c|}
\hline 1270 & Labbok, M. H. Consequences of breast-feeding for mother and child. J Biosoc Sci Suppl. 1985;9:43-54. & Study design \\
\hline 1271 & Ladd GA. Merlin's molars. Cal. 1986;49:14-5, 31. & Study design \\
\hline 1272 & Laditan, A. A. Bilateral genu vara in childhood. Cent Afr J Med. 1983;29(11):219-23. & $\begin{array}{l}\text { Dependent variable, } \\
\text { Country }\end{array}$ \\
\hline 1273 & $\begin{array}{l}\text { Ladomenou, F.,Kafatos, A., Galanakis, E. Environmental tobacco smoke exposure as a risk factor for infections in infancy. Acta Paediatr. } \\
\text { 2009;98(7):1137-41. }\end{array}$ & Independent variable \\
\hline
\end{tabular}

Study design

Independent variable

Independent variable

Study design

Study design

Study design

Included for

systematic reviews not completed

Included for systematic reviews not completed

Included for systematic reviews not completed

Study design

Study design

(1)

Dependent variable,

Independent variable 
1275 Ladomenou, F.,Moschandreas, J.,Kafatos, A., Tselentis, Y.,Galanakis, E. Protective effect of exclusive breastfeeding against infections during infancy: a prospective study. Arch Dis Child. 2010;95(12):1004-8.

1276 Lakhani SA,Chaudhri T,Jansen AA. Human milk and milk formulas for infant feeding. East Afr Med J. 1983;60:181-5.

1277 Lakshman, R.,Whittle, F.,Hardeman, W.,Suhrcke, M.,Wilson, E., Griffin, S.,Ong, K. K. Effectiveness of a behavioural intervention to prevent excessive weight gain during infancy (The Baby Milk Trial): study protocol for a randomised controlled trial. Trials. 2015;16(1):442.

1278 Lamb, M. M.,Dabelea, D.,Yin, X.,Ogden, L. G.,Klingensmith, G. J.,Rewers, M.,Norris, J. M. Early-life predictors of higher body mass index in healthy children. Ann Nutr Metab. 2010;56(1):16-22.

1279 Lamb, M. M.,Simpson, M. D.,Seifert, J.,Scott, F. W.,Rewers, M.,Norris, J. M. The association between IgG4 antibodies to dietary factors, islet autoimmunity and type 1 diabetes: the Diabetes Autoimmunity Study in the Young. PLoS One. 2013;8(2):e57936.

1280 Lamichhane, A. P.,Crandell, J. L.,Jaacks, L. M.,Couch, S. C.,Lawrence, J. M.,Mayer-Davis, E. J. Longitudinal associations of nutritional factors with glycated hemoglobin in youth with type 1 diabetes: the SEARCH Nutrition Ancillary Study. Am J Clin Nutr. 2015;101(6):1278-85.

1281 Lanari, M.,Adorni, F.,Silvestri, M.,Coscia, A.,Musicco, M. The multicenter Italian birth cohort study on incidence and determinants of lower respiratory tract infection hospitalization in infants at 33 weeks GA or more: preliminary results. Early Hum Dev. 2011;87 Suppl 1:S43-6.

1282 Lanari, M.,Prinelli, F.,Adorni, F.,Di Santo, S.,Faldella, G.,Silvestri, M.,Musicco, M. Maternal milk protects infants against bronchiolitis during the first year of life. Results from an Italian cohort of newborns. Early Hum Dev. 2013;89 Suppl 1:S51-7.

1283 Lanari, M.,Prinelli, F.,Adorni, F.,Di Santo, S.,Vandini, S.,Silvestri, M.,Musicco, M. Risk factors for bronchiolitis hospitalization during the first year of life in a multicenter Italian birth cohort. Ital J Pediatr. 2015;41:40.

1284 Lancashire, R. J.,Sorahan, T. Breastfeeding and childhood cancer risks: OSCC data. Br J Cancer. 2003;88(7):1035-7.

Included for systematic reviews not completed

Study design

Study design,

Independent variable

Included for

systematic reviews not completed

Dependent variable

Dependent variable,

Health status

Independent variable

Included for systematic reviews not completed

Included for systematic reviews not completed

Dependent variable

1285 Landaas, S.,Skrede, S.,Steen, J. A. The levels of serum enzymes, plasma proteins and lipids in normal infants and small children. J Clin Chem Study design Clin Biochem. 1981;19(10):1075-80.

1286 Lande, B.,Andersen, L. F.,Henriksen, T.,Baerug, A.,Johansson, L.,Trygg, K. U.,Bjorneboe, G. E.,Veierod, M. B. Relations between high ponderal index at birth, feeding practices and body mass index in infancy. Eur J Clin Nutr. 2005;59(11):1241-9.

1287 Lane, B. J.,Sellen, V. Bottle caries: a nursing responsibility. Can J Public Health. 1986;77(2):128-30.

ncluded for systematic reviews not completed

Study design

1288 Lane, D. M.,McConathy, W. J. Changes in the serum lipids and apolipoproteins in the first four weeks of life. Pediatr Res. 1986;20(4):332-7. 
1290 Langman, M. J. Can epidemiology help us prevent celiac disease?. Gastroenterology. 1986;90(2):489-91.

Study design

1291 Langnase, K.,Mast, M.,Danielzik, S.,Spethmann, C.,Muller, M. J. Socioeconomic gradients in body weight of German children reverse direction between the ages of 2 and 6 years. J Nutr. 2003;133(3):789-96.

Included for systematic reviews not completed

1292 Lanting, C. I.,Fidler, V.,Huisman, M.,Touwen, B. C.,Boersma, E. R. Neurological differences between 9-year-old children fed breast-milk or formula-milk as babies. Lancet. 1994;344(8933):1319-22.

1293 Lanting, C. I.,Patandin, S.,Weisglas-Kuperus, N.,Touwen, B. C.,Boersma, E. R. Breastfeeding and neurological outcome at 42 months. Acta Paediatr. 1998;87(12):1224-9.

Independent variable

Included for

systematic reviews not completed

1294 Laohaviranit L. Milk and health. J Med Assoc Thai. 1985;68:326-9.

Study design

1295 Lapinleimu, H.,Vukari, J.,Nunikoski, H.,Tuominen, J.,Ronnemaa, T.,Valimaki, I.,Marniemi, J.,Jokinen, E.,Ehnholm, C.,Simell, O. Impact of gender, apolipoprotein E phenotypes, and diet on serum lipids and lipoproteins in infancy. J Pediatr. 1997;131(6):825-32.

1296 Larsson, E. Sucking, chewing, and feeding habits and the development of crossbite: a longitudinal study of girls from birth to 3 years of age. Angle Orthod. 2001;71(2):116-9.

1297 Larsson, J.,Aurelius, G.,Nordberg, L.,Rydelius, P.,Zetterström, R. The role of cumulative observations in identifying children in need of health promotion..including commentary by Glascoe FP. Ambulatory Child Health. 1999;5(3):209-217 9p.

Group size

Independent variable

Included for

systematic reviews not completed

1298 Lasekan, J. B.,Ostrom, K. M.,Jacobs, J. R.,Blatter, M. M.,Ndife, L. I.,Gooch, lii W. M.,Cho, S. Growth of newborn, term infants fed soy formulas for 1 year. Clinical Pediatrics. 1999;38(10):563-571.

Included for

systematic reviews not completed

1299 Laskey, M. A.,de Bono, S.,Smith, E. C.,Prentice, A. Influence of birth weight and early diet on peripheral bone in premenopausal Cambridge women: a pQCT study. J Musculoskelet Neuronal Interact. 2007;7(1):83.

Study design

1300 Lau, Y. L.,Karlberg, J.,Yeung, C. Y. Prevalence of and factors associated with childhood asthma in Hong Kong. Acta Paediatr. 1995;84(7):820- Study design

1301 Laubereau, B.,Brockow, I.,Zirngibl, A.,Koletzko, S.,Gruebl, A., von Berg, A.,Filipiak-Pittroff, B.,Berdel, D.,Bauer, C. P.,Reinhardt, D.,Heinrich, J.,Wichmann, H. E. Effect of breast-feeding on the development of atopic dermatitis during the first 3 years of life--results from the GINI-birth Independent variable cohort study. J Pediatr. 2004;144(5):602-7.

1302 Lauer, J. A.,Betran, A. P.,Barros, A. J.,de Onis, M. Deaths and years of life lost due to suboptimal breast-feeding among children in the developing world: a global ecological risk assessment. Public Health Nutr. 2006;9(6):673-85. 
1304 Lauzon-Guillain, Bd,Wijndaele, K.,Clark, M.,Acerini, C. L.,Hughes, I. A.,Dunger, D. B.,Wells, J. C.,Ong, K. K. Breastfeeding and infant temperament at age three months. PLoS One. 2012;7(1):e29326.

1305 Lawlor, D. A.,Najman, J. M.,Batty, G. D.,O'Callaghan, M. J.,Williams, G. M.,Bor, W. Early life predictors of childhood intelligence: findings from the Mater-University study of pregnancy and its outcomes. Paediatr Perinat Epidemiol. 2006;20(2):148-62.

Included for

systematic reviews not completed

1306 Lawlor, D. A.,Najman, J. M.,Sterne, J.,Williams, G. M.,Ebrahim, S.,Davey Smith, G. Associations of parental, birth, and early life characteristics with systolic blood pressure at 5 years of age: findings from the Mater-University study of pregnancy and its outcomes. Circulation. 2004;110(16):2417-23

1307 Lawlor, D. A.,Riddoch, C. J.,Page, A. S.,Andersen, L. B.,Wedderkopp, N.,Harro, M.,Stansbie, D.,Smith, G. D. Infant feeding and components of the metabolic syndrome: findings from the European Youth Heart Study. Arch Dis Child. 2005;90(6):582-8.

1308 Lawrence, R. A. Breast-feeding trends: a cause for action. Pediatrics. 1991;88(4):867-8. Independent variable

1309 Lawrence, R. A. Can we expect greater intelligence from human milk feedings?. Birth. 1992;19(2):105-6. Study design

1310 Lawrence, R. A. Promotion of Breastfeeding Intervention Trial (PROBIT) a randomized trial in the Republic of Belarus. J Pediatr. 2001;139(1):164-5

1311 Layte, R.,Bennett, A.,McCrory, C.,Kearney, J. Social class variation in the predictors of rapid growth in infancy and obesity at age 3 years. Int J Obes (Lond). 2014;38(1):82-90.

1312 Lazerov, J.,Ervin, C. Promoting breastfeeding: breastfeeding and population health. Breastfeed Med. 2011;6:305-6.

Study design

Study design

Included for

systematic reviews not completed

1313 Leary SD, Lawlor DA, Davey Smith G, Brion MJ, Ness AR. Behavioural early-life exposures and body composition at age 15 years. Nutrition and Diabetes. 2015;5(2)e150.

Study design

Included for systematic reviews not completed

1314 Lee, B. Breastfeeding. J R Soc Med. 1995;88(9):537p-538p.

Study design

1315 Lee, H. A.,Kim, Y. J.,Lee, H.,Gwak, H. S.,Hong, Y. S.,Kim, H. S.,Park, E. A.,Cho, S. J.,Ha, E. H.,Park, H. The preventive effect of breast-feeding for longer than 6 months on early pubertal development among children aged 7-9 years in Korea. Public Health Nutr. $2015: 1-8$.

Included for systematic reviews not completed

Group size

1316 Lee, L. C.,Pratt, C. A.,DeLaski-Smith, D.,Karabenick, S. A. The growth patterns of American-born Chinese infants. Nutrition Research 1999;19(5):697-708.

1317 Leeson, C. P.,Kattenhorn, M.,Deanfield, J. E.,Lucas, A. Duration of breast feeding and arterial distensibility in early adult life: population based study. BMJ. 2001;322(7287):643-7.
Study design 
1320 Lenguerrand, E.,Harding, S. P46 Ethnic differences in pace of growth between birth and 5 years: results from the millennium cohort study. Journal of Epidemiology \& Community Health. 2010;64:A51-A51 1p.

1321 Leonard, W. R.,Dewalt, K. M.,Stansbury, J. P.,McCaston, M. K. Influence of dietary quality on the growth of highland and coastal Ecuadorian children. Am J Hum Biol. 2000;12(6):825-837.

Peer review

Included for

systematic reviews not completed

1322 Lerman, Y.,Slepon, R.,Cohen, D. Epidemiology of acute diarrheal diseases in children in a high standard of living rural settlement in Israel Pediatr Infect Dis J. 1994;13(2):116-22.

1323 Leung, E. Y.,Au, K. Y.,Cheng, S. S.,Kok, S. Y.,Lui, H. K.,Wong, W. C. Practice of breastfeeding and factors that affect breastfeeding in Hong Kong. Hong Kong Med J. 2006;12(6):432-6.

1324 Leung, G. M.,Lam, T. H.,Ho, L. M.,Lau, Y. L. Health consequences of breast-feeding: doctors' visits and hospitalizations during the first 18 months of life in Hong Kong Chinese infants. Epidemiology. 2005;16(3):328-35.

Study design

Dependent variable

Included for

systematic reviews not completed

1325 Leung, S. S. F.,Davies, D. P.,Lui, S.,Lo, L., Yuen, P.,Swaminathan, R. Iron deficiency is uncommon in healthy Hong Kong infants at 18 months. Journal of Tropical Pediatrics. 1988;34(3):100-103.

1326 Leung, S. S.,Peng, C. X.,Xu, Y. Y.,Liu, K. M.,Quan, X. J.,Lui, S.,Davies, D. P. Comparative study of growth of Chinese infants: Hong Kong versus Guangzhou. J Trop Pediatr. 1994;40(3):166-71.

1327 Leung, S.,Davies, D. P. Infant feeding and growth of Chinese infants: birth to 2 years. Paediatr Perinat Epidemiol. 1994;8(3):301-13.

Independent variable Dependent variable

Independent variable

1328 Leventakou, V.,Roumeliotaki, T.,Koutra, K.,Vassilaki, M.,Mantzouranis, E.,Bitsios, P.,Kogevinas, M.,Chatzi, L. Breastfeeding duration and cognitive, language and motor development at 18 months of age: Rhea mother-child cohort in Crete, Greece. J Epidemiol Community Health. 2015;69(3):232-9.

1329 Leventhal, J. M.,Shapiro, E. D.,Aten, C. B.,Berg, A. T.,Egerter, S. A. Does breast-feeding protect against infections in infants less than 3 months of age?. Pediatrics. 1986;78(5):896-903.

\section{Independent variable}

Included for

systematic reviews not completed

Included for systematic reviews not completed

1330 Lever, R. The role of food in atopic eczema. J Am Acad Dermatol. 2001;45(1 Suppl):S57-60.

Study design

1331 Levine, O. S.,Farley, M.,Harrison, L. H.,Lefkowitz, L.,McGeer, A.,Schwartz, B. Risk factors for invasive pneumococcal disease in children: a Study design population-based case-control study in North America. Pediatrics. 1999;103(3):E28.

1332 Lewando-Hundt, G.,Forman, M. R. Autonomy, access and care: a study of Palestinian Bedouin of the Negev of Israel. Social Sciences in 
1333 Lewis, J. K. Anderson M. Willeitner A. Powdered Versus Liquid Human Milk Fortifier: A Blinded, Randomized, Controlled Trial. Pediatric Academic Societies Annual Meeting. 2011.

1334 Lewis, S.,Butland, B.,Strachan, D.,Bynner, J.,Richards, D.,Butler, N.,Britton, J. Study of the aetiology of wheezing illness at age 16 in two national British birth cohorts. Thorax. 1996;51(7):670-6.

1335 L'Hoir, M. P.,Engelberts, A. C., van Well, G. T.,Damste, P. H.,Idema, N. K.,Westers, P.,Mellenbergh, G. J.,Wolters, W. H.,Huber, J. Dummy use, thumb sucking, mouth breathing and cot death. Eur J Pediatr. 1999;158(11):896-901.

1336 l'Hoir, M. P.,Engelberts, A. C.,van Well, G. T.,Westers, P.,Mellenbergh, G. J.,Wolters, W. H.,Huber, J. Case-control study of current validity of previously described risk factors for SIDS in The Netherlands. Arch Dis Child. 1998;79(5):386-93.

1337 Li, C.,Goran, M. I.,Kaur, H.,Nollen, N.,Ahluwalia, J. S. Developmental trajectories of overweight during childhood: role of early life factors Obesity (Silver Spring). 2007;15(3):760-71.

1338 Li, C.,Kaur, H.,Choi, W. S.,Huang, T. T.,Lee, R. E.,Ahluwalia, J. S. Additive interactions of maternal prepregnancy BMI and breast-feeding on childhood overweight. Obes Res. 2005;13(2):362-71.

$1339 \mathrm{Li}$, J.,Dykman, R. A., Jing, H.,Gilchrist, J. M.,Badger, T. M.,Pivik, R. T. Cortical responses to speech sounds in 3- and 6-month-old infants fed breast milk, milk formula, or soy formula. Dev Neuropsychol. 2010;35(6):762-84.

$1340 \mathrm{Li}, \mathrm{L} .$, Kleinman, K.,Gillman, M. W. A comparison of confounding adjustment methods with an application to early life determinants of childhood obesity. J Dev Orig Health Dis. 2014;5(6):435-47.

$1341 \mathrm{Li}, \mathrm{L} .$, Manor, O.,Power, C. Early environment and child-to-adult growth trajectories in the 1958 British birth cohort. Am J Clin Nutr. 2004;80(1):185-92

1342 Li, L.,Power, C. Influences on childhood height: comparing two generations in the 1958 British birth cohort. Int J Epidemiol. $2004 ; 33(6): 1320-8$.

$1343 \mathrm{Li}, \mathrm{N} .$, Strobino, D.,Ahmed, S.,Minkovitz, C. S. Is there a healthy foreign born effect for childhood obesity in the United States?. Matern Child Health J. 2011;15(3):310-23.

1344 Li, R.,Dee, D.,Li, C. M.,Hoffman, H. J.,Grummer-Strawn, L. M. Breastfeeding and risk of infections at 6 years. Pediatrics. 2014;134 Suppl 1:S13-

1345 Li, R.,Fein, S. B.,Grummer-Strawn, L. M. Association of breastfeeding intensity and bottle-emptying behaviors at early infancy with infants' risk for excess weight at late infancy. Pediatrics. 2008;122 Suppl 2:S77-84.
Peer review

Study design

Independent variable

Included for

systematic reviews not completed

Included for

systematic reviews not completed

Included for

systematic reviews not completed

Included for

systematic reviews not completed

Included for

systematic reviews not completed

Study design, Independent variable

Independent variable

Independent variable

\section{Included for}

systematic reviews not

completed

\section{Included for}

systematic reviews not completed

Included for

systematic reviews not completed 

Pediatrics. 2010;125(6):e1386-93.

1347 Li, R.,Magadia, J.,Fein, S. B.,Grummer-Strawn, L. M. Risk of bottle-feeding for rapid weight gain during the first year of life. Arch Pediatr Adolesc Med. 2012;166(5):431-6.

Dependent variable

Included for

systematic reviews not completed

1348 Li, S. C.,Kuo, S. C.,Hsu, Y. Y.,Lin, S. J.,Chen, P. C.,Chen, Y. C. Effect of Breastfeeding Duration on Infant Growth Until 18 Months of Age: A National Birth Cohort Study. Journal of Experimental and Clinical Medicine. 2010;2(4):165-172.

Included for

systematic reviews not completed

1349 Li, Y.,Navia, J. M.,Caufield, P. W. Colonization by mutans streptococci in the mouths of 3- and 4-year-old Chinese children with or without enamel hypoplasia. Arch Oral Biol. 1994;39(12):1057-62.

1350 Liao, S. L.,Lai, S. H.,Yeh, K. W.,Huang, Y. L., Yao, T. C.,Tsai, M. H.,Hua, M. C.,Huang, J. L.. Exclusive breastfeeding is associated with reduced cow's milk sensitization in early childhood. Pediatr Allergy Immunol. 2014;25(5):456-61.

1351 Libraty, D. H.,Capeding, R. Z.,Obcena, A.,Brion, J. D.,Tallo, V. Breastfeeding During Early Infancy is Associated with a Lower Incidence of Febrile Illnesses. Open Pediatr Med Journal. 2013;7:40-41.

1352 Liebrechts-Akkerman, G.,Lao, O.,Liu, F.,Van Sleuwen, B. E.,Engelberts, A. C.,L'Hoir, M. P.,Tiemeier, H. W.,Kayser, M. Postnatal parental smoking: An important risk factor for SIDS. European Journal of Pediatrics. 2011;170(10):1281-1291.

Study design

Dependent variable

Dependent variable,

Country

Included for

systematic reviews not completed

1353 Lima, A. A.,Moore, S. R.,Barboza, M. S., Jr.,Soares, A. M.,Schleupner, M. A.,Newman, R. D.,Sears, C. L.,Nataro, J. P.,Fedorko, D. P.,Wuhib, T.,Schorling, J. B.,Guerrant, R. L. Persistent diarrhea signals a critical period of increased diarrhea burdens and nutritional shortfalls: a prospective cohort study among children in northeastern Brazil. J Infect Dis. 2000;181(5):1643-51.

Included for

systematic reviews not completed

1354 Lin, H.,Sun, L.,Lin, J.,He, J.,Deng, A.,Kang, M.,Zeng, H.,Ma, W.,Zhang, Y. Protective effect of exclusive breastfeeding against hand, foot and mouth disease. BMC Infect Dis. 2014;14:645.

1355 Lind, J. N.,Li, R.,Perrine, C. G.,Schieve, L. A. Breastfeeding and later psychosocial development of children at 6 years of age. Pediatrics. 2014;134 Suppl 1:S36-41.

Study design,

Dependent variable

Included for

systematic reviews not completed

1356 Lindberg, S. M.,Adams, A. K.,Prince, R. J. Early predictors of obesity and cardiovascular risk among American Indian children. Matern Child Health J. 2012;16(9):1879-86.

Included for

systematic reviews not completed

1357 Lindenberg, C. S.,Artola, R. C.,Estrada, V. J. Determinants of early infant weaning: a multivariate approach. Int J Nurs Stud. 1990;27(1):35-41.

Country

1358 Lindfors, A. T.,Danielsson, L.,Enocksson, E.,Johansson, S. G.,Westin, S. Allergic symptoms up to 4-6 years of age in children given cow milk Independent variable neonatally. A prospective study. Allergy. 1992;47(3):207-11.

1359 Lindfors, A.,Enocksson, E. Development of atopic disease after early administration of cow milk formula. Allergy. 1988;43(1):11-6. Independent variable 
1360 Linhares Rda, S.,Gigante, D. P.,de Barros, F. C.,Horta, B. L. Carotid intima-media thickness at age 30, birth weight, accelerated growth during infancy and breastfeeding: a birth cohort study in Southern Brazil. PLoS One. 2015;10(1):e0115166.

1361 Linhares, A. C., Gabbay, Y. B.,Freitas, R. B.,da Rosa, E. S.,Mascarenhas, J. D.,Loureiro, E. C. Longitudinal study of rotavirus infections among children from Belem, Brazil. Epidemiol Infect. 1989;102(1):129-45.

Included for

systematic reviews not completed

Independent variable emphasize a different etiology. J Allergy Clin Immunol. 2006;117(1):184-9.

1363 Lionetti, E.,Castellaneta, S.,Francavilla, R.,Pulvirenti, A.,Tonutti, E.,Amarri, S.,Barbato, M.,Barbera, C.,Barera, G.,Bellantoni, A.,Castellano, E.,Limongelli, M. G.,Pellegrino, S.,Polloni, C.,Ughi, C.,Zuin, G.,Guariso, G.,Fasano, A.,Catassi, C. Infant feeding pattern, HLA status, and prevalence of celiac disease. Digestive and liver disease. 2014;46:e75-e76.

1364 Lionetti, E.,Castellaneta, S.,Pulvirenti, A.,Tonutti, E.,Francavilla, R.,Fasano, A.,Catassi, C. Prevalence and natural history of potential celiac disease in at-family-risk infants prospectively investigated from birth. J Pediatr. 2012;161(5):908-14

1365 Lipsman, S.,Dewey, K. G.,Lonnerdal, B. Breast-feeding among teenage mothers: milk composition, infant growth, and maternal dietary intake. J Group size Pediatr Gastroenterol Nutr. 1985;4(3):426-34.

1366 Litmanovitz, I.,Davidson, K.,Eliakim, A.,Regev, R. H.,Dolfin, T.,Arnon, S.,Bar-Yoseph, F.,Goren, A.,Lifshitz, Y.,Nemet, D. High Beta-palmitate formula and bone strength in term infants: a randomized, double-blind, controlled trial. Calcif Tissue Int. 2013;92(1):35-41.

1367 Little, R. E.,Lambert, M. D., 3rd,Worthington-Roberts, B.,Ervin, C. H. Maternal smoking during lactation: relation to infant size at one year of age. Am J Epidemiol. 1994;140(6):544-54

1368 Liu, J. Neglected problem: nursing bottle syndrome. Dentistry (Loma Linda). 1990;3(2):57-8. systematic reviews not completed

Study design

1369 Liu, J.,Leung, P.,Yang, A. Breastfeeding and active bonding protects against children's internalizing behavior problems. Nutrients. 2014;6(1):7689

1370 Liu, Y. Q.,Qian, Z.,Wang, J.,Lu, T.,Lin, S.,Zeng, X. W.,Liu, R. Q.,Zhu, Y.,Qin, X. D.,Yuan, P.,Zhou, Y.,Li, M.,Hao, Y. T.,Dong, G. H. Breastfeeding modifies the effects of environment tobacco smoke exposure on respiratory diseases and symptoms in Chinese children: the Seven Northeast Cities Study. Indoor Air. 2015.

1371 Livingstone, V. Failure to thrive while breastfeeding. Breastfeed Med. 2006;1(2):108-11

Study design

1372 Livny, A.,Assali, R.,Sgan-Cohen, H. D. Early Childhood Caries among a Bedouin community residing in the eastern outskirts of Jerusalem. BMC Study design Public Health. 2007;7:167.

1373 Lnnerdal, B.,Timby, N.,Domellf, M.,Domellf, E.,Hernell, O. Supplementation of infant formula with milk fat globule membranes improves cognitive Peer review performance and reduces infections in formula-fed infants. FASEB journal. 2014;28(1 suppl. 1).

1374 Lo, G. L. The use of comforters and dental caries in the Singaporean preschool children. Singapore Dent J. 1985;10(1):21-4. 
1375 Lodge, C. J.,Zaloumis, S.,Lowe, A. J.,Gurrin, L. C.,Matheson, M. C.,Axelrad, C.,Bennett, C. M.,Hill, D. J.,Hosking, C. S.,Svanes, C.,Abramson, M. J.,Allen, K. J.,Dharmage, S. C. Early-life risk factors for childhood wheeze phenotypes in a high-risk birth cohort. J Pediatr. 2014;164(2):28994 e1-2.

1376 Lodinova, R.,Jouja, V.,Vinsova, N.,Voce infants. Czech Med. 1980;3(1):47-58.

1377 Lodinova-Zadnikova, R.,Tlaskalova, H.,Bartakova, Z. The antibody response in infants after colonization of the intestine with E. coli O83. Artificial colonization used as a prevention against nosocomial infections. Adv Exp Med Biol. 1991;310:329-35.

1378 Loeb H,Mozin MJ. Prevention of chronic diarrhea: nutritional implications. J Pediatr Gastroenterol Nutr. 1983;2 Suppl 1:S328-34.

1379 Lombeck, I.,Fuchs, A. Zinc and copper in infants fed breast-milk or different formula. Eur J Pediatr. 1994;153(10):770-6

1380 Long, K. Z.,Wood, J. W.,Vasquez Gariby, E.,Weiss, K. M.,Mathewson, J. J.,de la Cabada, F. J.,DuPont, H. L.,Wilson, R. A. Proportional hazards analysis of diarrhea due to enterotoxigenic Escherichia coli and breast feeding in a cohort of urban Mexican children. Am $\mathrm{J}$ Epidemiol. 1994;139(2):193-205.

1381 Long, K.,Vasquez-Garibay, E.,Mathewson, J.,de la Cabada, J.,DuPont, H. The impact of infant feeding patterns on infection and diarrheal disease due to enterotoxigenic Escherichia coli. Salud Publica Mex. 1999;41(4):263-70.

1382 Long, S. A.,Bugg, K. Can't we all just get along?. J Hum Lact. 2015;31(1):29-31.

1383 Lonnerdal, B.,Chen, C. L. Effects of formula protein level and ratio on infant growth, plasma amino acids and serum trace elements. I. Cow's milk formula. Acta Paediatr Scand. 1990;79(3):257-65.

1384 Lonnerdal, B.,Havel, P. J. Serum leptin concentrations in infants: effects of diet, sex, and adiposity. Am J Clin Nutr. 2000;72(2):484-9.

1385 Lonnerdal, B.,Hernell, O. Effects of feeding ultrahigh-temperature (UHT)-treated infant formula with different protein concentrations or powdered formula, as compared with breast-feeding, on plasma amino acids, hematology, and trace element status. Am J Clin Nutr. 1998;68(2):350-6.

1386 Lonnerdal, B.,Hernell, O. Iron, zinc, copper and selenium status of breast-fed infants and infants fed trace element fortified milk-based infant formula. Acta Paediatr. 1994;83(4):367-73.

1387 Lonnerdal, B.,Kvistgaard, A. S.,Peerson, J. M.,Donovan, S. M.,Peng, Y. M. Growth, Nutrition and Cytokine Response of Breast-Fed Infants and Infants Fed Formula with Added Bovine Osteopontin. J Pediatr Gastroenterol Nutr. 2015.

1388 Lopez Bravo, I. M.,Sepulveda, H.,Valdes, I. Acute respiratory illnesses in the first 18 months of life. Rev Panam Salud Publica. 1997;1(1):9-17.
Study design

Dependent variable

Study design, Health status

Study design

Included for systematic reviews not completed

\section{Included for}

systematic reviews not completed

Independent variable

Study design

Included for

systematic reviews not completed

Independent variable

Included for

systematic reviews not completed

Independent variable

Included for

systematic reviews not completed

Included for

systematic reviews not completed 
1389 Lopez Bravo, I.,Cabiol, C.,Arcuch, S.,Rivera, E.,Vargas, S. Breast-feeding, weight gains, diarrhea, and malnutrition in the first year of life. Bull Pan Am Health Organ. 1984;18(2):151-63.
Included for systematic reviews not completed

Study design

Dependent variable

Dependent variable

1392 life. J Investig Allergol Clin Immunol. 1999;9(6):392-8.

1393 Lopez-Alarcon, M.,Villalpando, S.,Fajardo, A. Breast-feeding lowers the frequency and duration of acute respiratory infection and diarrhea in infants under six months of age. J Nutr. 1997;127(3):436-43.

1394 Losonsky, G. A.,D'Alessandra de Rimer, H. Rotavirus specific breast milk antibody in two populations and possible correlates of protection. Adv Exp Med Biol. 1991;310:265-9.

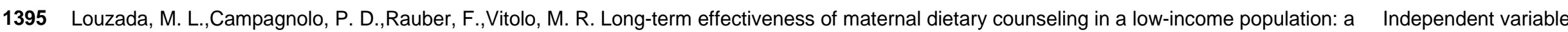
randomized field trial. Pediatrics. 2012;129(6):e1477-84.

1396 Lowe, A. J.,Carlin, J. B.,Bennett, C. M.,Abramson, M. J.,Hosking, C. S.,Hill, D. J.,Dharmage, S. C. Atopic disease and breast-feeding--cause or consequence?. J Allergy Clin Immunol. 2006;117(3):682-7.

1397 Lozoff, B.,Wolf, A. W.,Jimenez, E. Iron-deficiency anemia and infant development: effects of extended oral iron therapy. J Pediatr. $1996 ; 129(3): 382-9$

1398 Lu, R.,Costello, A. Failure to exclusively breastfeed and the risk of early infant mortality due to infectious disease in poor communities in Lima, Peru. J Trop Pediatr. 2000;46(5):309-11.

1399 Lubis, I. Z.,Sinuhaji, A. B.,Sebayang, T.,Lubis, M.,Barus, N.,Sutanto, A. H. Factors influencing the duration of infantile diarrhea. Paediatr Indones. 1985;25(9-10):175-89.

1400 Lucas, A.,Boyes, S.,Bloom, S. R.,Aynsley-Green, A. Metabolic and endocrine responses to a milk feed in six-day-old term infants: differences between breast and cow's milk formula feeding. Acta Paediatr Scand. 1981;70(2):195-200.

1401 Lucas, A.,Ewing, G.,Roberts, S. B.,Coward, W. A. How much energy does the breast fed infant consume and expend?. Br Med J (Clin Res Ed). $\quad$ Group size 1987;295(6590):75-7.

1402 Lucas, A.,Lockton, S.,Davies, P. S. Randomised trial of a ready-to-feed compared with powdered formula. Arch Dis Child. 1992;67(7):935-9.
Group size

systematic reviews not completed

Study design

Dependent variable

Independent variable

Included for

systematic reviews not completed

Included for

systematic reviews not completed

\section{Country}

Study design,

Dependent variable 
1403 Lucas, A.,Stafford, M.,Morley, R.,Abbott, R.,Stephenson, T.,MacFadyen, U.,Elias-Jones, A.,Clements, H. Efficacy and safety of long-chain polyunsaturated fatty acid supplementation of infant-formula milk: a randomised trial. Lancet. 1999;354(9194):1948-54.
Included for systematic reviews not completed

Independent variable

Dependent variable

Study design

Study design

Independent variable

Included for systematic reviews not completed

Study design

Group size

Study design

Study design

Included for systematic reviews not completed

1415 Luopajarvi, K.,Savilahti, E.,Virtanen, S. M.,Ilonen, J.,Knip, M.,Akerblom, H. K.,Vaarala, O. Enhanced levels of cow's milk antibodies in infancy in Group size children who develop type 1 diabetes later in childhood. Pediatr Diabetes. 2008;9(5):434-41.

1416 Lutter, C. K. Breastfeeding promotion--is its effectiveness supported by scientific evidence and global changes in breastfeeding behaviors?. Adv Study design Exp Med Biol. 2000;478:355-68.

1417 Lyall, J. Growing problems. Nurs Times. 1991;87(24):22-3.
Study design 
1418 Ma, D. Q.,Jones, G. Clinical risk factors but not bone density are associated with prevalent fractures in prepubertal children. J Paediatr Child Health. 2002;38(5):497-500.

1419 Ma, J. Q.,Zhou, L. L.,Hu, Y. Q.,Liu, J. R.,Liu, S. S.,Zhang, J.,Sheng, X. Y. A summary index of infant and child feeding practices is associated with child growth in urban Shanghai. BMC Public Health. 2012;12:568.

1420 MacDonald, L. D.,Gibson, R. S.,Miles, J. E. Changes in hair zinc and copper concentrations of breast fed and bottle fed infants during the first six months. Acta Paediatr Scand. 1982;71(5):785-9.

1421 Macdonald, P. D.,Ross, S. R.,Grant, L.,Young, D. Neonatal weight loss in breast and formula fed infants. Arch Dis Child Fetal Neonatal Ed. 2003;88(6):F472-6.

1422 Maclntyre, E. A.,Karr, C. J.,Koehoorn, M.,Demers, P.,Tamburic, L.,Lencar, C.,Brauer, M. Otitis media incidence and risk factors in a populationbased birth cohort. Paediatrics and Child Health. 2010;15(7):437-442.

1423 Macoun, E. The NSW Health Breastfeeding Project. N S W Public Health Bull. 2005;16(3-4):62.

1424 Madhavapeddi, R.,Ramachandran, P. Growth and morbidity of breastfed infants whose mothers were using combination pills. Breastfeeding Review. 1990;2(2):66-68 3p.

1425 Madhavapeddi, R.,Ramachandran, P. Growth of urban breastfed infants from low socio-economic group. J Trop Pediatr. 1993;39(6):328-31.

1426 Madsen, A. L.,Larnkjaer, A.,Molgaard, C.,Michaelsen, K. F. IGF-I and IGFBP-3 in healthy 9 month old infants from the SKOT cohort: breastfeeding, diet, and later obesity. Growth Horm IGF Res. 2011;21(4):199-204.

1427 Magalhaes, T. C.,Vieira, S. A.,Priore, S. E.,Ribeiro, A. Q.,Lamounier, J. A.,Franceschini, S. C.,Sant'Ana, L. F. Exclusive breastfeeding and other foods in the first six months of life: effects on nutritional status and body composition of Brazilian children. ScientificWorldJournal. 2012;2012:468581.

1428 Magana Cardenas, A.,Padilla Gonzalez, L. M.,Garcia de Alba, J. E.,Troyo San Roman, R.,Delgado Becerra, A. Some epidemiological aspects of maternal breast-feeding in a population entitled to social welfare services in Mexico. Bull Pan Am Health Organ. 1981;15(2):139-47.

1429 Magnus, M. C.,DeRoo, L. A.,Haberg, S. E.,Magnus, P.,Nafstad, P.,Nystad, W.,London, S. J. Prospective study of maternal alcohol intake during pregnancy or lactation and risk of childhood asthma: the Norwegian Mother and Child Cohort Study. Alcohol Clin Exp Res. 2014;38(4):1002-11.

1430 Magnusson, C. G. Cord serum IgE in relation to family history and as predictor of atopic disease in early infancy. Allergy. 1988;43(4):241-51.

\section{Study design,}

1431 Mai, X. M.,Becker, A. B.,Sellers, E. A.,Liem, J. J.,Kozyrskyj, A. L. The relationship of breast-feeding, overweight, and asthma in preadolescents. J Allergy Clin Immunol. 2007;120(3):551-6.

1432 Maisels, M. J.,Gifford, K. Breast-feeding, weight loss, and jaundice. J Pediatr. 1983;102(1):117-8.
Dependent variable systematic reviews not completed

Group size

Included for

systematic reviews not completed

Included for

systematic reviews not completed

Study design

Country

Country

Study design, Independent variable

Included for

systematic reviews not completed

Dependent variable

ndependent variable

Independent variable Independent variable 
1433 Majeed, R.,Rajar, U. D.,Shaikh, N.,Majeed, F.,Arain, A. A. Risk factors associated with childhood asthma. J Coll Physicians Surg Pak. 2008;18(5):299-302.

1434 Majorana, A.,Cagetti, M. G.,Bardellini, E.,Amadori, F.,Conti, G.,Strohmenger, L.,Campus, G. Feeding and smoking habits as cumulative risk factors for early childhood caries in toddlers, after adjustment for several behavioral determinants: a retrospective study. BMC Pediatr.

Included for $2014 ; 14: 45$.

systematic reviews not completed

1435 Makela, J.,Linderborg, K.,Niinikoski, H.,Yang, B.,Lagstrom, H. Breast milk fatty acid composition differs between overweight and normal weight women: the STEPS Study. Eur J Nutr. 2013;52(2):727-35.

1436 Mäkelä, J.,Vaarno, J.,Kaljonen, A.,Niinikoski, H.,Lagström, H. Maternal overweight impacts infant feeding patterns - The STEPS Study. European Journal of Clinical Nutrition. 2014;68(1):43-49.

Independent variable Dependent variable

Included for

systematic reviews not completed

1437 Makela, J.,Vaarno, J.,Kaljonen, A.,Niinikoski, H.,Lagstrom, H. Maternal overweight impacts infant feeding patterns--the STEPS Study. Eur J Clin Duplicate Nutr. 2014;68(1):43-9.

1438 Maki, M.,Kallonen, K.,Lahdeaho, M. L., Visakorpi, J. K. Changing pattern of childhood coeliac disease in Finland. Acta Paediatr Scand. $1988 ; 77(3): 408-12$.

1439 Makrides, M. Outcomes for mothers and their babies: do n-3 long-chain polyunsaturated fatty acids and seafoods make a difference?. J Am Diet Study design Assoc. 2008;108(10):1622-6.

1440 Makrides, M.,Gibson, R. A.,Simmer, K. The effect of dietary fat on the developing brain. J Paediatr Child Health. 1993;29(6):409-10.

Study design

1441 Makrides, M.,Hawkes, J. S.,Neumann, M. A.,Gibson, R. A. Nutritional effect of including egg yolk in the weaning diet of breast-fed and formulafed infants: a randomized controlled trial. Am J Clin Nutr. 2002;75(6):1084-92.

1442 Makrides, M.,Neumann, M. A.,Jeffrey, B.,Lien, E. L.,Gibson, R. A. A randomized trial of different ratios of linoleic to alpha-linolenic acid in the diet of term infants: effects on visual function and growth. Am J Clin Nutr. 2000;71(1):120-9.

Independent variable

Included for

systematic reviews not completed

1443 Makrides, M.,Neumann, M. A.,Simmer, K.,Gibson, R. A. A critical appraisal of the role of dietary long-chain polyunsaturated fatty acids on neural indices of term infants: a randomized, controlled trial. Pediatrics. 2000;105(1 Pt 1):32-8.

Included for systematic reviews not completed

1444 Makrides, M.,Neumann, M. A.,Simmer, K.,Gibson, R. A. Dietary long-chain polyunsaturated fatty acids do not influence growth of term infants: A randomized clinical trial. Pediatrics. 1999;104(3 Pt 1):468-75.

Included for systematic reviews not completed

1445 Makrides, M.,Neumann, M.,Gibson, R. Breast milk docosahexaenoic acid (DHA) and infant outcomes: a randomised clinical trial. Journal of

Peer review paediatrics and child health. 1997;33(4):A2

1446 Male, C.,Persson, L. A.,Freeman, V.,Guerra, A.,van't Hof, M. A.,Haschke, F. Prevalence of iron deficiency in 12-mo-old infants from 11 European areas and influence of dietary factors on iron status (Euro-Growth study). Acta Paediatr. 2001;90(5):492-8.

Included for systematic reviews not completed 
1448 Malinowska E,Kaczmarski M,Wasilewska J. Total IgE levels and skin test results in children under three years of age with food hypersensitivity. Med Sci Monit. 2002;8:Cr280-7.

1449 Mallol-Mesnard, N.,Menegaux, F.,Lacour, B.,Hartmann, O.,Frappaz, D.,Doz, F.,Bertozzi, A. I.,Chastagner, P.,Hemon, D.,Clavel, J. Birth characteristics and childhood malignant central nervous sytem tumors: the ESCALE study (French Society for Childhood Cancer). Cance Detect Prev. 2008;32(1):79-86.

1450 Malloy, M. H.,Berendes, H. Does breast-feeding influence intelligence quotients at 9 and 10 years of age?. Early Hum Dev. 1998;50(2):209-17.

1451 Malta AL. The Optimal Duration of Exclusive Breastfeeding for Physical Growth. Nutr Perspect. 2015;38(4):21-33.

1452 Manco, M.,Alterio, A.,Bugianesi, E.,Ciampalini, P.,Mariani, P.,Finocchi, M.,Agostoni, C.,Nobili, V. Insulin dynamics of breast- or formula-fed overweight and obese children. Journal of the American College of Nutrition. 2011;30(1):29-38.

1453 Mandel, E. M.,Doyle, W. J.,Winther, B.,Alper, C. M. The incidence, prevalence and burden of OM in unselected children aged 1-8 years followed by weekly otoscopy through the "common cold" season. Int J Pediatr Otorhinolaryngol. 2008;72(4):491-9.

1454 Mandhane, P. J.,Greene, J. M.,Sears, M. R. Interactions between breast-feeding, specific parental atopy, and sex on development of asthma and atopy. J Allergy Clin Immunol. 2007;119(6):1359-66.

1455 Mandic, Z.,Piricki, A. P.,Kenjeric, D.,Hanicar, B.,Tanasic, I. Breast vs. bottle: differences in the growth of Croatian infants. Matern Child Nutr. 2011;7(4):389-96.

1456 Mangskau, K. Baby bottle tooth decay: a problem affecting young children in North Dakota. Northwest Dent. 1991;70(6):25.

Study design,

Independent variable

Dependent variable

Study design,

Independent variable

Study design

Study design

Included for

systematic reviews not completed

Independent variable

Independent variable

Study design

Country infants during 0-1 year. Indian Pediatr. 1985;22(11):801-9.

1458 Maranhao, H. S.,Medeiros, M. C.,Scaletsky, I. C.,Fagundes-Neto, U.,Morais, M. B. The epidemiological and clinical characteristics and nutritional development of infants with acute diarrhoea, in north-eastern Brazil. Ann Trop Med Parasitol. 2008;102(4):357-65.

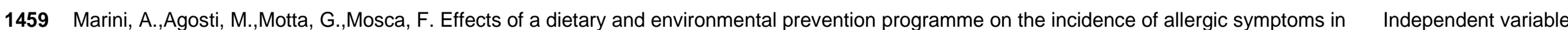
high atopic risk infants: three years' follow-up. Acta Paediatr Suppl. 1996;414:1-21.

1460 Marmot, M. G.,Page, C. M.,Atkins, E.,Douglas, J. W. Effect of breast-feeding on plasma cholesterol and weight in young adults. J Epidemiol Community Health. 1980;34(3):164-7.

1461 Marques, R. C.,Dorea, J. G.,Bernardi, J. V.,Bastos, W. R.,Malm, O. Maternal fish consumption in the nutrition transition of the Amazon Basin growth of exclusively breastfed infants during the first 5 years. Ann Hum Biol. 2008;35(4):363-77.
Independent variable

Included for systematic reviews not completed 
1462 Marques, R. C.,Dorea, J. G.,Bernardi, J. V.,Bastos, W. R.,Malm, O. Prenatal and postnatal mercury exposure, breastfeeding and neurodevelopment during the first 5 years. Cogn Behav Neurol. 2009;22(2):134-41.

1463 Marques, R. C.,Dorea, J. G.,Leao, R. S.,Dos Santos, V. G.,Bueno, L.,Marques, R. C.,Brandao, K. G.,Palermo, E. F.,Guimaraes, J. R. Role of methylmercury exposure (from fish consumption) on growth and neurodevelopment of children under 5 years of age living in a transitioning (tinmining) area of the western Amazon, Brazil. Arch Environ Contam Toxicol. 2012;62(2):341-50.

1464 Marques, R. F.,Taddei, J. A.,Lopez, F. A.,Braga, J. A. Breastfeeding exclusively and iron deficiency anemia during the first 6 months of age. Rev Assoc Med Bras. 2014;60(1):18-22.

1465 Marquis, G. S.,Habicht, J. P. Breastfeeding and stunting among toddlers in Peru. Adv Exp Med Biol. 2000;478:163-72.

1466 Marquis, G. S.,Habicht, J. P.,Lanata, C. F.,Black, R. E.,Rasmussen, K. M. Association of breastfeeding and stunting in Peruvian toddlers: an example of reverse causality. Int J Epidemiol. 1997;26(2):349-56.

1467 Marquis, G. S.,Habicht, J. P.,Lanata, C. F.,Black, R. E.,Rasmussen, K. M. Breast milk or animal-product foods improve linear growth of Peruvian toddlers consuming marginal diets. Am J Clin Nutr. 1997;66(5):1102-9.

1468 Marriage, B. J.,Buck, R. H.,Goehring, K. C., Oliver, J. S.,Williams, J. A. Infants Fed a Lower Calorie Formula With 2'FL Show Growth and 2'FL Uptake Like Breast-Fed Infants. J Pediatr Gastroenterol Nutr. 2015;61(6):649-58.

1469 Marshall, J. Infant feeding. 6. Formula feed. Pract Midwife. 2013;16(3):35-8.

1470 Martens, P. J.,Romphf, L. Factors associated with newborn in-hospital weight loss: comparisons by feeding method, demographics, and birthing procedures. J Hum Lact. 2007;23(3):233-41, quiz 242-5.

Included for

systematic reviews not completed

1471 Martin, A. J.,Landau, L. I.,Phelan, P. D. Natural history of allergy in asthmatic children followed to adult life. Med J Aust. 1981;2(9):470-4.

Study design

Independent variable

1472 Martin, R. M.,Ben-Shlomo, Y.,Gunnell, D.,Elwood, P.,Yarnell, J. W.,Davey Smith, G. Breast feeding and cardiovascular disease risk factors, incidence, and mortality: the Caerphilly study. J Epidemiol Community Health. 2005;59(2):121-9.

Study design

1473 Martin, R. M.,Ebrahim, S.,Griffin, M.,Davey Smith, G.,Nicolaides, A. N.,Georgiou, N.,Watson, S.,Frankel, S.,Holly, J. M.,Gunnell, D. Breastfeeding and atherosclerosis: intima-media thickness and plaques at 65-year follow-up of the Boyd Orr cohort. Arterioscler Thromb Vasc Biol. 2005;25(7):1482-8.

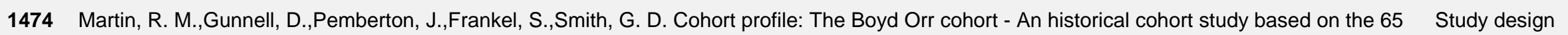
year follow-up of the Carnegie Survey of Diet and Health (1937-39). International Journal of Epidemiology. 2005;34(4):742-749.

1475 Martin, R. M.,Patel, R.,Kramer, M. S.,Guthrie, L., Vilchuck, K.,Bogdanovich, N.,Sergeichick, N.,Gusina, N.,Foo, Y.,Palmer, T.,Rifas-Shiman, S. L.,Gillman, M. W.,Smith, G. D.,Oken, E. Effects of promoting longer-term and exclusive breastfeeding on adiposity and insulin-like growth factorat age 11.5 years: a randomized trial. JAMA. 2013;309(10):1005-13. 
1476 Martin, R. M.,Smith, G. D.,Mangtani, P.,Frankel, S.,Gunnell, D. Association between breast feeding and growth: the Boyd-Orr cohort study. Arch Dis Child Fetal Neonatal Ed. 2002;87(3):F193-201.

1477 Martines, F.,Bentivegna, D.,Maira, E.,Sciacca, V.,Martines, E. Risk factors for otitis media with effusion: case-control study in Sicilian schoolchildren. Int J Pediatr Otorhinolaryngol. 2011;75(6):754-9.

1478 Martines, F.,Salvago, P.,Ferrara, S.,Messina, G.,Mucia, M.,Plescia, F.,Sireci, F. Factors influencing the development of otitis media among

Sicilian children affected by upper respiratory tract infections. Brazilian Journal of Otorhinolaryngology. 2015.

Study design

Study design

1479 Martines, J. C.,Ashworth, A.,Kirkwood, B. Breast-feeding among the urban poor in southern Brazil: reasons for termination in the first 6 months of life. Bull World Health Organ. 1989;67(2):151-61.

1480 Martines, J. C.,Habicht, J. P.,Ashworth, A.,Kirkwood, B. R. Weaning in southern Brazil: is there a "weanling's dilemma"?. J Nutr. 1994;124(8):1189-98.

1481 Martorell, A.,Plaza, A. M.,Boné, J.,Nevot, S.,García Ara Ma, C.,Echeverria, L.,Alonso, E.,Garde, J., Vila, B.,Alvaro, M.,Tauler, E.,Hernando, V.,Fernández, M. Cow's milk protein allergy. A multi-centre study: Clinical and epidemiological aspects. Allergologia et Immunopathologia. 2006;34(2):46-53.

1482 Martorell, R.,O'Gara, C. Breastfeeding, infant health, and socioeconomic status. Med Anthropol. 1985;9(2):173-81.

systematic reviews not completed

Dependent variable

Independent variable

Study design,

Independent variable

\section{Country}

1483 Mason, J. K.,Harkness, R. A.,Elton, R. A.,Bartholomew, S. Cot deaths in Edinburgh: infant feeding and socioeconomic factors. J Epidemiol Community Health. 1980;34(1):35-41.

1484 Massoni, A. C.,Chaves, A. M.,Rosenblatt, A.,Sampaio, F. C.,Oliveira, A. F. Prevalence of enamel defects related to pre-, peri- and postnatal factors in a Brazilian population. Community Dent Health. 2009;26(3):143-9.

1485 Mata, L. Cryptosporidium and other protozoa in diarrheal disease in less developed countries. Pediatr Infect Dis. 1986;5(1 Suppl):S117-30.

Study design, Independent variable

1486 Mata, L. Epidemiologic perspective of diarrheal disease in Costa Rica and current efforts in control, prevention, and research. Rev Latinoam Microbiol. 1981;23(2):109-19.

1487 Mata, L.,Bolanos, H.,Pizarro, D.,Vives, M. Cryptosporidiosis in children from some highland Costa Rican rural and urban areas. Am J Trop Med Hyg. 1984;33(1):24-9.

1488 Matee MI,Mikx FH,Maselle SY,Van Palenstein Helderman WH. Rampant caries and linear hypoplasia (short communication). Caries Res. 1992;26:205-8.

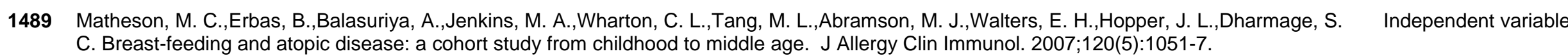

1490 Matsuda, I.,Higashi, A.,Ikeda, T.,Uehara, I.,Kuroki, Y. Effects of zinc and copper content of formulas on growth and on the concentration of zinc Group size and copper in serum and hair. J Pediatr Gastroenterol Nutr. 1984;3(3):421-5. 
1491 Matthews, M. K.,Webber, K.,McKim, E.,Banoub-Baddour, S.,Laryea, M. Infant feeding practices in Newfoundland and Labrador. Can J Public Health. 1995;86(5):296-300.

1492 Mattos-Graner, R. O.,Zelante, F.,Line, R. C.,Mayer, M. P. Association between caries prevalence and clinical, microbiological and dietary variables in 1.0 to 2.5-year-old Brazilian children. Caries Res. 1998;32(5):319-23.

1493 Maupome, G.,Karanja, N.,Ritenbaugh, C.,Lutz, T.,Aickin, M.,Becker, T. Dental caries in American Indian toddlers after a community-based beverage intervention. Ethn Dis. 2010;20(4):444-50.

1494 May, R.,Barber, J.,Simpson, T.,Winders, N.,Kuhler, K.,Schroeder, S. Growth pattern of overweight preschool children in the Siouxland WIC program. Am J Hum Biol. 2002;14(6):769-76.

1495 May, R.,Kim, D.Mote-Watson, D. Change in weight-for-length status during the first three months: relationships to birth weight and implications for metabolic risk. Am J Phys Anthropol. 2013;150(1):5-9.

1496 Mayer-Davis, E. J.,Dabelea, D.,Crandell, J. L.,Crume, T.,D'Agostino, R. B., Jr.,Dolan, L.,King, I. B.,Lawrence, J. M.,Norris, J. M.,Pihoker, C.,The, N. Nutritional factors and preservation of C-peptide in youth with recently diagnosed type 1 diabetes: SEARCH Nutrition Ancillary Study. Diabetes Care. 2013;36(7):1842-50.

1497 Mayer-Davis, E. J.,Rifas-Shiman, S. L.,Zhou, L.,Hu, F. B.,Colditz, G. A.,Gillman, M. W. Breast-feeding and risk for childhood obesity: does maternal diabetes or obesity status matter?. Diabetes Care. 2006;29(10):2231-7.

1498 McAllister, J. C.,Lane, A. T.,Buckingham, B. A. Vitamin D deficiency in the San Francisco Bay Area. J Pediatr Endocrinol Metab. 2006;19(3):205-8.

1499 McCann, M. F.,Moggia, A. V.,Higgins, J. E.,Potts, M.,Becker, C. The effects of a progestin-only oral contraceptive (levonorgestrel 0.03 mg) on breast-feeding. Contraception. 1989;40(6):635-48.

1500 McConnochie, K. M.,Roghmann, K. J. Breast feeding and maternal smoking as predictors of wheezing in children age 6 to 10 years. Pediatr Pulmonol. 1986;2(5):260-8.

1501 McCormick, D. P.,Grady, J. J.,Diego, A.,Matalon, R.,Revai, K.,Patel, J. A.,Han, Y.,Chonmaitree, T. Acute otitis media severity: association with cytokine gene polymorphisms and other risk factors. Int J Pediatr Otorhinolaryngol. 2011;75(5):708-12.

1502 McCrory, C.,Layte, R. Breastfeeding and risk of overweight and obesity at nine-years of age. Soc Sci Med. 2012;75(2):323-30.

1503 McCrory, C.,Murray, A. The effect of breastfeeding on neuro-development in infancy. Matern Child Health J. 2013;17(9):1680-8.

1504 McCusker, C. Teaching tolerance: Using the neonatal immune system to prevent allergic asthma. Expert Review of Clinical Immunology. 2008;4(4):429-432.

1505 McDougall, P.,Drewett, R. F.,Hungin, A. P. S.,Wright, C. M. The detection of early weight faltering at the 6-8-week check and its association with family factors, feeding and behavioural development. Archives of Disease in Childhood. 2009;94(7):549-552. systematic reviews not completed

Study design

Study design Dependent variable, Health status

Study design

Study design

Independent variable

Independent variable

Dependent variable

Study design

Included for systematic reviews not completed 
1506 McEnery, G.,Rao, K. P. The effectiveness of antenatal education of Pakistani and Indian women living in this country. Child Care Health Dev. 1986;12(6):385-99

1507 McIntosh, E. D.,De Silva, L. M.,Oates, R. K. Clinical severity of respiratory syncytial virus group A and B infection in Sydney, Australia. Pediat Infect Dis J. 1993;12(10):815-9.

1508 Mclsaac, K. E.,Moineddin, R.,Matheson, F. I. Breastfeeding as a means to prevent infant morbidity and mortality in Aboriginal Canadians: A population prevented fraction analysis. Can J Public Health. 2015;106(4):e217-22.

1509 McKinney, P. A.,Parslow, R.,Gurney, K. A.,Law, G. R.,Bodansky, H. J.,Williams, R. Perinatal and neonatal determinants of childhood type 1 diabetes. A case-control study in Yorkshire, U.K. Diabetes Care. 1999;22(6):928-32.

1510 McMichael, A. J. Widening the horizons of 'evidence': Nutrition and disease in ecological perspective. South African Journal of Clinical Nutrition. Study design 2005;18(2):140-148.

1511 McNamara, T. M.,Melnyk, B. M. The effect of food intake on atopic disease in high-risk infants and young children. Pediatric nursing 2000;26(6):602-604.

1512 McTeer, H. Fat, young, and poor: why breastfeeding is a critical weapon in the fight against childhood obesity. Breastfeed Med. 2012;7(5):325- Study design 6.

1513 Meador, K. J.,Baker, G. A.,Browning, N.,Clayton-Smith, J.,Combs-Cantrell, D. T.,Cohen, M.,Kalayjian, L. A.,Kanner, A.,Liporace, J. D.,Pennell, P. B.,Privitera, M.,Loring, D. W. Effects of breastfeeding in children of women taking antiepileptic drugs. Neurology. 2010;75(22):1954-60.

1514 Meador, K. J.,Baker, G. A.,Browning, N.,Cohen, M. J.,Bromley, R. L.,Clayton-Smith, J.,Kalayjian, L. A.,Kanner, A.,Liporace, J. D.,Pennell, P. B.,Privitera, M.,Loring, D. W. Breastfeeding in children of women taking antiepileptic drugs: cognitive outcomes at age 6 years. JAMA Pediatr. 2014;168(8):729-36.

1515 Meah, S. A breastfeeding intervention increased breast feeding and reduced GI tract infections and atopic eczema. Evidence Based Nursing 2001:106-106 1p.

1516 Megeid, F. Y. A.,Bakeit, Z. A. N.,Karim, B. O. I. A. A. Early introduction of cow's milk and short duration of breastfeeding is associated with increasing risk of juvenile diabetes. World Journal of Medical Sciences. 2011;6(2):54-60.

1517 Megraud, F.,Boudraa, G.,Bessaoud, K.,Bensid, S.,Dabis, F., Soltana, R.,Touhami, M. Incidence of Campylobacter infection in infants in western Study design Algeria and the possible protective role of breast feeding. Epidemiol Infect. 1990;105(1):73-8.

1518 Meinzen-Derr, J. K.,Guerrero, M. L.,Altaye, M.,Ortega-Gallegos, H.,Ruiz-Palacios, G. M.,Morrow, A. L. Risk of infant anemia is associated with exclusive breast-feeding and maternal anemia in a Mexican cohort. J Nutr. 2006;136(2):452-8.

1519 Meinzen-Derr, J. K.,Guerrero, M. L.,Altaye, M.,Ruiz-Palacios, G. M.,Morrow, A. L. Duration of exclusive breastfeeding and risk of anemia in a cohort of Mexican infants. Adv Exp Med Biol. 2004;554:395-8.

1520 Mellander, M.,Noren, J. G.,Freden, H.,Kjellmer, I. Mineralization defects in deciduous teeth of low birthweight infants. Acta Paediatr Scand. 1982;71(5):727-33

Independent variable

Included for

systematic reviews not completed

Study design

\section{Study design}

Independent variable

Peer review

Independent variable, Health status 
1522 Mendelson, M.,Cloutier, J.,Spence, L.,Sellers, E.,Taback, S.,Dean, H. Obesity and type 2 diabetes mellitus in a birth cohort of First Nation Independent variable children born to mothers with pediatric-onset type 2 diabetes. Pediatr Diabetes. 2011;12(3 Pt 2):219-28.

1523 Mendez, M. A., Torrent, M.,Julvez, J.,Ribas-Fito, N.,Kogevinas, M.,Sunyer, J. Maternal fish and other seafood intakes during pregnancy and child neurodevelopment at age 4 years. Public Health Nutr. 2009;12(10):1702-10.

Included for systematic reviews not completed

1524 Menihan, C. A.,Phipps, M.,Weitzen, S. Fetal heart rate patterns and sudden infant death syndrome. J Obstet Gynecol Neonatal Nurs. 2006;35(1):116-22.

1525 Merlob, P.,Aloni, R.,Prager, H.,Jelin, N.,Idel, M.,Kotona, J. Continued weight loss in the newborn during the third day of life as an indicator of early weaning. Israel Journal of Medical Sciences. 1994;30(8):646-648.

1526 Merlob, P.,Stahl, B.,Sulkes, J. Paroxetine during breast-feeding: infant weight gain and maternal adherence to counsel. Eur J Pediatr. 2004;163(3):135-9.

Independent variable

Independent variable Dependent variable

Included for systematic reviews not completed

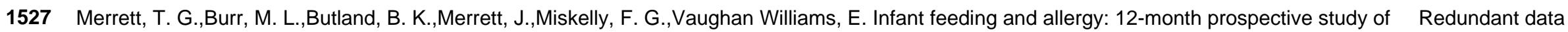
500 babies born into allergic families. Review 53 refs. Annals of allergy. 1988;61(6 (Pt 2)):13-20.

1528 Metcalfe, D. D. Food hypersensitivity. J Allergy Clin Immunol. 1984;73(6):749-62.

Study design, Independent variable

1529 Metzger, M. W.,McDade, T. W. Breastfeeding as obesity prevention in the United States: a sibling difference model. Am J Hum Biol. 2010;22(3):291-6.

Included for systematic reviews not completed

1530 Meyers, A.,Hertzberg, J. Bottle-feeding and malocclusion: is there an association?. Am J Orthod Dentofacial Orthop. $1988 ; 93(2): 149-52$.

Study design

1531 Micali, N.,Simonoff, E.,Treasure, J. Infant feeding and weight in the first year of life in babies of women with eating disorders. J Pediatr. 2009;154(1):55-60 e1.

Included for

systematic reviews not completed

1532 Michaelsen KF. 1.1 Child growth. World Rev Nutr Diet. 2015;113:1-5.

Peer review

1533 Michaelsen, K. F. 2.1 Breastfeeding. World Rev Nutr Diet. 2015;113:92-6.

Study design

1534 Michaelsen, K. F. Nutrition and growth during infancy. The Copenhagen Cohort Study. Acta Paediatr Suppl. 1997;420:1-36.

Included for systematic reviews not completed

1535 Michaelsen, K. F.,Larnkjaer, A.,Molgaard, C. Early diet, insulin-like growth factor-1, growth and later obesity. World Rev. Nutr. Diet. 2013;106:113-118.

Peer review 
1536 Michaelsen, K. F.,Petersen, S.,Greisen, G.,Thomsen, B. L. Weight, length, head circumference, and growth velocity in a longitudinal study of Danish infants. Dan Med Bull. 1994;41(5):577-85.

1537 Michels, K. B.,Willett, W. C.,Graubard, B. I.,Vaidya, R. L.,Cantwell, M. M.,Sansbury, L. B.,Forman, M. R. A longitudinal study of infant feeding and obesity throughout life course. Int J Obes (Lond). 2007;31(7):1078-85.

1538 Michie, C. A., Gilmour, J. Breast feeding and the risks of viral transmission. Arch Dis Child. 2001;84(5):381-2

1539 Michie, C. Breast feeding could reduce the risk of childhood leukaemias. Evid Based Nurs. 2016.

1540 Midodzi, W. K.,Rowe, B. H.,Majaesic, C. M.,Saunders, L. D.,Senthilselvan, A. Predictors for wheezing phenotypes in the first decade of life. Respirology. 2008;13(4):537-45.

1541 Midwinter, R. E.,Morris, A. F.,Colley, J. R. Infant feeding and atopy. Arch Dis Child. 1987;62(9):965-7.

1542 Mihrshahi, S.,Battistutta, D.,Magarey, A.,Daniels, L. A. Determinants of rapid weight gain during infancy: baseline results from the NOURISH randomised controlled trial. BMC Pediatr. 2011:11:99.

1543 Mikiel-Kostyra, K.,Mazur, J. Hospital policies and their influence on newborn body weight. Acta Paediatr. 1999;88(1):72-5.

1544 Milaat, W. A.,Elassouli, S. M. Epidemiology of diarrhoea in two major cities in Saudi Arabia. J Commun Dis. 1995;27(2):84-91.

1545 Milankov, O.,Bjelica, M.,Savic, R. What kind of milk can prevent infant's sideropenic anemia--comparative study. Med Pregl. 2014;67(5-6):167-

1546 Miliku, K.,Voortman, T.,Bakker, H.,Hofman, A.,Franco, O. H.,Jaddoe, V. W. Infant Breastfeeding and Kidney Function in School-Aged Children. Am J Kidney Dis. 2015;66(3):421-8.

1547 Miljanovic, O.,Cikota-Aleksic, B.,Likic, D.,Vojvodic, D.,Jovicevic, O.,Magic, Z. Association of cytokine gene polymorphisms and risk factors with otitis media proneness in children. Eur J Pediatr. 2016

1548 Millard, A. V.,Graham, M. A. Abrupt weaning reconsidered: evidence from central Mexico. J Trop Pediatr. 1985;31(4):229-34.

1550 Mills, R. P. Persistent middle ear effusions in children with recurrent acute otitis media. Clin Otolaryngol Allied Sci. 1987;12(2):97-101.

1551 Milnes, A. R.,Bowden, G. H. The microflora associated with developing lesions of nursing caries. Caries Res. 1985;19(4):289-97.
Independent variable

Study design Independent variable

Included for systematic reviews not completed

Study design

Study design

Dependent variable

Included for

systematic reviews not completed

Study design Independent variable

Study design, Health status

Study design, Health status

Dependent variable

Included for systematic reviews not completed

Study design, Dependent variable

Study design

Health status

Group size 
1552 Mimouni-Bloch, A.,Kachevanskaya, A.,Mimouni, F. B.,Shuper, A.,Raveh, E.,Linder, N. Breastfeeding may protect from developing attentiondeficit/hyperactivity disorder. Breastfeed Med. 2013;8(4):363-7.

Included for systematic reviews not completed

1553 Minchin, M. Artificial feeding and risk. Pract Midwife. 2000;3(3):18-20

Study design

1554 Minchin, M. Infant formula: a mass, uncontrolled trial in perinatal care. Birth. 1987;14(1):25-35.

Study design

1555 Mindru, D. E.,Moraru, E. Risk factors and their implications in the epidemiology of pediatric obesity. Rev Med Chir Soc Med Nat lasi. 2012;116(3):739-45

1556 Miranda, B. H.,Milroy, C. J. A quick snip - A study of the impact of outpatient tongue tie release on neonatal growth and breastfeeding. J Plast Reconstr Aesthet Surg. 2010;63(9):e683-5.

1557 Misra, S.,Sabui, T. K.,Basu, S.,Pal, N. A prospective study of rotavirus diarrhea in children under 1 year of age. Clin Pediatr (Phila). 2007;46(8):683-8.

1558 Mitchell, E. A.,Blair, P. S. SIDS prevention: 3000 lives saved but we can do better. N Z Med J. 2012;125(1359):50-7.

Study design

1559 Mitchell, E. A.,Esmail, A.,Jones, D. R.,Clements, M. Do differences in the prevalence of risk factors explain the higher mortality from sudden infant death syndrome in New Zealand compared with the UK?. N Z Med J. 1996;109(1030):352-5.

1560 Mitchell, E. A.,Scragg, R.,Stewart, A. W.,Becroft, D. M.,Taylor, B. J.,Ford, R. P.,Hassall, I. B.,Barry, D. M.,Allen, E. M.,Roberts, A. P. Results from the first year of the New Zealand cot death study. N Z Med J. 1991;104(906):71-6.

1561 Mitchell, E. A.,Stewart, A. W.,Scragg, R.,Ford, R. P.,Taylor, B. J.,Becroft, D. M.,Thompson, J. M.,Hassall, I. B.,Barry, D. M.,Allen, E. M.,et al.,. Ethnic differences in mortality from sudden infant death syndrome in New Zealand. BMJ. 1993;306(6869):13-6.

1562 Mitchell, E. A.,Thompson, J. M. Parental reported apnoea, admissions to hospital and sudden infant death syndrome. Acta Paediatr. 2001;90(4):417-22

1563 Mitchell, E. A.,Tuohy, P. G.,Brunt, J. M.,Thompson, J. M.,Clements, M. S.,Stewart, A. W.,Ford, R. P.,Taylor, B. J. Risk factors for sudden infant death syndrome following the prevention campaign in New Zealand: a prospective study. Pediatrics. 1997;100(5):835-40.

1564 Mittal, S. K. Bowel pattern and weight gain in breast fed infants. Indian Pediatr. 1988;25(2):216-7.

Study design

Independent variable

Country

Study design

Included for

systematic reviews not completed

Study design,

Independent variable

Study design,

Independent variable

Included for

systematic reviews not completed

Study design

Country

Study design $1983 ; 20(1): 21-6$

1566 Miyake, Y.,Tanaka, K.,Sasaki, S.,Kiyohara, C.,Ohya, Y.,Fukushima, W.,Yokoyama, T.,Hirota, Y. Breastfeeding and the risk of wheeze and asthma in Japanese infants: the Osaka Maternal and Child Health Study. Pediatr Allergy Immunol. 2008;19(6):490-6.

1567 Miyamoto, S.,Murotani, K.,Yanagawa, T.,Kato, A.,Matsunaga, S. Relationship of low lean body mass with body weight increase until one year of age and current lifestyles in Japanese young women. J Hum Ergol (Tokyo). 2010;39(1):45-51.
Study design, Independent variable 
1568 Mize, C. E.,Uauy, R.,Kramer, R.,Benser, M.,Allen, S.,Grundy, S. M.. Lipoprotein-cholesterol responses in healthy infants fed defined diets from ages 1 to 12 months: comparison of diets predominant in oleic acid versus linoleic acid, with parallel observations in infants fed a human milkbased diet. J Lipid Res. 1995;36(6):1178-87.

Included for systematic reviews not completed

Study design

1569 Mizuno, K.,Ueda, A., Takeuchi, T. Effects of different fluids on the relationship between swallowing and breathing during nutritive sucking in neonates. Biol Neonate. 2002;81(1):45-50.

1570 Modi, N.,Thomas, E. L.,Harrington, T. A.,Uthaya, S.,Dore, C. J.,Bell, J. D. Determinants of adiposity during preweaning postnatal growth in appropriately grown and growth-restricted term infants. Pediatr Res. 2006;60(3):345-8.

1571 Moimaz, S. A.,Garbin, A. J.,Lima, A. M.,Lolli, L. F.,Saliba, O.,Garbin, C. A. Longitudinal study of habits leading to malocclusion development in childhood. BMC Oral Health. 2014;14:96.

1572 Mok, J. Y.,Simpson, H. Outcome of acute lower respiratory tract infection in infants: preliminary report of seven-year follow-up study. Br Med $\mathrm{J}$ (Clin Res Ed). 1982;285(6338):333-7.

1573 Molgaard, C.,Larnkjaer, A.,Mark, A. B.,Michaelsen, K. F. Are early growth and nutrition related to bone health in adolescence? The Copenhagen Cohort Study of infant nutrition and growth. Am J Clin Nutr. 2011;94(6 Suppl):1865S-1869S.

1574 Molla, A. M.,Badawi, M. H.,Al-Yaish, S.,Sharma, P.,El-Salam, R. S.,Molla, A. M. Risk factors for nutritional rickets among children in Kuwait. Pediatrics International. 2000;42(3):280-284

1575 Mollborg, P.,Wennergren, G.,Almqvist, P.,Alm, B. Bed sharing is more common in sudden infant death syndrome than in explained sudden unexpected deaths in infancy. Acta Paediatr. 2015;104(8):777-83.

1576 Molokhia, E. A.,Perkins, A. Preventing cancer. Prim Care. 2008;35(4):609-23.

1577 Monobe, H.,Ishibashi, T.,Fujishiro, Y.,Shinogami, M.,Yano, J. Factors associated with poor outcome in children with acute otitis media. Acta Otolaryngol. 2003;123(5):564-8.

1578 Monson, T. P. Pediatric viral gastroenteritis. Am Fam Physician. 1986;34(1):95-9.

1579 Montagu, A. The skin, touch, and human development. Clin Dermatol. 1984;2(4):17-26.

1580 Monte, W. C.,Johnston, C. S.,Roll, L. E. Bovine serum albumin detected in infant formula is a possible trigger for insulin-dependent diabetes mellitus. J Am Diet Assoc. 1994;94(3):314-6.

1581 Montefort, S.,Muscat, H. A.,Caruana, S.,Lenicker, H. Allergic conditions in 5-8-year-old Maltese schoolchildren: prevalence, severity, and associated risk factors [ISAAC]. Pediatr Allergy Immunol. 2002;13(2):98-104.

1582 Monterrosa, E. C.,Frongillo, E. A.,Vasquez-Garibay, E. M.,Romero-Velarde, E.,Casey, L. M.,Willows, N. D. Predominant breast-feeding from birth to six months is associated with fewer gastrointestinal infections and increased risk for iron deficiency among infants. J Nutr. 2008;138(8):1499-504
Study design

Study design

Study design

Group size

Included for

systematic reviews not completed

Study design

Included for

systematic reviews not completed

Independent variable

Dependent variable

Study design, Nonhuman

Study design

Included for

systematic reviews not completed 
1584 Moon, R. Y.,Tanabe, K. O.,Yang, D. C.,Young, H. A.,Hauck, F. R. Pacifier use and SIDS: evidence for a consistently reduced risk. Maternal and child health journal. 2012;16(3):609-614.

Included for systematic reviews not completed

1585 Moore, Elizabeth R. Early Skin-To-Skin Contact for Mothers and Their Healthy Newborn Infants. JOGNN: Journal of Obstetric, Gynecologic \& Study design Neonatal Nursing. 2013;42:S86-S86 1p.

1586 Moore, S. R.,Lima, N. L.,Soares, A. M.,Oria, R. B.,Pinkerton, R. C.,Barrett, L. J.,Guerrant, R. L.,Lima, A. A. Prolonged episodes of acute diarrhea reduce growth and increase risk of persistent diarrhea in children. Gastroenterology. 2010;139(4):1156-64.

Included for systematic reviews not completed

1587 Moore, W. J.,Midwinter, R. E.,Morris, A. F.,Colley, J. R.,Soothill, J. F. Infant feeding and subsequent risk of atopic eczema. Arch Dis Child. 1985;60(8):722-6.

1588 Mora Urda, A. I.,Pereira da Silva, R.,Bisi Molina Mdel, C.,Bresciani Salaroli, L.,Montero Lopez Mdel, P. [RELATIONSHIP BETWEEN PATTERNS OF BREASTFEEDING AND BLOOD PRESSURE IN BRAZILIAN AND SPANISH SCHOOLCHILDREN]. Nutr Hosp. 2015;32(4):1568-75.

1589 Moraeus, L.,Lissner, L.,Yngve, A.,Poortvliet, E.,Al-Ansari, U.,Sjoberg, A. Multi-level influences on childhood obesity in Sweden: societal factors, parental determinants and child's lifestyle. Int J Obes (Lond). 2012;36(7):969-76. levels, breastfeeding, and child cognition. PLoS One. 2011;6(2):e17181.

1591 Moran, J. R. Effects of prolonged exposure to partially hydrolyzed milk protein. J Pediatr. 1992;121(5 Pt 2):S90-4.

Language Independent variable

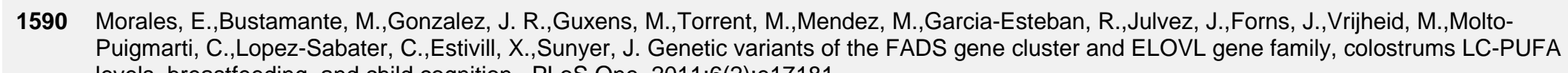

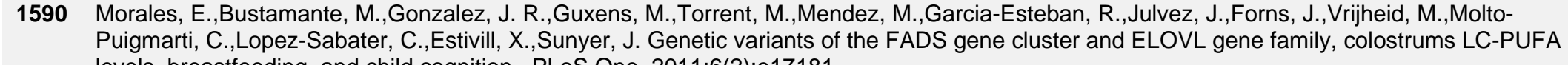

Group size systematic reviews not completed

1592 Moreno, M. Early infant feeding and obesity risk. JAMA Pediatr. 2014;168(11):1084. Study design

1593 Morgan, J. B.,Mumford, P. M. A follow-up study of nutrition and anthropometry in pre-school children. Proc Nutr Soc. 1980;39(1):5A. Peer review

1594 Morgan, J.,Taylor, A.,Fewtrell, M. Meat consumption is positively associated with psychomotor outcome in children up to 24 months of age. J Pediatr Gastroenterol Nutr. 2004;39(5):493-8.

Included for systematic reviews not completed

1595 Morin, K. H. Breastfeeding immediately after birth. MCN Am J Matern Child Nurs. 2009;34(1):63. Study design

1596 Morley, R. Iron supplemented follow-on formula and growth and development: a randomised trial [abstract]. Proc Nutr Soc Aust. $1998 ; 22: 288$.

Peer review

1597 Morley-Peet, P. Enteropathogenic Escherichia coli. Nurs Times. 1983;79(23):24-7. Study design 
1598 Moro, D. Birthweight and breast feeding of babies born during the war in one municipal area of Sarajevo. Eur J Clin Nutr. 1995;49 Suppl 2:S379.

1599 Morris, S. S.,Grantham-McGregor, S. M.,Lira, P. I.,Assuncao, A. M.,Ashworth, A. Effect of breastfeeding and morbidity on the development of low birthweight term babies in Brazil. Acta Paediatr. 1999;88(10):1101-6.

1600 Morrow, A. L. Infant feeding in the 21st century. J Pediatr Health Care. 2011;25(3):195-7.

Dependent variable

1601 Morrow, A. L.,Guerrero, M. L. From bioactive substances to research on breast-feeding promotion. Adv Exp Med Biol. 2001;501:447-55

Study design,

Independent variable

1602 Morrow, A. L.,Reves, R. R.,West, M. S.,Guerrero, M. L.,Ruiz-Palacios, G. M.,Pickering, L. K. Protection against infection with Giardia lamblia by breast-feeding in a cohort of Mexican infants. J Pediatr. 1992;121(3):363-70.

1603 Morrow-Tlucak, M.,Haude, R. H.,Ernhart, C. B. Breastfeeding and cognitive development in the first 2 years of life. Soc Sci Med. 1988;26(6):635-9.

1604 Mortensen, E. L.,Michaelsen, K. F.,Sanders, S. A.,Reinisch, J. M. The association between duration of breastfeeding and adult intelligence. JAMA. 2002;287(18):2365-71.

1605 Moschonis, G.,Grammatikaki, E.,Manios, Y. Perinatal predictors of overweight at infancy and preschool childhood: the GENESIS study. Int $J$ Obes (Lond). 2008;32(1):39-47.

1606 Moss, B. G.,Yeaton, W. H. Early childhood healthy and obese weight status: potentially protective benefits of breastfeeding and delaying solid foods. Matern Child Health J. 2014;18(5):1224-32.

1607 Mo-Suwan, L.,Junjana, C. Breast-feeding and infant growth in the first six months. J Med Assoc Thai. 1991;74(9):386-90. ndependent variable Included for systematic reviews not completed

Included for systematic reviews not completed

Study design

Included for systematic reviews not completed

Independent variable

1608 Motil, K. J.,Sheng, H. P.,Montandon, C. M.,Wong, W. W. Human milk protein does not limit growth of breast-fed infants. J Pediatr Gastroenterol Group size Nutr. 1997;24(1):10-7.

1609 Motta, M.,Tincani, A.,Faden, D.,Zinzini, E.,Lojacono, A.,Marchesi, A.,Frassi, M.,Biasini, C.,Zatti, S.,Chirico, G. Follow-up of infants exposed to hydroxychloroquine given to mothers during pregnancy and lactation. J Perinatol. 2005;25(2):86-9.

1610 Moxley, S.,Avni, G.,Brydon, S.,Kennedy, M. Breastfeeding and shorter hospital stays. Can Nurse. 1998;94(7):35-9.

Study design

1611 Mueller, W. H.,Pollitt, E. The Bacon Chow study: effects of nutrition supplementation on sibling-sibling anthropometric correlations. Hum Biol. 1982;54(3):455-68

1612 Mughal, M. Z.,Salama, H.,Greenaway, T.,Laing, I.,Mawer, E. B. Lesson of the week: florid rickets associated with prolonged breast feeding without vitamin D supplementation. Bmj. 1999;318(7175):39-40.
Study design,

Study design Independent variable 
1613 Mughini-Gras, L.,Pijnacker, R.,Heusinkveld, M.,Enserink, R.,Zuidema, R., Duizer, E., Kortbeek, T., van Pelt, W. Societal Burden and Correlates of Study design Acute Gastroenteritis in Families with Preschool Children. Sci Rep. 2016;6:22144.

1614 Muiño, A.,Menezes, A. M. B.,Reichert, F. F.,Duquia, R. P.,Chatkin, M. Wheezing phenotypes from birth to adolescence: A cohort study in Pelotas, Brazil, 1993-2004. Jornal Brasileiro de Pneumologia. 2008;34(6):347-355.

1615 Muirhead, P. A randomized controlled study of the effect of organised peer support on the duration of breast feeding and the consequences for infant morbidity. Personal communication. 1998.

\begin{tabular}{|c|c|c|}
\hline 1616 & Mukherjee, D.,Stephens, D. Otitis media with effusion in intellectually disabled children. Journal of Audiological Medicine. 1997;6(1):10-23. & $\begin{array}{l}\text { Study design, } \\
\text { Independent variable }\end{array}$ \\
\hline 1617 & $\begin{array}{l}\text { Mukhopadhya, J. Acute Respiratory Infection among children in an Air Force Community. Medical Journal Armed Forces India. 2001;57(4):309- } \\
311 .\end{array}$ & Country \\
\hline 1618 & $\begin{array}{l}\text { Mukhopadhyay, S.,Lieberman, E. S.,Puopolo, K. M.,Riley, L. E.,Johnson, L. C. Effect of early-onset sepsis evaluations on in-hospital } \\
\text { breastfeeding practices among asymptomatic term neonates. Hosp Pediatr. 2015;5(4):203-10. }\end{array}$ & Dependent variable \\
\hline 1619 & Mulhall AL. Breast feeding: a challenge for midwives. World Ir Nurs. 1984;13:8-9. & No full text \\
\hline 1620 & Muller, M. Nursing-bottle syndrome: risk factors. ASDC J Dent Child. 1996;63(1):42-50. & Study design \\
\hline
\end{tabular}

1621 Munir M,Mustadjab I,Rampengan TH,Wulur FH. Problem of infant feeding practices: implications for immediate action. Paediatr Indones. 1983;23:32-46.

1622 Munir, M. Infantile diarrhoea: breast and bottle feeding compared with special reference to their clinical role. Paediatr Indones. 1985;25(56):100-6.

1623 Muniz, L. C.,Menezes, A. M.,Assuncao, M. C.,Wehrmeister, F. C., Martinez-Mesa, J.,Goncalves, H.,Domingues, M. R.,Gigante, D. P.,Horta, B. L.,Barros, F. C. Breastfeeding and bone mass at the ages of 18 and 30: prospective analysis of live births from the Pelotas (Brazil) 1982 and 1993 cohorts. PLoS One. 2015;10(4):e0122759.

1624 Murdoch, W. Breast feeding. Cent Afr J Med. 1980;26(4):95-7.

Study design, Health status

Included for

systematic reviews not completed

Study design

1625 Murphy RM. The hidden epidemic. Can Nurse. 1981;77:42-3.

Study design

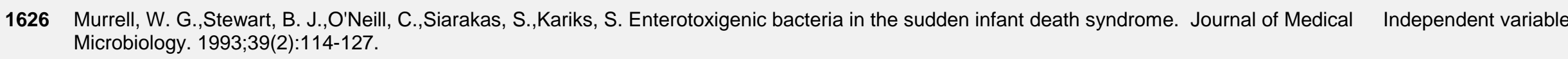

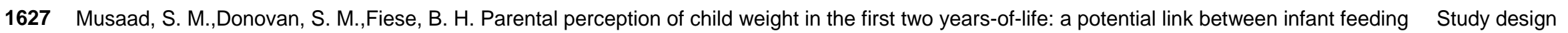
and preschoolers' diet. Appetite. 2015;91:90-100.

1628 Myres AW,Watson J,Harrison C. The national breast-feeding promotion program 1. Professional phase--a note on its development, distribution and impact. Can J Public Health. 1981;72:307-11. 
1629 Myres AW. The national breast-feeding promotion program. Part 2. Public information phase--a note on its development, distribution and impact. Can J Public Health. 1983;74:404-8.

Myres, A. W. Tradition and technology

1631 Nafstad, P.,Jaakkola, J. J.,Hagen, J. A.,Botten, G.,Kongerud, J. Breastfeeding, maternal smoking and lower respiratory tract infections. Eur Respir J. 1996;9(12):2623-9.

1632 Nafstad, P.,Jaakkola, J. J.,Hagen, J. A.,Pedersen, B. S.,Qvigstad, E.,Botten, G.,Kongerud, J. Weight gain during the first year of life in relation to maternal smoking and breast feeding in Norway. J Epidemiol Community Health. 1997;51(3):261-5.

1633 Nagahara, K.,Dobashi, K.,Itabashi, K. Feeding choice has a gender-associated effect on infant growth. Pediatr Int. 2013;55(4):481-7.

1634 Nagendra, R.,Viswanatha, S.,Arun Kumar, S.,Krishna Murthy, B.,Venkat Rao, S. Effect of feeding milk formula containing lactulose to infants on faecal bifidobacterial flora. Nutrition Research. 1995;15(1):15-24.

1635 Naggan, L.,Forman, M. R.,Sarov, B.,Lewando-Hundt, G.,Zangwill, L.,Chang, D.,Berendes, H. W. The Bedouin Infant Feeding Study: study design and factors influencing the duration of breast feeding. Paediatr Perinat Epidemiol. 1991;5(4):428-44.

1636 Najada, A. S.,Habashneh, M. S., Khader, M. The frequency of nutritional rickets among hospitalized infants and its relation to respiratory diseases. J Trop Pediatr. 2004;50(6):364-8.

1637 Nakamura, Y.,Oki, I.,Tanihara, S.,Ojima, T.,Ito, Y.,Yamazaki, O.,Iwama, M.,Tabata, Y.,Katsuyama, K.,Sasai, Y.,Nakagawa, M.,Matsushita A.,Hossaka, K.,Sato, J.,Hidaka, Y.,Uda, H.,Nakamata, K.,Yanagawa, H. Relationship between breast milk feeding and atopic dermatitis in children. J Epidemiol. 2000;10(2):74-8.

1638 Nakao, R. M. Effects of an education program on the health and illness profile of rural breast-fed babies. Philipp J Nurs. 1988;58(2):12-8.

1639 Nambiar, H. K. Acute diarrhoeal diseases: a malady in children. Nurs J India. 1984;75(8):179.

1640 Nambiar, Smita,Truby, Helen,Davies, Peter S. W. Exploring the influence of breastfeeding on abdominal adiposity in young children using the waist to height ratio. Nutrition \& Dietetics. 2013;70(2):146-152 7p.

1641 Narayan, N. R.,Mendez-Lagares, G.,Ardeshir, A.,Lu, D.,Van Rompay, K. K.,Hartigan-O'Connor, D. J. Persistent effects of early infant diet and associated microbiota on the juvenile immune system. Gut Microbes. 2015;6(4):284-9.

1642 Narayanan, I.,Gupta, J. Human milk and neonatal infections. Acta Paediatr Scand Suppl. 1989;351:126-30.

1643 Narayanan, I.,Prakash, K.,Murthy, N. S.,Gujral, V. V. Randomised controlled trial of effect of raw and holder pasteurised human milk and of formula supplements on incidence of neonatal infection. Lancet. 1984;2(8412):1111-3.
Dependent variable, Country

Study design

Dependent variable

Study design

Included for systematic reviews not completed

\section{Included for}

systematic reviews not completed

Included for

systematic reviews not

completed

Group size

Dependent variable

Study design, Health status

Study design

Country

Study design

Study design

Non-human

Country 
1645 Narese, F.,Puccio, G.,Mazzucco, W.,Falzone, A.,Venturella, V.,Narese, D.,Capra, E. Earlier appearance of the ossification center of the femoral Study design head in breast-fed versus formula-fed infants. Nutrition. 2011;27(11-12):1108-11.

1646 Nascimento Souza, Maria Helena,Aparecida Barbosa Nogueira, Josiê Neiber,Domingues Sodré, Vitória Regina. MONITORING THE NUTRITIONAL AND HEALTH STATUS OF CHILDREN WHO ATTEND A COMMUNITY NURSERY. Journal of Nursing UFPE / Revista de Enfermagem UFPE. 2015;9(5):7862-7868 7p.

1647 Nassar, M. F.,Younis, N. T.,El-Arab, S. E.,Fawzi, F. A. Neuro-developmental outcome and brain-derived neurotrophic factor level in relation to feeding practice in early infancy. Matern Child Nutr. 2011;7(2):188-97.

1648 Nauta, A. Specific nutritional concepts \& clinical evidence in the management of allergy. Asian Pacific Journal of Allergy and Immunology. 2012;30(4 SUPPL):S21-S24.

1649 Navarro, J. I.,Sigulem, D. M.,Ferraro, A. A.,Polanco, J. J.,Barros, A. J. The double task of preventing malnutrition and overweight: a quasiexperimental community-based trial. BMC Public Health. 2013;13:212.

1650 Nelson, C. M.,Innis, S. M. Plasma lipoprotein fatty acids are altered by the positional distribution of fatty acids in infant formula triacylglycerols and human milk. Am J Clin Nutr. 1999;70(1):62-9.

1651 Nelson, C. M.,Innis, S. M.,Walsen, P.,Whitfield, M. Prospective measures of visual and cognitive development in term gestation breast-fed and formula-fed infants to 18 months of age. Pediatric research. 2002;2:315a.

1652 Nelson, E. A.,Yu, L. M.,Wong, D.,Wong, H. Y.,Yim, L. Rolling over in infants: age, ethnicity, and cultural differences. Dev Med Child Neurol. 2004;46(10):706-9

1653 Nelson, J. D. Prevention of gastrointestinal infections. Pediatr Infect Dis. 1985;4(4):431-4.

Study design, Independent variable

Study design

Study design Independent variable

Group size

Peer review

Group size

Study design, Independent variable

1654 Nelson, M. C.,Gordon-Larsen, P.,Adair, L. S. Are adolescents who were breast-fed less likely to be overweight? Analyses of sibling pairs to reduce confounding. Epidemiology. 2005;16(2):247-53.

Included for systematic reviews not completed

1655 Nelson, S. E.,Rogers, R. R.,Ziegler, E. E.,Fomon, S. J. Gain in weight and length during early infancy. Early Hum Dev. 1989;19(4):223-39.

Included for systematic reviews not completed

1656 Nelson, S.,Albert, J. M.,Soderling, E.,Malik, A.,Curtan, S.,Geng, C.,Milgrom, P. Increased number of teeth predict acquisition of mutans streptococci in infants. Eur J Oral Sci. 2014;122(5):346-52.

Included for

systematic reviews not completed

1657 Nentwich, I.,Michkova, E.,Nevoral, J.,Urbanek, R.,Szepfalusi, Z. Cow's milk-specific cellular and humoral immune responses and atopy skin Group size symptoms in infants from atopic families fed a partially (pHF) or extensively (eHF) hydrolyzed infant formula. Allergy. 2001;56(12):1144-56. 
1658 Nery Cde, G.,Buranello, F. S.,Pereira, C.,Di Francesco, R. C. Otitis media with effusion and dental occlusion: is there any relationship?. Eur J Paediatr Dent. 2010;11(3):132-6.

1659 Neutzling, M. B.,Hallal, P. R.,Araujo, C. L.,Horta, B. L.,Vieira Mde, F.,Menezes, A. M.,Victora, C. G. Infant feeding and obesity at 11 years: prospective birth cohort study. Int J Pediatr Obes. 2009;4(3):143-9.

1660 Neves, A. B.,Lobo, L. A.,Pinto, K. C.,Pires, E. S.,Requejo, M.,Maia, L. C.,Antonio, A. G. Comparison between Clinical Aspects and Salivary Microbial Profile of Children with and without Early Childhood Caries: A Preliminary Study. J Clin Pediatr Dent. 2015;39(3):209-14.

1661 Newburg, D. S.,Ruiz-Palacios, G. M.,Altaye, M.,Chaturvedi, P.,Guerrero, M. L.,Meinzen-Derr, J. K., Morrow, A. L. Human milk alphal,2-linked fucosylated oligosaccharides decrease risk of diarrhea due to stable toxin of E. coli in breastfed infants. Adv Exp Med Biol. 2004;554:457-61.

1662 Newman, J. How breast milk protects newborns. Sci Am. 1995;273(6):76-9

Independent variable, Health status

Included for systematic reviews not completed

Study design

Independent variable

Study design

Study design infant adiposity. Ann Acad Med Singapore. 2004;33(5 Suppl):S75.

1664 Ng, S. C., Tang, W.,Leong, R. W.,Chen, M.,Ko, Y.,Studd, C.,Niewiadomski, O.,Bell, S., Kamm, M. A.,de Silva, H. J.,Kasturiratne, A.,Senanayake, Y. U.,Ooi, C. J.,Ling, K. L.,Ong, D.,Goh, K. L.,Hilmi, I.,Ouyang, Q.,Wang, Y. F.,Hu, P.,Zhu, Z.,Zeng, Z.,Wu, K.,Wang, X., Xia, B.,Li, J.,Pisespongsa, P.,Manatsathit, S.,Aniwan, S.,Simadibrata, M.,Abdullah, M.,Tsang, S. W.,Wong, T. C.,Hui, A. J.,Chow, C. M.,Yu, H. H.,Li, M. F.,Ng, K. K.,Ching, J.,Wu, J. C.,Chan, F. K.,Sung, J. J. Environmental risk factors in inflammatory bowel disease: a population-based casecontrol study in Asia-Pacific. Gut. 2015;64(7):1063-71.

1665 Ngale, K. M.,Santos, I. S.,Gonzalez-Chica, D. A.,de Barros, A. J.,Matijasevich, A. Bed-sharing and risk of hospitalisation due to pneumonia and diarrhoea in infancy: the 2004 Pelotas Birth Cohort. J Epidemiol Community Health. 2013;67(3):245-9.

1666 Ngamphaiboon, J. Food allergy and wheezing. Southeast Asian J Trop Med Public Health. 2014;45 Suppl 1:95-9.

Included for

systematic reviews not completed

Study design

1667 Ngamphaiboon, J.,Tansupapol, C.,Chatchatee, P. The efficacy of partially hydrolyzed formulas for allergy prevention in children under five years Asian Biomedicine. 2009;3(3):245-254

1668 Nguyen, N. D.,Allen, J. R.,Peat, J. K.,Beal, P.,Webster, B. H.,Gaskin, K. J. Iron status of young Vietnamese children in Australia. J Paediatr Child Health. 2004;40(8):424-9

1669 Nguyen, N. D.,Allen, J. R.,Peat, J. K.,Schofield, W. N.,Nossar, V.,Eisenbruch, M.,Gaskin, K. J. Growth and feeding practices of Vietnamese infants in Australia. Eur J Clin Nutr. 2004;58(2):356-62.

1670 Nicolai, A.,Nenna, R.,Stefanelli, P.,Carannante, A.,Schiavariello, C.,Pierangeli, A.,Scagnolari, C.,Moretti, C.,Papoff, P.,Bonci, E.,Ferrara, M.,Papasso, S.,Midulla, F. Bordetella pertussis in infants hospitalized for acute respiratory symptoms remains a concern. BMC Infect Dis. 2013;13:526

1671 Nicoll, A.,Williams, A. Breast feeding. Arch Dis Child. 2002;87(2):91-2.

Study design
Study design Independent variable

Independent variable

Group size 
1672 Niegel, S.,Ystrom, E.,Hagtvet, K. A.,Vollrath, M. E. Difficult temperament, breastfeeding, and their mutual prospective effects: the Norwegian Mother and Child Cohort Study. J Dev Behav Pediatr. 2008;29(6):458-62.

1673 Nielsen, G. A.,Thomsen, B. L.,Michaelsen, K. F. Influence of breastfeeding and complementary food on growth between 5 and 10 months. Acta Paediatr. 1998;87(9):911-7.

1674 Nielsen, S. B.,Reilly, J. J.,Fewtrell, M. S.,Eaton, S.,Grinham, J.,Wells, J. C. Adequacy of milk intake during exclusive breastfeeding: a longitudinal study. Pediatrics. 2011;128(4):e907-14.

1675 Niemela, A.,Jarvenpaa, A. L. Is breastfeeding beneficial and maternal smoking harmful to the cognitive development of children?. Acta Paediatr. 1996;85(10):1202-6.

1676 Niemela, M.,Uhari, M.,Mottonen, M. A pacifier increases the risk of recurrent acute otitis media in children in day care centers. Pediatrics. 1995;96(5 Pt 1):884-8.

1677 Nikpour, S.,Rahimian, Sh,Shokrabi, S.,Haghani, H. Related Factors of Acute Leukemia in Children and the Role of Breast Feeding. Iranian Journal of Endocrinology \& Metabolism. 2012;14(1):63-97 35p.

1678 Nishimura, M.,Oda, T.,Kariya, N.,Matsumura, S.,Shimono, T. Using a caries activity test to predict caries risk in early childhood. J Am Dent Assoc. 2008;139(1):63-71.

1679 Nishimura, T.,Suzue, J.,Kaji, H. Breastfeeding reduces the severity of respiratory syncytial virus infection among young infants: a multi-cente prospective study. Pediatr Int. 2009;51(6):812-6.

1680 Nnanyelugo, D. O. Nutritional practices and food intake measurements and their relationship to socio-economic grouping, location and their apparent nutritional adequacy in children. Appetite. 1982;3(3):229-41.

1681 Noda, M.,Sato, N.,Tanaka, T. Growth failure starts from early infancy in children with short stature at age 6. Clinical Pediatric Endocrinology. 2015;24(1):1-10

1682 Nolan, L.,Goel, V. Sociodemographic factors related to breastfeeding in Ontario: results from the Ontario Health Survey. Can J Public Health. 1995;86(5):309-12.

1683 Nommsen-Rivers, L. A. Does breastfeeding protect against infant mortality in the United States?. J Hum Lact. 2004;20(3):357-8.

1684 Nossar, V.,Hudson, D. Improving health outcomes for children by home visiting. Medicine Today. 2001;2(8):135-136.

1685 Nott, S. Some faults on feeding. Midwife Health Visit Community Nurse. 1985;21(6):201-2.

1686 Novotny, R.,Daida, Y. G.,Grove, J. S.,Acharya, S.,Vogt, T. M. Formula feeding in infancy is associated with adolescent body fat and earlier menarche. Cell Mol Biol (Noisy-le-grand). 2003;49(8):1289-93.
Independent variable

Included for systematic reviews not completed

Dependent variable

Included for

systematic reviews not completed

Included for

systematic reviews not completed

Language

Included for systematic reviews not completed

Included for systematic reviews not completed

Country

Study design

Study design

Study design

Study design

Study design

Study design 
1688 Nuesslein, T. G.,Beckers, D.,Rieger, C. H. Cotinine in meconium indicates risk for early respiratory tract infections. Hum Exp Toxicol. 1999;18(4):283-90.

1689 Nunes, A. M.,Alves, C. M.,Borba de Araujo, F.,Ortiz, T. M.,Ribeiro, M. R.,Silva, A. A.,Ribeiro, C. C. Association between prolonged breastfeeding and early childhood caries: a hierarchical approach. Community Dent Oral Epidemiol. 2012;40(6):542-9.

1690 Nutrition for mother and child. Nurs J India. 1990;81(6):181-8.

Study design

1691 Nutritional adequacy of breast feeding. Nutr Rev. 1980;38:145-7.

Study design

Study design

1692 Nwaru, B. I.,Erkkola, M.,Ahonen, S.,Kaila, M.,Haapala, A. M.,Kronberg-Kippila, C.,Salmelin, R.,Veijola, R.,Ilonen, J.,Simell, O.,Knip, M.,Virtanen, S. M.. Age at the introduction of solid foods during the first year and allergic sensitization at age 5 years. Pediatrics. 2010;125(1):50-9.

1693 Nwaru, B. I.,Takkinen, H. M.,Niemela, O.,Kaila, M.,Erkkola, M.,Ahonen, S.,Tuomi, H.,Haapala, A. M.,Kenward, M. G.,Pekkanen, J.,Lahesmaa, R.,Kere, J.,Simell, O.,Veijola, R.,Ilonen, J.,Hyoty, H.,Knip, M.,Virtanen, S. M.. Introduction of complementary foods in infancy and atopic sensitization at the age of 5 years: timing and food diversity in a Finnish birth cohort. Allergy. 2013;68(4):507-16.

1694 Nylander, G.,Lindemann, R.,Helsing, E.,Bendvold, E. Unsupplemented breastfeeding in the maternity ward. Positive long-term effects. Acta Obstet Gynecol Scand. 1991;70(3):205-9.

1695 Obel, C.,Henriksen, T. B.,Hedegaard, M.,Secher, N. J.,Ostergaard, J. Smoking during pregnancy and babbling abilities of the 8-month-old infant. Paediatr Perinat Epidemiol. 1998;12(1):37-48.

1696 Ochoa, M. C.,Moreno-Aliaga, M. J.,Martinez-Gonzalez, M. A.,Martinez, J. A.,Marti, A. Predictor factors for childhood obesity in a Spanish casecontrol study. Nutrition. 2007;23(5):379-84

Dependent variable

Dependent variable

Independent variable

Independent variable

Included for

systematic reviews not completed

1697 O'Connell, J. M.,Dibley, M. J.,Sierra, J.,Wallace, B.,Marks, J. S.,Yip, R. Growth of vegetarian children: The Farm Study. Pediatrics

Independent variable 1989;84(3):475-81

1698 O'Connor, P. A. Clouds, skin color, and rickets. Pediatrics. 1980;66(2):332.

Study design

1699 Oddy, W. H. Breastfeeding and asthma in children. A prospective cohort study. Adv Exp Med Biol. 2000;478:393-4.

Study design

1700 Oddy, W. H. Breastfeeding and asthma in children: findings from a West Australian study. Breastfeed Rev. 2000;8(1):5-11.

Redundant data

1701 Oddy, W. H.,de Klerk, N. H.,Sly, P. D.,Holt, P. G.. The effects of respiratory infections, atopy, and breastfeeding on childhood asthma. Eur Respir J. 2002;19(5):899-905.

\section{Included for}

systematic reviews not completed

1702 Oddy, W. H.,Halonen, M.,Martinez, F. D.,Lohman, I. C.,Stern, D. A.,Kurzius-Spencer, M.,Guerra, S.,Wright, A. L. TGF-beta in human milk is

Dependent variable associated with wheeze in infancy. J Allergy Clin Immunol. 2003;112(4):723-8. 
1704 Oddy, W. H.,Kendall, G. E.,Blair, E.,De Klerk, N. H.,Stanley, F. J.,Landau, L. I.,Silburn, S.,Zubrick, S. Breast feeding and cognitive development in childhood: a prospective birth cohort study. Paediatr Perinat Epidemiol. 2003;17(1):81-90.

Included for systematic reviews not completed

1705 Oddy, W. H.,Kendall, G. E.,Li, J.,Jacoby, P.,Robinson, M.,de Klerk, N. H.,Silburn, S. R.,Zubrick, S. R.,Landau, L. I.,Stanley, F. J. The long-term effects of breastfeeding on child and adolescent mental health: a pregnancy cohort study followed for 14 years. J Pediatr. 2010;156(4):568-74.

Included for systematic reviews not completed

1706 Oddy, W. H.,Kickett-Tucker, C.,De Maio, J.,Lawrence, D.,Cox, A.,Silburn, S. R.,Stanley, F. J.,Zubrick, S. R. The association of infant feeding with parent-reported infections and hospitalisations in the West Australian Aboriginal Child Health Survey. Aust N Z J Public Health.

Included for systematic reviews not 2008;32(3):207-15

completed

1707 Oddy, W. H.,Li, J.,Whitehouse, A. J. O.,Zubrick, S. R.,Malacova, E. Breastfeeding duration and academic achievement at 10 years. Pediatrics. 2011;127(1):e137-e145.

Included for

systematic reviews not

completed

1708 Oddy, W. H.,Mori, T. A.,Huang, R. C.,Marsh, J. A.,Pennell, C. E.,Chivers, P. T.,Hands, B. P.,Jacoby, P.,Rzehak, P.,Koletzko, B. V.,Beilin, L. J. Early infant feeding and adiposity risk: From infancy to adulthood. Annals of Nutrition and Metabolism. 2014;64(3-4):262-270.

Included for

systematic reviews not completed

1709 Oddy, W. H.,Peat, J. K., de Klerk, N. H. Maternal asthma, infant feeding, and the risk of asthma in childhood. J Allergy Clin Immunol. Independent variable 2002;110(1):65-7.

1710 Oddy, W. H.,Robinson, M.,Kendall, G. E.,Li, J.,Zubrick, S. R.,Stanley, F. J. Breastfeeding and early child development: a prospective cohort study. Acta Paediatr. 2011;100(7):992-9.

Included for

systematic reviews not completed

Included for

systematic reviews not completed

Included for

systematic reviews not completed breastfeeding and body mass index to asthma and atopy in children: a prospective cohort study to age 6 years. Am J Public Health. 2004;94(9):1531-7.

1713 Oddy, W. H.,Sly, P. D.,de Klerk, N. H.,Landau, L. I.,Kendall, G. E.,Holt, P. G.,Stanley, F. J. Breast feeding and respiratory morbidity in infancy: a birth cohort study. Arch Dis Child. 2003;88(3):224-8.

Included for systematic reviews not completed

Study design Independent variable

1714 Oddy, W. H.,Smith, G. J.,Jacoby, P. A possible strategy for developing a model to account for attrition bias in a longitudinal cohort to investigate associations between exclusive breastfeeding and overweight and obesity at 20 years. Ann Nutr Metab. 2014;65(2-3):234-5. 
1715 Odelram, H.,Vanto, T.,Jacobsen, L.,Kjellman, N. I. Whey hydrolysate compared with cow's milk-based formula for weaning at about 6 months of age in high allergy-risk infants: effects on atopic disease and sensitization. Allergy. 1996;51(3):192-5.

1716 O'Donovan, S. M.,O'B Hourihane J,Murray, D. M.,Kenny, L. C., Khashan, A. S.,Chaoimh, C. N.,Irvine, A. D., Kiely, M. Neonatal adiposity increases the risk of atopic dermatitis during the first year of life. J Allergy Clin Immunol. 2015.

Independent variable Independent variable

1717 Ogston, S. A.,Florey, C. D.,Walker, C. H. Association of infant alimentary and respiratory illness with parental smoking and other environmental factors. J Epidemiol Community Health. 1987;41(1):21-5.

1718 Ohlund, I.,Hornell, A.,Lind, T.,Hernell, O.. Dietary fat in infancy should be more focused on quality than on quantity. Eur J Clin Nutr. 2008;62(9):1058-64.

1719 Oken, E.,Osterdal, M. L., Gillman, M. W.,Knudsen, V. K.,Halldorsson, T. I.,Strom, M.,Bellinger, D. C.,Hadders-Algra, M.,Michaelsen, K. F.,Olsen, S. F. Associations of maternal fish intake during pregnancy and breastfeeding duration with attainment of developmental milestones in early childhood: a study from the Danish National Birth Cohort. Am J Clin Nutr. 2008;88(3):789-96.

1720 Olaya, G. A.,Lawson, M.,Fewtrell, M. S. Efficacy and safety of new complementary feeding guidelines with an emphasis on red meat consumption: a randomized trial in Bogota, Colombia. Am J Clin Nutr. 2013;98(4):983-93.

1721 Oliveira, A. F.,Chaves, A. M.,Rosenblatt, A. The influence of enamel defects on the development of early childhood caries in a population with low socioeconomic status: a longitudinal study. Caries Res. 2006;40(4):296-302.

1722 Oliveira, E. A.,Bertoldi, A. D.,Domingues, M. R.,Santos, I. S.,Barros, A. J. Factors associated to medicine use among children from the 2004 Pelotas Birth Cohort (Brazil). Rev Saude Publica. 2012;46(3):487-96.

1723 Ollila, P.,Larmas, M. A seven-year survival analysis of caries onset in primary second molars and permanent first molars in different caries risk groups determined at age two years. Acta Odontol Scand. 2007;65(1):29-35.

Included for

systematic reviews not completed

Dependent variable

Included for

systematic reviews not completed

Independent variable

Independent variable

Dependent variable

Included for systematic reviews not completed

1724 Ölmez, S.,Uzamiş, M. Risk factors of early childhood caries in Turkish children. Turkish Journal of Pediatrics. 2002;44(3):230-236.

Study design

1725 Olmez, S.,Uzamis, M.,Erdem, G. Association between early childhood caries and clinical, microbiological, oral hygiene and dietary variables in rural Turkish children. Turk J Pediatr. 2003;45(3):231-6.

1726 Olson, C. M.,Baker, I. R.,Demment, M. M.,Graham, M. L.,May, J. J.,Strawderman, M. S.,Wells, N. M. The healthy start partnership: an approach to obesity prevention in young families. Fam Community Health. 2014;37(1):74-85.

1727 Ong, K. K.,Ahmed, M. L., Sherriff, A.,Woods, K. A.,Watts, A., Golding, J.,Dunger, D. B. Cord blood leptin is associated with size at birth and predicts infancy weight gain in humans. ALSPAC Study Team. Avon Longitudinal Study of Pregnancy and Childhood. J Clin Endocrinol Metab. 1999;84(3):1145-8.

1728 Ong, K. K.,Emmett, P. M.,Noble, S.,Ness, A.,Dunger, D. B. Dietary energy intake at the age of 4 months predicts postnatal weight gain and childhood body mass index. Pediatrics. 2006;117(3):e503-8.
Study design

Independent variable

Independent variable

Independent variable 
1729 Ong, K. K.,Preece, M. A.,Emmett, P. M.,Ahmed, M. L.,Dunger, D. B. Size at birth and early childhood growth in relation to maternal smoking parity and infant breast-feeding: longitudinal birth cohort study and analysis. Pediatr Res. 2002;52(6):863-7.
Included for systematic reviews not completed

Study design

Study design

Study design

Included for

systematic reviews not completed

Dependent variable

Dependent variable Full breastfeeding and paediatric cancer. J Paediatr Child Health. 2008:44(1-2):10-3.

1735 O'Ryan, M. L.,Lucero, Y.,Rabello, M.,Mamani, N.,Salinas, A. M.,Pena, A.,Torres-Torreti, J. P.,Mejias, A.,Ramilo, O.,Suarez, N.,Reynolds, H. E.,Orellana, A.,Lagomarcino, A. J. Persistent and transient Helicobacter pylori infections in early childhood. Clin Infect Dis. 2015;61(2):211-8.

1736 Ostrom, K. M.,Cordle, C. T.,Schaller, J. P.,Winship, T. R., Thomas, D. J.,Jacobs, J. R.,Blatter, M. M.,Cho, S.,Gooch, W. M., 3rd,Granoff, D. M.,Faden, H.,Pickering, L. K. Immune status of infants fed soy-based formulas with or without added nucleotides for 1 year: part 1: vaccine responses, and morbidity. J Pediatr Gastroenterol Nutr. 2002;34(2):137-44.

Included for systematic reviews not completed

1737 O'Sullivan, D. M.,Tinanoff, N. Social and biological factors contributing to caries of the maxillary anterior teeth. Pediatr Dent. 1993;15(1):41-4.

Study design

1738 Oti-Boateng, P.,Seshadri, R.,Petrick, S.,Gibson, R. A.,Simmer, K. Iron status and dietary iron intake of 6-24-month-old children in Adelaide. J Paediatr Child Health. 1998;34(3):250-3.

1739 O'Tierney, P. F.,Barker, D. J.,Osmond, C.,Kajantie, E.,Eriksson, J. G. Duration of breast-feeding and adiposity in adult life. J Nutr. 2009;139(2):422S-5S.

Study design

Included for systematic reviews not completed

Dependent variable

1740 Ou, X.,Andres, A.,Cleves, M. A.,Pivik, R. T.,Snow, J. H.,Ding, Z.,Badger, T. M. Sex-specific association between infant diet and white matter integrity in 8-y-old children. Pediatr Res. 2014;76(6):535-43.

1741 Oulis, C. J.,Berdouses, E. D.,Vadiakas, G.,Lygidakis, N. A. Feeding practices of Greek children with and without nursing caries. Pediatr Dent. 1999;21(7):409-16

1742 Ounsted, M. K.,Moar, V. A.,Scott, A. Small-for-dates babies at the age of four years: health, handicap and developmental status. Early Hum Dev. 1983;8(3-4):243-58.
Study design

Independent variable 
1743 Ounsted, M.,Moar, V. A.,Cockburn, J.,Redman, C. W. Factors associated with the intellectual ability of children born to women with high risk pregnancies. Br Med J (Clin Res Ed). 1984;288(6423):1038-41.

1744 Ovsenik, M. Incorrect orofacial functions until 5 years of age and their association with posterior crossbite. Am J Orthod Dentofacial Orthop. 2009;136(3):375-81.

1745 Owen, G. M.,Garry, P. J.,Hooper, E. M.,Gilbert, B. A.,Pathak, D. Iron nutriture of infants exclusively breast-fed the first five months. J Pediatr. 1981;99(2):237-40

1746 Owen, M. J.,Baldwin, C. D.,Swank, P. R.,Pannu, A. K.,Johnson, D. L.,Howie, V. M. Relation of infant feeding practices, cigarette smoke exposure, and group child care to the onset and duration of otitis media with effusion in the first two years of life. J Pediatr. 1993;123(5):702-11.

1747 Ozden, T. A.,Gokcay, G.,Cantez, M. S.,Durmaz, O.,Issever, H.,Omer, B.,Saner, G. Copper, zinc and iron levels in infants and their mothers during the first year of life: a prospective study. BMC Pediatr. 2015;15(1):157.

1748 Ozmert, E. N.,Kale-Cekinmez, E.,Yurdakok, K.,Sekerel, B. E. Determinants of allergic signs and symptoms in 24- 48-month-old Turkish children. Turk J Pediatr. 2009;51(2):103-9.

1749 Ozmert, E. N.,Yurdakok, K.,Soysal, S.,Kulak-Kayikci, M. E.,Belgin, E.,Ozmert, E.,Laleli, Y.,Saracbasi, O. Relationship between physical, environmental and sociodemographic factors and school performance in primary schoolchildren. J Trop Pediatr. 2005;51(1):25-32.

1750 Pacheco, G.,Hedges, M.,Schilling, C.,Morton, S. Pre- and postnatal drivers of childhood intelligence: evidence from Singapore. J Biosoc Sci. 2013;45(1):41-56.

1751 Paine, B. J.,Makrides, M.,Gibson, R. A. Duration of breast-feeding and Bayley's Mental Developmental Index at 1 year of age. J Paediatr Child Health. 1999;35(1):82-5.

1752 Paine, R.,Coble, R. J. Breast-feeding and infant health in a rural US community. Am J Dis Child. 1982;136(1):36-8.

1753 Palloni, A.,Aguirre, G. P.,Lastiri, S. The effects of breast-feeding and the pace of childbearing on early childhood mortality in Mexico. Bull Pan Am Health Organ. 1994;28(2):93-111.

1754 Palloni, A.,Tienda, M. The effects of breastfeeding and pace of childbearing on mortality at early ages. Demography. 1986;23(1):31-52.

1755 Palma, G. D.,Capilla, A.,Nova, E.,Castillejo, G.,Varea, V.,Pozo, T.,Garrote, J. A.,Polanco, I.,Lopez, A.,Ribes-Koninckx, C.,Marcos, A.,GarciaNovo, M. D.,Calvo, C.,Ortigosa, L.,Pena-Quintana, L.,Palau, F.,Sanz, Y. Influence of milk-feeding type and genetic risk of developing coeliac disease on intestinal microbiota of infants: the PROFICEL study. PLoS One. 2012;7(2):e30791.

1756 Palmer, M. M.,VandenBerg, K. A. A closer look at neonatal sucking. Neonatal Netw. 1998;17(2):77-9.

1757 Palti, H.,Mansbach, I.,Pridan, H.,Adler, B.,Palti, Z. Episodes of illness in breast-fed and bottle-fed infants in Jerusalem. Isr J Med Sci. 1984;20(5):395-9.

1758 Palvo, F.,Toledo, E. C.,Menin, A. M.,Jorge, P. P.,Godoy, M. F.,Sole, D. Risk factors of childhood asthma in Sao Jose do Rio Preto, Sao Paulo, Brazil. J Trop Pediatr. 2008;54(4):253-7.
Study design

Study design

Independent variable

Independent variable

Included for

systematic reviews not completed

Study design,

ndependent variable

Study design

Study design

Study design

Study design

Independent variable

Study design

Independent variable

Study design

Dependent variable

Independent variable

Study design 
1759 Panagiotakos, D. B.,Papadimitriou, A.,Anthracopoulos, M. B.,Konstantinidou, M.,Antonogeorgos, G.,Fretzayas, A.,Priftis, K. N. Birthweight, breast-feeding, parental weight and prevalence of obesity in schoolchildren aged 10-12 years, in Greece; the Physical Activity, Nutrition and Allergies in Children Examined in Athens (PANACEA) study. Pediatr Int. 2008;50(4):563-8.

1760 Panico, L.,Stuart, B.,Bartley, M.,Kelly, Y. Asthma trajectories in early childhood: identifying modifiable factors. PLoS One. $2014 ; 9(11): e 111922$.

Dependent variable

1761 Papandreou, D.,Malindretos, P.,Rousso, I. Risk factors for childhood obesity in a Greek paediatric population. Public Health Nutr. 2010;13(10):1535-9.

1762 Papenburg, J.,Hamelin, M. E.,Ouhoummane, N.,Carbonneau, J.,Ouakki, M.,Raymond, F.,Robitaille, L.,Corbeil, J.,Caouette, G.,Frenette, L.,De Serres, G.,Boivin, G. Comparison of risk factors for human metapneumovirus and respiratory syncytial virus disease severity in young children. J Infect Dis. 2012;206(2):178-89.

1763 Papp, L. M. Longitudinal associations between breastfeeding and observed mother-child interaction qualities in early childhood. Child Care Health Dev. 2014;40(5):740-6.

1764 Paradise, J. L.,Rockette, H. E.,Colborn, D. K.,Bernard, B. S.,Smith, C. G.,Kurs-Lasky, M.,Janosky, J. E. Otitis media in 2253 Pittsburgh-area infants: prevalence and risk factors during the first two years of life. Pediatrics. 1997;99(3):318-33.

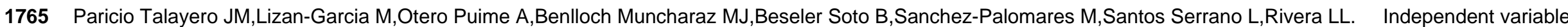
Full breastfeeding and hospitalization as a result of infections in the first year of life. Pediatrics. 2006;118:e92-9.

1766 Park, J.,Kim, H. S.,Chu, S. H.,Jekal, Y. S.,Lee, J. Y. The effect of predominant breast-feeding on the risk of obesity in Korean preschool children. Study design Nurs Health Sci. 2015.

1767 Park, M. J.,Namgung, R.,Kim, D. H.,Tsang, R. C. Bone mineral content is not reduced despite low vitamin D status in breast milk-fed infants versus cow's milk based formula-fed infants. J Pediatr. 1998;132(4):641-5.

1768 Park, S.,Kim, B. N.,Kim, J. W.,Shin, M. S.,Yoo, H. J.,Cho, S. C. Protective effect of breastfeeding with regard to children's behavioral and cognitive problems. Nutr J. 2014;13(1):111.

1769 Parsons, T. J.,Power, C.,Manor, O. Infant feeding and obesity through the lifecourse. Arch Dis Child. 2003;88(9):793-4.

\section{Group size}

Study design

Included for systematic reviews not completed

1770 Paszkowski, J.,Lopatynski, J. Allergy to house dust mites in primary health care subjects with chronic or recurrent inflammatory states of Health status respiratory system. Ann Univ Mariae Curie Sklodowska Med. 2002;57(1):522-30.

1771 Patel, J. A.,Alvarez-Fernandez, P.,Jennings, K.,Loeffelholz, M.,McCormick, D.,Chonmaitree, T. Factors Affecting Staphylococcus aureus Colonization of the Nasopharynx in the First 6 Months of Life. Pediatr Infect Dis J. 2015;34(8):826-30.

1772 Patel, J. A.,Nair, S.,Revai, K.,Grady, J.,Saeed, K.,Matalon, R.,Block, S., Chonmaitree, T. Association of proinflammatory cytokine gene polymorphisms with susceptibility to otitis media. Pediatrics. 2006;118(6):2273-9. 
1773 Paterson, J. E.,Gao, W.,Sundborn, G.,Cartwright, S. Maternal self-report of oral health in six-year-old Pacific children from South Auckland, New Zealand. Community Dent Oral Epidemiol. 2011;39(1):19-28.
Included for systematic reviews not completed

Included for systematic reviews not completed

\section{Country}

Patra, S.,Singh, V.,Kumar, P.,Chandra, J.,Dutta, A., Tripathi,
wheezing. J Coll Physicians Surg Pak. 2011;21(11):715-7.

1776 Patsourou, A.,Konstantinides, T.,Mantadakis, E.,Tsalkidis, A.,Zarras, C.,Balaska, A.,,Simopoulos, K., Chatzimichael, A. Growth of exclusively breastfed and self-weaned children of Greece aged 0-36 months. Breastfeed Med. 2012;7(6):521-5

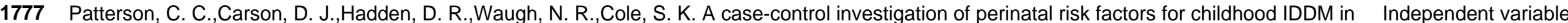
Northern Ireland and Scotland. Diabetes Care. 1994;17(5):376-81.

1778 Patwari, A. K. Breastfeeding and atopy. Indian Pediatr. 1996;33(3):265-6.

Study design, Country

1779 Paul A,Whitehead R. Infant feeding: the weighting game. Community Outlook. 1986:11-7.

Study design

1780 Paul, K.,Dittrichova, J.,Papousek, H. Infant feeding behavior: development in patterns and motivation. Dev Psychobiol. 1996;29(7):563-76.

Group size

1781 Pavic, I.,Jurkovic, M.,Pastar, Z. Risk factors for acute respiratory tract infections in children. Coll Antropol. 2012;36(2):539-42.

Study design

1782 Pearce, M. S.,Birrell, F. N.,Francis, R. M.,Rawlings, D. J.,Tuck, S. P.,Parker, L. Lifecourse study of bone health at age 49-51 years: the Newcastle thousand families cohort study. J Epidemiol Community Health. 2005;59(6):475-80.

1783 Pearson, Catherine. Study Finds Breastfeeding May Lower Alzheimer's Risk. Inside Childbirth Education. 2013:9-9 1p.

Study design

1784 Peat, J. K. Can asthma be prevented? Evidence from epidemiological studies of children in Australia and New Zealand in the last decade. Clin Study design Exp Allergy. 1998;28(3):261-5.

1785 Peat, J. K.,Allen, J.,Oddy, W.,Webb, K. Breastfeeding and asthma: appraising the controversy. Pediatr Pulmonol. 2003;35(5):331-4.

Study design

1786 Pedersen, C. B.,Zachau-Christiansen, B. Otitis media in Greenland children: acute, chronic and secretory otitis media in three- to eight-yearolds. J Otolaryngol. 1986;15(6):332-5.

1787 Pei, Z.,Heinrich, J.,Fuertes, E.,Flexeder, C.,Hoffmann, B.,Lehmann, I.,Schaaf, B.,von Berg, A.,Koletzko, S. Cesarean delivery and risk of childhood obesity. J Pediatr. 2014;164(5):1068-1073 e2.

1788 Pelayo, L.,Nunez, F. A.,Rojas, L.,Wilke, H.,Furuseth Hansen, E.,Mulder, B.,Gjerde, B.,Robertson, L. Molecular and epidemiological investigations of cryptosporidiosis in Cuban children. Ann Trop Med Parasitol. 2008;102(8):659-69.
Study design

\section{Included for}

systematic reviews not completed

Health status 
1789 Peltzer, K.,Mongkolchati, A.,Satchaiyan, G.,Rajchagool, S.,Pimpak, T. Sociobehavioral factors associated with caries increment: a longitudinal study from 24 to 36 months old children in Thailand. Int J Environ Res Public Health. 2014;11(10):10838-50
Included for systematic reviews not completed

Independent variable Dependent variable

Group size

Dependent variable

Study design

Study design

Study design

Dependent variable

Included for

systematic reviews not completed

Study design

Dependent variable, Health status

Included for systematic reviews not completed

Independent variable

Independent variable A cohort study. Acta Paediatr. 1998;87(6):618-22.

1801 Pesonen, M. Kallio, M. J.,Ranki, A Siimes, M. A. Prolonged exclusive breastfeeding is associated with increased atopic dermatitis: a prospective follow-up study of unselected healthy newborns from birth to age 20 years. Clin Exp Allergy. 2006;36(8):1011-8

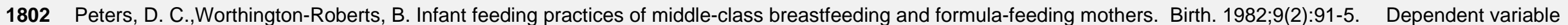

1803 Peters, K. E.,Huang, J.,Vaughn, M. G.,Witko, C. Does breastfeeding contribute to the racial gap in reading and math test scores?. Ann Epidemiol. 2013;23(10):646-51.
Included for

systematic reviews not completed 
1804 Peters, T. J.,Golding, J. The epidemiology of childhood eczema: II. Statistical analyses to identify independent early predictors. Paediatr Perinat Epidemiol. 1987;1(1):80-94.

1805 Petherick, A. Development: Mother's milk: A rich opportunity. Nature. 2010;468(7327):S5-7.

Study design

1806 Petti, S.,Cairella, G., Tarsitani, G. Rampant early childhood dental decay: an example from Italy. J Public Health Dent. 2000;60(3):159-66.

Study design

1807 Pettitt, D. J.,Forman, M. R.,Hanson, R. L.,Knowler, W. C.,Bennett, P. H.. Breastfeeding and incidence of non-insulin-dependent diabetes mellitus in Pima Indians. Lancet. 1997;350(9072):166-8.

1808 Pettitt, D. J.,Knowler, W. C. Long-term effects of the intrauterine environment, birth weight, and breast-feeding in Pima Indians. Diabetes Care. 1998;21 Suppl 2:B138-41.

1809 Peyre, H.,Bernard, J. Y.,Forhan, A.,Charles, M. A.,De Agostini, M.,Heude, B.,Ramus, F.,Charles, M. A.,De Agostini, M.,Forhan, A.,Heude, B.,Ducimetière, P.,Kaminski, M.,Saurel-Cubizolles, M. J.,Dargent, P.,Fritel, X.,Larroque, B.,Lelong, N.,Marchand, L.,Nabet, C.,Annesi-Maesano, I.,Slama, R.,Goua, V.,Magnin, G.,Hankard, R., Thiebaugeorges, O.,Schweitzer, M.,Foliguet, B.,Job-Spira, N. Predicting changes in language skills between 2 and 3 years in the EDEN mother-child cohort. PeerJ. 2014;2014(1).

1810 Pfluger, M.,Winkler, C.,Hummel, S.,Ziegler, A. G. Early infant diet in children at high risk for type 1 diabetes. Horm Metab Res. 2010;42(2):143-

1811 Picciano, M. F.,Deering, R. H. The influence of feeding regimens on iron status during infancy. Am J Clin Nutr. 1980;33(4):746-53.

Independent variable

1812 Picone, T. A.,Benson, J. D.,Moro, G.,Minoli, I.,Fulconis, F.,Rassin, D. K.,Raiha, N. C. Growth, serum biochemistries, and amino acids of term infants fed formulas with amino acid and protein concentrations similar to human milk. J Pediatr Gastroenterol Nutr. 1989;9(3):351-60.

Independent variable, Dependent variable

1813 Piemontese, P.,Gianni, M. L.,Braegger, C. P.,Chirico, G.,Gruber, C.,Riedler, J.,Arslanoglu, S., van Stuijvenberg, M.,Boehm, G.,Jelinek, J.,Roggero, $P$. Tolerance and safety evaluation in a large cohort of healthy infants fed an innovative prebiotic formula: a randomized controlled trial. PLoS One. 2011;6(11):e28010.

Included for systematic reviews not completed

1814 Pinho, A. P.,Aerts, D.,Nunes, M. L. Risk factors for sudden infant death syndrome in a developing country. Rev Saude Publica. 2008;42(3):396-

Independent variable 401.

1815 Pinzon-Rondon, A. M.,Aguilera-Otalvaro, P.,Zarate-Ardila, C.,Hoyos-Martinez, A. Acute respiratory infection in children from developing nations: a multi-level study. Paediatr Int Child Health. 2015:2046905515y0000000021.

1816 Pires, S. C.,Giugliani, E. R.,Caramez da Silva, F. Influence of the duration of breastfeeding on quality of muscle function during mastication in preschoolers: a cohort study. BMC Public Health. 2012;12(1):934.

Study design

Included for

systematic reviews not completed

1817 Pirila, S.,Saarinen-Pihkala, U. M., Viljakainen, H.,Turanlahti, M.,Kajosaari, M.,Makitie, O.,Taskinen, M. Breastfeeding and determinants of adult body composition: a prospective study from birth to young adulthood. Horm Res Paediatr. 2012;77(5):281-90.

Included for systematic reviews not completed 
1818 Pirila, S., Taskinen, M.,Viljakainen, H.,Kajosaari, M.,Turanlahti, M.,Saarinen-Pihkala, U. M.,Makitie, O. Infant milk feeding influences adult bone health: a prospective study from birth to 32 years. PLoS One. 2011;6(4):e19068.

Included for systematic reviews not completed

Group size

1819 Pisa 31.

1820 Pisacane, A.,Graziano, L.,Zona, G.,Granata, G.,Dolezalova, H.,Cafiero, M.,Coppola, A.,Scarpellino, B.,Ummarino, M.,Mazzarella, G. Breast feeding and acute lower respiratory infection. Acta Paediatr. 1994;83(7):714-8.

1821 Pivik, R. T.,Andres, A.,Badger, T. M. Diet and gender influences on processing and discrimination of speech sounds in 3- and 6-month-old infants: a developmental ERP study. Dev Sci. 2011;14(4):700-12.

1822 Pivik, R. T.,Andres, A.,Badger, T. M. Effects of diet on early stage cortical perception and discrimination of syllables differing in voice-onset time: a longitudinal ERP study in 3 and 6 month old infants. Brain Lang. 2012;120(1):27-41.

1823 Pivik, R. T.,Andres, A.,Tennal, K. B.,Gu, Y.,Armbya, N.,Cleves, M. A.,Badger, T. M. Infant diet, gender and the normative development of vaga tone and heart period during the first two years of life. Int J Psychophysiol. 2013;90(3):311-20.

1824 Pivik, R. T.,Andres, A.,Tennal, K. B.,Gu, Y.,Cleves, M. A.,Badger, T. M. Infant diet, gender and the development of vagal tone stability during the first two years of life. Int J Psychophysiol. 2015;96(2):104-14.

1825 Pivik, R. T.,Dykman, R. A.,Jing, H.,Gilchrist, J. M.,Badger, T. M. Early infant diet and the omega 3 fatty acid DHA: effects on resting cardiovascular activity and behavioral development during the first half-year of life. Dev Neuropsychol. 2009;34(2):139-58.

1826 Pivik, R. T.,Dykman, R. A.,Jing, H.,Gilchrist, J. M.,Badger, T. M. The influence of infant diet on early developmental changes in processing human voice speech stimuli: ERP variations in breast and milk formula-fed infants at 3 and 6 months after birth. Dev Neuropsychol. 2007;31(3):279-335

1827 Piwoz, E. G.,Creed de Kanashiro, H.,Lopez de Romana, G. L.,Black, R. E.,Brown, K. H. Feeding practices and growth among low-income Peruvian infants: a comparison of internationally-recommended definitions. Int J Epidemiol. 1996;25(1):103-14.

1828 Pizarro, F.,Yip, R.,Dallman, P. R.,Olivares, M.,Hertrampf, E.,Walter, T. Iron status with different infant feeding regimens: relevance to screening and prevention of iron deficiency. J Pediatr. 1991;118(5):687-92.

1829 Plachta-Danielzik, S.,Kehden, B.,Landsberg, B.,Schaffrath Rosario, A.,Kurth, B. M.,Arnold, C.,Graf, C.,Hense, S.,Ahrens, W.,Muller, M. J. Attributable risks for childhood overweight: evidence for limited effectiveness of prevention. Pediatrics. 2012;130(4):e865-71.

1830 Plagemann, A.,Harder, T.,Franke, K.,Kohlhoff, R. Long-term impact of neonatal breast-feeding on body weight and glucose tolerance in children of diabetic mothers. Diabetes Care. 2002;25(1):16-22.

1831 Plagemann, A.,Harder, T.,Kohlhoff, R.,Fahrenkrog, S.,Rodekamp, E.,Franke, K.,Dudenhausen, J. W. Impact of early neonatal breast-feeding on psychomotor and neuropsychological development in children of diabetic mothers. Diabetes Care. 2005;28(3):573-8.
Study design, Health status

Included for

systematic reviews not completed

Included for

systematic reviews not completed

Dependent variable

Dependent variable

Group size

Group size

Independent variable

Study design,

Independent variable

Study design

Independent variable

ndependent variable 
1832 Plagemann, A.,Harder, T.,Rodekamp, E.,Kohlhoff, R. Rapid neonatal weight gain increases risk of childhood overweight in offspring of diabetic mothers. J Perinat Med. 2012;40(5):557-63.

1833 Plenge-Bonig, A.,Soto-Ramirez, N.,Karmaus, W.,Petersen, G.,Davis, S.,Forster, J. Breastfeeding protects against acute gastroenteritis due to rotavirus in infants. Eur J Pediatr. 2010;169(12):1471-6.

1834 Plonka, K. A.,Pukallus, M. L.,Barnett, A. G.,Walsh, L. J.,Holcombe, T. F.,Seow, W. K. A longitudinal study comparing mutans streptococci and lactobacilli colonisation in dentate children aged 6 to 24 months. Caries Res. 2012;46(4):385-93.

1835 Plonka, K. A.,Pukallus, M. L.,Barnett, A. G.,Walsh, L. J.,Holcombe, T. H.,Seow, W. K. Mutans streptococci and lactobacilli colonization in predentate children from the neonatal period to seven months of age. Caries Res. 2012;46(3):213-20.

Independent variable

Study design,

Independent variable

Included for

systematic reviews not completed

Included for

systematic reviews not completed

1836 Podratz, R. O.,Broughton, D. D.,Gustafson, D. H.,Bergstralh, E. J.,Melton, L. J., 3rd. Weight loss and body temperature changes in breast-fed and bottle-fed neonates. Clin Pediatr (Phila). 1986;25(2):73-7.

Included for

systematic reviews not completed

1837 POEMs. Breastfeeding does not decrease risk of asthma and allergy. JAAPA: Journal of the American Academy of Physician Assistants (Haymarket Media, Inc.). 2008;21(1):66-66 1p.

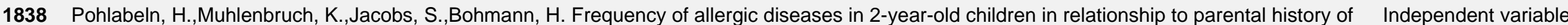
allergy and breastfeeding. J Investig Allergol Clin Immunol. 2010;20(3):195-200.

1839 Poikonen, S.,Puumalainen, T. J.,Kautiainen, H.,Palosuo, T.,Reunala, T.,Turjanmaa, K. Sensitization to turnip rape and oilseed rape in children with atopic dermatitis: a case-control study. Pediatr Allergy Immunol. 2008;19(5):408-11.

1840 Pollock, J. I.. Long-term associations with infant feeding in a clinically advantaged population of babies. Dev Med Child Neurol. 1994;36(5):429-

1841 Pomerance, H. H. Growth in breast-fed children. Hum Biol. 1987;59(4):687-93.

Independent variable

1842 Porro, E.,Indinnimeo, L.,Antognoni, G.,Midulla, F.,Criscione, S. Early wheezing and breast feeding. J Asthma. 1993;30(1):23-8.

Dependent variable

1843 Portela, D. S.,Vieira, T. O.,Matos, S. M.,de Oliveira, N. F.,Vieira, G. O. Maternal obesity, environmental factors, cesarean delivery and breastfeeding as determinants of overweight and obesity in children: results from a cohort. BMC Pregnancy Childbirth. 2015;15:94.

1844 Portoian-Shuhaiber, S.,Al-Rashied, A. A. Feeding practices and electrolyte disturbances among infants admitted with acute diarrhoea--a survey in Kuwait. J Trop Pediatr. 1986;32(4):168-73.

1845 Potera, Carol. Prolonged Bottle Feeding Raises Childhood Obesity Risk: Weaning around one year is recommended. American Journal of Nursing. 2011;111(8):17-17 1p.

1846 Potter, A.,Lumley, J.,Watson, L. The 'new' risk factors for SIDS: is there an association with the ethnic and place of birth differences in incidence in Victoria, Australia?. Early Hum Dev. 1996;45(1-2):119-31.

Independent variable

Independent variable

\section{Included for}

systematic reviews not

completed

Study design, Health

status

Study design

Independent variable, Dependent variable 
1848 Potur, A. H.,Kalmaz, N. An investigation into feeding errors of 0-4-month-old infants. J Trop Pediatr. 1995;41(2):120-2.

Study design

1849 Poysa, L. Atopy in children with and without a family history of atopy. II. Skin reactivity. Acta Paediatr Scand. 1989;78(6):902-6.

Independent variable

1850 Poysa, L.,Korppi, M.,Remes, K.,Juntunen-Backman, K. Atopy in childhood and diet in infancy. A nine-year follow-up study. I. Clinical manifestations. Allergy Proc. 1991;12(2):107-11.

1851 Poysa, L.,Korppi, M.,Remes, K.,Juntunen-Backman, K. Predictive value of IgE levels in infancy. Acta Paediatr Scand. 1990;79(10):970-2.

Study design

Dependent variable

1852 Poysa, L.,Remes, K.,Korppi, M.,Juntunen-Backman, K. Atopy in children with and without a family history of atopy. I. Clinical manifestations, with Group size special reference to diet in infancy. Acta Paediatr Scand. 1989;78(6):896-901.

1853 Prado-Montes de Oca, E.,Garcia-Vargas, A.,Lozano-Inocencio, R.,Gallegos-Arreola, M. P.,Sandoval-Ramirez, L.,Davalos-Rodriguez, N. O.,Figuera, L. E. Association of beta-defensin 1 single nucleotide polymorphisms with atopic dermatitis. Int Arch Allergy Immunol. 2007;142(3):211-8.

1854 Prado-Montes De Oca, E.,García-Vargas, A.,Lozano-Inocencio, R.,Gallegos-Arreola, M. P.,Sandoval-Ramírez, L.,Dávalos-Rodríguez, N. O.,Figuera, L. E. Association of $\beta$-defensin 1 single nucleotide polymorphisms with atopic dermatitis. International Archives of Allergy and Immunology. 2007;142(3):211-218.

1855 Prathanee, B.,Purdy, S. C.,Thinkhamrop, B.,Chaimay, B.,Ruangdaraganon, N.,Mo-suwan, L.,Phuphaibul, R. Early language delay and predictive factors in children aged 2 years. J Med Assoc Thai. 2009;92(7):930-8.

Study design

Study design

Included for

systematic reviews not completed

1856 Pratt, H. F. Breastfeeding and eczema. Early Hum Dev. 1984;9(3):283-90.

Independent variable

1857 Prentice, P.,Koulman, A.,Matthews, L.,Acerini, C. L.,Ong, K. K.,Dunger, D. B. Lipidomic analyses, breast- and formula-feeding, and growth in infants. J Pediatr. 2015;166(2):276-81 e6.

Included for systematic reviews not completed

1858 Price, Gareth. A test of temperament. Midwives. 2011;14(4):13-13 1p.

Study design

1859 Priego, T.,Sanchez, J.,Pico, C.,Ahrens, W.,Bammann, K.,De Henauw, S.,Fraterman, A.,Iacoviello, L.,Lissner, L.,Molnar, D.,Moreno, L. A.,Siani, A.,Tornaritis, M.,Veidebaum, T.,Palou, A. Influence of breastfeeding on blood-cell transcript-based biomarkers of health in children. Pediatr

Study design Obes. $2014 ; 9(6): 463-70$

1860 Priya, N. Gayathri,Victoria, L. Eilean,Porkodi, A.,Eaton, Linda,Doorenbos, Ardith. Effectiveness of Breastfeeding Empowerment Programme among Primigravidae. Communicating Nursing Research. 2013;46:579-579 1p.

1861 Procter, S. B.,Holcomb, C. A. Breastfeeding duration and childhood overweight among low-income children in Kansas, 1998-2002. Am J Public Health. 2008;98(1):106-10.

Country

Included for systematic reviews not completed 
1862 Prodam, F.,Roccio, M.,Trovato, L.,Ricotti, R.,Moia, S.,Giglione, E.,Petri, A.,Walker, G. E.,Bellone, S.,Bona, G. Adiponectin oligomers are similarly distributed in adequate-for-gestational-age obese children irrespective of feeding in their first year. Pediatr Res. 2015;77(6):808-13.

1863 Project report. Results and policy implications of the cross-national investigation: Rethinking Infant Nutrition Policies under changing SocioEconomic Conditions. Acta Paediatr Scand Suppl. 1984;314:1-61.

1864 Prolonged breast feeding reduces later cardiovascular risk. Arch Dis Child. 2009;94(11):882.

Study design,

Dependent variable

1865 Promoting breast-feeding: fewer infections than in bottle-fed babies. Very few contraindications to breast-feeding. Prescrire international. 2009;18(102):178.

1866 Protective effect of breast milk against pneumonia is greatest for young infants. Bmj. 1999;318(7194):C

Study design

1867 Puccio, G.,Cajozzo, C.,Meli, F.,Rochat, F.,Grathwohl, D.,Steenhout, P. Clinical evaluation of a new starter formula for infants containing live Bifidobacterium longum BL999 and prebiotics. Nutrition. 2007;23(1):1-8.

1868 Pugh, L. C.,Milligan, R. A. Nursing intervention to increase the duration of breastfeeding. Appl Nurs Res. 1998;11(4):190-4.

Dependent variable

1869 Pugh, L. C.,Milligan, R. A.,Frick, K. D.,Spatz, D.,Bronner, Y. Breastfeeding duration, costs, and benefits of a support program for low-income breastfeeding women. Birth. 2002;29(2):95-100.

1870 Puig, C.,Sunyer, J.,Garcia-Algar, O.,Munoz, L.,Pacifici, R.,Pichini, S.,Vall, O. Incidence and risk factors of lower respiratory tract illnesses during infancy in a Mediterranean birth cohort. Acta Paediatr. 2008;97(10):1406-11.

Group size

Included for systematic reviews not completed

1871 Pukander J,Luotonen J,Timonen M,Karma P. Risk factors affecting the occurrence of acute otitis media among 2-3-year-old urban children Acta Otolaryngol. 1985;100:260-5.

Included for systematic reviews not completed

1872 Pukander, J. Acute otitis media among rural children in Finland. Int J Pediatr Otorhinolaryngol. 1982;4(4):325-32.

Included for systematic reviews not completed

1873 Pullan, C. R.,Toms, G. L.,Martin, A. J.,Gardner, P. S.,Webb, J. K.,Appleton, D. R. Breast-feeding and respiratory syncytial virus infection. Br Med J. 1980;281(6247):1034-6.

Included for systematic reviews not completed

1874 Purssell, E. A topic in 10 questions: Gastrointestinal infections from a nutritional perspective. J Fam Health Care. 2012;22(1):28-9.

Study design

1875 Putet, G.,Labaune, J. M.,Mace, K.,Steenhout, P.,Grathwohl, D.,Raverot, V.,Morel, Y.,Picaud, J. C. Effect of dietary protein on plasma insulin-like growth factor-1, growth, and body composition in healthy term infants: a randomised, double-blind, controlled trial (Early Protein and Obesity in Childhood (EPOCH) study). Br J Nutr. 2015:1-14.

Included for systematic reviews not completed

1876 Putra, S. T.,Mansyur, M.,Sastroasmoro, S. Effects of duration of breastfeeding during infancy on vascular dysfunction in adolescents. Acta Med Study design, Country Indones. 2015;47(1):24-30 
1877 Qudsia, F.,Saboor, M.,Khosa, S. M.,Ayub, Q.,Moinuddin,. Comparative analysis of serum iron, serum ferritin and red cell folate levels among breast fed, fortified milk and cow's milk fed infants. Pakistan Journal of Medical Sciences. 2015;31(3):706-709.

1878 Queiroz, V. A.,Assis, A. M.,Pinheiro, S. M.,Ribeiro, H. C., Jr. Predictors of linear growth in the first year of life of a prospective cohort of full term children with normal birth weight. J Pediatr (Rio J). 2012;88(1):79-86.

1879 Quialey, M. A.,Cumberland, P.,Cowden, J. M.,Rodrigues, L. C. How protective is breast feeding against diarrhoeal disease in infants in 1990s England? A case-control study. Archives of Disease in Childhood. 2006;91(3):245-250.

Independent variable

Included for

systematic reviews not completed

1880 Quigley, M. A.,Hockley, C.,Carson, C.,Kelly, Y.,Renfrew, M. J.,Sacker, A. Breastfeeding is associated with improved child cognitive

Included for development: a population-based cohort study. J Pediatr. 2012;160(1):25-32.

systematic reviews not completed

1881 Quigley, M. A.,Kelly, Y. J.,Sacker, A. Breastfeeding and hospitalization for diarrheal and respiratory infection in the United Kingdom Millennium

Study design Cohort Study. Pediatrics. 2007;119(4):e837-42.

1882 Quigley, M. A.,Kelly, Y. J.,Sacker, A. Infant feeding, solid foods and hospitalisation in the first 8 months after birth. Arch Dis Child. 2009;94(2):148-50

1883 Quinn, P. J.,O'Callaghan, M.,Williams, G. M.,Najman, J. M.,Andersen, M. J.,Bor, W. The effect of breastfeeding on child development at 5 years: a cohort study. J Paediatr Child Health. 2001;37(5):465-9.

1884 Quinonez, R.,Santos, R. G.,Wilson, S.,Cross, H. The relationship between child temperament and early childhood caries. Pediatr Dent. 2001;23(1):5-10

1885 Quiroga, M.,Oviedo, P.,Chinen, I.,Pegels, E.,Husulak, E.,Binztein, N.,Rivas, M.,Schiavoni, L., Vergara, M. Asymptomatic infections by diarrheagenic Escherichia coli in children from Misiones, Argentina, during the first twenty months of their lives. Rev Inst Med Trop Sao Paulo. 2000;42(1):9-15.

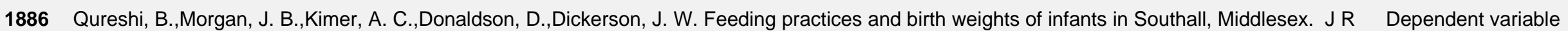
Soc Health. 1988;108(3):77-80.

1887 Rabiei, S. The Association of Nutrition Style through the First 2 Years of Life with Type 1 Diabetes Mellitus and Some of the Other Effective Factors in 2-15 Years Old Children. Iranian Journal of Endocrinology \& Metabolism. 2011;13(1):9-113 105p.

1888 Radlovic, N. P.,Mladenovic, M. M.,Lekovic, Z. M.,Stojsic, Z. M.,Radlovic, V. N. Influence of early feeding practices on celiac disease in infants. Croat Med J. 2010;51(5):417-22

1889 Rady, H. I.,Samir, H.,Tomerak, R.,Gaafar, M. Occult blood in stool in exclusively formula fed infants versus exclusively breast fed infants in the first six months of life. Egyptian Pediatric Association Gazette. 2014;62(1):8-13.

1890 Raftowicz-Wójcik, K.,Matthews-Brzozowska, T.,Kawala, B.,Antoszewska, J. The effects of breast feeding on occlusion in primary dentition. Advances in Clinical and Experimental Medicine. 2011;20(3):371-375

Independent variable

Included for

systematic reviews not completed

Study design

Included for

systematic reviews not

completed

Language

Independent variable Health status

Study design, Country

Study design 
1891 Rahman, M.,Roy, S. K.,Ali, M.,Mitra, A. K.,Alam, A. N.,Akbar, M. S. Maternal nutritional status as a determinant of child health. J Trop Pediatr. 1993;39(2):86-8

1892 Raiha, N. C.,Fazzolari-Nesci, A.,Boehm, G. Taurine supplementation prevents hyperaminoacidemia in growing term infants fed high-protein cow's milk formula. Acta Paediatr. 1996;85(12):1403-7.

1893 Raiha, N. C.,Fazzolari-Nesci, A.,Cajozzo, C.,Puccio, G.,Monestier, A.,Moro, G.,Minoli, I.,Haschke-Becher, E.,Bachmann, C.,Van't Hof, M.,Carrie Fassler, A. L.,Haschke, F. Whey predominant, whey modified infant formula with protein/energy ratio of $1.8 \mathrm{~g} / 100 \mathrm{kcal}$ : adequate and safe for term infants from birth to four months. J Pediatr Gastroenterol Nutr. 2002;35(3):275-81.

1894 Räihä, N.,Fazzolari, A.,Cayozzo, C.,Puccio, G.,Minoli, I.,Moro, G.,Monestier, A.,Haschke-Becher, E.,Carrié, A. L.,Haschke, F. Infant formula with $\quad$ Group size $1.8 \mathrm{~g}$ Protein/100 Kcal is adequate and safe from birth to 4 months. Revue Medicale Libanaise. 2002;14(1):29-31.

1895 Raiha, N.,Minoli, I.,Moro, G. Milk protein intake in the term infant. I. Metabolic responses and effects on growth. Acta Paediatr Scand. $1986 ; 75(6): 881-6$

1896 Raisler, J.,Alexander, C.,O'Campo, P. Breast-feeding and infant illness: a dose-response relationship?. Am J Public Health. 1999;89(1):25-30. status

1897 Ramezani, G. H.,Norozi, A.,Valael, N. The prevalence of nursing caries in 18 to 60 months old children in Qazvin. J Indian Soc Pedod Prev Dent. 2003;21(1):19-26.

1898 Ramirez, G. B.,Pagulayan, O.,Akagi, H.,Francisco Rivera, A.,Lee, L. V.,Berroya, A., Vince Cruz, M. C., Casintahan, D. Tagum study II: follow-up Country study at two years of age after prenatal exposure to mercury. Pediatrics. 2003;111(3):e289-95.

1899 Ramirez-Silva, I.,Rivera, J.,Martorell, R.,Stein, A.,Ramakrishnan, U. Breastfeeding at 3 months is associated with lower risk of adiposity and lipid Study design metabolism alterations at $4 \mathrm{y}$ of age. Annals of nutrition \& metabolism. 2013;63:774-5.

1900 Ramos, D. E. Breastfeeding: a bridge to addressing disparities in obesity and health. Breastfeed Med. 2012;7(5):354-7.

Study design

1901 Ramos-Gomez, F. J.,Tomar, S. L.,Ellison, J.,Artiga, N.,Sintes, J.,Vicuna, G. Assessment of early childhood caries and dietary habits in a population of migrant Hispanic children in Stockton, California. ASDC J Dent Child. 1999;66(6):395-403, 366.

1902 Rannan-Eliya, R. P.,Hossain, S. M.,Anuranga, C.,Wickramasinghe, R.,Jayatissa, R.,Abeykoon, A. T. Trends and determinants of childhood stunting and underweight in Sri Lanka. Ceylon Med J. 2013;58(1):10-8.

1903 Ransome, O. J.,Chalmers, B.,Herman, A. A.,Reinach, S. G. Infant feeding in an urban community. S Afr Med J. 1988;74(8):393-5.

Study design

1904 Rao, M. R.,Hediger, M. L.,Levine, R. J.,Naficy, A. B.,Vik, T. Effect of breastfeeding on cognitive development of infants born small for gestational age. Acta Paediatr. 2002;91(3):267-74.

1905 Rao, S.,Kanade, A. N. Prolonged breast-feeding and malnutrition among rural Indian children below 3 years of age. Eur J Clin Nutr. 1992;46(3):187-95.

1906 Rao, S.,Rajpathak, V. Breastfeeding and weaning practices in relation to nutritional status of infants. Indian pediatrics. 1992;29(12):1533-1539.

Study design

Study design, Country

Independent variable,

Health status

Country

Country 
1910 Rathnayake, K. M.,Satchithananthan, A.,Mahamithawa, S.,Jayawardena, R. Early life predictors of preschool overweight and obesity: a casecontrol study in Sri Lanka. BMC Public Health. 2013;13:994.

1911 Ravelli, A. C.,van der Meulen, J. H.,Osmond, C.,Barker, D. J.,Bleker, O. P. Infant feeding and adult glucose tolerance, lipid profile, blood pressure, and obesity. Arch Dis Child. 2000;82(3):248-52.

1912 Rawashdeh, M. O.,Khalil, B.,Raweily, E. Celiac disease in Arabs. J Pediatr Gastroenterol Nutr. 1996;23(4):415-8.

Study design, Independent variable

Independent variable

Study design, Independent variable, Health status

1913 Ray G. Infant feeding. Psychology of choice. Nurs Mirror. 1985;160:25-8.

Study design

1914 RC currents. Children breast-fed by asthmatic mothers at risk, says study. AARC Times. 2001;25(4):70-70 1p. Study design

1915 Reading, R. Effects of prolonged and exclusive breastfeeding on child behavior and maternal adjustment: evidence from a large, randomized trial..Kramer MS, Fombonne E, Igumnov S, Vanilovich L, Matush L, Mironova E, Bogdanovich N, Tremblay RE, Chalmers B, Zhang X \& Platt RW for the PROBIT study group (2008) Pediatrics, 121, E435-40. Child: Care, Health \& Development. 2008;34(4):547-547 1p.

1916 Rebhan, B.,Kohlhuber, M.,Schwegler, U.,Fromme, H.,Abou-Dakn, M.,Koletzko, B. V. Breastfeeding duration and exclusivity associated with infants' health and growth: data from a prospective cohort study in Bavaria, Germany. Acta Paediatr. 2009;98(6):974-80.

1917 Regnault, N.,Botton, J.,Blanc, L.,Hankard, R.,Forhan, A.,Goua, V.,Thiebaugeorges, O.,Kaminski, M.,Heude, B.,Charles, M. A. Determinants of neonatal weight loss in term-infants: specific association with pre-pregnancy maternal body mass index and infant feeding mode. Arch Dis Child Fetal Neonatal Ed. 2011;96(3):F217-22.

1918 Regnault, N.,Botton, J.,Forhan, A.,Hankard, R.,Thiebaugeorges, O.,Hillier, T. A.,Kaminski, M.,Heude, B.,Charles, M. A. Determinants of early ponderal and statural growth in full-term infants in the EDEN mother-child cohort study. Am J Clin Nutr. 2010;92(3):594-602.

Study design

Included for

systematic reviews not completed

Included for

systematic reviews not completed

Included for systematic reviews not completed

1919 Regnault,N,Botton,J,Forhan,A,Hankard,R,Thiebaugeorges,O,Hillier,T, A.,Kaminski,M,Heude,B,Charles,M, A. Determinants of early ponderal and Duplicate statural growth in full-term infants in the EDEN mother-child cohort study. Am J Clin Nutr. 2010;92(3):594-602.

1920 Reid, A. Infant feeding and post-neonatal mortality in Derbyshire, England, in the early twentieth century. Popul Stud (Camb). 2002;56(2):15166.

1921 Renn, M. Baby milk: is breast second best?. Nurs Times. 1987;83(6):19-20.

Study design 
1923 Renz, H.,Brehler, C.,Petzoldt, S.,Prinz, H.,Rieger, C. H. Breast feeding modifies production of SIgA cow's milk-antibodies in infants. Acta Paediatr Scand. 1991;80(2):149-54.

1924 Reyes Romagosa, D. E.,Paneque Gamboa, M. R.,Almeida Muniz, Y.,Quesada Oliva, L. M.,Escalona Oliva, D.,Torres Naranjo, S. Risk factors associated with deforming oral habits in children aged 5 to 11: a case-control study. Medwave. 2014;14(2):e5927.

1925 Reyes, H.,Perez-Cuevas, R.,Salmeron, J.,Tome, P.,Guiscafre, H.,Gutierrez, G. Infant mortality due to acute respiratory infections: the influence of primary care processes. Health Policy Plan. 1997;12(3):214-23.

1926 Reyes, H.,Perez-Cuevas, R.,Sandoval, A.,Castillo, R.,Santos, J. I.,Doubova, S. V.,Gutierrez, G. The family as a determinant of stunting in children living in conditions of extreme poverty: a case-control study. BMC Public Health. 2004;4:57.

1927 Reyes, M.,Hoyos, V.,Martinez, S. M.,Lozoff, B.,Castillo, M.,Burrows, R.,Blanco, E.,Gahagan, S. Satiety responsiveness and eating behavior among Chilean adolescents and the role of breastfeeding. Int J Obes (Lond). 2014;38(4):552-7.

1928 Reynolds, D.,Hennessy, E.,Polek, E. Is breastfeeding in infancy predictive of child mental well-being and protective against obesity at 9 years of Study design age?. Child Care Health Dev. 2014;40(6):882-90.

1929 Rhodes C. The benefits of breast-feeding. J Pract Nurs. 1982;32:19-21, 54-5.

Study design

1930 Ribadeau-Dumas, B. Human milk. Endeavour. 1983;7(2):80-7.

Study design

1931 Ribas-Fito, N.,Cardo, E.,Sala, M.,Eulalia de Muga, M.,Mazon, C.,Verdu, A.,Kogevinas, M.,Grimalt, J. O.,Sunyer, J. Breastfeeding, exposure to organochlorine compounds, and neurodevelopment in infants. Pediatrics. 2003;111(5 Pt 1):e580-5.

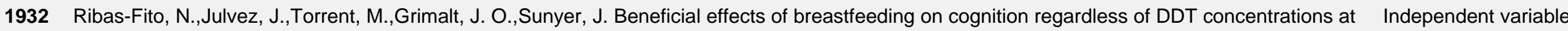
birth. Am J Epidemiol. 2007;166(10):1198-202.

1933 Ricco, R. G.,Nogueira-de-Almeida, C. A.,Del Ciampo, L. A.,Daneluzzi, J. C.,Ferlin, M. L.,Muccillo, G. Growth of exclusively breast-fed infants from a poor urban population. Arch Latinoam Nutr. 2001;51(2):122-6.

Included for

systematic reviews not completed

1934 Richards, M.,Hardy, R.,Wadsworth, M. E. Long-term effects of breast-feeding in a national birth cohort: educational attainment and midlife cognitive function. Public Health Nutr. 2002;5(5):631-5.

Included for systematic reviews not completed

1935 Richards, M.,Wadsworth, M.,Rahimi-Foroushani, A.,Hardy, R.,Kuh, D.,Paul, A. Infant nutrition and cognitive development in the first offspring of Independent variable a national UK birth cohort. Dev Med Child Neurol. 1998;40(3):163-7.

1936 Richardson, B. D.,Cleaton-Jones, P. E.,McInnes, P. M.,Rantsho, J. M. Infant feeding practices and nursing bottle caries. ASDC J Dent Child. 1981;48(6):423-9.

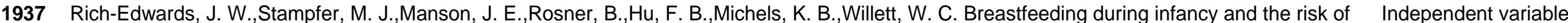
cardiovascular disease in adulthood. Epidemiology. 2004;15(5):550-6. 
1938 Richman, D.,Dixon, S. Comparative study of Cambodian, Hmong, and Caucasian infant and maternal perinatal profiles. J Nurse Midwifery. 1985;30(6):313-9.

1939 Rigby, A. S.,Sanderson, C.,Desforges, M. F.,Lindsay, G.,Hall, D. M. The infant index: a new outcome measure for pre-school children's services. J Public Health Med. 1999;21(2):172-8.

Included for systematic reviews not completed

1940 Rigo, J.,Salle, B. L.,Cavero, E.,Richard, P.,Putet, G.,Senterre, J. Plasma amino acid and protein concentrations in infants fed human milk or a whey protein hydrolysate formula during the first month of life. Acta Paediatr. 1994;83(2):127-31.

Group size

1941 Rigo, J.,Salle, B. L.,Picaud, J. C.,Putet, G.,Senterre, J. Nutritional evaluation of protein hydrolysate formulas. Eur J Clin Nutr. 1995;49 Suppl 1:S26-38.

1942 Riordan, J.,Countryman, B. A. Basics of breastfeeding. Part IV: Preparation for breastfeeding and early optimal functioning. JOGN Nurs. 1980;9(5):277-83

1943 Rios-Castillo, I.,Cerezo, S.,Corvalan, C.,Martinez, M.,Kain, J. Risk factors during the prenatal period and the first year of life associated with overweight in 7-year-old low-income Chilean children. Matern Child Nutr. 2015;11(4):595-605.

1944 Riva, V.,Battaglia, M.,Nobile, M.,Cattaneo, F.,Lazazzera, C.,Mascheretti, S.,Giorda, R.,Merette, C.,Emond, C.,Maziade, M.,Marino, C. GRIN2B predicts attention problems among disadvantaged children. Eur Child Adolesc Psychiatry. 2015;24(7):827-36.

1945 Roberts AK. Prospects for further approximation of infant formulae to human milk. Midwife Health Visit Community Nurse. 1987;23:140-6.

Dependent variable

1946 Roberts, C. C.,Chan, G. M.,Folland, D.,Rayburn, C.,Jackson, R. Adequate bone mineralization in breast-fed infants. J Pediatr. 1981;99(2):1926.

1947 Roberts, D. W. Growth of breast fed and bottle fed infants. N Z Med J. 1980;92(664):45-6.

Group size

Included for

systematic reviews not completed

1948 Roberts, G. J. Is breast feeding a possible cause of dental caries?. J Dent. 1982;10(4):346-52.

Study design

1949 Robinson, M.,Oddy, W. H.,Li, J.,Kendall, G. E.,de Klerk, N. H.,Silburn, S. R.,Zubrick, S. R.,Newnham, J. P.,Stanley, F. J.,Mattes, E. Pre- and Included for postnatal influences on preschool mental health: a large-scale cohort study. J Child Psychol Psychiatry. 2008;49(10):1118-28.

systematic reviews not completed

1950 Robinson, S. M.,Crozier, S. R.,Harvey, N. C.,Barton, B. D.,Law, C. M.,Godfrey, K. M.,Cooper, C.,Inskip, H. M. Modifiable early-life risk factors for childhood adiposity and overweight: an analysis of their combined impact and potential for prevention. Am J Clin Nutr. 2015;101(2):368-75.

Included for systematic reviews not completed

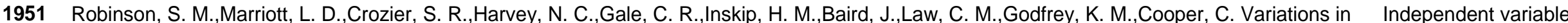
infant feeding practice are associated with body composition in childhood: a prospective cohort study. J Clin Endocrinol Metab. 2009;94(8):2799-805. 
1952 Rochat, F.,Cherbut, C.,Barclay, D.,Puccio, G.,Fazzolari-Nesci, A.,Grathwohl, D.,Haschke, F. A whey-predominant formula induces fecal microbiota similar to that found in breast-fed infants. Nutrition Research. 2007;27(12):735-740.

1953 Roche, A. F.,Guo, S.,Siervogel, R. M.,Khamis, H. J.,Chandra, R. K. Growth comparison of breast-fed and formula-fed infants. Can J Public Health. 1993;84(2):132-5.

1954 Rodekamp, E.,Harder, T.,Kohlhoff, R.,Dudenhausen, J. W.,Plagemann, A. Impact of breast-feeding on psychomotor and neuropsychological development in children of diabetic mothers: role of the late neonatal period. J Perinat Med. 2006;34(6):490-6.

1955 Rodriguez Martinez, C.,Sossa, M.,Goss, C. H. Factors associated with severe disease in a population of asthmatic children of Bogota, Colombia. Study design J Asthma. 2008;45(2):141-7.

1956 Rodriguez-Lopez, M.,Osorio, L.,Acosta-Rojas, R.,Figueras, J.,Cruz-Lemini, M.,Figueras, F.,Bijnens, B.,Gratacos, E.,Crispi, F. Influence of breastfeeding and postnatal nutrition on cardiovascular remodeling induced by fetal growth restriction. Pediatr Res. 2015.

Independent variable,

Health status

1957 Roelants, M.,Hauspie, R.,Hoppenbrouwers, K. Breastfeeding, growth and growth standards: Performance of the WHO growth standards for Independent variable monitoring growth of Belgian children. Ann Hum Biol. 2010;37(1):2-9.

1958 Rogan, W. J.,Gladen, B. C. Breast-feeding and cognitive development. Early Hum Dev. 1993;31(3):181-93.

Included for systematic reviews not completed

1959 Rolland-Cachera, M. F.,Peneau, S. Assessment of growth: variations according to references and growth parameters used. Am J Clin Nutr.

Study design 2011;94(6 Suppl):1794S-1798S

1960 Romano, A. M. Longer duration of breastfeeding is associated with lower risk of type-2 diabetes (abst; commentary). Journal of Perinatal Education. 2006;15(2):54-55 2p

1961 Romero, C. C.,Scavone Jr, H.,Garib, D. G.,Cotrim-Ferreira, F. A.,Ferreira, I. R. Breastfeeding and non-nutritive sucking patterns related to the prevalence of anterior open bite in primary dentition. Journal of Applied Oral Science. 2011;19(2):161-168.

1962 Romieu, I.,Werneck, G.,Ruiz Velasco, S.,White, M.,Hernandez, M. Breastfeeding and asthma among Brazilian children. J Asthma 2000;37(7):575-83

1963 Rona, R. J.,Smeeton, N. C.,Bustos, P.,Amiga, H.,Diaz, P. V. The early origins hypothesis with an emphasis on growth rate in the first year of life and asthma: A prospective study in Chile. Thorax. 2005;60(7):549-554.

1964 Rose, C. M.,Savage, J. S.,Birch, L. L. Patterns of early dietary exposures have implications for maternal and child weight outcomes. Obesity (Silver Spring). 2016;24(2):430-8

1965 Rosenbauer, J.,Herzig, P.,Kaiser, P.,Giani, G. Early nutrition and risk of Type 1 diabetes mellitus--a nationwide case-control study in preschool children. Exp Clin Endocrinol Diabetes. 2007;115(8):502-8.

1966 Rosenberg, M. Breast-feeding and infant mortality in Norway 1860-1930. J Biosoc Sci. 1989;21(3):335-48.

Study design

Study design

Study design

Dependent variable

Study design,

Independent variable

Redundant data

ndependent variable 
1967 Rosenblatt, A.,Zarzar, P. The prevalence of early childhood caries in 12- to 36-month-old children in Recife, Brazil. ASDC J Dent Child. 2002;69(3):319-24, 236

1968 Rosenblatt, W. H.,Brown, E. G. The nutritional status of breast-fed infants in a rural Peruvian community. J Trop Pediatr. $1988 ; 34(6): 319-22$.

Study design

1969 Rossiter, J. C. Breast-feeding, the better option: getting the message across. World Health Forum. 1993;14(3):316-8.

Study design

1970 Rossiter, M. D.,Colapinto, C. K.,Khan, M. K.,Mclsaac, J. L.,Williams, P. L.,Kirk, S. F.,Veugelers, P. J. Breast, Formula and Combination Feeding Study design in Relation to Childhood Obesity in Nova Scotia, Canada. Matern Child Health J. 2015;19(9):2048-56.

1971 Rossiter, M. D.,Evers, S. E. Infant feeding practices and children's weight status. Can J Diet Pract Res. 2013;74(3):107-13.

Independent variable

Dependent variable

1972 Roszkowska, R.,Taranta-Janusz, K.,Tenderenda-Banasiuk, E.,Wasilewska, A. Increased circulating inflammatory markers may indicate that

Study design, formula-fed children are at risk of atherosclerosis. Acta Paediatr. 2014;103(8):e354-8.

Dependent variable

1973 Roszkowska, R.,Taranta-Janusz, K.,Tenderenda-Banasiuk, E.,Wasilewska, A. The effects of breastfeeding on serum asymmetric dimethylarginine levels and body composition in children. Breastfeed Med. 2015;10:38-44.

1974 Rousseau, E. H.,Lescop, J. N.,Fontaine, S.,Lambert, J.,Roy, C. C. Influence of cultural and environmental factors on breast-feeding. Can Med Assoc J. 1982;127(8):701-4.

1975 Routi, T.,Ronnemaa, T.,Viikari, J. S.,Leino, A.,Valimaki, I. A.,Simell, O. G. Tracking of serum lipoprotein (a) concentration and its contribution to serum cholesterol values in children from 7 to 36 months of age in the STRIP Baby Study. Special Turku Coronary Risk Factor Intervention Project for Babies. Ann Med. 1997;29(6):541-7. Clin Nutr. 1985;41(2 Suppl):459-63.

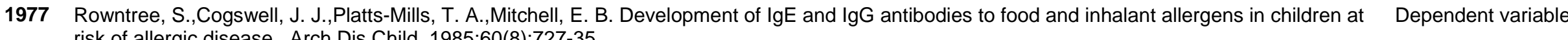
risk of allergic disease. Arch Dis Child. 1985;60(8):727-35

1978 Rubin, D. H.,Leventhal, J. M.,Krasilnikoff, P. A.,Kuo, H. S.,Jekel, J. F.,Weile, B.,Levee, A.,Kurzon, M.,Berget, A. Relationship between infant feeding and infectious illness: a prospective study of infants during the first year of life. Pediatrics. 1990;85(4):464-71.

1979 Rudant, J.,Lightfoot, T.,Urayama, K. Y.,Petridou, E.,Dockerty, J. D.,Magnani, C.,Milne, E.,Spector, L. G.,Ashton, L. J.,Dessypris, N.,Kang, A. Y.,Miller, M.,Rondelli, R.,Simpson, J.,Stiakaki, E.,Orsi, L.,Roman, E.,Metayer, C.,Infante-Rivard, C.,Clavel, J. Childhood acute lymphoblastic leukemia and indicators of early immune stimulation: A childhood leukemia international consortium study. American Journal of Epidemiology. 2015;181(8):549-562.

1980 Rudant, J.,Orsi, L.,Bonaventure, A.,Goujon-Bellec, S.,Baruchel, A.,Petit, A.,Bertrand, Y.,Nelken, B.,Pasquet, M.,Michel, G.,Saumet, L.,Chastagner, P.,Ducassou, S.,Reguerre, Y.,Hemon, D., Clavel, J. ARID5B, IKZF1 and non-genetic factors in the etiology of childhood acute lymphoblastic leukemia: the ESCALE study. PLoS One. 2015;10(3):e0121348.

1981 Rudnicka, A. R.,Owen, C. G.,Strachan, D. P. The effect of breastfeeding on cardiorespiratory risk factors in adult life. Pediatrics. 2007;119(5):e1107-15.

Study design

Dependent variable

Independent variable Dependent variable

Study design

Independent variable

Study design

Independent variable Redundant data

Independent variable 

2004;93(4):482-6.

1983 Ruijsbroek, A.,Wijga, A. H.,Kerkhof, M.,Koppelman, G. H.,Smit, H. A.,Droomers, M.. The development of socio-economic health differences in childhood: results of the Dutch longitudinal PIAMA birth cohort. BMC Public Health. 2011;11(\#issue\#):225.

Included for systematic reviews not completed

Language

1984 Ruiz-Charles, M. G.,Castillo-Rendón, R.,Bermúdez-Felizardo, F. Risk factors associated to bronchiolitis in infants less than two years of age. Revista de Investigacion Clinica. 2002;54(2):125-132.

1985 Ruiz-Palacios, G. M.,Calva, J. J.,Pickering, L. K.,Lopez-Vidal, Y.,Volkow, P.,Pezzarossi, H.,West, M. S. Protection of breast-fed infants against Campylobacter diarrhea by antibodies in human milk. J Pediatr. 1990;116(5):707-13.

1986 Rullo, V. E.,Arruda, L. K.,Cardoso, M. R.,Valente, V.,Zampolo, A. S.,Nobrega, F.,Naspitz, C. K.,Sole, D. Respiratory infection, exposure to mouse allergen and breastfeeding: role in recurrent wheezing in early life. Int Arch Allergy Immunol. 2009;150(2):172-8.

1987 Rusconi, F.,Galassi, C.,Corbo, G. M.,Forastiere, F.,Biggeri, A.,Ciccone, G.,Renzoni, E.,Camerlengo, A.,Bugiani, M.,Dalmasso, P.,Faggiano, F.,Volante, T. F.,Magnani, C.,Natale, P.,Piccioni, P.,Bisanti, L., Gianelle, V.,Sideri, S.,Piffer, S.,Filippetti, F.,Nava, E.,Biocca, M.,Canossa,

E.,Cavalchi, B.,Cervino, D.,Cattani, S.,De'Munari, E.,Deserti, M.,Ferro, S.,Fortezza, F.,Frigo, F.,Martini, M.,Mazzali, P.,Paterlini, L.,Sogni,

R.,Zanini, M.,Romagna, E.,Chellini, E.,Agati, L.,Barletta, E.,Bini, G.,Bini, M.,Chetoni, L.,Grechi, D.,Costantini, A. S.,Sestini, P.,Viegi, G.,Agabiti, N.,Dell'Orco, V.,Mallone, S.,Micera, C.,Palermo, P.,Pallotti, G.,Piras, C.,Pistelli, R.,Salera, E.,Argentini, D.,Chiarucci, G. Risk factors for early, persistent, and late-onset wheezing in young children. American Journal of Respiratory and Critical Care Medicine. 1999;160(5 I):1617-1622.

1988 Rush, E. C.,Paterson, J.,Obolonkin, V. V.,Puniani, K. Application of the 2006 WHO growth standard from birth to 4 years to Pacific Island children. Int J Obes (Lond). 2008;32(3):567-72.

1989 Rush, E.,Gao, W.,Funaki-Tahifote, M.,Ngamata, R.,Matenga-Smith, T.,Cassidy, M.,Paterson, J. Birth weight and growth trajectory to six years in Pacific children. Int J Pediatr Obes. 2010;5(2):192-9.

1990 Russo, R. M.,Patel, R.,Laude, T. A.,Rajkumar, S. V.,Gururaj, V. J. Infant feeding practices by ethno-cultural grouping. J Med Soc N J. $1981 ; 78(11): 737-40$

1991 Rutishauser, I. H.,McKay, H. M.,Wahlqvist, M. L. Does breast feeding have nutritional advantages over bottle feeding?. Aust Fam Physician. 1982;11(4):249-50, 252-3, 255-6

1992 Ruuska, T. Occurrence of acute diarrhea in atopic and nonatopic infants: the role of prolonged breast-feeding. J Pediatr Gastroenterol Nutr. 1992;14(1):27-33.

1993 Ruuska, T.,Vesikari, T. A prospective study of acute diarrhoea in Finnish children from birth to 2 1/2 years of age. Acta Paediatr Scand. 1991;80(5):500-7.

1994 Ruys, J. H.,de Jonge, G. A.,Brand, R.,Engelberts, A. C.,Semmekrot, B. A. Bed-sharing in the first four months of life: a risk factor for sudden infant death. Acta Paediatr. 2007;96(10):1399-403.

\section{Group size}

Independent variable

Study design

Included for systematic reviews not completed

Study design,

Dependent variable

Study design

Included for

systematic reviews not completed

Group size

Study design 
1995 Rylander, E.,Pershagen, G.,Eriksson, M.,Nordvall, L. Parental smoking and other risk factors for wheezing bronchitis in children. Eur J

1996 Rzehak, P.,Sausenthaler, S.,Koletzko, S.,Bauer, C. P. Schaaf, B.,von Berg, A.,Berdel, D.,Borte, M.,Herbarth, O.,Kramer, U.,Fenske,

N.,Wichmann, H. E.,Heinrich, J. Period-specific growth, overweight and modification by breastfeeding in the GINI and LISA birth cohorts up to age 6 years. Eur J Epidemiol. 2009;24(8):449-67.

1997 Rzehak, P.,Sausenthaler, S.,Koletzko, S.,Reinhardt, D.,von Berg, A.,Kramer, U.,Berdel, D.,Bollrath, C.,Grubl, A.,Bauer, C. P.,Wichmann, H. E.,Heinrich, J. Short- and long-term effects of feeding hydrolyzed protein infant formulas on growth at $<$ or $=6 \mathrm{y}$ of age: results from the German Infant Nutritional Intervention Study. Am J Clin Nutr. 2009;89(6):1846-56.

1998 Saarinen, K. M.,Juntunen-Backman, K.,Jarvenpaa, A. L.,Klemetti, P.,Kuitunen, P.,Lope, L., Renlund, M.,Siivola, M.,Vaarala, O.,Savilahti, E. Breast-feeding and the development of cows' milk protein allergy. Adv Exp Med Biol. 2000;478:121-30.

1999 Saarinen, K. M.,Juntunen-Backman, K.,Jarvenpaa, A. L.,Kuitunen, P.,Lope, L.,Renlund, M.,Siivola, M.,Savilahti, E. Supplementary feeding in maternity hospitals and the risk of cow's milk allergy: A prospective study of 6209 infants. J Allergy Clin Immunol. 1999;104(2 Pt 1):457-61.

2000 Saarinen, K. M.,Savilahti, E. Infant feeding patterns affect the subsequent immunological features in cow's milk allergy. Clin Exp Allergy. 2000;30(3):400-6

2001 Saarinen, U. M. Prolonged breast feeding as prophylaxis for recurrent otitis media. Acta Paediatr Scand. 1982;71(4):567-71.

2002 Saarinen, U. M.,Kajosaari, M. Breastfeeding as prophylaxis against atopic disease: prospective follow-up study until 17 years old . Lancet. 1995;346(8982):1065-9

2003 Saarinen, U. M.,Kajosaari, M.,Backman, A. Birch pollen allergy in children. Role of milk feeding during the first birch season of life. Allergy. 1982;37(5):345-50.

2004 Sabanayagam, C.,Shankar, A.,Chong, Y. S.,Wong, T. Y.,Saw, S. M. Breast-feeding and overweight in Singapore school children. Pediatr Int. 2009;51(5):650-6.

2005 Sabuncuoglu, O.,Orengul, C.,Bikmazer, A.,Kaynar, S. Y. Breastfeeding and parafunctional oral habits in children with and without attentiondeficit/hyperactivity disorder. Breastfeed Med. 2014;9(5):244-50.

2006 Sacker, A.,Kelly, Y.,Iacovou, M.,Cable, N.,Bartley, M. Breast feeding and intergenerational social mobility: what are the mechanisms?. Arch Dis Child. 2013;98(9):666-71.

2007 Sacker, A.,Quigley, M. A.,Kelly, Y. J. Breastfeeding and developmental delay: findings from the millennium cohort study. Pediatrics. 2006;118(3):e682-9.

2008 Sadeharju, K.,Knip, M., Virtanen, S. M.,Savilahti, E., Tauriainen, S., Koskela, P.,Akerblom, H. K.,Hyoty, H. Maternal antibodies in breast milk protect the child from enterovirus infections. Pediatrics. 2007;119(5):941-6. 
2009 Saeed, M.,Waseem, Q.,Ali Shair, Q.,Omonogun, B. A.,Al Husein, A. Vitamin D deficiency rickets in Maternity and Children's Hospital, Najran, Saudi Arabia. Pakistan Paediatric Journal. 2008;32(3):145-148.

2010 Sahakyan, A.,Armenian, H. K.,Breitscheidel, L., Thompson, M. E.,Enokyan, G. Feeding practices of babies and the development of atopic dermatitis in children after 12 months of age in Armenia: Is there a signal?. European Journal of Epidemiology. 2006;21(9):723-725.

2011 Sahin, F.,Camurdan, A. D.,Camurdan, M. O.,Olmez, A.,Oznurhan, F.,Beyazova, U. Factors affecting the timing of teething in healthy Turkish infants: a prospective cohort study. Int J Paediatr Dent. 2008;18(4):262-6.

2012 Sajjad, A., Tharner, A.,Kiefte-de Jong, J. C.,Jaddoe, V. V.,Hofman, A.,Verhulst, F. C.,Franco, O. H.,Tiemeier, H.,Roza, S. J. Breastfeeding duration and non-verbal IQ in children. J Epidemiol Community Health. 2015;69(8):775-81.

2013 Saki Malehi, A.,Hajizadeh, E.,Ahmadi, K.,Kholdi, N. Modeling the recurrent failure to thrive in less than two-year children: recurrent events survival analysis. J Res Health Sci. 2014;14(1):96-9.

2014 Salah, M.,Abdel-Aziz, M.,Al-Farok, A.,Jebrini, A. Recurrent acute otitis media in infants: analysis of risk factors. Int J Pediatr Otorhinolaryngol. 2013;77(10):1665-9.

2015 Salariya, E. M. Breast versus bottle feeding. Nutr Health. 1993;9(1):33-6

2017 Salariya, E. M.,Robertson, C. M. Relationships between baby feeding types and patterns, gut transit time of meconium and the incidence of neonatal jaundice. Midwifery. 1993;9(4):235-42.

Dependent variable

Included for

systematic reviews not completed

2018 Salazar, J. C.,Daly, K. A.,Giebink, G. S.,Lindgren, B. R.,Liebeler, C. L.,Meland, M.,Le, C. T. Low cord blood pneumococcal immunoglobulin G (IgG) antibodies predict early onset acute otitis media in infancy. Am J Epidemiol. 1997;145(11):1048-56.

Independent variable

2019 Salim, S.,Farquharson, J.,Arneil, G. C.,Cockburn, F.,Forbes, G. I.,Logan, R. W.,Sherlock, J. C.,Wilson, T. S. Dietary copper intake in artificially fed infants. Arch Dis Child. 1986;61(11):1068-75.

Included for

systematic reviews not completed

2020 Salmenpera, L.,Perheentupa, J.,Siimes, M. A. Exclusively breast-fed healthy infants grow slower than reference infants. Pediatr Res. Independent variable 1985;19(3):307-12

2021 Salmenpera, L.,Perheentupa, J.,Siimes, M. A.,Adrian, T. E.,Bloom, S. R.,Aynsley-Green, A. Effects of feeding regimen on blood glucose levels and plasma concentrations of pancreatic hormones and gut regulatory peptides at 9 months of age: comparison between infants fed with milk formula and infants exclusively breast-fed from birth. J Pediatr Gastroenterol Nutr. 1988;7(5):651-6.

2022 Salmon, T. G., Jr. Early childhood caries: a private practitioner's perspective. Pediatr Dent. 1997;19(1):63-4. 

project. Special Turku coronary Risk factor Intervention Project for children. Acta Paediatr. 1999;88(5):505-12.

2024 Salsberry, P. J.,Reagan, P. B. Dynamics of early childhood overweight. Pediatrics. 2005;116(6):1329-38.

Included for

systematic reviews not completed

Included for systematic reviews not completed 2007;30(3):297-307

2026 Salvioli, G. P.,Faldella, G.,Alessandroni, R.,Lanari, M.,Di Turi, R. P. Iron nutrition and iron status changes in Italian infants in the last decade Ann Ist Super Sanita. 1995;31(4):455-9.

2027 Samarakkody, D.,Fernando, D.,McClure, R.,Perera, H.,De Silva, H. Prevalence of externalizing behavior problems in Sri Lankan preschool children: birth, childhood, and sociodemographic risk factors. Soc Psychiatry Psychiatr Epidemiol. 2012;47(5):757-62.

2028 Sanchez-Molins, M.,Grau Carbo, J.,Lischeid Gaig, C.,Ustrell Torrent, J. M. Comparative study of the craniofacial growth depending on the type of lactation received. Eur J Paediatr Dent. 2010;11(2):87-92.

2029 Sánchez-Uribe, E.,Esparza-Aguilar, M.,Gastañaduy, P. A.,Desai, R.,Patel, M.,Richardson, V. Risk factors associated with rotavirus gastroenteritis during a community outbreak in Chiapas, Mexico during the postvaccination Era. Journal of the Pediatric Infectious Diseases Society. 2013;2(1):15-20.

2030 Sanchez-Valverde, F.,Gil, F.,Martinez, D.,Fernandez, B.,Aznal, E.,Oscoz, M.,Olivera, J. E. The impact of caesarean delivery and type of feeding on cow's milk allergy in infants and subsequent development of allergic march in childhood. Allergy. 2009;64(6):884-9.

2031 Sandstrom, O.,Lonnerdal, B.,Graverholt, G.,Hernell, O. Effects of alpha-lactalbumin-enriched formula containing different concentrations of glycomacropeptide on infant nutrition. Am J Clin Nutr. 2008;87(4):921-8.

2032 Sanger, R. G.,Bystrom, E. B. Breast feeding: does it affect oral facial growth?. Dent Hyg (Chic). 1982;56(6):44-7.

Study design

Study design

Independent variable

Independent variable

Health status

Group size

Study design

2033 Sanin, L. H.,Gonzalez-Cossio, T.,Romieu, I.,Peterson, K. E.,Ruiz, S.,Palazuelos, E.,Hernandez-Avila, M.,Hu, H. Effect of maternal lead burden on infant weight and weight gain at one month of age among breastfed infants. Pediatrics. 2001;107(5):1016-23.

2034 Santorelli, G.,Fairley, L.,Petherick, E. S.,Cabieses, B.,Sahota, P. Ethnic differences in infant feeding practices and their relationship with BMI at 3 years of age - results from the Born in Bradford birth cohort study. Br J Nutr. 2014;111(10):1891-7.

2035 Santos, C. A.,Strina, A.,Amorim, L. D.,Genser, B.,Assis, A. M.,Prado, M. S.,Barreto, M. L. Individual and contextual determinants of the duration of diarrhoeal episodes in preschool children: a longitudinal study in an urban setting. Epidemiol Infect. 2012;140(4):689-96.

2036 Santos, I. S.,Matijasevich, A.,Assuncao, M. C.,Valle, N. C.,Horta, B. L.,Goncalves, H. D.,Gigante, D. P.,Martines, J. C.,Pelto, G.,Victora, C. G. Promotion of Weight Gain in Early Childhood Does Not Increase Metabolic Risk in Adolescents: A 15-Year Follow-Up of a Cluster-Randomized Controlled Trial. J Nutr. 2015;145(12):2749-55.
Study design

ncluded for systematic reviews not completed

Health status

Independent variable 
2037 Santos, I. S.,Matijasevich, A.,Barros, A. J.,Albernaz, E. P.,Domingues, M. R.,Valle, N. C.,Malta, D. C.,Gorgot, L. R.,Barros, F. C. Avoidable deaths in the first four years of life among children in the 2004 Pelotas (Brazil) birth cohort study. Cad Saude Publica. 2011;27 Suppl 2:S185-97.
Included for systematic reviews not completed

Independent variable

Study design

Study design

Study design

Included for

systematic reviews not completed

Study design

Redundant data

2044 Saukkonen, T.,Virtanen, S. M.,Karppinen, M.,Reijonen, H.,Ilonen, J.,Räsänen, L.,. Significance of cow's milk protein antibodies as risk factor for childhood IDDM: Interactions with dietary cow's milk intake and HLA-DQB1 genotype. Diabetologia. 1998;41(1):72-78.

2045 Savilahti, E.,Salmenpera, L.,Tainio, V. M.,Halme, H.,Perheentupa, J.,Siimes, M. A. Prolonged exclusive breast-feeding results in low serum concentrations of immunoglobulin G, A and M. Acta Paediatr Scand. 1987;76(1):1-6.

Independent variable

Dependent variable

Dependent variable

Independent variable and development of atopy by age 4. Pediatr Res. 2005;58(6):1300-5.

2047 Savilahti, E.,Tainio, V. M.,Salmenpera, L.,Arjomaa, P.,Kallio, M.,Perheentupa, J.,Siimes, M. A. Levels of IgA and cow milk antibodies in breast milk vs. the development of atopy in children. Low colostral IgA associated with cow milk allergy. Adv Exp Med Biol. 1991;310:417-25.

2048 Savilahti, E.,Tainio, V. M.,Salmenpera, L.,Siimes, M. A.,Perheentupa, J. Prolonged exclusive breast feeding and heredity as determinants in infantile atopy. Arch Dis Child. 1987;62(3):269-73.

Included for

systematic reviews not completed

Included for systematic reviews not completed

Group size

Dependent variable

2051 Savino, F.,Oggero, R.,Prino, A.,Mostert, M.. Hypoantigenic (HA) milk formula and blood cholesterol level in infants at 3 months of age. Acta Paediatr. 1997;86(9):1003-5. 
2054 Sawley, L. Breast is best. Nurs Mirror. 1985;160(2):15-9.

Study design

2055 Sawley, L. Infant feeding. Nursing (Lond). 1989;3(39):18-23.

Study design

2056 Say, G. N.,Karabekiroglu, K.,Babadagi, Z.,Yuce, M. Maternal stress and perinatal features in autism \& attention deficit/ hyperactivity disorder Pediatr Int. 2015.

Included for systematic reviews not completed

2057 Sayegh, A.,Dini, E. L.,Holt, R. D.,Bedi, R. Caries prevalence and patterns and their relationship to social class, infant feeding and oral hygiene in Study design 4-5-year-old children in Amman, Jordan. Community Dent Health. 2002;19(3):144-51.

2058 Sayegh, A.,Dini, E. L.,Holt, R. D.,Bedi, R. Oral health, sociodemographic factors, dietary and oral hygiene practices in Jordanian children. J Dent. 2005;33(5):379-88.

2059 Sayyed, T.,Kandil, M.,Bashir, O.,Alnaser, H. The relationship between term pre-eclampsia and the risk of early childhood caries. J Matern Feta Neonatal Med. 2014;27(1):62-5.

2060 Scaglioni, S.,Agostoni, C.,Notaris, R. D.,Radaelli, G.,Radice, N.,Valenti, M.,Giovannini, M.,Riva, E. Early macronutrient intake and overweight at five years of age. Int J Obes Relat Metab Disord. 2000;24(6):777-81.

Study design

Group size

Included for

systematic reviews not completed

2061 Scalabrin, D.,Mitmesser, S.,Birch, E.,Khoury, J.,Bean, J.,Harris, C.,Berseth, C. Lower incidence and less recurrence of allergic manifestations is observed in children who received docosahexaenoic acid/arachidonic acid in infancy via breast milk or supplemented formula. Allergy: European Journal of Allergy and Clinical Immunology. Conference: 30th Congress of the European Academy of Allergy and Clinical Immunology Istanbul Turkey. Conference Start: 20110611 Conference End: 20110615. Conference Publication: (var.pagings). 2011;66(94):711.

2062 Scariati, P. D.,Grummer-Strawn, L. M.,Fein, S. B. A longitudinal analysis of infant morbidity and the extent of breastfeeding in the United States. Pediatrics. 1997;99(6):E5.

2063 Scariati, P. D.,Grummer-Strawn, L. M.,Fein, S. B.,Yip, R. Risk of diarrhea related to iron content of infant formula: lack of evidence to support the

Independent variable use of low-iron formula as a supplement for breastfed infants. Pediatrics. 1997;99(3):E2.

2064 Scarlett D,Cargill M,Lyn-Sue J,Richardson S,McCaw-Binns A. Breastfeeding prevalence among six-week-old infants at University Hospital of the West Indies. West Indian Med J. 1996;45:14-7.

2065 Scerri, C.,Savona-Ventura, C. Early metabolic imprinting as a determinant of childhood obesity. International Journal of Diabetes Mellitus. 2010;2(3):175-178.

2066 Schach, B.,Haight, M. Colic and food allergy in the breastfed infant: is it possible for an exclusively breastfed infant to suffer from food allergy?. J Hum Lact. 2002;18(1):50-2.

Study design

Study design

Study design 
2067 Schack-Nielsen, L.,Michaelsen, K. F.,Mortensen, E. L.,Sorensen, T. I.,Reinisch, J. M. Is duration of breastfeeding influencing the risk of obesity in adult males?. Adv Exp Med Biol. 2004;554:383-5.

2068 Schack-Nielsen, L.,Molgaard, C.,Larsen, D.,Martyn, C., Michaelsen, K. F. Arterial compliance in 10-year-old children in relation to breastfeeding. Adv Exp Med Biol. 2004;554:391-3.

2069 Schack-Nielsen, L., Sorensen, Tla,Mortensen, E. L., Michaelsen, K. F. Late introduction of complementary feeding, rather than duration of breastfeeding, may protect against adult overweight. Am J Clin Nutr. 2010;91(3):619-27.

2070 Schaefer-Graf, U. M.,Hartmann, R.,Pawliczak, J.,Passow, D.,Abou-Dakn, M.,Vetter, K.,Kordonouri, O. Association of breast-feeding and early childhood overweight in children from mothers with gestational diabetes mellitus. Diabetes Care. 2006;29(5):1105-7.

2071 Scheer, B. Caries in children--the dietary factor. Middle East Dent Oral Health. 1985(3):20-2.

Study design

Redundant data

Included for

systematic reviews not completed

Study design

Study design

2072 Scheiwe, A.,Hardy, R.,Watt, R. G. Four-year follow-up of a randomized controlled trial of a social support intervention on infant feeding practices. Matern Child Nutr. 2010;6(4):328-37.

2073 Schellscheidt, J.,Ott, A.,Jorch, G. Epidemiological features of sudden infant death after a German intervention campaign in 1992. Eur J Pediatr. 1997;156(8):655-60.

Study design, Independent variable

Included for

systematic reviews not completed

2074 Scherdel, P.,Botton, J.,Rolland-Cachera, M. F.,Leger, J.,Pele, F.,Ancel, P. Y.,Simon, C., Castetbon, K., Salanave, B., Thibault, H.,Lioret, S.,Peneau, S.,Gusto, G.,Charles, M. A.,Heude, B. Should the WHO growth charts be used in France?. PLoS One. 2015;10(3):e0120806.

Study design, Independent variable

2075 Schilithz, A. O.,Kale, P. L.,Gama, S. G.,Nobre, F. F. Risk groups in children under six months of age using self-organizing maps. Comput Methods Programs Biomed. 2014;115(1):1-10.

Study design,

Independent variable

2076 Schluter, P. J.,Durward, C.,Cartwright, S.,Paterson, J. Maternal self-report of oral health in 4-year-old Pacific children from South Auckland, New Zealand: findings from the Pacific Islands Families Study. J Public Health Dent. 2007;67(2):69-77.

Included for

systematic reviews not completed

2077 Schluter, P. J.,Ford, R. P.,Mitchell, E. A., Taylor, B. J. Residential mobility and sudden infant death syndrome. J Paediatr Child Health. 1998;34(5):432-7.

2078 Schluter, P. J.,Paterson, J.,Percival, T. Infant care practices associated with sudden infant death syndrome: findings from the Pacific Islands Families study. J Paediatr Child Health. 2007;43(5):388-93.

Independent variable

Study design

2079 Schmidt BJ. Breast-feeding and infant morbidity and mortality in developing countries. J Pediatr Gastroenterol Nutr. 1983;2 Suppl 1:S127-30.

Study design

2080 Schmitt, J.,Romanos, M. Prenatal and perinatal risk factors for attention-deficit/hyperactivity disorder. Arch Pediatr Adolesc Med. 2012;166(11):1074-5.

2081 Schnitzer, M. E.,Moodie, E. E.,Platt, R. W. Targeted maximum likelihood estimation for marginal time-dependent treatment effects under density misspecification. Biostatistics. 2013;14(1):1-14. 
2082 Schnitzer, M. E.,van der Laan, M. J.,Moodie, E. E.,Platt, R. W. EFFECT OF BREASTFEEDING ON GASTROINTESTINAL INFECTION IN INFANTS: A TARGETED MAXIMUM LIKELIHOOD APPROACH FOR CLUSTERED LONGITUDINAL DATA. Ann AppI Stat. 2014;8(2):703-725.
Included for

systematic reviews not completed

Dependent variable

Independent variable Public Health Nutr. 2009;12(12):2309-16.

2084 Schoetzau, A.,Filipiak-Pittroff, B.,Franke, K.,Koletzko, S.,Von Berg, A.,Gruebl, A.,Bauer, C. P.,Berdel, D.,Reinhardt, D.,Wichmann, H. E. Effect of exclusive breast-feeding and early solid food avoidance on the incidence of atopic dermatitis in high-risk infants at 1 year of age. Pediatr Allergy Immunol. 2002;13(4):234-42.

2085 Scholtens, S.,Brunekreef, B.,Smit, H. A.,Gast, G. C.,Hoekstra, M. O.,de Jongste, J. C.,Postma, D. S.,Gerritsen, J.,Seidell, J. C.,Wijga, A. H. Do differences in childhood diet explain the reduced overweight risk in breastfed children?. Obesity (Silver Spring). 2008;16(11):2498-503.

2086 Scholtens, S.,Gehring, U.,Brunekreef, B.,Smit, H. A.,de Jongste, J. C.,Kerkhof, M.,Gerritsen, J.,Wijga, A. H. Breastfeeding, weight gain in infancy, and overweight at seven years of age: the prevention and incidence of asthma and mite allergy birth cohort study. Am J Epidemiol. $2007 ; 165(8): 919-26$

2087 Schroeder, N.,Rushovich, B.,Bartlett, E.,Sharma, S.,Gittelsohn, J.,Caballero, B. Early Obesity Prevention: A Randomized Trial of a PracticeBased Intervention in 0-24-Month Infants. J Obes. 2015;2015:795859.

2088 Schwartz, R.,Vigo, A.,de Oliveira, L. D.,Justo Giugliani, E. R. The Effect of a Pro-Breastfeeding and Healthy Complementary Feeding Intervention Targeting Adolescent Mothers and Grandmothers on Growth and Prevalence of Overweight of Preschool Children. PLoS One. 2015;10(7):e0131884

2089 Schwartzbaum, J. A.,George, S. L.,Pratt, C. B.,Davis, B. An exploratory study of environmental and medical factors potentially related to childhood cancer. Med Pediatr Oncol. 1991;19(2):115-21.

2090 Schwarz, T. Bottle or breast. The first big decision. Nurs Times. 1990;86(35):63-5.

Included for

systematic reviews not completed

Included for systematic reviews not completed

Independent variable

Included for

systematic reviews not completed

Study design

Study design

Study design

Dependent variable

Independent variable

2092 Sclavos S,Porter S,Kim Seow W. Future caries development in children with nursing bottle caries. J Pedod. 1988;13:1-10.

Included for

systematic reviews not completed

Study design

2094 Scott, F. W.,Kolb, H. Dietary intervention for diabetes prevention in the neonate. Diabetes Metab Rev. 1998;14(1):106.

Study design

2095 Scott, J. A.,Ng, S. Y.,Cobiac, L. The relationship between breastfeeding and weight status in a national sample of Australian children and adolescents. BMC Public Health. 2012;12:107. 
2097 Seach, K. A.,Dharmage, S. C.,Lowe, A. J.,Dixon, J. B. Delayed introduction of solid feeding reduces child overweight and obesity at 10 years. Int J Obes (Lond). 2010;34(10):1475-9.

Included for systematic reviews not completed

2098 Seal, N.,Broome, M. E. Prepregnancy Body Mass Index and Feeding Practices in Relation to Infants' Growth. J Nurse Pract. 2013;9(5).

2099 Sears, M. R.,Greene, J. M.,Willan, A. R.,Taylor, D. R.,Flannery, E. M.,Cowan, J. O.,Herbison, G. P.,Poulton, R. Long-term relation between breastfeeding and development of atopy and asthma in children and young adults: a longitudinal study. Lancet. 2002;360(9337):901-7.

2100 Seethalakshmi,Rao, K. M. No substitute to mother's milk. Nurs J India. 1985;76(2):48-9.

2101 Seipel, M. M.,Shafer, K. The effect of prenatal and postnatal care on childhood obesity. Soc Work. 2013;58(3):241-52.

Study design

Independent variable

Study design

Included for

systematic reviews not completed

Country 2007;11(1-2):13-16.

2103 Serino, R. J.,Gold, S. B. Infant and early childhood oral health care. N Y State Dent J. 1997;63(2):34-5.

Study design

2104 Serva, V.,Karim, H.,Ebrahim, G. J. Breast-feeding and the urban poor in developing countries. J Trop Pediatr. 1986;32(3):127-9.

Dependent variable

2105 Seske, L. M.,Merhar, S. L.,Haberman, B. E. Late-Onset Hypoglycemia in Term Newborns With Poor Breastfeeding. Hosp Pediatr. 2015;5(9):501-4

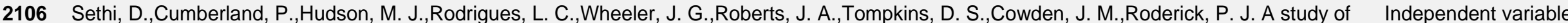
infectious intestinal disease in England: risk factors associated with group A rotavirus in children. Epidemiol Infect. 2001;126(1):63-70.

2107 Sethi, V.,Kashyap, S.,Seth, V. Effect of nutrition education of mothers on infant feeding practices. Indian J Pediatr. 2003;70(6):463-6.

Country

2108 Sezer, R. G.,Aydemir, G.,Akcan, A. B.,Bayoglu, D. S.,Guran, T.,Bozaykut, A. Effect of breastfeeding on serum zinc levels and growth in healthy infants. Breastfeed Med. 2013;8:159-63.

2109 Shaaban, K. M.,Hamadnalla, I. The effect of duration of breast feeding on the occurrence of acute otitis media in children under three years. East Afr Med J. 1993;70(10):632-4.

2110 Shalofsky, Teresa. Telephone peer counselling of breastfeeding among WIC participants: a randomized controlled trial. MIDIRS Midwifery Digest. 2015;25(1):97-98 2p.

2111 Shamir, R.,Nganga, A.,Berkowitz, D.,Diamond, E.,Lischinsky, S.,Lombardo, D.,Shehadeh, N. Serum levels of bile salt-stimulated lipase and breast feeding. J Pediatr Endocrinol Metab. 2003;16(9):1289-94
Study design

Country

Peer review

Group size 
2113 Shariff, A. H.,Sazlina, S. G.,Shamsul, A. S. Obesity among urban primary schoolchildren. Journal of Health and Translational Medicine. Study design 2007;10(1):17-20.

2114 Sharifzadeh, G. R.,Namakin, K.,Mehrjoofard, H. An epidemiological study on infant mortatity and factors affecting it in rural areas of Birjand, Iran. Iranian Journal of Pediatrics. 2008;18(4):335-342.

Included for

systematic reviews not completed

2115 Sharma, S.,Sood, M.,Sood, A. Environmental risk factors in relation to childhood asthma in rural area. Current Pediatric Research. Country 2011;15(1):29-32.

2116 Shaternikov, V. A.,Fateeva, E. M.,Chernikov, M. N. Protein nutrition in early infancy and subsequent periods: its effect on further development. Bibl Nutr Dieta. 1982(31):95-111.

2117 Shearrer, G. E.,Whaley, S. E.,Miller, S. J.,House, B. T.,Held, T.,Davis, J. N. Association of gestational diabetes and breastfeeding on obesity prevalence in predominately Hispanic low-income youth. Pediatr Obes. 2015;10(3):165-71.

2118 Shehadeh, N.,Weitzer-Kish, H.,Shamir, R.,Shihab, S.,Weiss, R. Impact of early postnatal weight gain and feeding patterns on body mass index in adolescence. J Pediatr Endocrinol Metab. 2008;21(1):9-15.

Study design

Study design

Included for systematic reviews not completed

2119 Shelton, K. H.,Collishaw, S.,Rice, F. J.,Harold, G. T., Thapar, A. Using a genetically informative design to examine the relationship between breastfeeding and childhood conduct problems. Eur Child Adolesc Psychiatry. 2011;20(11-12):571-9.

Study design

2120 Shepherd, J. Thrush and breastfeeding. Pract Midwife. 2002;5(11):24-7.

Study design

2121 Shepherd, R. W.,Oxborough, D. B.,Holt, T. L.,Thomas, B. J.,Thong, Y. H. Longitudinal study of the body composition of weight gain in exclusively breast-fed and intake-measured whey-based formula-fed infants to age 3 months. J Pediatr Gastroenterol Nutr. 1988;7(5):732-9.

Included for

systematic reviews not completed

2122 Sherlock, R. L.,Synnes, A. R.,Koehoorn, M. Working mothers and early childhood outcomes: lessons from the Canadian National Longitudinal Study on Children and Youth. Early Hum Dev. 2008;84(4):237-42.

Included for systematic reviews not completed

2123 Shi, Y.,De Groh, M.,Morrison, H. Perinatal and early childhood factors for overweight and obesity in young Canadian children. Can J Public Health. 2013;104(1):e69-74.

2124 Shields, B. M.,Knight, B.,Shakespeare, L.,Babrah, J.,Powell, R. J.,Clark, P. M.,Hattersley, A. T. Determinants of insulin concentrations in healthy 1-week-old babies in the community: applications of a bloodspot assay. Early Hum Dev. 2006;82(2):143-8.

Study design

Study design Dependent variable

2125 Shields, L.,Mamun, A. A.,O'Callaghan, M.,Williams, G. M.,Najman, J. M. Breastfeeding and obesity at 21 years: a cohort study. J Clin Nurs. 2010;19(11-12):1612-7.

Included for

systematic reviews not completed 
2127 Shohet, L.,Shahar, E.,Davidson, S. Breast feeding as prophylaxis for atopic eczema: a controlled study of 368 cases. Acta Paediatr Hung.

Independent variable $1985 ; 26(1): 35-9$

2128 Shortridge, K. F.,Lawton, J. W.,Choi, E. K. Protective potential of colostrum and early milk against prospective influenza viruses. J Trop Pediatr. $1990 ; 36(2): 94-5$

2129 Shu, X. O.,Linet, M. S.,Steinbuch, M.,Wen, W. Q.,Buckley, J. D.,Neglia, J. P.,Potter, J. D.,Reaman, G. H.,Robison, L. L. Breast-feeding and risk of childhood acute leukemia. J Natl Cancer Inst. 1999;91(20):1765-72.

2130 Sickles, V. S.,Tuley, R. J.,Bader, P.,Carnaggio, V. A.,Exon, W. J.,Hargett, I. R.,Keathley, S. E.,Wolf, R.,Cordano, A. Growth and tolerance studies of a new infant formula. Clin Pediatr (Phila). 1984;23(11):617-22.

2131 Sidhu, L. S.,Grewal, R.,Bhatnagar, D. P. A study of physical growth in breast-fed and bottle-fed male infants. Indian journal of pediatrics. 1981;48(390):75-79.

2132 Sievers, E.,Clausen, U.,Oldigs, H. D.,Schaub, J. Supplemental feeding in the first days of life - Effects on the recipient infant. Annals of Nutrition and Metabolism. 2002;46(2):62-67.

2133 Sievers, E.,Oldigs, H. D.,Dorner, K.,Schaub, J. Longitudinal zinc balances in breast-fed and formula-fed infants. Acta Paediatr. 1992;81(1):1-6.

2134 Sievers, E.,Schleyerbach, U.,Garbe-Schonberg, D.,Arpe, T.,Schaub, J. Zinc intakes and plasma concentrations in infancy. Adv Exp Med Biol. 2000;478:383-4

2135 Significance of food hypersensitivity in children with atopic dermatitis. Pediatr Dermatol. 1986;3(2):161-74.

Study design,

Dependent variable

Independent variable

Independent variable

Country

Independent variable

Group size

Study design

Study design

2136 Siimes, M. A.,Salmenpera, L.,Perheentupa, J. Exclusive breast-feeding for 9 months: Risk of iron deficiency. Journal of Pediatrics. 1984;104(2):196-199.

2137 Silberman, S. L.,Trubman, A.,Duncan, W. K.,Meydrech, E. F. Prevalence of primary canine hypoplasia of the mandibular teeth. Pediatr Dent. 1991;13(6):356-60

2138 Siltanen, M.,Kajosaari, M.,Poussa, T.,Saarinen, K. M.,Savilahti, E. A dual long-term effect of breastfeeding on atopy in relation to heredity in children at 4 years of age. Allergy. 2003;58(6):524-30

2139 Silva, A. A.,Mehta, Z.,O'Callaghan, F. J. Duration of breast feeding and cognitive function: Population based cohort study. Eur J Epidemiol 2006;21(6):435-41

2140 Silver, D. H. Improvements in the dental health of 3-year-old Hertfordshire children after 8 years. The relationship to social class. Br Dent J. 1982;153(5):179-83.

Independent variable

Study design

Independent variable

Included for

systematic reviews not completed

Study design 


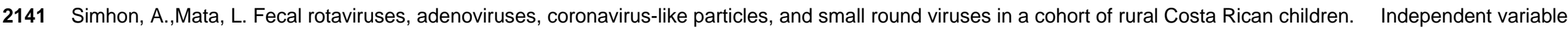
Am J Trop Med Hyg. 1985;34(5):931-6.

2142 Simhon, A.,Mata, L.,Vives, M.,Rivera, L.,Vargas, S.,Ramirez, G.,Lizano, L.,Catarinella, G.,Azofeifa, J. Low endemicity and low pathogenicity of rotaviruses among rural children in Costa Rica. J Infect Dis. 1985;152(6):1134-42.

Study design

Independent variable

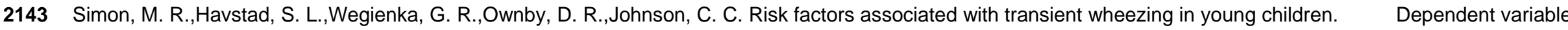
Allergy Asthma Proc. 2008;29(2):161-5.

2144 Sims, D. G., Gardner, P. S.,Weightman, D.,Turner, M. W.,Soothill, J. F. Atopy does not predispose to RSV bronchiolitis or postbronchiolitic wheezing. Br Med J (Clin Res Ed). 1981;282(6282):2086-8.

2145 Singhal, A. Early nutrition and later blood pressure: an experimental approach. Journal of Nutritional \& Environmental Medicine. 2002;12(3):251- Study design 252 2p.

2146 Singhal, A.,Kennedy, K.,Lanigan, J.,Clough, H.,Jenkins, W.,Elias-Jones, A.,Stephenson, T.,Dudek, P.,Lucas, A. Dietary nucleotides and early growth in formula-fed infants: a randomized controlled trial. Pediatrics. 2010;126(4):e946-53.

Included for systematic reviews not completed

2147 Singhal, A.,Lucas, A. Early origins of cardiovascular disease: is there a unifying hypothesis?. Lancet. 2004;363(9421):1642-5.

Study design

2148 Singhi, P.,Singhi, S.,Bhalla, A. K. Growth of term infants in early neonatal period. Indian Pediatr. 1985;22(7):485-91.

Country

2149 Singhi, S.,Singhi, P. Prevention of acute respiratory infections. Indian J Pediatr. 1987;54(2):161-70.

Study design

2150 Singleton, R.,Lescher, R.,Gessner, B. D.,Benson, M.,Bulkow, L.,Rosenfeld, J.,Thomas, T.,Holman, R. C.,Haberling, D.,Bruce, M.,Bartholomew, M.,Tiesinga, J. Rickets and Vitamin D deficiency in Alaska native children. Journal of Pediatric Endocrinology and Metabolism. 2015;28(78):815-823.

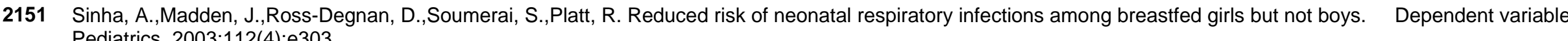
Pediatrics. 2003;112(4):e303.

2152 Sipila, M.,Karma, P.,Pukander, J.,Timonen, M.,Kataja, M. The Bayesian approach to the evaluation of risk factors in acute and recurrent acute otitis media. Acta Otolaryngol. 1988;106(1-2):94-101.

Included for

systematic reviews not completed

2153 Siriaksorn, S.,Suchaitanawanit, S.,Trakultivakorn, M. Allergic rhinitis and immunoglobulin deficiency in preschool children with frequent uppe respiratory illness. Asian Pac J Allergy Immunol. 2011;29(1):73-7.

2154 Sjolin, S.,Hofvander, Y.,Hillervik, C. A prospective study of individual courses of breast feeding. Acta paediatrica Scandinavica. 1979;68:521-9.

2155 Skilton, M. R.,Marks, G. B.,Ayer, J. G.,Garden, F. L., Garnett, S. P.,Harmer, J. A.,Leeder, S. R., Toelle, B. G.,Webb, K.,Baur, L. A.,Celermajer, D. S. Weight gain in infancy and vascular risk factors in later childhood. Pediatrics. 2013;131(6):e1821-8.

Study design

Dependent variable

Included for systematic reviews not completed 
2157 Skrodeniene, E.,Marciulionyte, D.,Padaiga, Z.,Jasinskiene, E.,Sadauskaite-Kuehne, V.,Ludvigsson, J. Environmental risk factors in prediction of

Dependent variable childhood prediabetes. Medicina (Kaunas). 2008;44(1):56-63.

2158 Slabsinskiene E,Milciuviene S,Narbutaite J,Vasiliauskiene I,Andruskeviciene V,Bendoraitiene EA,Saldunaite K. Severe early childhood caries and behavioral risk factors among 3-year-old children in Lithuania. Medicina (Kaunas). 2010;46:135-41.

2159 Slae, M.,Persad, R.,Leung, A. J. T.,Gabr, R.,Brocks, D.,Huynh, H. Q. Role of Environmental Factors in the Development of Pediatric Eosinophilic Esophagitis. Digestive Diseases and Sciences. 2015;60(11):3364-3372.

2160 Slavkin, H. C. Streptococcus mutans, early childhood caries and new opportunities. J Am Dent Assoc. 1999;130(12):1787-92.

Study design

Study design,

Dependent variable

Study design

2161 Slykerman, R. F.,Thompson, J. M.,Becroft, D. M.,Robinson, E.,Pryor, J. E.,Clark, P. M.,Wild, C. J.,Mitchell, E. A. Breastfeeding and intelligence of preschool children. Acta Paediatr. 2005;94(7):832-7

Included for systematic reviews not completed

2162 Smith, D. P. Breastfeeding in the United States. Soc Biol. 1985;32(1-2):53-60.

Study design,

Dependent variable

2163 Smith, R. M.,Smith, P. A.,McKinnon, M.,Gracey, M. Birthweights and growth of infants in five Aboriginal communities. Aust N Z J Public Health. $\quad$ Study design 2000;24(2):124-35

2164 Smithers, L. G.,Golley, R. K.,Brazionis, L.,Emmett, P.,Northstone, K.,Lynch, J. W. Dietary patterns of infants and toddlers are associated with nutrient intakes. Nutrients. 2012;4(8):935-48.

2165 Smithers, L. G.,Golley, R. K.,Mittinty, M. N.,Brazionis, L.,Northstone, K.,Emmett, P.,Lynch, J. W. Dietary patterns at 6, 15 and 24 months of age are associated with IQ at 8 years of age. Eur J Epidemiol. 2012;27(7):525-35.

2166 Smithers, L. G.,Golley, R. K.,Mittinty, M. N.,Brazionis, L.,Northstone, K.,Emmett, P.,Lynch, J. W. Do dietary trajectories between infancy and toddlerhood influence IQ in childhood and adolescence? Results from a prospective birth cohort study. PLoS One. 2013;8(3):e58904.

2167 Socha, P.,Grote, V.,Gruszfeld, D.,Janas, R.,Demmelmair, H.,Closa-Monasterolo, R.,Subias, J. E.,Scaglioni, S.,Verduci, E.,Dain, E.,Langhendries, J. P.,Perrin, E.,Koletzko, B. Milk protein intake, the metabolic-endocrine response, and growth in infancy: data from a randomized clinical trial. Am J Clin Nutr. 2011;94(6 Suppl):1776S-1784S.

2168 Socha, P.,Janas, R.,Dobrzanska, A.,Koletzko, B.,Broekaert, I.,Brasseur, D.,Sengier, A.,Giovannini, M.,Agostoni, C.,Monasterolo, R. C.,Mendezs, G. Insulin like growth factor regulation of body mass in breastfed and milk formula fed infants. Data from the E.U. Childhood Obesity Programme Adv Exp Med Biol. 2005;569:159-63.

2169 Somech, R.,Tal, G.,Gilad, E.,Mandelberg, A.,Tal, A.,Dalal, I. Epidemiologic, socioeconomic, and clinical factors associated with severity of respiratory syncytial virus infection in previously healthy infants. Clin Pediatr (Phila). 2006;45(7):621-7. 
2170 Sommerfelt, K.,Ellertsen, B.,Markestad, T. Low birthweight and neuromotor development: a population based, controlled study. Acta Paediatr. 1996;85(5):604-10.

2171 Sommerfield, T.,Chalmers, J.,Youngson, G.,Heeley, C.,Fleming, M.,Thomson, G. The changing epidemiology of infantile hypertrophic pyloric stenosis in Scotland. Arch Dis Child. 2008;93(12):1007-11.

Independent variable, Health status

Study design Independent variable Health status

Study design a large group of Chinese schoolchildren. J Asthma. 2014;51(3):232-42.

2173 Sonnenschein-van der Voort, A. M.,Jaddoe, V. W.,van der Valk, R. J.,Willemsen, S. P.,Hofman, A.,Moll, H. A.,de Jongste, J. C.,Duijts, L. Duration and exclusiveness of breastfeeding and childhood asthma-related symptoms. Eur Respir J. 2012;39(1):81-9.

2174 Soto-Ramirez, N.,Karmaus, W.,Zhang, H.,Davis, S.,Agarwal, S.,Albergottie, A. Modes of infant feeding and the occurrence of coughing/wheezing in the first year of life. J Hum Lact. 2013;29(1):71-80.

2175 Soylu, H.,Özgen, Ü,Babalioğlu, M.,Aras, Ş,Sazak, S. Iron deficiency and iron deficiency anemia in infants and young children at different socioeconomic groups in Istanbul. Turkish Journal of Haematology. 2001;18(1):19-25.

2176 Specker, B. L.,Beck, A.,Kalkwarf, H.,Ho, M. Randomized trial of varying mineral intake on total body bone mineral accretion during the first year of life. Pediatrics. 1997;99(6):E12.

2177 Spyrides, M. H.,Struchiner, C. J.,Barbosa, M. T., Kac, G. Effect of predominant breastfeeding duration on infant growth: a prospective study using Language nonlinear mixed effect models. J Pediatr (Rio J). 2008;84(3):237-43.

2178 Srivastava, S. P.,Sharma, V. K.,Jha, S. P. Mortality patterns in breast versus artificially fed term babies in early infancy: a longitudinal study Indian Pediatr. 1994;31(11):1393-6.

2179 Stadler, D. D.,Musser, E. D.,Holton, K. F.,Shannon, J.,Nigg, J. T. Recalled Initiation and Duration of Maternal Breastfeeding Among Children with and Without ADHD in a Well Characterized Case-Control Sample. J Abnorm Child Psychol. 2015.

2180 Stahl, M. D.,Guida, D. A. Slow weight gain in the breast-fed infant: management options. Pediatr Nurs. 1984;10(2):117-20, 164.

2181 Stahlberg, M. R. Breast feeding, cow milk feeding, and allergy. Allergy. 1985;40(8):612-5.

2182 Stahlberg, M. R.,Ruuskanen, O.,Virolainen, E. Risk factors for recurrent otitis media. Pediatr Infect Dis. 1986;5(1):30-2.

Dependent variable

Dependent variable

Study design

Independent variable

Country

Study design,

Dependent variable

Study design

Dependent variable

Included for

systematic reviews not completed

2183 Standl, M.,Sausenthaler, S.,Lattka, E.,Koletzko, S.,Bauer, C. P.,Wichmann, H. E., von Berg, A.,Berdel, D.,Kramer, U.,Schaaf, B.,Lehmann, Independent variable I.,Herbarth, O.,Klopp, N.,Koletzko, B.,Heinrich, J. FADS gene cluster modulates the effect of breastfeeding on asthma. Results from the GINIplus and LISAplus studies. Allergy. 2012;67(1):83-90.

2184 Stanfield JP. The influence of malnutrition on development. Practitioner. 1982;226:1929-40.

Study design 
2186 Stanner, S. Is breast best for the heart?. Nutrition Bulletin. 2001;26(3):199-200.

2187 Start smart: healthy weight in early childhood. Issue Brief (Grantmakers Health). 2013:1-14.

Study design

2188 Steady, F. C. Infant feeding in developing countries: combating the multinationals imperative. J Trop Pediatr. 1981;27(4):215-20.

Study design

2190 Steer, C. D Davey Smith, G. Emmett, P. M. Hibbeln, J. R Golding, J. FADS2 polymorphisms modify the effect of breastfeeding on child IQ. PLoS One. 2010;5(7):e11570.

Group size

Included for

systematic reviews not completed

2191 Steichen, J. J.,Tsang, R. C. Bone mineralization and growth in term infants fed soy-based or cow milk-based formula. J Pediatr. 1987;110(5):687-92.

2192 Stein, A. D.,Melgar, P.,Hoddinott, J.,Martorell, R. Cohort profile: The institute of nutrition of central America and Panama (INCAP) nutrition trial cohort study. International Journal of Epidemiology. 2008;37(4):716-720.

2193 Stelmach, I.,Bobrowska-Korzeniowska, M.,Smejda, K.,Majak, P.,Jerzynska, J.,Stelmach, W.,Polanska, K.,Sobala, W.,Krysicka, J.,Hanke, W. Risk factors for the development of atopic dermatitis and early wheeze. Allergy Asthma Proc. 2014;35(5):382-9.

2195 Stenstrom, C., Ingvarsson, L. Otitis-prone children and controls: a study of possible predisposing factors. 1. Heredity, family background and perinatal period. Acta Otolaryngol. 1997;117(1):87-93.

2196 Stepans, M. F. Birthing briefs. Journal of Perinatal Education. 1998;7(1):39-40 2p.

Study design

Study design

Study design,

Independent variable

Included for

systematic reviews not completed

2197 Stevens, F. M.,Egan-Mitchell, B.,Cryan, E.,McCarthy, C. F.,McNicholl, B. Decreasing incidence of coeliac disease. Arch Dis Child. 1987;62(5):465-8.

2198 Stevens, T. Infant nutrition perspectives. Midwives (1995). 1996;109(1300):120.

Study design

Study design

Study design 2199 Stewart, A. J.,Williams, S. M.,Mitchell, E. A., Taylor, B. J.,Ford, R. P.,Allen, E. M. Antenatal and intrapartum factors associated with sudden infant
death syndrome in the New Zealand Cot Death Study. J Paediatr Child Health. 1995;31(5):473-8.

Independent variable

2200 Stoeckel, J. The intervention research approach to child survival. Asia Pac J Public Health. 1992;6(1):40-5.

2201 Stoll, B. J.,Glass, R. I.,Banu, H.,Huq, M. I.,Khan, M. U.,Ahmed, M. Value of stool examination in patients with diarrhoea. Br Med J (Clin Res Ed). Country 1983;286(6383):2037-40. 
2202 Strabelli, T. M. B.,Botura, C. A.,Maciel, M. A.,Mazzutti, C.,Bridi, A.,Freitas, L. P. Socioeconomic profile of children hospitalized by community acquired pneumonia. Acta Scientiarum - Health Sciences. 2013;35(2):175-179.

2203 Strachan, D. P.,Harkins, L. S.,Johnston, I. D.,Anderson, H. R. Childhood antecedents of allergic sensitization in young British adults. J Allergy Clin Immunol. 1997;99(1 Pt 1):6-12.

2204 Strachan, D. P.,Taylor, E. M.,Carpenter, R. G. Family structure, neonatal infection, and hay fever in adolescence. Arch Dis Child. 1996;74(5):422-6.

2205 Strand, T. A., Sharma, P. R.,Gjessing, H. K.,Ulak, M.,Chandyo, R. K.,Adhikari, R. K.,Sommerfelt, H. Risk factors for extended duration of acute diarrhea in young children. PLoS One. 2012;7(5):e36436.

2206 Strbak, V.,Hromadova, M.,Kostalova, L.,Kapellerova, A. Search for optimal age for weaning. Ten-year prospective study. Endocr Regul. 1993;27(4):215-21.

2207 Strimas, J. H.,Chi, D. S. Significance of IgE level in amniotic fluid and cord blood for the prediction of allergy. Ann Allergy. 1988;61(2):133-6.

2208 Strina, A.,Rodrigues, L. C.,Cairncross, S.,Ferrer, S. R.,Fialho, A. M.,Leite, J. P.,Ribeiro, H. C., Jr.,Barreto, M. L. Factors associated with rotavirus diarrhoea in children living in a socially diverse urban centre in Brazil. Trans R Soc Trop Med Hyg. 2012;106(7):445-51.

2209 Strobl, W.,Widhalm, K. The natural history of serum lipids and lipoproteins during childhood. Prog Clin Biol Res. 1985;188:101-21.

2210 Study hints at link between breastfeeding and intelligence. AHRQ Research Activities. 2006(308):10-10 1p.

2211 Study Looks at Breastfeeding Impact on Leukemia. Neonatal Intensive Care. 2015;28(4):12-14 3p.

2212 Su, D.,Zhao, Y.,Binns, C.,Scott, J.,Oddy, W. Breast-feeding mothers can exercise: results of a cohort study. Public Health Nutr. 2007;10(10):1089-93.

2213 Subbarao, P.,Anand, S. S.,Becker, A. B.,Befus, A. D.,Brauer, M.,Brook, J. R.,Denburg, J. A.,Hayglass, K. T.,Kobor, M. S.,Kollmann, T. R., Kozyrskyj, A. L.,Lou, W. Y. W.,Mandhane, P. J.,Miller, G. E.,Moraes, T. J.,Pare, P. D., Scott, J. A., Takaro, T. K., Turvey, S. E., Duncan, J. M.,Lefebvre, D. L.,Sears, M. R. The Canadian Healthy Infant Longitudinal Development (CHILD) study: Examining developmental origins of allergy and asthma. Thorax. 2015;70(10):998-1000.

2214 Sudden infant death syndrome (SIDS). Canadian Foundation for the Study of Infant Deaths. Canadian Institute of Child Health. Canadian Paediatric Society. Can Fam Physician. 1999;45:702, 709-10.

2215 Suganuma, E. K.,Alexander, G. R.,Baruffi, G.,Gilden, S. R. Infant feeding practices in Hawaii. Hawaii Med J. 1988;47(3):112, 117-9.

2216 Sun, G.,Jia, G.,Peng, H.,Dickerman, B.,Compher, C.,Liu, J. Trends of childhood obesity in China and associated factors. Clin Nurs Res. 2015;24(2):156-71.

2217 Sun, J.,Huo, J.,Zhao, L.,Fu, P.,Wang, J.,Huang, J.,Wang, L.,Song, P.,Fang, Z.,Chang, S., Yin, S.,Zhang, J.,Ma, G. The nutritional status of young children and feeding practices two years after the Wenchuan Earthquake in the worst-affected areas in China. Asia Pac J Clin Nutr. 2013;22(1):100-8.
Study design, Health status

Independent variable Independent variable

Country

Group size

Group size

Study design,

Independent variable

Study design

Study design

Study design

Independent variable

Study design

Study design

Study design

Study design

Study design,

Independent variable 
2219 Suoglu, O. D.,Gokce, S.,Saglam, A. T.,Sokucu, S.,Saner, G. Association of Helicobacter pylori infection with gastroduodenal disease, epidemiologic factors and iron-deficiency anemia in Turkish children undergoing endoscopy, and impact on growth. Pediatr Int. 2007;49(6):85863.

2220 Surdu, S.,Montoya, L. D.,Tarbell, A.,Carpenter, D. O. Childhood asthma and indoor allergens in Native Americans in New York. Environ Health. 2006;5:22.

2221 Sussmann, J. E.,McIntosh, A. M.,Lawrie, S. M.,Johnstone, E. C. Obstetric complications and mild to moderate intellectual disability. Br J Psychiatry. 2009;194(3):224-8.

2222 Sutmoller, F.,Maia, P. R. Acute respiratory infections in children living in two low income communities of Rio de Janeiro, Brazil. Mem Inst Oswaldo Cruz. 1995;90(6):665-74.

2223 Syafruddin, M.,Djauhariah, A. M.,Dasril, D. A study comparing rooming-in with separate nursing. Paediatr Indones. 1988;28(5-6):116-23.

2224 Tada, A.,Ando, Y.,Hanada, N. Caries risk factors among three-year old children in Chiba, Japan. Asia Pac J Public Health. $1999 ; 11(2): 109-12$.

\section{Included for} systematic reviews not completed

\section{Country}

Included for

systematic reviews not completed

2225 Tainio, V. M. Lymphocyte subsets in infants: relationships to feeding, atopy, atopic heredity and infections. Int Arch Allergy Appl Immunol. 1985;78(3):305-10.

2226 Tainio, V. M.,Savilahti, E.,Salmenpera, L.,Arjomaa, P.,Siimes, M. A.,Perheentupa, J. Risk factors for infantile recurrent otitis media: atopy but not type of feeding. Pediatr Res. 1988;23(5):509-12.

Dependent variable

Included for

systematic reviews not completed

2227 Taitz, L. S.,Lukmanji, Z. Alterations in feeding patterns and rates of weight gain in South Yorkshire infants, 1971-1977. Hum Biol.

Study design 1981;53(3):313-20.

2228 Takala, A. K.,Eskola, J.,Palmgren, J.,Ronnberg, P. R.,Kela, E.,Rekola, P.,Makela, P. H. Risk factors of invasive Haemophilus influenzae type b disease among children in Finland. J Pediatr. 1989;115(5 Pt 1):694-701.

2229 Takemura, Y.,Sakurai, Y.,Honjo, S.,Kusakari, A.,Hara, T.,Gibo, M.,Tokimatsu, A.,Kugai, N. Relation between breastfeeding and the prevalence of asthma : the Tokorozawa Childhood Asthma and Pollinosis Study. Am J Epidemiol. 2001;154(2):115-9.

2230 Taki, M.,Mizuno, K.,Murase, M.,Nishida, Y.,Itabashi, K.,Mukai, Y. Maturational changes in the feeding behaviour of infants - a comparison between breast-feeding and bottle-feeding. Acta Paediatr. 2010;99(1):61-7.

2231 Talayero, J. M. P.,Lizán-García, M.,Puime Á, O.,Muncharaz, M. J. B.,Soto, B. B.,Sánchez-Palomares, M.,Serrano, L. S.,Rivera, L. L. Full breastfeeding and hospitalization as a result of infections in the first year of life. Pediatrics. 2006;118(1):e92-e99.

Dependent variable

Study design

Group size

Included for systematic reviews not completed 
2232 Tanaka, H.,Ishii, H.,Yamada, T.,Akazawa, K.,Nagata, S.,Yamashiro, Y. Growth of Japanese breastfed infants compared to national references and World Health Organization growth standards. Acta Paediatr. 2013;102(7):739-43.

2233 Tanaka, K.,Miyake, Y.,Sasaki, S. Association between breastfeeding and allergic disorders in Japanese children. Int J Tuberc Lung Dis. 2010;14(4):513-8.

2234 Tanaka, K.,Miyake, Y.,Sasaki, S.,Hirota, Y. Infant feeding practices and risk of dental caries in Japan: the Osaka Maternal And Child Health Study. Pediatr Dent. 2013;35(3):267-71.

2235 Tanaka, T.,Kato, N. Evaluation of child care practice factors that affect the occurrence of sudden infant death syndrome: Interview conducted by public health nurses. Environmental Health and Preventive Medicine. 2001;6(2):117-120.

Included for

systematic reviews not completed

Included for systematic reviews not completed

Country

2236 Taneja, S.,Bhandari, N.,Bahl, R.,Bhan, M. K. Impact of zinc supplementation on mental and psychomotor scores of children aged 12 to 18 months: a randomized, double-blind trial. J Pediatr. 2005;146(4):506-11.

2237 Tantracheewathorn, S. Growth of breast-fed and formula-fed infants compared with national growth references of Thai children. J Med Assoc Thai. 2005;88(2):168-75.

2238 Tantracheewathorn, S.,Lohajaroensub, S. Incidence and risk factors of iron deficiency anemia in term infants. J Med Assoc Thai. 2005;88(1):4551.

2239 Tanzer, F.,Gumuser, C. A study of the growth of 200 newborn babies for a period of 6 months according to the type of nutrition. Ann Trop Paediatr. 1989;9(1):54-8.

2240 Targino, A. G.,Rosenblatt, A.,Oliveira, A. F.,Chaves, A. M.,Santos, V. E. The relationship of enamel defects and caries: a cohort study. Oral Dis. 2011;17(4):420-6.

2241 Tariq, S.,Memon, I. A. Acute otitis media in children. Journal of the College of Physicians and Surgeons Pakistan. 1999;9(12):507-510.

2242 Tarrant, M.,Fong, D. Y.,Heys, M.,Lee, I. L.,Sham, A.,Hui Choi, E. W. Professional breastfeeding support to increase the exclusivity and duration of breastfeeding: a randomised controlled trial. Hong Kong Med J. 2014;20 Suppl 7:34-5.

2243 Tarrant, M.,Kwok, M. K.,Lam, T. H.,Leung, G. M.,Schooling, C. M. Breast-feeding and childhood hospitalizations for infections. Epidemiology. 2010;21(6):847-54

2244 Tarrant, M.,Schooling, C. M.,Leung, S. L.,Mak, K. H.,Ho, L. M.,Leung, G. M. Impact of breastfeeding on infectious disease hospitalisation: the children of 1997 cohort. Hong Kong Med J. 2014;20 Suppl 4:5-6.

2245 Tarrant, R. C.,Sheridan-Pereira, M.,Younger, K. M.,Kearney, J. M. The positive role of breastfeeding on infant health during the first 6 weeks: findings from a prospective observational study based on maternal reports. Ir Med J. 2012;105(3):75-8.
Included for

systematic reviews not completed

Included for systematic reviews not completed

Group size

Independent variable

Country

Study design, Dependent variable

Included for completed

Study design

Study design systematic reviews not 
2246 Taveras, E. M.,Gillman, M. W.,Kleinman, K. P.,Rich-Edwards, J. W.,Rifas-Shiman, S. L. Reducing racial/ethnic disparities in childhood obesity: the role of early life risk factors. JAMA Pediatr. 2013;167(8):731-8.

2247 Taveras, E. M.,Gillman, M. W.,Kleinman, K.,Rich-Edwards, J. W.,Rifas-Shiman, S. L. Racial/ethnic differences in early-life risk factors for childhood obesity. Pediatrics. 2010;125(4):686-95.

2248 Taveras, E. M.,Rifas-Shiman, S. L.,Scanlon, K. S.,Grummer-Strawn, L. M.,Sherry, B.,Gillman, M. W. To what extent is the protective effect of breastfeeding on future overweight explained by decreased maternal feeding restriction?. Pediatrics. 2006;118(6):2341-8.

Included for systematic reviews not completed

Included for systematic reviews not completed

Study design

2249 Tawia S. Childhood obesity and being breastfed. Breastfeed Rev. 2013;21:42-8.

Study design

2250 Taylor, B. Infant feeding and allergy: fact and fiction. Midwife Health Visit Community Nurse. 1984;20(10):354-60.

Study design

2251 Taylor, B.,Wadsworth, J. Breast feeding and child development at five years. Dev Med Child Neurol. 1984;26(1):73-80.

Independent variable

2252 Taylor, B.,Wadsworth, J.,Golding, J.,Butler, N. Breast feeding, eczema, asthma, and hayfever. J Epidemiol Community Health. 1983;37(2):95-9.

2253 Taylor, B.,Wadsworth, J.,Golding, J.,Butler, N. Breast-feeding, bronchitis, and admissions for lower-respiratory illness and gastroenteritis during the first five years. Lancet. 1982;1(8283):1227-9.

2254 Taylor, R. Providing additional guidance and support to parents about sleep, diet and physical activity from birth to 2 years of age: The Prevention of Overweight in Infancy study. Obesity research \& clinical practice. 2014;8:102-3.

2255 Taylor-Robinson, D. C.,Williams, H.,Pearce, A.,Law, C.,Hope, S. Do early life exposures explain why more advantaged children get eczema? Findings from the UK Millennium Cohort Study. Br J Dermatol. 2015.

2256 Tee, J. H. Some characteristics of 5-year-old children with a dmf of six or more in Gloucestershire, England. Community Dent Health. $1987 ; 4(2): 121-8$

2257 Teele, D. W.,Klein, J. O.,Rosner, B. Epidemiology of otitis media during the first seven years of life in children in greater Boston: a prospective cohort study. J Infect Dis. 1989;160(1):83-94.

2258 Teixeira Mde, L.,Lira, P. I.,Coutinho, S. B.,Eickmann, S. H.,Lima, M. C. Influence of breastfeeding type and maternal anemia on hemoglobin concentration in 6-month-old infants. J Pediatr (Rio J). 2010;86(1):65-72.

2259 Teixeira, Ana Karine Macedo,Menezes, LÃ@a Maria Bezerra de,Dias, Aldo Angelim,Alencar, Carlos Henrique Morais de,Almeida, Maria Eneide LeitÃ $£ o$ de. Analysis of protection or risk factors for dental fluorosis in 6 to 8 year-old children in Fortaleza, Brazil. Revista Panamericana de Salud Publica. 2010;28(6):421-428 8p.

2260 Teka, T.,Faruque, A. S.,Fuchs, G. J. Risk factors for deaths in under-age-five children attending a diarrhoea treatment centre. Acta Paediatr. 1996;85(9):1070-5
Independent variable

\section{Peer review}

Study design

Study design

Included for

systematic reviews not completed

Study design

Language

Country 
2261 Telahun, M.,Abdulkadir, J.,Kebede, E. The relation of early nutrition, infections and socio-economic factors to the development of childhood diabetes. Ethiop Med J. 1994;32(4):239-44.

2262 Temboury, M. C.,Otero, A.,Polanco, I.,Arribas, E. Influence of breast-feeding on the infant's intellectual development. J Pediatr Gastroentero Nutr. 1994;18(1):32-6.

2263 Tenebaum, D.,Gambert, P.,Meunier, S.,d'Athis, P.,Nivelon, J. L.,Lallemand, C. Serum lipoproteins in venous blood serum from birth to the end of Group size the first week: feeding influences. Biol Neonate. 1988;53(3):126-31.

2264 Thacher, T. D.,Fischer, P. R.,Tebben, P. J.,Singh, R. J.,Cha, S. S.,Maxson, J. A.,Yawn, B. P. Increasing incidence of nutritional rickets: a

Group size population-based study in Olmsted County, Minnesota. Mayo Clin Proc. 2013;88(2):176-83. in infants. Int J Paediatr Dent. 2012;22(3):197-202.

2266 Thapa, S.,Short, R. V.,Potts, M. Breast feeding, birth spacing and their effects on child survival. Nature. 1988;335(6192):679-82.

Country

Study design

2267 Thaver, I. H. "Risk approach" for reducing malnutrition in children from a privileged community. J Pak Med Assoc. 1990;40(3):59-61.

Country

2268 The Baby-Friendly Hospital Initiative. Birth Gaz. 1998;14:30.

Study design

2269 Thiering, E.,Bruske, I.,Kratzsch, J.,Thiery, J.,Sausenthaler, S.,Meisinger, C.,Koletzko, S.,Bauer, C. P.,Schaaf, B.,von Berg, A.,Berdel, Independent variable D.,Lehmann, I.,Herbarth, O.,Kramer, U.,Wichmann, H. E.,Heinrich, J. Prenatal and postnatal tobacco smoke exposure and development of insulin resistance in 10 year old children. Int J Hyg Environ Health. 2011;214(5):361-8.

2270 Thies, P. A.,Jeris, L. S. Infant feeding practices and dental health. Part 2: breastfeeding and dental caries. Bull Mich Dent Hyg Assoc. 1981;11(1):6-7, 20.

2271 Thitasomakul, S.,Piwat, S., Thearmontree, A.,Chankanka, O.,Pithpornchaiyakul, W.,Madyusoh, S. Risks for early childhood caries analyzed by negative binomial models. J Dent Res. 2009;88(2):137-41.

2272 Thomas, G. P.,Soni, N. N. Clinical manifestations and management of nursing bottle syndrome. J Md State Dent Assoc. 1987;30(2):62-4.

Study design

2273 Thomaz, E. B.,Cangussu, M. C.,Assis, A. M. Maternal breastfeeding, parafunctional oral habits and malocclusion in adolescents: a multivariate analysis. Int J Pediatr Otorhinolaryngol. 2012;76(4):500-6.

2274 Thompson, A. L.,Adair, L. S.,Bentley, M. E. Pressuring and restrictive feeding styles influence infant feeding and size among a low-income African-American sample. Obesity (Silver Spring). 2013;21(3):562-71.

Study design

Included for

systematic reviews not completed

2275 Thompson, A. L.,Lampl, M. Prenatal and postnatal energetic conditions and sex steroids levels across the first year of life. Am J Hum Biol. 2013;25(5):643-54.

2276 Thompson, M. Think zinc. Neonatal Netw. 1987;6(1):44-5.

Dependent variable

Study design 
2277 Thompson, N. P.,Montgomery, S. M.,Wadsworth, M. E.,Pounder, R. E.,Wakefield, A. J. Early determinants of inflammatory bowel disease: use of two national longitudinal birth cohorts. Eur J Gastroenterol Hepatol. 2000;12(1):25-30.

2278 Thomsen, S. F.,Ulrik, C. S.,Porsbjerg, C.,Backer, V. Early life exposures and risk of atopy among Danish children. Allergy Asthma Proc. 2006;27(2):110-4

2279 Thomson, J. L.,Tussing-Humphreys, L. M.,Goodman, M. H. Delta Healthy Sprouts: a randomized comparative effectiveness trial to promote maternal weight control and reduce childhood obesity in the Mississippi Delta. Contemp Clin Trials. 2014;38(1):82-91.

Dependent variable

Study design,

Dependent variable

2280 Thomson, K.,Morley, R.,Grover, S. R.,Zacharin, M. R. Postnatal evaluation of vitamin D and bone health in women who were vitamin D-deficient in pregnancy, and in their infants. Med J Aust. 2004;181(9):486-8.

2281 Thomson, M. Otitis media. How are First Nations children affected?. Can Fam Physician. 1994;40:1943-50.

Group size

Study design,

Independent variable

2282 Thorisdottir, A. V.,Ramel, A.,Palsson, G. I.,Tomassson, H.,Thorsdottir, I. Iron status of one-year-olds and association with breast milk, cow's milk or formula in late infancy. Eur J Nutr. 2013;52(6):1661-8.

Included for

systematic reviews not completed

2283 Thorpe, K.,Rutter, M.,Greenwood, R. Twins as a natural experiment to study the causes of mild language delay: II: Family interaction risk factors. J Child Psychol Psychiatry. 2003;44(3):342-55.

Included for systematic reviews not completed

2284 Thorsdottir, I.,Gunnarsdottir, I.,Kvaran, M. A.,Gretarsson, S. J. Maternal body mass index, duration of exclusive breastfeeding and children's Independent variable development status at the age of 6 years. European Journal of Clinical Nutrition. 2005;59(3):426-431.

2285 Thorsdottir, I.,Gunnarsdottir, I.,Kvaran, M. A.,Gretarsson, S. J. Maternal body mass index, duration of exclusive breastfeeding and children's developmental status at the age of 6 years. Eur J Clin Nutr. 2005;59(3):426-31.

2286 Thorsdottir, I.,Gunnarsdottir, I.,Palsson, G. I.. Birth weight, growth and feeding in infancy: relation to serum lipid concentration in 12-month-old infants. Eur J Clin Nutr. 2003;57(11):1479-85.

2287 Thorsdottir, I.,Gunnarsson, B. S. Dietary quality and adequacy of micronutrient intakes in children. Proc Nutr Soc. 2006;65(4):366-75.

Study design

2288 Thorsdottir, I.,Gunnarsson, B. S.,Atladottir, H.,Michaelsen, K. F.,Palsson, G. Iron status at 12 months of age -- effects of body size, growth and diet in a population with high birth weight. Eur J Clin Nutr. 2003;57(4):505-13.

Independent variable

Dependent variable

Included for systematic reviews not completed

2289 Thurtle, V. Infant feeding. Nurs Mirror. 1985;160(19):44-5.

Study design,

Dependent variable

2290 Timby, N.,Domellof, E.,Hernell, O.,Lonnerdal, B.,Domellof, M. Neurodevelopment, nutrition, and growth until 12 mo of age in infants fed a lowIndependent variable energy, low-protein formula supplemented with bovine milk fat globule membranes: a randomized controlled trial. Am J Clin Nutr. 2014;99(4):860-8 
2291 Timby, N.,Hernell, O.,Lonnerdal, B.,Domellof, M. Parental feeding control in relation to feeding mode and growth pattern during early infancy. Acta Paediatr. 2014;103(10):1072-7.

2292 Timby, N.,Hernell, O.,Vaarala, O.,Melin, M.,Lonnerdal, B.,Domellof, M. Infections in infants fed formula supplemented with bovine milk fat globule membranes. J Pediatr Gastroenterol Nutr. 2015;60(3):384-9.

2293 Timby, N.,Lonnerdal, B.,Hernell, O.,Domellof, M. Cardiovascular risk markers until 12 mo of age in infants fed a formula supplemented with bovine milk fat globule membranes. Pediatr Res. 2014;76(4):394-400.

2294 Timmermans, F. J.,Gerson, S. Chronic granulomatous otitis media in bottle-fed Inuit children. Can Med Assoc J. 1980;122(5):545-7.

Independent variable

2295 Timmermans, M. J.,Dagnelie, P. C., Theunisz, E. H.,Ewalds, D.,Thijs, C.,Mommers, M.,Arts, I. C. Dietary nucleotide and nucleoside exposure in

Independent variable infancy and atopic dermatitis, recurrent wheeze, and allergic sensitization. J Pediatr Gastroenterol Nutr. 2015;60(5):691-3.

2296 Tiwari, S. Age of Introduction of Complementary Feeding and Iron Deficiency Anemia in Breastfed Infants, Child Health Viewpoint. Indian Pediatr. 2015;52(11):977-8.

2297 Todd, R.,Gelbier, S. Dental caries prevalence in Vietnamese children and teenagers in three London boroughs. Br Dent J. 1990;168(1):24-6.

Study design

2298 Tom, W. L. Atopic dermatitis: Recent findings and insights. Pediatric Annals. 2012;41(1):1-5.

Study design

2299 Tomblin, J. B.,Smith, E.,Zhang, X. Epidemiology of specific language impairment: prenatal and perinatal risk factors. J Commun Disord 1997;30(4):325-43; quiz 343-4

Included for

systematic reviews not completed

2300 Toms, G. L.,Scott, R. Respiratory syncytial virus and the infant immune response. Arch Dis Child. 1987;62(6):544-6.

Study design Independent variable

2301 Toro Monjaraz, E. M.,Ramirez Mayans, J. A.,Cervantes Bustamante, R.,Gomez Morales, E.,Molina Rosales, A.,Montijo Barrios, E.,Zarate Mondragon, F.,Cadena Leon, J.,Cazares Mendez, M.,Lopez-Ugalde, M. Perinatal factors associated with the development of cow's milk protein

Language, Study allergy. Rev Gastroenterol Mex. 2015;80(1):27-31.

2302 Toro, K.,Sotonyi, P. Distribution of prenatal and postnatal risk factors for sudden infant death in Budapest. Scand J Prim Health Care. 2001;19(3):178-80.

2303 Torowicz, Deborah L.,Spatz, Diane L.,Seelhorst, Amanda. Human Milk and Breastfeeding in the Cardiac Center: A Prospective, Descriptive Study. Journal of Pediatric Healthcare. 2013;27(5):325-325 1p.

2304 Torsvik, I. K.,Markestad, T.,Ueland, P. M.,Nilsen, R. M.,Midttun, O.,Bjorke Monsen, A. L. Evaluating iron status and the risk of anemia in young infants using erythrocyte parameters. Pediatr Res. 2013;73(2):214-20.

2305 Toschke, A. M.,Beyerlein, A.,von Kries, R. Children at high risk for overweight: a classification and regression trees analysis approach. Obes Res. 2005;13(7):1270-4

design

Independent variable

Health status

Group size

Study design 
2306 Toschke, A. M.,Martin, R. M.,von Kries, R.,Wells, J.,Smith, G. D.,Ness, A. R. Infant feeding method and obesity: body mass index and dualenergy X-ray absorptiometry measurements at 9-10 y of age from the Avon Longitudinal Study of Parents and Children (ALSPAC). Am J Clin Nutr. 2007;85(6):1578-85.

2307 Toselli, S.,Zaccagni, L.,Celenza, F.,Albertini, A.,Gualdi-Russo, E. Risk factors of overweight and obesity among preschool children with different ethnic background. Endocrine. 2015;49(3):717-25.

2308 Tozzi, A. E.,Bisiacchi, P.,Tarantino, V.,Chiarotti, F.,D'Elia, L.,De Mei, B.,Romano, M.,Gesualdo, F.,Salmaso, S. Effect of duration of breastfeeding on neuropsychological development at 10 to 12 years of age in a cohort of healthy children. Dev Med Child Neurol. 2012;54(9):843-8.

2309 Trabulsi, J.,Capeding, R.,Lebumfacil, J.,Ramanujam, K.,Feng, P.,McSweeney, S.,Harris, B.,DeRusso, P. Effect of an alpha-lactalbumin-enriched infant formula with lower protein on growth. Eur J Clin Nutr. 2011;65(2):167-74.

Included for systematic reviews not completed

Study design

Independent variable

Included for

systematic reviews not completed

Independent variable Country iron deficiency disorder and common mental disorders. PLoS One. 2013;8(9):e74876.

2311 Trapp, P. G.,Mielke, J. H.,Jorde, L. B.,Eriksson, A. W. Infant mortality patterns in Aland, Finland. Hum Biol. 1983;55(1):131-49.

Study design

Independent variable

2312 Trevino-Garza, C.,Mancillas-Adame, L.,Villarreal-Perez, J. Z.,De la, O. Cavazos M. E.,Estrada-Zuniga, C. M.,Bosques-Padilla, F. J.,Argente, J. Association between umbilical cord leptin and weight gain according to feeding type in the early postnatal period, a brief report. Rev Invest Clin. 2012;64(6 Pt 2):615-9.

2313 Truswell, A. S. ABC of nutrition. Infant feeding. Br Med J (Clin Res Ed). 1985;291(6491):333-7.

Included for

systematic reviews not completed

Study design

Study design

2314 Tsai, A. I.,Johnsen, D. C.,Lin, Y. H.,Hsu, K. H. A study of risk factors associated with nursing caries in Taiwanese children aged $24-48$ months. Int J Paediatr Dent. 2001;11(2):147-9.

2315 Tsai, S. F.,Chen, S. J.,Yen, H. J.,Hung, G. Y.,Tsao, P. C.,Jeng, M. J.,Lee, Y. S.,Soong, W. J.,Tang, R. B. Iron deficiency anemia in predominantly breastfed young children. Pediatr Neonatol. 2014;55(6):466-9.

2316 Tsao, P. C.,Chang, F. Y.,Chen, S. J.,Soong, W. J.,Jeng, M. J.,Lee, Y. S.,Yen, H. J.,Yang, C. F., Tang, R. B. Sudden and unexpected and near death during the early neonatal period: a multicenter study. J Chin Med Assoc. 2012;75(2):65-9.

2317 Tse, S. M.,Coull, B. A.,Sordillo, J. E.,Datta, S.,Gold, D. R. Gender- and age-specific risk factors for wheeze from birth through adolescence. Pediatric Pulmonology. 2015;50(10):955-962.

2318 Tseng, E.,Potter, S. M.,Picciano, M. F. Dietary protein source and plasma lipid profiles of infants. Pediatrics. 1990;85(4):548-52.

2319 Tsubouchi, J.,Higashi, T.,Shimono, T.,Domoto, P. K.,Weinstein, P. A study of baby bottle tooth decay and risk factors for 18-month old infants in rural Japan. ASDC J Dent Child. 1994;61(4):293-8.

2320 Tsubouchi, J.,Tsubouchi, M.,Maynard, R. J.,Domoto, P. K.,Weinstein, P. A study of dental caries and risk factors among Native American infants. ASDC J Dent Child. 1995;62(4):283-7.
Group size

Study design, Health status

Study design

Dependent variable

Study design

Study design 

relation to growth and body composition in adolescence. Obes Res. 1999;7(5):431-7.

2323 Tuncbilek, E.,Uner, S.,Ulusoy, M. Breastfeeding in Turkey: the demographic and socio-economic aspects and relationship with infant/child mortality. Turk J Pediatr. 1983;25(1):3-23.

2324 Turck, D.,Grillon, C.,Lachambre, E.,Robiliard, P.,Beck, L.,Maurin, J. L.,Kempf, C.,Bernet, J. P.,Marx, J.,Lebrun, F., Van Egroo, L. D. Adequacy and safety of an infant formula with a protein/energy ratio of $1.8 \mathrm{~g} / 100 \mathrm{kcal}$ and enhanced protein efficiency for term infants during the first 4 months of life. J Pediatr Gastroenterol Nutr. 2006;43(3):364-71.

2326 Turner, S.,Zhang, G.,Young, S.,Cox, M.,Goldblatt, J.,Landau, L.,Le Souef, P. Associations between postnatal weight gain, change in postnatal pulmonary function, formula feeding and early asthma. Thorax. 2008;63(3):234-9.

2327 Tuthill, D. P.,Cosgrove, M.,Dunstan, F.,Stuart, M. L.,Wells, J. C.,Davies, D. P. Randomized double-blind controlled trial on the effects on iron status in the first year between a no added iron and standard infant formula received for three months. Acta Paediatr. 2002;91(2):119-24.

2328 Tyler, M.,Hellings, P. Feeding method and rehospitalization in newborns less than 1 month of age. J Obstet Gynecol Neonatal Nurs. 2005;34(1):70-9.

2329 Tyson, J.,Burchfield, J.,Sentance, F.,Mize, C.,Uauy, R.,Eastburn, J. Adaptation of feeding to a low fat yield in breast milk. Pediatrics. 1992;89(2):215-20.

2330 Uauy, R.,Mize, C. E.,Castillo-Duran, C. Fat intake during childhood: metabolic responses and effects on growth. Am J Clin Nutr. 2000;72(5 Suppl):1354S-1360S.

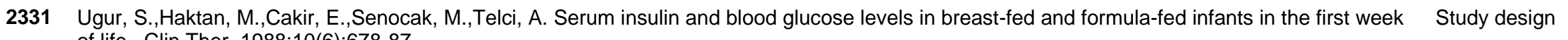
of life. Clin Ther. 1988;10(6):678-87.

2332 Uhl, O.,Hellmuth, C.,Demmelmair, H.,Zhou, S. J.,Makrides, M.,Prosser, C.,Lowry, D., Gibson, R. A.,Koletzko, B. Dietary Effects on Plasma Glycerophospholipids. J Pediatr Gastroenterol Nutr. 2015;61(3):367-72.

Study design,

Dependent variable

Independent variable

Independent variable

Included for

systematic reviews not completed

Health status

Independent variable

Study design

Dependent variable

Study design

2333 Uijterschout, L.,Vloemans, J.,Vos, R.,Teunisse, P. P.,Hudig, C.,Bubbers, S.,Verbruggen, S.,Veldhorst, M.,De Leeuw, T.,Van Goudoever, J. B.,Brus, F. Prevalence and risk factors of iron deficiency in healthy young children in the southwestern netherlands. Journal of Pediatric Gastroenterology and Nutrition. 2014;58(2):193-198.

2334 Umer, A.,Hamilton, C.,Britton, C. M.,Mullett, M. D.,John, C.,Neal, W.,Lilly, C. L. Association between Breastfeeding and Childhood Obesity: Analysis of a Linked Longitudinal Study of Rural Appalachian Fifth-Grade Children. Child Obes. 2015;11(4):449-55.

2335 Unay, B.,Sarici, S. U.,Ulas, U. H.,Akin, R.,Alpay, F.,Gokcay, E. Nutritional effects on auditory brainstem maturation in healthy term infants. Arch Group size Dis Child Fetal Neonatal Ed. 2004;89(2):F177-9. 

2336 UP11 The Feeding Young Children Study: Preliminary Results from a WIC-based Bottle Weaning Intervention. Journal of Nutrition Education \&
Behavior. 2012;44(4S1):S83-S83 1p.

2337 Vaarala, O.,Ilonen, J.,Ruohtula, T.,Pesola, J.,Virtanen, S. M.,Harkonen, T.,Koski, M.,Kallioinen, H.,Tossavainen, O.,Poussa, T.,Jarvenpaa, A. L.,Komulainen, J.,Lounamaa, R.,Akerblom, H. K.,Knip, M. Removal of bovine insulin from cow's milk formula and early initiation of beta-cell autoimmunity in the FINDIA pilot study. Archives of pediatrics \& adolescent medicine. 2012;166(7):608-14.

2338 Vaarala, O.,Knip, M.,Paronen, J.,Hamalainen, A. M.,Muona, P.,Vaatainen, M.,llonen, J.,Simell, O.,Akerblom, H. K. Cow's milk formula feeding induces primary immunization to insulin in infants at genetic risk for type 1 diabetes. Diabetes. 1999;48(7):1389-94.

2339 Vafa, M.,Heshmati, J.,Sadeghi, H.,Shidfar, F.,Namazi, N.,Baradaran, H.,Heydarpour, B.,Jalili, Z.. Is exclusive breastfeeding and its duration related to cardio respiratory fitness in childhood?. J Matern Fetal Neonatal Med. 2015;\#volume\#(\#issue\#):1-6.

2340 Vaidergorn, B. Oral habits and atypical deglutition in certain Sao Paulo children. Int J Orofacial Myology. 1991;17(3):11-5.

tudy design,

Independent variable

2341 Valaitis, R. K.,Ciliska, D. K.,Sheeshka, J. D.,Sword, W. A. Surveying infant feeding practices. Can Nurse. 1996;92(4):21.

Study design

2342 Valman, H. B. The first year of life: feeding and feeding problems. Br Med J. 1980;280(6212):457-60.

Study design

2343 Valvi, D.,Mendez, M. A.,Garcia-Esteban, R.,Ballester, F.,Ibarluzea, J.,Goni, F.,Grimalt, J. O.,Llop, S.,Marina, L. S., Vizcaino, E., Sunyer, J.,Vrijheid, M. Prenatal exposure to persistent organic pollutants and rapid weight gain and overweight in infancy. Obesity (Silver Spring). 2014;22(2):488-96.

2344 Van Asperen, P. P.,Kemp, A. S.,Mellis, C. M. Relationship of diet in the development of atopy in infancy. Clin Allergy. 1984;14(6):525-32.

2345 Van Biervliet, J. P.,Rosseneu, M.,Caster, H. Influence of dietary factors on the plasma lipoprotein composition and content in neonates. Eur J Pediatr. 1986;144(5):489-93. 2346 Van Biervliet, J. P.,Vinaimont, N.,Caster, H.,Vercaemst, R.,Rosseneu, M. Lipoprotein patterns in newborns. Influence of nutritional factors. Acta
Cardiol Suppl. 1981;27:69-81.

2347 van Biervliet, J. P.,Vinaimont, N.,Caster, H.,Vercaemst, R.,Rosseneu, M. Plasma apoprotein and lipid patterns in newborns: influence of nutritional factors. Acta Paediatr Scand. 1981;70(6):851-6.

2348 Van Biervliet, J. P.,Vinaimont, N.,Vercaemst, R.,Rosseneu, M. Serum cholesterol, cholesteryl ester, and high-density lipoprotein development in Group size newborn infants: response to formulas supplemented with cholesterol and gamma-linolenic acid. J Pediatr. 1992;120(4 Pt 2):S101-8.

2349 Van Biervliet, S.,Van Biervliet, J. P.,Bernard, D.,Vercaemst, R.,Blaton, V. Serum zinc in healthy Belgian children. Biological Trace Element Research. 2003;94(1):33-40. 175-9.

2351 van den Berg, G.,van Eijsden, M.,Galindo-Garre, F.,Vrijkotte, T. G.,Gemke, R. J. Explaining socioeconomic inequalities in childhood blood pressure and prehypertension: the ABCD study. Hypertension. 2013;61(1):35-41.

Study design

Independent variable 
2352 Van Den Berg, G.,Van Eijsden, M.,Galindo-Garre, F.,Vrijkotte, T.,Gemke, R. Low maternal education is associated with increased growth velocity in the first year of life and in early childhood: the ABCD study. Eur J Pediatr. 2013;172(11):1451-7.

Included for systematic reviews not completed

Independent variable

2353 van den Bogaard, C.,van den Hoogen, H. J.,Huygen, F. J.,van Weel, C. Is the breast best for children with a family history of atopy? The relation between way of feeding and early childhood morbidity. Fam Med. 1993;25(7):471-5.

2354 van den Bogaard, C.,van den Hoogen, H. J.,Huygen, F. J.,van Weel, C. The relationship between breast-feeding and early childhood morbidity in a general population. Fam Med. 1991;23(7):510-5.

2355 Van der Elst, C. W.,Dempster, W. S.,Woods, D. L.,Heese, H. D. Serum zinc and copper in thin mothers, their breast milk and their infants. J Trop Pediatr. 1986;32(3):111-4.

2356 van der Willik, E. M.,Vrijkotte, T. G.,Altenburg, T. M.,Gademan, M. G.,Kist-van Holthe, J. Exclusively breastfed overweight infants are at the same risk of childhood overweight as formula fed overweight infants. Arch Dis Child. 2015;100(10):932-7.

2357 van Dijk, C. E.,Innis, S. M. Growth-curve standards and the assessment of early excess weight gain in infancy. Pediatrics. 2009;123(1):102-8.

Independent variable

2358 van Elten, T. M.,van Rossem, L.,Wijga, A. H.,Brunekreef, B.,de Jongste, J. C.,Koppelman, G. H.,Smit, H. A. Breast milk fatty acid composition has a long-term effect on the risk of asthma, eczema, and sensitization. Allergy. 2015;70(11):1468-76.

2359 Van Howe, R. S.,Storms, M. R. Blood glucose determinations in large for gestational age infants. Am J Perinatol. 2008;25(5):283-9.

2360 van Merode, T.,Maas, T.,Twellaar, M.,Kester, A.,van Schayck, C. P. Gender-specific differences in the prevention of asthma-like symptoms in high-risk infants. Pediatr Allergy Immunol. 2007;18(3):196-200.

2361 van Odijk, J.,Hulthen, L.,Ahlstedt, S.,Borres, M. P. Introduction of food during the infant's first year: a study with emphasis on introduction of gluten and of egg, fish and peanut in allergy-risk families. Acta Paediatr. 2004;93(4):464-70.

2362 van Palenstein Helderman, W. H.,Soe, W.,van 't Hof, M. A. Risk factors of early childhood caries in a Southeast Asian population. J Dent Res. 2006;85(1):85-8.

2363 van Rossem, L.,Taveras, E. M.,Gillman, M. W.,Kleinman, K. P.,Rifas-Shiman, S. L.,Raat, H.,Oken, E. Is the association of breastfeeding with child obesity explained by infant weight change?. Int J Pediatr Obes. 2011;6(2-2):e415-22.

2364 van Rossem, L.,Wijga, A. H.,Brunekreef, B.,de Jongste, J. C.,Kerkhof, M.,Postma, D. S., Gehring, U.,Smit, H. A. Overweight in infancy: which pre- and perinatal factors determine overweight persistence or reduction? A birth cohort followed for 11 years. Ann Nutr Metab. 2014;65(23):211-9.

2365 van Stuijvenberg, M.,Eisses, A. M.,Gruber, C.,Mosca, F.,Arslanoglu, S.,Chirico, G.,Braegger, C. P.,Riedler, J.,Boehm, G.,Sauer, P. J. Do prebiotics reduce the number of fever episodes in healthy children in their first year of life: a randomised controlled trial. Br $\mathrm{J}$ Nutr. 2011;106(11):1740-8.
Study design,

Independent variable

Study design

ndependent variable Country

Independent variable

ndependent variable

Dependent variable

Study design,

Independent variable

Independent variable, Country

Included for systematic reviews not completed

Included for systematic reviews not completed

Independent variable 
2366 van Stuijvenberg, M.,Stam, J.,Gruber, C.,Mosca, F.,Arslanoglu, S.,Chirico, G.,Braegger, C. P.,Riedler, J.,Boehm, G.,Sauer, P. J. Similar Occurrence of Febrile Episodes Reported in Non-Atopic Children at Three to Five Years of Age after Prebiotics Supplemented Infant Formula. PLoS One. 2015;10(6):e0129927.

2367 van t Hof Msc, M. A. The influence of breastfeeding and complementary foods on growth until three years of age in the Euro-Growth Study. Pediatrics. 2000;106(5):1281a-1281.

2368 van Wouwe, J. P.,van den Hamer, C. J.,van Tricht, J. B. Serum zinc concentrations in exclusively breast-fed infants and in infants fed an adapted formula. Eur J Pediatr. 1986;144(6):598-600.

2369 Vandenplas, Y.,Deneyer, M.,Sacre, L.,Loeb, H. Preliminary data on a field study with a new hypo-allergic formula. European Journal of Pediatrics. 1988;148(3):274-277.

2370 Vandenplas, Y.,Sacre, L. Influences of neonatal serum IgE concentration, family history and diet on the incidence of cow's milk allergy. Eur J Pediatr. 1986;145(6):493-5.

2371 Vanderhoof, J. A.,Murray, N. D.,Antonson, D. L.,Kaufman, S. S. Familial occurrence of protracted diarrhea of infancy. J Pediatr. 1986;109(5):845-7.

2372 Vanella, L., de Gonzalez Lascano, A. M. CD4+, CD8+ cells, IgE and prick test in infants allergic to cow's milk. Allergol Immunopathol (Madr). 1988;16(5):327-31.

2373 Vanessa Nazareth, Isis,Maria Meneses dos Santos, InÃas,Paula Oliveira GonÃßalves, Ana,Sena Souza, Ester. RISK FOR CHILD DEVELOPMENT ACCORDING TO THE INTEGRATED ATTENTION STRATEGY TO THE PREVALENT ILLNESSES IN CHILDHOOD. JOURA of Nursing UFPE / Revista de Enfermagem UFPE. 2013;7(2):328-336 9p.

2374 Varga, G. A comparative study of the social-political determinants of infant and child mortality in Sweden and Hungary 1850-1945. Orvostort Kozl. 2008;54(1-4):5-29.

2375 Vasallo, M. I.,Martinez, R.,Ballesta, M. J.,Vives, I.,Sanchez-Solis, M.,Peso, P.,Martinez, C. Effect of an infant formula containing milk fat, Alphalactalbumin, Nucleotides and Icpufa on stool patterns in infants. Journal of pediatric gastroenterology and nutrition. 2011;52:E166.

2376 Vazquez, E. 14th annual retrovirus conference (CROI). Astounding choice in breastfeeding: infection or death. Posit Aware. 2007;18(3):29-30.

2377 Veereman-Wauters, G.,Staelens, S., Van de Broek, H.,Plaskie, K.,Wesling, F.,Roger, L. C.,McCartney, A. L.,Assam, P. Physiological and bifidogenic effects of prebiotic supplements in infant formulae. J Pediatr Gastroenterol Nutr. 2011;52(6):763-71.

2378 Vehapoglu, A.,Yazici, M.,Demir, A. D.,Turkmen, S.,Nursoy, M.,Ozkaya, E. Early infant feeding practice and childhood obesity: the relation of breast-feeding and timing of solid food introduction with childhood obesity. J Pediatr Endocrinol Metab. 2014;27(11-12):1181-7.

2379 Venkataraman, P. S.,Luhar, H.,Neylan, M. J. Bone mineral metabolism in full-term infants fed human milk, cow milk-based, and soy-based formulas. Am J Dis Child. 1992;146(11):1302-5.

2380 Vennemann, M. M.,Bajanowski, T.,Brinkmann, B.,Jorch, G.,Yucesan, K.,Sauerland, C.,Mitchell, E. A. Does breastfeeding reduce the risk of sudden infant death syndrome?. Pediatrics. 2009;123(3):e406-10. 
2381 Vennemann, M. M.,Findeisen, M.,Butterfass-Bahloul, T.,Jorch, G.,Brinkmann, B.,Kopcke, W.,Bajanowski, T.,Mitchell, E. A. Modifiable risk factors for SIDS in Germany: results of GeSID. Acta Paediatr. 2005;94(6):655-60.

Included for systematic reviews not completed

Included for systematic reviews not completed

Independent variable

Included for

systematic reviews not completed

Study design

Study design

Independent variable

Independent variable

Health status

Study design course in the 60s and mid-70s. Acta Paediatr Scand. 1981;70(3):289-95.

2388 Vernacchio, L.,Lesko, S. M.,Vezina, R. M.,Corwin, M. J.,Hunt, C. E.,Hoffman,
otitis media in infancy. Int J Pediatr Otorhinolaryngol. 2004;68(6):795-804.

2389 Verstraete, S. G.,Heyman, M. B.,Wojcicki, J. M. Breastfeeding offers protection against obesity in children of recently immigrated Latina women. J Community Health. 2014;39(3):480-6.

Included for systematic reviews not completed

Independent variable

2390 Vesel, L.,Bahl, R.,Martines, J.,Penny, M.,Bhandari, N.,Kirkwood, B. R. Use of new World Health Organization child growth standards to assess how infant malnutrition relates to breastfeeding and mortality. Bull World Health Organ. 2010;88(1):39-48.

2391 Vesikari, T.,Prymula, R.,Schuster, V.,Tejedor, J. C.,Cohen, R.,Bouckenooghe, A.,Damaso, S.,Han, H. H. Efficacy and immunogenicity of liveattenuated human rotavirus vaccine in breast-fed and formula-fed European infants. Pediatr Infect Dis J. 2012;31(5):509-13.

2392 Vestergaard, M.,Obel, C.,Henriksen, T. B.,Sorensen, H. T.,Skajaa, E.,Ostergaard, J. Duration of breastfeeding and developmental milestones during the latter half of infancy. Acta Paediatr. 1999;88(12):1327-32.

2393 Vestman, N. R.,Timby, N.,Holgerson, P. L.,Kressirer, C. A.,Claesson, R.,Domellof, M.,Ohman, C.,Tanner, A. C.,Hernell, O.,Johansson, I. Characterization and in vitro properties of oral lactobacilli in breastfed infants. BMC Microbiol. 2013;13:193.

2394 Vichyanond, P. IgE regulation and the control of allergic diseases. Asian Pac J Allergy Immunol. 1990;8(1):1-4.
Dependent variable

ncluded for

systematic reviews not completed

Study design

Study design 
2396 Victora, C. G.,Barros, F.,Lima, R. C.,Horta, B. L.,Wells, J. Anthropometry and body composition of 18 year old men according to duration of breast feeding: birth cohort study from Brazil. BMJ. 2003;327(7420):901.
Included for systematic reviews not completed

Independent variable

Study design

Included for

systematic reviews not completed

Included for

systematic reviews not completed

Study design

Independent variable

Independent variable

Study design

Included for

systematic reviews not

completed

Included for

systematic reviews not completed

Included for

systematic reviews not completed

2407 Victora, C. G.,Smith, P. G.,Vaughan, J. P.,Nobre, L. C.,Lombardi, C.,Teixeira, A. M.,Fuchs, S. M.,Moreira, L. B.,Gigante, L. P.,Barros, F. C. Evidence for protection by breast-feeding against infant deaths from infectious diseases in Brazil. Lancet. 1987;2(8554):319-22. 

1984;39(2):307-14

2409 Viggiano, D.,Fasano, D.,Monaco, G.,Strohmenger, L. Breast feeding, bottle feeding, and non-nutritive sucking; effects on occlusion in deciduous dentition. Arch Dis Child. 2004;89(12):1121-3.

2410 Vigi, V.,Chierici, R.,Osti, L.,Fagioli, F.,Rescazzi, R. Serum zinc concentration in exclusively breast-fed infants and in infants fed an adapted formula. Eur J Pediatr. 1984;142(4):245-7.

2411 Vignerova, J.,Shriver, L.,Paulova, M.,Brabec, M.,Schneidrova, D.,Ruzkova, R.,Prochazka, B.,Riedlovia, J. Growth of Czech breastfed infants in comparison with the World Health Organization standards. Cent Eur J Public Health. 2015;23(1):32-8.

2412 Villalpando, S. Feeding mode, infections, and anthropometric status in early childhood. Pediatrics. 2000;106(5):1282-3.

2413 Villalpando, S.,Lopez-Alarcon, M. Growth faltering is prevented by breast-feeding in underprivileged infants from Mexico City. J Nutr. 2000;130(3):546-52.

Included for

systematic reviews not completed

2414 Viner, R. M.,Hindmarsh, P. C.,Taylor, B.,Cole, T. J. Childhood body mass index (BMI), breastfeeding and risk of Type 1 diabetes: findings from a longitudinal national birth cohort. Diabet Med. 2008;25(9):1056-61.

2415 Violato, M.,Petrou, S.,Gray, R.,Redshaw, M. Family income and child cognitive and behavioural development in the United Kingdom: does money matter?. Health Econ. 2011;20(10):1201-25.

2416 Virtanen, S. M.,Kenward, M. G.,Erkkola, M.,Kautiainen, S.,Kronberg-Kippila, C.,Hakulinen, T.,Ahonen, S.,Uusitalo, L.,Niinisto, S.,Veijola, R.,Simell, O.,llonen, J.,Knip, M. Age at introduction of new foods and advanced beta cell autoimmunity in young children with HLA-conferred susceptibility to type 1 diabetes. Diabetologia. 2006;49(7):1512-21.

2417 Virtanen, S. M.,Rasanen, L.,Ylonen, K.,Aro, A.,Clayton, D.,Langholz, B.,Pitkaniemi, J.,Savilahti, E.,Lounamaa, R.,Tuomilehto, J.,et al.,. Early introduction of dairy products associated with increased risk of IDDM in Finnish children. The Childhood in Diabetes in Finland Study Group. Diabetes. 1993;42(12):1786-90.

2418 Vithayasai, N.,Jennuvat, S. Persistent diarrhea: 15 years experience at a tertiary care hospital. J Med Assoc Thai. 2014;97 Suppl 6:S95-100.

2419 Vitolo, M. R.,Bortolini, G. A.,Dal Bo Campagnolo, P.,Feldens, C. A. Effectiveness of a nutrition program in reducing symptoms of respiratory morbidity in children: a randomized field trial. Prev Med. 2008;47(4):384-8.

2420 Vitolo, M. R.,Bortolini, G. A.,Feldens, C. A.,Drachler Mde, L. [Impacts of the 10 Steps to Healthy Feeding in Infants: a randomized field trial]. Cadernos de saúde pública. 2005;21(5):1448-57.

2421 Vivatvakin, B.,Mahayosnond, A.,Theamboonlers, A.,Steenhout, P. G.,Conus, N. J. Effect of a whey-predominant starter formula containing LCPUFAs and oligosaccharides (FOS/GOS) on gastrointestinal comfort in infants. Asia Pac J Clin Nutr. 2010;19(4):473-80.

2422 Vobecky, J. S.,Vobecky, J.,Shapcott, D.,Demers, P. P. Nutrient intake patterns and nutritional status with regard to relative weight in early infancy. Am J Clin Nutr. 1983;38(5):730-8.

Health status

Study design,

Independent variable

Independent variable,

Dependent variable

Redundant data

Dependent variable

Language

Dependent variable

Included for

systematic reviews not completed 
2423 Vogazianos, E.,Vogazianos, P.,Fiala, J.,Janecek, D.,Slapak, I. The effect of breastfeeding and its duration on acute otitis media in children in Brno, Czech Republic. Cent Eur J Public Health. 2007;15(4):143-6.

2424 Volz, V. R.,Book, L. S.,Churella, H. R. Growth and plasma amino acid concentrations in term infants fed either whey-predominant formula or human milk. J Pediatr. 1983;102(1):27-31.

2425 von Berg, A.,Koletzko, S.,Filipiak-Pittroff, B.,Laubereau, B.,Grubl, A.,Wichmann, H. E.,Bauer, C. P.,Reinhardt, D.,Berdel, D. Certain hydrolyzed formulas reduce the incidence of atopic dermatitis but not that of asthma: three-year results of the German Infant Nutritional Intervention Study. J Allergy Clin Immunol. 2007;119(3):718-25.

2426 von Berg, A.,Koletzko, S.,Grubl, A.,Filipiak-Pittroff, B.,Wichmann, H. E.,Bauer, C. P.,Reinhardt, D.,Berdel, D. The effect of hydrolyzed cow's milk formula for allergy prevention in the first year of life: the German Infant Nutritional Intervention Study, a randomized double-blind trial. J Allergy Clin Immunol. 2003;111(3):533-40

2427 von Linstow, M. L.,Hogh, M.,Nordbo, S. A.,Eugen-Olsen, J.,Koch, A.,Hogh, B. A community study of clinical traits and risk factors for human metapneumovirus and respiratory syncytial virus infection during the first year of life. Eur J Pediatr. 2008;167(10):1125-33.

2428 von Mutius, E.,Hartert, T. Update in asthma 2012. Am J Respir Crit Care Med. 2013;188(2):150-6.

Study design

2429 von Stumm, S.,Plomin, R. Breastfeeding and IQ Growth from Toddlerhood through Adolescence. PLoS One. 2015;10(9):e0138676.

Included for systematic reviews not completed

2430 Vriezinga, S. L.,Auricchio, R.,Bravi, E.,Castillejo, G.,Chmielewska, A.,Crespo Escobar, P.,Kolacek, S.,Koletzko, S., Korponay-Szabo, I. Independent variable R.,Mummert, E.,Polanco, I.,Putter, H.,Ribes-Koninckx, C.,Shamir, R.,Szajewska, H.,Werkstetter, K.,Greco, L.,Gyimesi, J.,Hartman, C.,Hogen Esch, C.,Hopman, E.,Ivarsson, A.,Koltai, T.,Koning, F.,Martinez-Ojinaga, E.,te Marvelde, C.,Pavic, A.,Romanos, J.,Stoopman, E.,Villanacci, V.,Wijmenga, C., Troncone, R.,Mearin, M. L. Randomized feeding intervention in infants at high risk for celiac disease. N Engl J Med 2014;371(14):1304-15

2431 Wachs, T. D.,Kanashiro, H. C.,Gurkas, P. Intra-individual variability in infancy: structure, stability, and nutritional correlates. Dev Psychobiol. 2008;50(3):217-31

2432 Wadsworth, M. E.,Hardy, R. J.,Paul, A. A.,Marshall, S. F.,Cole, T. J. Leg and trunk length at 43 years in relation to childhood health, diet and family circumstances; evidence from the 1946 national birth cohort. Int J Epidemiol. 2002;31(2):383-90.

2433 Wagner, V.,von Stockhausen, H. B. The effect of feeding human milk and adapted milk formulae on serum lipid and lipoprotein levels in young infants. Eur J Pediatr. 1988;147(3):292-5.

2434 Wahlberg, J.,Vaarala, O.,Ludvigsson, J. Dietary risk factors for the emergence of type 1 diabetes-related autoantibodies in $21 / 2$ year-old Swedish children. Br J Nutr. 2006;95(3):603-8.

2435 Walker, W. A. Nucleotides and nutrition: role as dietary supplement. J Nutr. 1994;124(1 Suppl):121s-123s.

Independent variable

Dependent variable 

2008;93(4):292-6.

2438 Walter, T.,Pino, P.,Pizarro, F.,Lozoff, B. Prevention of iron-deficiency anemia: comparison of high- and low-iron formulas in term healthy infants

Independent variable after six months of life. J Pediatr. 1998;132(4):635-40.

2439 Walton, J. L.,Messer, L. B. Dental caries and fluorosis in breast-fed and bottle-fed children. Caries Res. 1981;15(2):124-37.

Study design

2440 Wan, A. K.,Seow, W. K.,Purdie, D. M.,Bird, P. S.,Walsh, L. J.,Tudehope, D. I. Oral colonization of Streptococcus mutans in six-month-old predentate infants. J Dent Res. 2001;80(12):2060-5.

2441 Wandera, A. Anticipatory guidance in infant oral health. J Mich Dent Assoc. 1998;80(9):28, 55-9.

Study design

Study design

2442 Wang, H.,Wang, A.,Wang, D.,Bright, A.,Sency, V.,Zhou, A.,Xin, B. Early growth and development impairment in patients with ganglioside GM3 synthase deficiency. Clin Genet. 2015.

Dependent variable,

Health status

2443 Wang, I. J.,Guo, Y. L.,Hwang, K. C.,Hsieh, W. S.,Chuang, Y. L.,Lin, S. J.,Chen, P. C. Genetic and environmental predictors for pediatric atopic Study design dermatitis. Acta Paediatrica Taiwanica. 2006;47(5):238-242.

2444 Wang, L.,Mamudu, H. M.,Alamian, A.,Anderson, J. L.,Brooks, B. Independent and joint effects of prenatal maternal smoking and maternal exposure to second-hand smoke on the development of adolescent obesity: a longitudinal study. J Paediatr Child Health. 2014;50(11):908-15

2445 Wang, X.,Xing, K. H.,Qi, J.,Guan, Y.,Zhang, J. Analysis of the relationship of insulin-like growth factor-1 to the growth velocity and feeding of healthy infants. Growth Horm IGF Res. 2013;23(6):215-9.

Independent variable

Included for

systematic reviews not completed

2446 Wang, Y, S Shen, Y. H. Wang, J. J., Yang, M. J.,Ding, S. W. Shi, Y. Y. Preliminary study on the blood glucose level in the exclusively breastfed newborn. J Trop Pediatr. 1994;40(3):187-8.

2447 Wang, Y. S.,Wu, S. Y. The effect of exclusive breastfeeding on development and incidence of infection in infants. J Hum Lact. 1996;12(1):27-30.

2448 Wang, Y.,Wang, A.,Donovan, S. M.,Teran-Garcia, M. Individual genetic variations related to satiety and appetite control increase risk of obesity in preschool-age children in the STRONG kids program. Hum Hered. 2013;75(2-4):152-9.

Independent variable

Independent variable

Study design,

Independent variable

2449 Warner, J. O. Food allergy in fully breast-fed infants. Clin Allergy. 1980;10(2):133-6.

Study design

2450 Warren, J. J.,Bishara, S. E. Duration of nutritive and nonnutritive sucking behaviors and their effects on the dental arches in the primary dentition. Am J Orthod Dentofacial Orthop. 2002;121(4):347-56.

2451 Warrington, S.,Storey, D. M. Comparative studies on Asian and Caucasian children. 2: Nutrition, feeding practices and health. Eur J Clin Nutr. 1988;42(1):69-79.

2452 Watase, S.,Mourino, A. P.,Tipton, G. A. An analysis of malocclusion in children with otitis media. Pediatr Dent. 1998;20(5):327-30.

udy design

Independent variable

2453 Watkinson, M. Delayed onset of weanling diarrhoea associated with high breast milk intake. Trans R Soc Trop Med Hyg. 1981;75(3):432-5.

Study design

Country 
2455 Watson, P. E.,McDonald, B. W. Subcutaneous body fat in pregnant New Zealand women: association with wheeze in their infants at 18 months. Matern Child Health J. 2013;17(5):959-67.

2456 Waylen, A.,Ford, T.,Goodman, R.,Samara, M.,Wolke, D. Can early intake of dietary omega-3 predict childhood externalizing behaviour?. Acta

Included for Paediatr. 2009;98(11):1805-8.

systematic reviews not completed

2457 Weber, F.,Woolridge, M. W.,Baum, J. D. An ultrasonographic study of the organisation of sucking and swallowing by newborn infants. Dev Med

Dependent variable Child Neurol. 1986;28(1):19-24.

2458 Weber, M.,Grote, V.,Closa-Monasterolo, R.,Escribano, J.,Langhendries, J. P.,Dain, E.,Giovannini, M.,Verduci, E.,Gruszfeld, D.,Socha, P.,Koletzko, B. Lower protein content in infant formula reduces BMI and obesity risk at school age: follow-up of a randomized trial. Am J Clin Nutr. 2014;99(5):1041-51.

2459 Weden, M. M.,Brownell, P.,Rendall, M. S. Prenatal, perinatal, early life, and sociodemographic factors underlying racial differences in the likelihood of high body mass index in early childhood. Am J Public Health. 2012;102(11):2057-67.

Included for

systematic reviews not completed

Included for

systematic reviews not completed

Study design

2460 Weerheijm, K. L.,Uyttendaele-Speybrouck, B. F.,Euwe, H. C.,Groen, H. J. Prolonged demand breast-feeding and nursing caries. Caries Res. 1998;32(1):46-50.

2461 Weggemann, T.,Brown, J. K.,Fulford, G. E.,Minns, R. A. A study of normal baby movements. Child Care Health Dev. 1987;13(1):41-58.

\section{Group size}

Dependent variable Wegienka, G.,Ownby, D. R.,Havstad, S.,Williams, L. K.,J
cohort. Ann Allergy Asthma Immunol. 2006;97(1):78-83.

2463 Wehby, G. L. Breastfeeding and child disability: a comparison of siblings from the United States. Econ Hum Biol. 2014;15:13-22.

Dependent variable

Study design

Study design Independent variable Health status

Study design

2466 Weinstein, P.,Domoto, P.,Wohlers, K.,Koday, M. Mexican-American parents with children at risk for baby bottle tooth decay: pilot study at a migrant farmworkers clinic. ASDC J Dent Child. 1992;59(5):376-83.

2467 Weisgerber, M. C.,Lye, P. S.,Nugent, M.,Li, S. H.,De Fouw, K.,Gedeit, R.,Simpson, P.,Gorelick, M. H. Relationship between caloric intake and length of hospital stay for infants with bronchiolitis. Hosp Pediatr. 2013;3(1):24-30.

2468 Welch, K. R.,Ariza, A. J.,Wieczorek, J. L.,Binns, H. J. Characteristics of obese children aged 1-4 years at a referral clinic. J Natl Med Assoc. 2008;100(8):884-91.
Health status

Study design 
2471 Welliver, R. C.,Wong, D. T.,Sun, M.,McCarthy, N. Parainfluenza virus bronchiolitis. Epidemiology and pathogenesis. Am J Dis Child. 1986;140(1):34-40.

Included for

systematic reviews not completed

2472 Wells, J. C.,Jonsdottir, O. H.,Hibberd, P. L.,Fewtrell, M. S., Thorsdottir, I.,Eaton, S.,Lucas, A.,Gunnlaugsson, G.,Kleinman, R. E. Randomized controlled trial of 4 compared with 6 mo of exclusive breastfeeding in Iceland: differences in breast-milk intake by stable-isotope probe. Am $\mathrm{J}$ Clin Nutr. 2012;96(1):73-9.

2473 Wells, J. C.,Stanley, M.,Laidlaw, A. S.,Day, J. M.,Davies, P. S. Energy intake in early infancy and childhood fatness. Int J Obes Relat Metab Disord. 1998;22(5):387-92.

2474 Wen, L. M.,Baur, L. A.,Rissel, C.,Simpson, J. M. A randomized controlled trial of an early intervention on childhood obesity: Results from the first 12 months. Obesity (Silver Spring, Md.). 2011;19:S67.

2475 Wen, L. M.,Baur, L. A.,Rissel, C.,Xu, H.,Simpson, J. M. Correlates of body mass index and overweight and obesity of children aged 2 years: findings from the healthy beginnings trial. Obesity (Silver Spring). 2014;22(7):1723-30.

2476 Wen, L. M.,Baur, L. A.,Simpson, J. M.,Rissel, C.,Wardle, K.,Flood, V. M. Healthy beginnings trial: The journey from the beginning. Obesity research \& clinical practice. 2013;7:e2.

2477 Wen, X.,Kong, K. L.,Eiden, R. D.,Sharma, N. N.,Xie, C. Sociodemographic differences and infant dietary patterns. Pediatrics.

Study design

Independent variable 2014;134(5):e1387-98

2478 Wen, X.,Shenassa, E. D.,Paradis, A. D. Maternal smoking, breastfeeding, and risk of childhood overweight: findings from a national cohort. Matern Child Health J. 2013;17(4):746-55.

Included for

systematic reviews not completed

2479 Weng, S. F.,Redsell, S. A.,Nathan, D.,Swift, J. A.,Yang, M.,Glazebrook, C. Estimating overweight risk in childhood from predictors during infancy. Pediatrics. 2013;132(2):e414-21.

Included for systematic reviews not completed

2480 Werneck, R. I.,Lawrence, H. P.,Kulkarni, G. V.,Locker, D. Early childhood caries and access to dental care among children of Portuguesespeaking immigrants in the city of Toronto. J Can Dent Assoc. 2008;74(9):805.

Study design

2481 Weston, J. Bottle feeding. Nursing (Lond). 1986;3(2):61-2.

Study design

2482 Wetzig, H.,Schulz, R.,Diez, U.,Herbarth, O.,Viehweg, B.,Borte, M. Associations between duration of breast-feeding, sensitization to hens' eggs and eczema infantum in one and two year old children at high risk of atopy. Int J Hyg Environ Health. 2000;203(1):17-21. 
2483 Weyermann, M.,Brenner, H.,Rothenbacher, D. Adipokines in human milk and risk of overweight in early childhood: a prospective cohort study. Epidemiology. 2007;18(6):722-9.

Included for systematic reviews not completed

Included for systematic reviews not completed

Study design Independent variable

Study design

Study design

Study design

Study design,

Independent variable

Study design

Group size

Group size

Included for

systematic reviews not

completed

Study design

Independent variable

Study design

Independent variable

Independent variable

2497 Whu, R.,Cirilo, G.,Wong, J.,Finkel, M. L.,Mendez, H. A.,Leggiadro, R. J. Risk factors for pediatric asthma in the South Bronx. J Asthma. 2007;44(10):855-9.

2498 Wi, C. I.,Park, M. A.,Juhn, Y. J. Development and initial testing of Asthma Predictive Index for a retrospective study: an exploratory study. J Asthma. 2015;52(2):183-90.
Study design 
2499 Wiberger, M.,Eiben, G.,Lissner, L.,Mehlig, K.,Papoutsou, S.,Hunsberger, M. Children consuming milk cereal drink are at increased risk for overweight: The IDEFICS Sweden study, on behalf of the IDEFICS Consortium. Scand J Public Health. 2014;42(6):518-24.

2500 Wickens, K.,Black, P.,Stanley, T. V.,Mitchell, E.,Barthow, C.,Fitzharris, P. A protective effect of Lactobacillus rhamnosus HN001 against eczema in the first 2 years of life persists to age 4 years. Clinical and Experimental Allergy. 2012;42(7):1071-9.

2501 Wickman, M.,Melen, E.,Berglind, N.,Lennart Nordvall, S.,Almqvist, C.,Kull, I.,Svartengren, M.,Pershagen, G. Strategies for preventing wheezing and asthma in small children. Allergy. 2003;58(8):742-7.

2502 Wigg, N. R.,Tong, S.,McMichael, A. J.,Baghurst, P. A.,Vimpani, G.,Roberts, R. Does breastfeeding at six months predict cognitive development?. Aust N Z J Public Health. 1998;22(2):232-6.

Independent variable

Independent variable

Included for

systematic reviews not

completed

2503 Wijga, A. H.,Scholtens, S.,Bemelmans, W. J. E.,Kerkhof, M.,Koppelman, G. H.,Brunekreef, B.,Smit, H. A. Diet, screen time, physical activity, and childhood overweight in the general population and in high risk subgroups: prospective analyses in the PIAMA birth cohort. Journal of Obesity. 2010:9p-9p 1p.

2504 Willatts, P.,Forsyth, S.,Agostoni, C.,Casaer, P.,Riva, E.,Boehm, G. Effects of long-chain PUFA supplementation in infant formula on cognitive function in later childhood. Am J Clin Nutr. 2013;98(2):536S-42S.

2505 Williams, D. M.,Martin, R. M.,Davey Smith, G.,Alberti, K. G.,Ben-Shlomo, Y.,McCarthy, A. Associations of infant nutrition with insulin resistance measures in early adulthood: evidence from the Barry-Caerphilly Growth (BCG) study. PLoS One. 2012;7(3):e34161.

2506 Williams, S. A.,Hargreaves, J. A. An inquiry into the effects of health related behaviour on dental health among young Asian children resident in a fluoridated city in Canada. Community Dent Health. 1990;7(4):413-20.

2507 Williams, S. M.,Taylor, B. J.,Ford, R. P.,Nelson, E. A. Growth velocity before sudden infant death. Arch Dis Child. 1990;65(12):1315-8.

Included for

systematic reviews not completed

Independent variable

Independent variable

Study design

Independent variable

2508 Williams, S. M.,Taylor, B. J.,Mitchell, E. A.,Scragg, R.,Ford, R. P.,Stewart, A. W. Sudden infant death syndrome in New Zealand: are risk scores useful? New Zealand National Cot Death Study Group. J Epidemiol Community Health. 1995;49(1):94-101.

Included for

systematic reviews not completed

2509 Williams, S. M.,Taylor, R. W.,Taylor, B. J. Secular changes in BMI and the associations between risk factors and BMI in children born 29 years apart. Pediatr Obes. 2013;8(1):21-30.

Included for

systematic reviews not completed

2510 Williamson, E.,Morley, R.,Lucas, A.,Carpenter, J. Propensity scores: from naive enthusiasm to intuitive understanding. Stat Methods Med Res. 2012;21(3):273-93.

Study design, Health status

2511 Williamson, I. G.,Dunleavey, J.,Robinson, D. Risk factors in otitis media with effusion. A 1 year case control study in 5-7 year old children. Fan Pract. 1994;11(3):271-4.

2512 Willows, N. D.,Dewailly, E., Gray-Donald, K. Anemia and iron status in Inuit infants from northern Quebec. Can J Public Health. 2000;91(6):40710.

Independent variable

Included for

systematic reviews not completed 
2514 Wingard, D. L.,Criqui, M. H.,Edelstein, S. L.,Tucker, J.,Tomlinson-Keasey, C.,Schwartz, J. E.,Friedman, H. S. Is breast-feeding in infancy Dependent variable associated with adult longevity?. Am J Public Health. 1994;84(9):1458-62.

2515 Wojcicki, J. M.,Young, M. B.,Perham-Hester, K. A.,de Schweinitz, P.,Gessner, B. D. Risk factors for obesity at age 3 in Alaskan children, including the role of beverage consumption: results from Alaska PRAMS 2005-2006 and its three-year follow-up survey, CUBS, 2008-2009. PLoS One. 2015;10(3):e0118711.

2516 Wolman, P. G. Feeding practices in infancy and prevalence of obesity in preschool children. J Am Diet Assoc. 1984;84(4):436-8.

Included for

systematic reviews not completed

Included for

systematic reviews not completed

2517 Wong, H. B. Child health in Singapore--past, present and future. Ann Acad Med Singapore. 1982;11(3):322-35.

Study design

2518 Wong, W. W.,Hachey, D. L.,Insull, W.,Opekun, A. R., Klein, P. D. Effect of dietary cholesterol on cholesterol synthesis in breast-fed and formulafed infants. J Lipid Res. 1993;34(8):1403-11.

2519 Woo, J. G., Guerrero, M. L.,Ruiz-Palacios, G. M.,Peng, Y. M.,Herbers, P. M.,Yao, W.,Ortega, H.,Davidson, B. S.,McMahon, R. J.,Morrow, A. L. Specific infant feeding practices do not consistently explain variation in anthropometry at age 1 year in urban United States, Mexico, and China cohorts. J Nutr. 2013;143(2):166-74.

2520 Wood, C. S.,Isaacs, P. C.,Jensen, M.,Hilton, H. G. Exclusively breast-fed infants: growth and caloric intake. Pediatr Nurs. $1988 ; 14(2): 117-24$.

2521 Wood, R.,Stockton, D.,Brown, H. Moving from a universal to targeted child health programme: which children receive enhanced care? A population-based study using routinely available data. Child Care Health Dev. 2013;39(6):772-81.

2522 Woodward, A.,Douglas, R. M.,Graham, N. M.,Miles, H. Acute respiratory illness in Adelaide children: breast feeding modifies the effect of passive smoking. J Epidemiol Community Health. 1990;44(3):224-30.

2523 Worobey, J. Effects of feeding method on infant temperament. Adv Child Dev Behav. 1993;24:37-61.

2524 Wray, J. Breastfeeding and primitive neonatal reflexes. Pract Midwife. 2008;11(5):53-6.

2525 Wright Mda, G.,Dutra de Oliveira, J. E. Is breast feeding the solution to the infant nutrition problem in underdeveloped countries?. Child Care Health Dev. 1986;12(6):359-68.

2526 Wright, A. L.,Bauer, M.,Naylor, A.,Sutcliffe, E.,Clark, L. Increasing breastfeeding rates to reduce infant illness at the community level. Pediatrics. 1998;101(5):837-44.

2527 Wright, A. L.,Holberg, C. J.,Martinez, F. D.,Morgan, W. J.,Taussig, L. M. Breast feeding and lower respiratory tract illness in the first year of life. Group Health Medical Associates. BMJ. 1989;299(6705):946-9. systematic reviews not completed

Study design

Included for systematic reviews not completed

Group size

Dependent variable Study design

Study design

Included for

systematic reviews not completed

Included for systematic reviews not completed 
2528 Wright, A. L.,Holberg, C. J.,Taussig, L. M.,Martinez, F. D. Factors influencing the relation of infant feeding to asthma and recurrent wheeze in childhood. Thorax. 2001;56(3):192-7.

2529 Wright, A. L.,Holberg, C. J.,Taussig, L. M.,Martinez, F. D.. Relationship of infant feeding to recurrent wheezing at age 6 years. Arch Pediatr Adolesc Med. 1995;149(7):758-63.

Included for

systematic reviews not completed

Independent variable Med Biol. 2000;478:131-7.

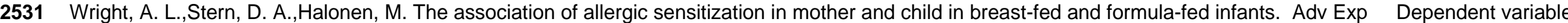
Med Biol. 2001:501:249-55.

2532 Wright, C. J.,Atkinson, F. S.,Ramalingam, N.,Buyken, A. E.,Brand-Miller, J. C. Effects of human milk and formula on postprandial glycaemia and Age insulinaemia. Eur J Clin Nutr. 2015;69(8):939-43.

2533 Wright, C. M.,Parkinson, K.,Scott, J. Breast-feeding in a UK urban context: who breast-feeds, for how long and does it matter?. Public Health Nutr. 2006;9(6):686-91.

2534 Wright, C. M.,Stone, D. H.,Parkinson, K. N. Undernutrition in British Haredi infants within the Gateshead Millennium cohort study. Arch Dis Child. 2010;95(8):630-3.

2535 Wright, C.,Lakshman, R.,Emmett, P.,Ong, K. K. Implications of adopting the WHO 2006 Child Growth Standard in the UK: two prospective cohort studies. Arch Dis Child. 2008;93(7):566-9.

2536 Wright, P. Development of feeding behaviour in early infancy: implications for obesity. Health Bull (Edinb). 1981;39(3):197-205.

Study design,

Independent variable

2537 Wu, T. C.,Huang, I. F.,Chen, Y. C.,Chen, P. H., Yang, L. Y.. Differences in serum biochemistry between breast-fed and formula-fed infants. J Chin Med Assoc. 2011;74(11):511-5.

$2538 \mathrm{Wu}$, T. C.,Hwang, B. Blood nutrient indices in breast and formula fed infants: amino acids metabolic responses. Zhonghua Min Guo Xiao Er Ke Yi Xue Hui Za Zhi. 1997;38(5):345-51.

2539 Wyne, A. H.,Adenubi, J. O.,Shalan, T.,Khan, N. Feeding and socioeconomic characteristics of nursing caries children in a Saudi population. Pediatr Dent. 1995;17(7):451-4.

2540 Xenellis, J.,Paschalidis, J.,Georgalas, C.,Davilis, D.,Tzagaroulakis, A.,Ferekidis, E. Factors influencing the presence of otitis media with effusion 16 months after initial diagnosis in a cohort of school-age children in rural Greece: a prospective study. Int J Pediatr Otorhinolaryngol. 2005;69(12):1641-7.
Included for systematic reviews not completed

\section{Included for}

systematic reviews not completed

Study design

Health status 
2543 Yakubov, R.,Nadir, E.,Stein, R.,Klein-Kremer, A. The Duration of Breastfeeding and Its Association with Metabolic Syndrome among Obese Study design Children. ScientificWorldJournal. 2015;2015:731319.

2544 Yalcin, S. S.,Hizli, S.,Yurdakok, K.,Ozmert, E. Risk factors for hospitalization in children with acute diarrhea: a case control study. Turk J Pediatr. 2005;47(4):339-42.

2545 Yalcin, S. S.,Turul, B.,Cetinkaya, S.,Cakir, B.,Yilmaz, A. Effect of total attending period on infection episode rate in a child-care center. Pediatr Int. 2004;46(5):555-60

Health status

Included fo

systematic reviews not completed

2546 Yamakawa, M.,Yorifuji, T.,Inoue, S.,Kato, T.,Doi, H. Breastfeeding and obesity among schoolchildren: a nationwide longitudinal survey in Japan. JAMA Pediatr. 2013;167(10):919-25.

Included for systematic reviews not completed

2547 Yamakawa, M.,Yorifuji, T.,Kato, T.,Inoue, S.,Tokinobu, A.,Tsuda, T.,Doi, H. Long-Term Effects of Breastfeeding on Children's Hospitalization for Respiratory Tract Infections and Diarrhea in Early Childhood in Japan. Matern Child Health J. 2015;19(9):1956-65.

Included for systematic reviews not completed

2548 Yamakawa, M.,Yorifuji, T.,Kato, T.,Yamauchi, Y.,Doi, H. Breast-feeding and hospitalization for asthma in early childhood: a nationwide longitudinal survey in Japan. Public Health Nutr. 2015;18(10):1756-61.

2549 Yamauchi, Y.,Yamanouchi, I. The relationship between rooming-in/not rooming-in and breast-feeding variables. Acta Paediatr Scand. 1990;79(11):1017-22.

2550 Yamauchi, Y.,Yamanouchi, I. The relationship between rooming-in/not rooming-in and breastfeeding variables. Breastfeeding Review. 1992;2(5):238-241 4p.

2551 Yamborisut, U.,Kosulwat, V.,Chittchang, U.,Wimonpeerapattana, W.,Suthutvoravut, U. Factors associated with dual form of malnutrition in school children in Nakhon Pathom and Bangkok. J Med Assoc Thai. 2006;89(7):1012-23.

2552 Yang, S.,Fombonne, E.,Kramer, M. S. Duration of gestation, size at birth and later childhood behaviour. Paediatr Perinat Epidemiol 2011;25(4):377-87.

2553 Yang, S.,Platt, R. W.,Dahhou, M.,Kramer, M. S. Do population-based interventions widen or narrow socioeconomic inequalities? The case of breastfeeding promotion. Int J Epidemiol. 2014;43(4):1284-92.

Independent variable

Independent variable

Independent variable

Study design

Independent variable

Included for

systematic reviews not completed

2554 Ye, M.,Mandhane, P. J.,Senthilselvan, A. Association of breastfeeding with asthma in young Aboriginal children in Canada. Can Respir J. 2012;19(6):361-6.

2555 Ye, W.,Feng, X. P.,Liu, Y. L. Epidemiological study of the risk factors of rampant caries in Shanghai children. Chin J Dent Res. 1999;2(2):58-62. Study design 
2557 Yeung, K. A.,Taylor, T.,Scheimann, A.,Carvalho, R.,Reinhardt, E.,Girolami, P.,Wood, R. The Prevalence of Food Allergies in Children Referred Health status to a Multidisciplinary Feeding Program. Clin Pediatr (Phila). 2015;54(11):1081-6.

2558 Yi, M. J.,Sun, D. F.,Zhou, X. B. Relationship between infant breast feeding and simple obesity in preschool children: A case-control study.

Chinese Journal of Clinical Rehabilitation. 2003;7(30):4088-4089.

2559 Yi, M. J.,Sun, M. H.,Liu, F.,Liu, Y. Association between infant breastfeeding and temperamental characteristics development in children aged 4-5 Study design years. Journal of Clinical Rehabilitative Tissue Engineering Research. 2007;11(30):6100-6102.

2560 Yildirim, Ş,Binnetoğlu, F. K.,Aylanç, H.,Battal, F.,Tekin, M.,Kaymaz, N.,Topaloğlu, N.,A§lk, Z. Effect of infant feeding on epicardial fat thickness in normal weighted children. Anatolian Journal of Clinical Investigation. 2015;9(3):92-97.

2561 Yimyaem, P.,Chongsrisawat, V.,Vivatvakin, B.,Wisedopas, N. Gastrointestinal manifestations of cow's milk protein allergy during the first year of Study design life. J Med Assoc Thai. 2003;86(2):116-23.

2562 Yin, J.,Quinn, S.,Dwyer, T.,Ponsonby, A. L.,Jones, G. Maternal diet, breastfeeding and adolescent body composition: a 16-year prospective study. Eur J Clin Nutr. 2012;66(12):1329-34.

2563 Yip R,Parvanta I,Scanlon K,Borland EW,Russell CM,Trowbridge FL. Pediatric nutrition surveillance system--United States, 1980-1991. MMWR CDC Surveill Summ. 1992;41:1-24.

2564 Yiş, U.,Öztürk, Y.,Şişman, A. R.,Uysal, S.,Soylu Ö, B.,Büyükgebiz, B. The relation of serum ghrelin, leptin and insulin levels to the growth patterns and feeding characteristics in breast-fed versus formula-fed infants. Turkish Journal of Pediatrics. 2010;52(1):35-41.

2565 Yoneyama, K.,Nagata, H.,Asano, H. Growth of Japanese breast-fed and bottle-fed infants from birth to 20 months. Ann Hum Biol. 1994;21(6):597-608.

2566 Yonezu, T.,Ushida, N.,Yakushiji, M. Longitudinal study of prolonged breast- or bottle-feeding on dental caries in Japanese children. Bull Tokyo Dent Coll. 2006;47(4):157-60.

2567 Yonezu, T.,Yotsuya, K.,Yakushiji, M. Characteristics of breast-fed children with nursing caries. Bull Tokyo Dent Coll. 2006;47(4):161-5.

2568 Yoon, H. S.,Shin, Y. J.,Ki, M. Risk factors for neonatal infections in full-term babies in South Korea. Yonsei Medical Journal. 2008;49(4):530536.

2569 Yorifuji, T.,Kubo, T.,Yamakawa, M.,Kato, T.,Inoue, S.,Tokinobu, A.,Doi, H. Breastfeeding and behavioral development: a nationwide longitudinal survey in Japan. J Pediatr. 2014;164(5):1019-1025 e3.
Study design, Health

status

Study design

ncluded for systematic reviews not completed

Independent variable, Dependent variable

Group size

Independent variable

Included for

systematic reviews not completed

Study design, Independent variable

Dependent variable

Included for

systematic reviews not completed 

Pediatrics. 1982;69(2):169-75.

2571 Young, R. J.,Antonson, D. L.,Ferguson, P. W.,Murray, N. D.,Merkel, K.,Moore, T. E. Neonatal and infant feeding: effect on bone density at 4 years. J Pediatr Gastroenterol Nutr. 2005;41(1):88-93.

Included for systematic reviews not completed

2572 Young, S.,O'Keeffe, P. T.,Arnott, J.,Landau, L. I. Lung function, airway responsiveness, and respiratory symptoms before and after bronchiolitis. Arch Dis Child. 1995;72(1):16-24

2573 Yu, C.,Binns, C. W.,Lee, A. H. Comparison of breastfeeding rates and health outcomes for infants receiving care from hospital outpatient clinic and community health centres in China. J Child Health Care. 2015

2574 Yu, L. X.,Tao, Y.,Qiu, R. M.,Zhou, Y.,Zhi, Q. H.,Lin, H. C. Genetic polymorphisms of the sortase A gene and social-behavioural factors associated with caries in children: a case-control study. BMC Oral Health. 2015;15:54.

2575 Yuksel, H.,Sakar, A.,Dinc, G.,Yilmaz, O.,Gozmen, S.,Yorgancioglu, A.,Ozcan, C. The frequency of wheezing phenotypes and risk factors for persistence in aegean region of Turkey. J Asthma. 2007;44(2):89-93.

2576 Yung, J.,Yuen, J. W. M.,Ou, Y.,Loke, A. Y. Factors associated with atopy in toddlers: A case-control study. International Journal of Environmental Research and Public Health. 2015;12(3):2501-2520.

2577 Yurdakok, K.,Ozmert, E.,Yalcin, S. S. Physical examination of breast-fed infants. Arch Pediatr Adolesc Med. 1997;151(4):429-30.

Study design,

Independent variable

Group size

Included for

systematic reviews not completed

Study design

Study design

Study design

Study design

Included for systematic reviews not completed

Study design

2579 Zadzinska E,Sitek A,Rosset I. Relationship between pre-natal factors, the perinatal environment, motor development in the first year of life and the timing of first deciduous tooth emergence. Ann Hum Biol. 2016;43:25-33.

2580 Zaini, M. Z.,Lim, C. T.,Low, W. Y.,Harun, F. Factors affecting nutritional status of Malaysian primary school children. Asia Pac J Public Health. 2005;17(2):71-80.

2581 Zamora, G.,Lutter, C. K.,Pena-Rosas, J. P. Using an equity lens in the implementation of interventions to protect, promote, and support optimal breastfeeding practices. J Hum Lact. 2015;31(1):21-5.

2582 Zarnani, A. H.,Modarres, Sh,Jadali, F.,Sabahi, F.,Moazzeni, S. M.,Vazirian, F. Role of rotaviruses in children with acute diarrhea in Tehran, Iran. Journal of Clinical Virology. 2004;29(3):189-193.

2583 Zedan, M.,Nasef, N.,El-Bayoumy, M.,El-Assmy, M.,Attia, G.,Zedan, M.,AlWakeel, A.,Kandil, S.,Laimon, W.,Fouda, A. Does decline of lung function in wheezy infants justify the early start of controller medications?. Indian J Pediatr. 2012;79(9):1176-80.

2584 Zell, B. L. Breastfeeding as a community health imperative. Breastfeed Med. 2011;6:303-4.
Study design

Study design,

Dependent variable

Study design, Health status

Country 
2587 Zhang, J.,Jiang, J.,Himes, J. H.,Zhang, J.,Liu, G.,Huang, X.,Guo, Y.,Shi, J.,Shi, S. Determinants of high weight gain and high BMI status in the first three months in urban Chinese infants. Am J Hum Biol. 2012;24(5):633-9.

Included for

systematic reviews not completed

2588 Zhang, S.,Liu, J.,Lo, E. C.,Chu, C. H. Dental caries status of Dai preschool children in Yunnan Province, China. BMC Oral Health. 2013;13:68.

Study design,

Independent variable

2589 Zheng, J. S.,Liu, H.,Li, J.,Chen, Y.,Wei, C.,Shen, G.,Zhu, S.,Chen, H.,Zhao, Y. M.,Huang, T.,Li, D. Exclusive breastfeeding is inversely associated with risk of childhood overweight in a large Chinese cohort. J Nutr. 2014;144(9):1454-9.

Included for

systematic reviews not completed

2590 Zheng, W.,Suzuki, K., Shinohara, R.,Sato, M.,Yokomichi, H.,Yamagata, Z. Maternal smoking during pregnancy and growth in infancy: a Independent variable covariance structure analysis. J Epidemiol. 2015;25(1):44-9.

2591 Zhong, B. L.,Ding, J.,Chen, H. H.,Li, Y.,Xu, H. M.,Tong, J.,Wang, A. Q., Tang, G. Z.,Zhu, J. S., Yang, D. Q., Liu, B., Wang, Q., Cheng, W. F., Yin E.,Xu, M. J.,Zhang, T.,Hu, T. M.,Feng, X. W.,Li, H.,Dan, T. Q.,Cheng, G. M.,Zhang, J. F.,Li, H. J.,Zhu, J. H. Depressive disorders among children in the transforming China: an epidemiological survey of prevalence, correlates, and service use. Depress Anxiety. 2013;30(9):881-92.

2592 Zhou, S. J.,Baghurst, P.,Gibson, R. A.,Makrides, M. Home environment, not duration of breast-feeding, predicts intelligence quotient of children at four years. Nutrition. 2007;23(3):236-41.

Study design

Included for

systematic reviews not completed

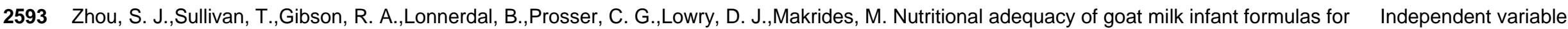
term infants: a double-blind randomised controlled trial. Br J Nutr. 2014;111(9):1641-51.

2594 Zhou, S. J.,Sullivan, T.,Gibson, R. A.,Makrides, M. How does goat milk infant formula compare to cow milk formula? A randomised controlled trial [conference abstract]. Journal of pediatric gastroenterology and nutrition. 2011;52:E208-e209.

Study design

2595 Ziajka, S.,Zbikowski, Z. Characterization and properties of infant milk formulae with addition of enzymatically digested casein. Nahrung. 1986;30(3-4):413-4.

2596 Ziegler, A. G.,Schmid, S.,Huber, D.,Hummel, M.,Bonifacio, E. Early infant feeding and risk of developing type 1 diabetes-associated autoantibodies. JAMA. 2003;290(13):1721-8.

2597 Ziegler, E. E.,Fields, D. A.,Chernausek, S. D.,Steenhout, P.,Grathwohl, D.,Jeter, J. M.,Nelson, S. E.,Haschke, F. Adequacy of Infant Formula With Protein Content of $1.6 \mathrm{~g} / 100 \mathrm{kcal}$ for Infants Between 3 and 12 Months. J Pediatr Gastroenterol Nutr. 2015;61(5):596-603.

2598 Ziegler, E. E.,Jiang, T.,Romero, E.,Vinco, A.,Frantz, J. A.,Nelson, S. E. Cow's milk and intestinal blood loss in late infancy. J Pediatr. 1999;135(6):720-6.

Study design,

Independent variable

Dependent variable

Independent variable

Independent variable Dependent variable 
2600 Ziegler, E.,Vanderhoof, J. A.,Petschow, B.,Mitmesser, S. H.,Stolz, S. I.,Harris, C. L.,Berseth, C. L. Term infants fed formula supplemented with selected blends of prebiotics grow normally and have soft stools similar to those reported for breast-fed infants. J Pediatr Gastroenterol Nutr. 2007;44(3):359-64

2601 Zielhuis, G. A.,Heuvelmans-Heinen, E. W.,Rach, G. H.,van den Broek, P. Environmental risk factors for otitis media with effusion in preschool children. Scand J Prim Health Care. 1989;7(1):33-8.

Included for

systematic reviews not completed

2602 Zive, M. M.,McKay, H.,Frank-Spohrer, G. C.,Broyles, S. L.,Nelson, J. A.,Nader, P. R. Infant-feeding practices and adiposity in 4-y-old Anglo- and Study design Mexican-Americans. Am J Clin Nutr. 1992;55(6):1104-8. Odontol Bras. 2003;17(2):151-5

2604 Zoppi, G.,Ferrarini, G.,Rigolin, F.,Bogaerts, H.,Andre, F. E. Response to RIT 4237 oral rotavirus vaccine in breast-fed and formula-fed infants. Helv Paediatr Acta. 1986;41(3):203-8.

2605 Zoppi, G.,Mantovanelli, F.,Gobio Casali, L.,Astolfi, R.,Cecchettin, M. Effects of the composition and caloric value of infant formulas on intake and hormone levels. J Pediatr Gastroenterol Nutr. 1986;5(5):756-61.

2606 Zuccotti, G.,Vigano, A.,Cafarelli, L.,Pivetti, V.,Pogliani, L.,Puzzovio, M.,Mora, S. Longitudinal changes of bone ultrasound measurements in healthy infants during the first year of life: influence of gender and type of feeding. Calcif Tissue Int. 2011;89(4):312-7. 